Work Papers of the Summer

Institute of Linguistics, University

of North Dakota Session

\title{
Writing Gojri: Linguistic and sociolinguistic constraints on a standardized orthography for the Gujars of South Asia
}

Wayne E. Losey

SIL-UND

How does access to this work benefit you? Let us know!

Follow this and additional works at: https://commons.und.edu/sil-work-papers

Part of the Linguistics Commons

\author{
Recommended Citation \\ Losey, Wayne E. (2002) "Writing Gojri: Linguistic and sociolinguistic constraints on a standardized \\ orthography for the Gujars of South Asia," Work Papers of the Summer Institute of Linguistics, University \\ of North Dakota Session: Vol. 46, Article 3. \\ DOI: 10.31356/silwp.vol46.03 \\ Available at: https://commons.und.edu/sil-work-papers/vol46/iss1/3
}

This Thesis is brought to you for free and open access by UND Scholarly Commons. It has been accepted for inclusion in Work Papers of the Summer Institute of Linguistics, University of North Dakota Session by an authorized editor of UND Scholarly Commons. For more information, please contact und.commons@library.und.edu. 


\title{
WRITING GOJRI: \\ LINGUISTIC AND SOCIOLINGUISTIC CONSTRAINTS ON A STANDARDIZED \\ ORTHOGRAPHY FOR THE GUJARS OF SOUTH ASIA
}

by

\author{
Wayne E. Losey \\ Bachelor of Arts, Wheaton College, 1989 \\ Master of Divinity, Denver Seminary, 1996
}

\author{
A Thesis \\ Submitted to the Graduate Faculty \\ of the \\ University of North Dakota \\ in partial fulfillment of the requirements \\ for the degree of \\ Master of Arts
}

Grand Forks, North Dakota

December

2002 
This thesis, submitted by Wayne E. Losey in partial fulfillment of the requirements for the Degree of Master of Arts from the University of North Dakota, has been read by the Faculty Advisory Committee under whom the work has been done and is hereby approved.

Joan Baart

S. H. Levinsohn

Mark E. Karan

This thesis meets the standards for appearance, conforms to the style and format requirements of the Graduate School of the University of North Dakota, and is hereby approved.

Dean of the Graduate School

Date 


\section{PERMISSION}

Title Writing Gojri: Linguistic and Sociolinguistic Constraints on a Standardized Orthography for the Gujars of South Asia

Department Linguistics

Degree Master of Arts

In presenting this thesis in partial fulfillment of the requirements for a graduate degree from the University of North Dakota, I agree that the library of this University shall make it freely available for inspection. I further agree that permission for extensive copying for scholarly purposes may be granted by the professor who supervised my thesis work or, in his absence, by the chairperson of the department or the dean of the Graduate School. It is understood that any copying or publication or other use of this thesis or part thereof for financial gain shall not be allowed without my written permission. It is also understood that due recognition shall be given to me and to the University of North Dakota in any scholarly use which may be made of any material in my thesis.

Signature

Date 


\section{TABLE OF CONTENTS}

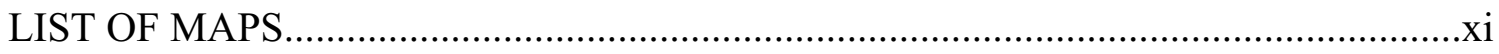

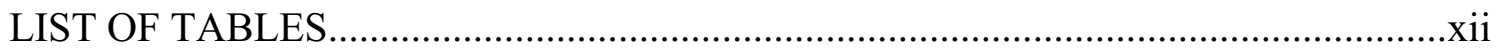

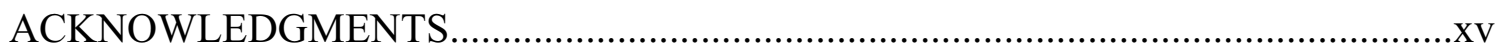

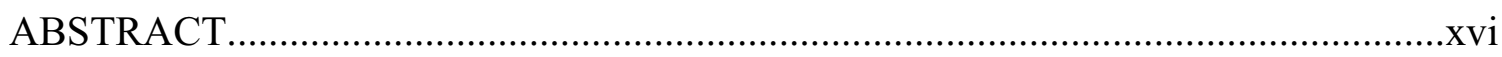

\section{CHAPTER}

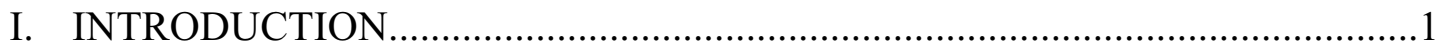

1.1 Gujars and the Gojri Language...................................................................

1.1.1 Language Classification.......................................................................1

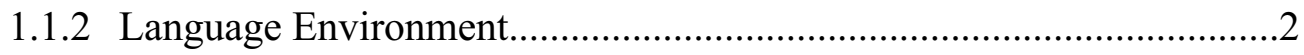

1.1.3 Language Development.....................................................................

1.2 Socioeconomic Conditions and the Literacy Situation....................................6

1.3 History of Research into Gojri................................................................9

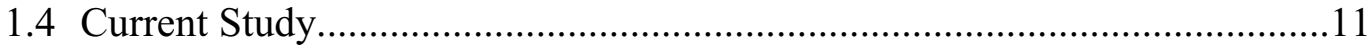

1.4.1 Purpose

1.4.2 Data Collection and Analysis...........................................................12

1.4.3 Overview of Remaining Chapters.......................................................14

II. COMPARATIVE GOJRI PHONOLOGY AND THE GOJRI SCRIPT.............17

2.1 Gojri Consonant Phonemes..........................................................................17

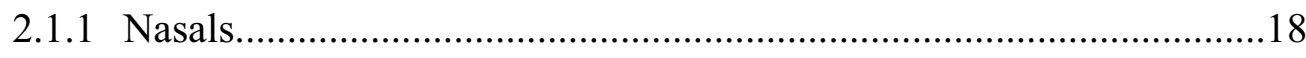

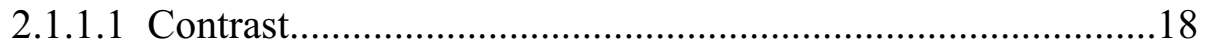

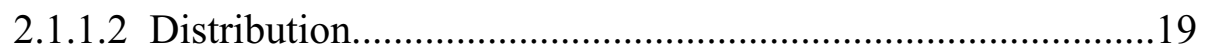


2.1.1.3 Variation....................................................................19

2.1.2 Laterals and Flaps.......................................................................20

2.1.2.1 Contrast.......................................................................20

2.1.2.2 Distribution............................................................21

2.1.2.3 Variation.........................................................................22

2.1.3 Labial Area Consonants.................................................................22

2.1.3.1 Contrast...................................................................22

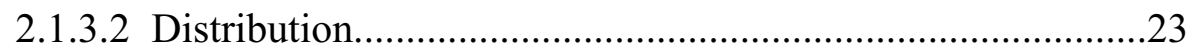

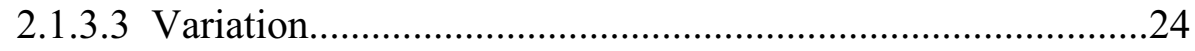

2.1.4 General Dental Area Consonants................................................26

2.1.4.1 Contrast..................................................................27

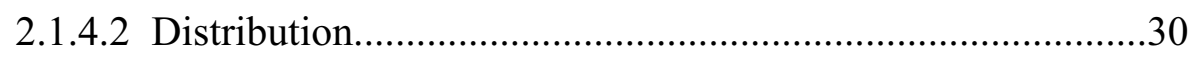

2.1.4.3 Variation....................................................................... 31

2.1.5 Velar Area Stops and Fricatives..................................................... 31

2.1.5.1 Contrast........................................................................ 31

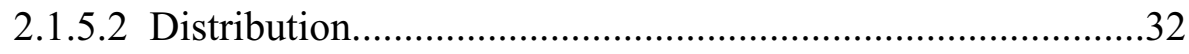

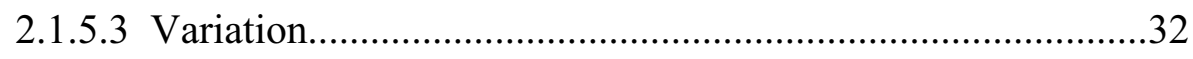

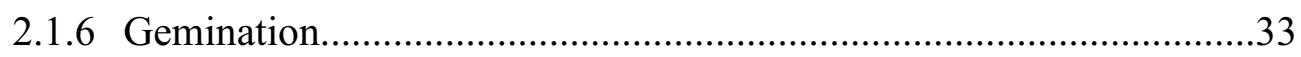

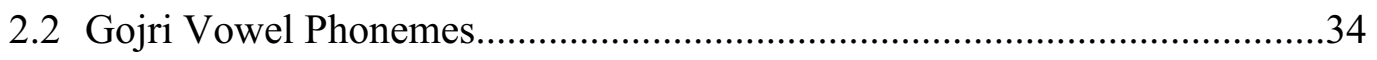

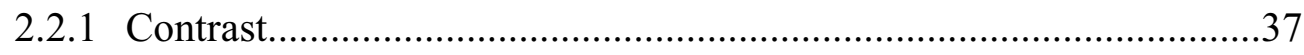

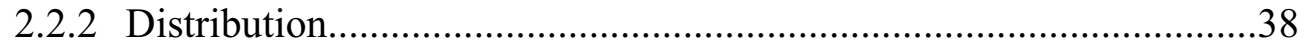

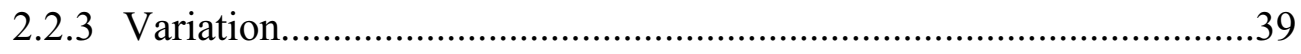

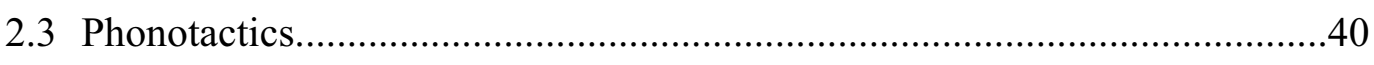

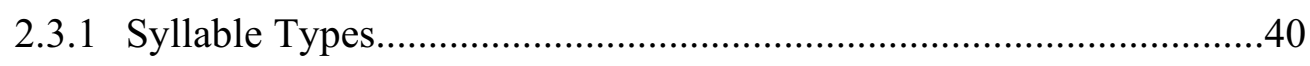


2.3.2 Consonant Clusters

2.3.3 Vowel Sequences (Hiatus) ...............................................................43

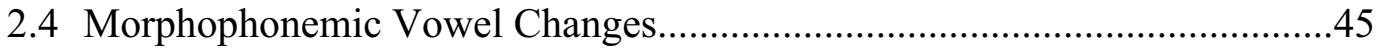

2.4.1 Vowel Changes with Verbal Suffixation............................................45

2.4.1.1 Vowel Changes with the Causative Suffix $/-\bar{a} / . \ldots \ldots \ldots \ldots \ldots \ldots \ldots . . . . . . . .46$

2.4.1.2 Vowel Changes with Vocalic Tense, Aspect, and Agreement Suffixes.

2.4.2 Vowel Changes with Nominal Suffixation.........................................49

2.5 Other Processes......................................................................................

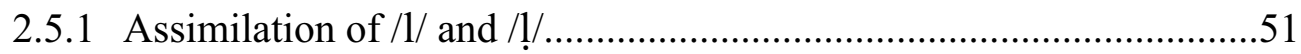

2.5.2 Assimilation of the Dative Postposition /nā/ to the Infinitive............51

2.5.3 Avoidance of Cluster /mn/ by Replacement of /n/........................51

2.5.4 Replacement of the Infinitive Suffix /-ṇ/ with /-n/.........................52

2.5.5 Voicing Assimilation of the Genitive Postposition $/ \mathrm{k}-/ \ldots \ldots \ldots \ldots \ldots \ldots . . .52$

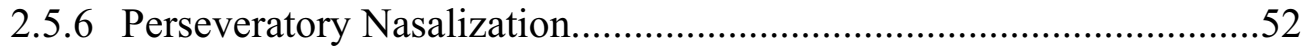

2.6 Representation of Gojri Phonemes in the Gojri Script.................................53

2.6.1 Representation of Consonant Phonemes.......................................53

2.6.1.1 Representation of the Gojri Retroflexes $/ \mathrm{n} /$ and $/ 1 / \ldots \ldots \ldots \ldots . . .54$

2.6.1.2 Representation of the Geminated Retroflex Lateral /1! /.........57

2.6.1.3 Representation of the Glides /w/ and /y/..........................56

2.6.1.4 Representation of Nasalized Vowels and Nasal Clusters...... 58

2.6.1.5 Phoneme/Grapheme Associations for Gojri Consonants.......59

2.6.2 Representation of Vowel Phonemes..............................................60

III. GOJRI TONE AND ITS REPRESENTATION ..............................................62 


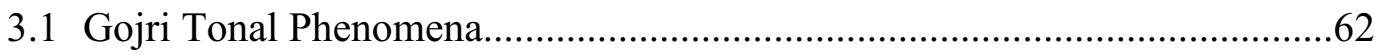

3.1.1 Phonetic Pitch Contrasts....................................................................62

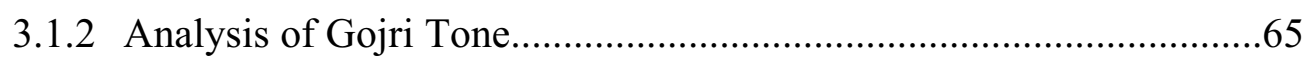

3.1.2.1 Tone and the Stressed Syllable.................................................65

3.1.2.2 Composition of Contour Tones.................................................66

3.1.2.3 Low-Tone Causatives of High Tone Verbs.............................67

3.1.2.4 Low Tone Related to Loss of Initial Aspiration......................70

3.1.2.5 Summary of Analysis................................................................

3.1.2.6 Other Low-Tone Words.........................................................75

3.1.2.7 Other High-Tone Words..........................................................78

3.1.2.8 Low Tone Co-occurring with Aspiration.................................80

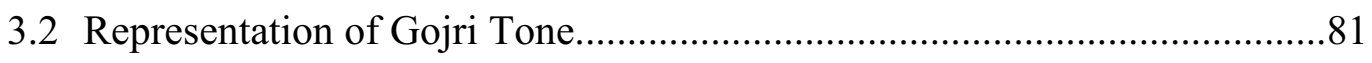

3.2.1 Tone Marking in Orthography Design.................................................81

3.2.2 Evaluation of Conventions In-Use...................................................

3.2.2.1 Writing of Low Tone Occurring with Initial $/ \mathrm{h} /$ in

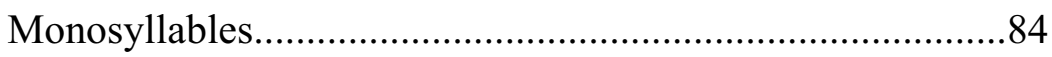

3.2.2.2 Surface Approach to Low Tone Related to Loss of Initial

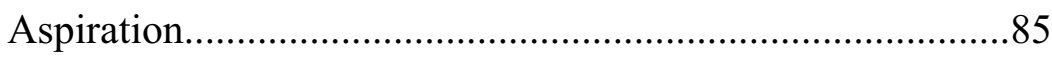

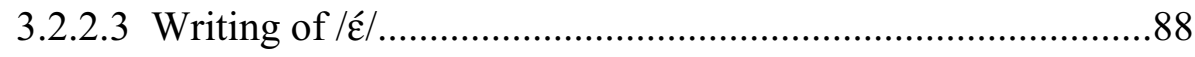

3.2.2.4 Iconic Approach to Low Tone Related to Loss of Initial

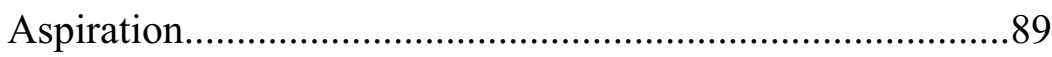

3.2.2.5 Writing of High-Tone Words (Other than / $\mid \mathfrak{\varepsilon} /$ - Type)............92

3.2.2.6 Writing of Other Low-Tone Words.........................................96

3.2.3 Evaluation Summary........................................................................101 
IV. COMPARATIVE GOJRI MORPHOSYNTAX.......................................... 105

4.1 Noun-Phrase Constituents and Operations..................................................105

4.1.1 The Structure of Nouns and Noun Phrases........................................105

4.1.1.1 Marked and Unmarked Nouns..............................................105

4.1.1.2 The Noun Phrase...................................................................107

4.1.2 Gender and Number.....................................................................108

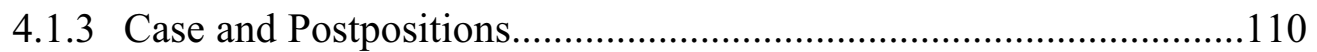

4.1.3.1 Layer I: Case-Marking Suffixes..........................................110

4.1.3.2 Layer II: Postpositions Mediated by Oblique Case..............117

4.1.3.2.1 Primary or Case-Marking Postpositions..............117

4.1.3.2.2 Other Layer II Postpositions..................................121

4.1.3.3 Layer III Postpositions..........................................................124

4.1.3.3.1 Postpositions Mediated by the Genitive-Locative

Postposition $/ \mathrm{k} \varepsilon /$............................................... 124

4.1.3.3.2 Postpositions Mediated by the Ablative

Postposition /te/...............................................128

4.1.4 Pronouns and Demonstratives............................................................128

4.1.5 Adjectives...............................................................................135

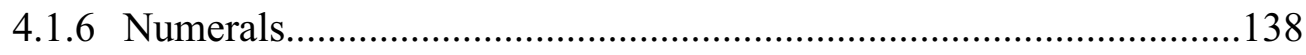

4.2 Verb-Phrase Constituents and Operations..................................................142

4.2.1 Verbal Forms and Categories.............................................................142

4.2.1.1 Structure of Gojri Finite Verbal Constructions......................142

4.2.1.2 Tense, Aspect, Mood, and Finite Verbal Constructions.......145 
4.2.1.2.1 Finite Verbal Constructions Based on Forms Unmarked for Aspect.

4.2.1.2.2 Finite Verbal Constructions Based on Forms Marked for Aspect. 152

4.2.1.2.3 Verbal Inflections. 155

4.2.1.2.4 Finite Verbal Constructions Involving Tense

Auxiliaries 156

4.2.1.2.5 Finite Verbal Constructions Involving Other Auxiliaries. 160

4.2.1.3 Dialect-specific Finite Verbal Constructions.........................168

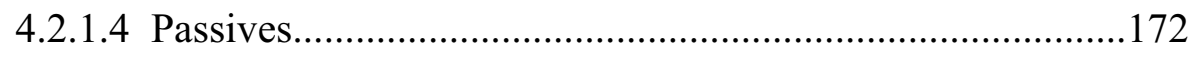

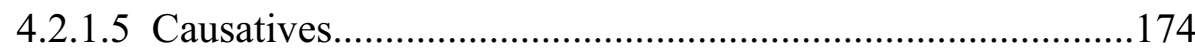

4.2.1.6 Conjunct Verbs..................................................................176

4.2.1.7 Non-finite Verb Forms........................................................176

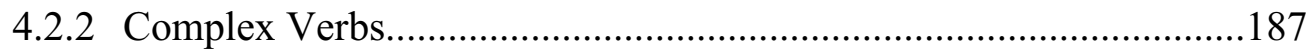

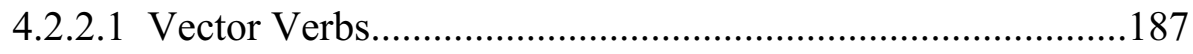

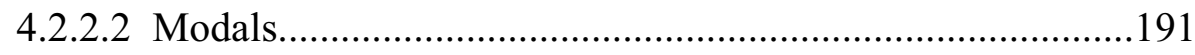

4.2.2.3 Secondary Aspectuals............................................................193

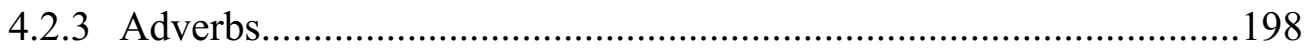

4.2.3.1 Other Adverbs of Manner......................................................199

4.2.3.2 Other Adverbs of Time........................................................200

4.2.3.3 Other Adverbs of Place and Direction....................................200

4.2.3.4 Other Adverbs of Degree.......................................................201

4.2.3.5 Epistemic Adverbs..............................................................201 
V. TOWARD STANDARDIZED GOJRI SPELLINGS AND LITERATURE.....202

5.1 Dialectal Variation and the Standardization of Gojri.................................202

5.2 Approaches to Spelling: Theoretical Considerations...............................204

5.2.1 From Phonology.................................................................205

5.2.2 From Reading Theory................................................................206

5.2.3 Simons' Principles of Multidalectal Orthography Design................208

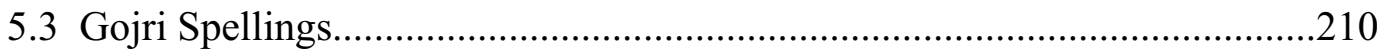

5.3.1 Basing a Word's Spelling on its Isolation Form..............................210

5.3.2 Consistent Representation of Morphological Affixes.....................211

5.3.3 Words Involving Perseveratory Nasalization..............................211

5.3.4 Stems Ending in Nasalized Vowels............................................212

5.3.5 Constraints on the Employment of Vowel Diacritics......................212

5.3.6 Constraints on the Adoption of Urdu Spellings............................213

5.3.7 Pronouns and Demonstratives...................................................215

5.3.8 Western Present Auxiliary and Inflections of /hò-/ 'be' ...................223

5.3.9 Treatment of Loan Words..........................................................224

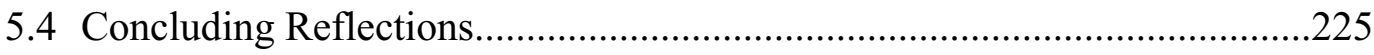

\section{APPENDICES}

APPENDIX A: ABBREVIATIONS AND DATA PRESENTATION.............227

APPENDIX B: 'BAKARWAL' GOJRI PHONETIC WORD LISTS...............230

APPENDIX C: GOJRI VERBAL PARADIGMS.........................................245

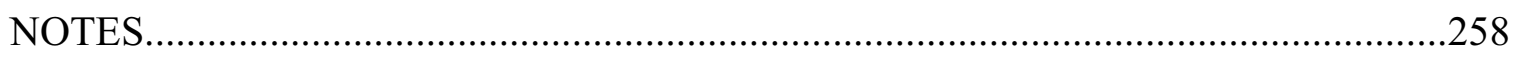

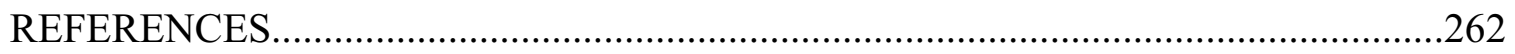




\section{LIST OF MAPS}

$\begin{array}{lll}\text { Map } & \text { Page }\end{array}$

1. Kashmir and surrounding areas, showing inset for Map 2.....................................15

2. Hazara region, Pakistan; districts Batagram, Mansehra, Abbottabad, Haripur........ 16 


\section{LIST OF TABLES}

Table

Page

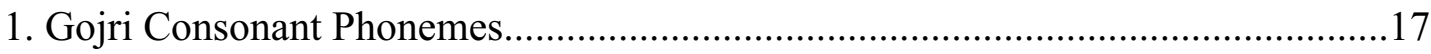

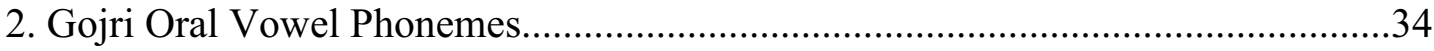

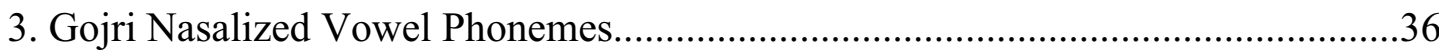

4. Morphophonemic Changes for Stems Ending in /ع́/: /ré/ 'stay'............................49

5. Orthographic Differentiation of Medial /y/ and /yy/, Final /y/ and /e/...................58

6. Phoneme/Grapheme Associations for Gojri Consonants.....................................59

7. Phoneme/Grapheme Associations for Gojri Vowels .........................................61

8. Urdu-based Conventions for Representing Lexical L in Gojri ............................103

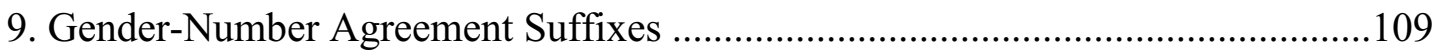

10. Inflection of Marked Animate Nouns: /bač-/ 'child' .......................................116

11. Inflection of Marked Inanimate Nouns: /dèāṛ-/ (/dì̄āṛ-/) ‘day’ ........................116

12. Inflection of Unmarked Animate Nouns: /pūt/ 'son', /béṇ/ 'sister' ...................116

13. First and Second Person Pronouns/Possessive Adjectives...............................129

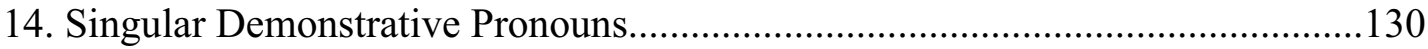

15. Plural Demonstrative Pronouns ................................................................... 131

16. Indefinite Pronouns, with Corresponding Interrogative Pronouns.......................133

17. Relative Pronouns, with Corresponding Interrogative Pronouns ......................133

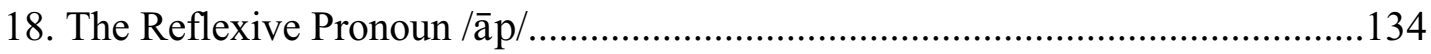


19. Interrogative, Relative, and Demonstrative Adjective Sets.

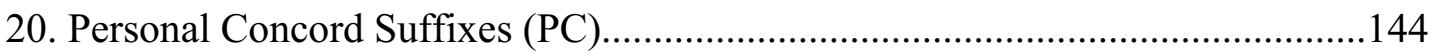

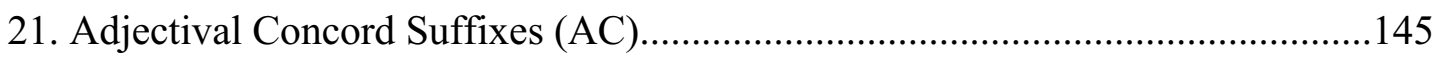

22. Primary Verbal Constructions.........................................................................146

23. Gojri Verb Forms Unmarked for Aspect: /sad-/ ‘call'..........................................155

24. Gojri Verb Forms Marked for Aspect: /sad-/ 'call'.............................................156

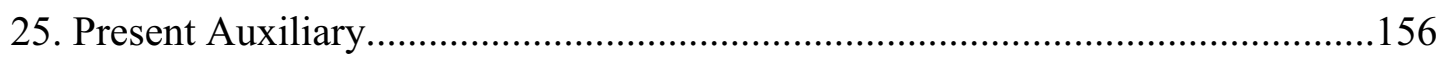

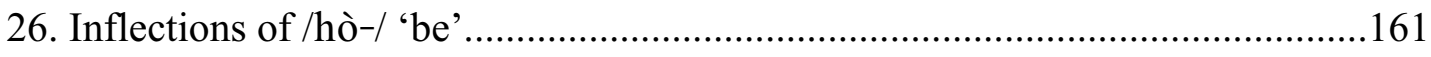

27. Interrogative/Relative/Proximate/Distal Adverb Sets..........................................199

28. Spellings for First and Second Person Nominative Pronouns...............................215

29. Spellings for Third Person Nominative Demonstrative Pronouns.......................216

30. Spellings for First and Second Person Singular Agentive Pronouns.....................217

31. Spellings for First and Second Person Plural Agentive and Dative.......................218

32. Spellings for Singular Oblique Pronouns ………………………….................220

33. Spellings for Third Person Plural Oblique Forms..................................................221

34. Spellings for First and Second Person Possessive Adjectives..............................222

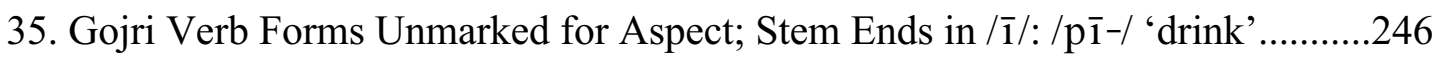

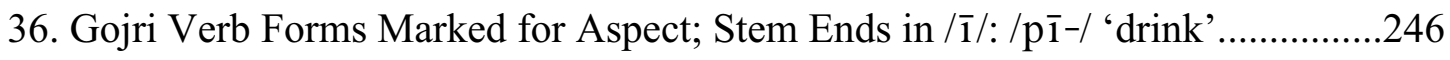

37. Gojri Verb Forms Unmarked for Aspect; Stem Ends in /e/: /le/ 'take'................247

38: Gojri Verb Forms Marked for Aspect; Stem Ends in /e/: /le-/ 'take'..................247

39. Gojri Verb Forms Unmarked for Aspect; Stem Ends in /o/: /kho-/ 'pick'..........248

40. Gojri Verb Forms Marked for Aspect: Stem Ends in /o/: /kho-/ 'pick' ...............248

41. Gojri Verb Forms Unmarked for Aspect; Stem Ends in /ó/: /kó/ 'slaughter'.......249 
42. Gojri Verb Forms Marked for Aspect; Stem Ends in /o/: /kó-/ 'slaughter'

43. Gojri Verb Forms Unmarked for Aspect; Stem Ends in /ع/: /pe-/ 'fall'

44. Gojri Verb Forms Marked for Aspect; Stem Ends in /ع/: /p $\varepsilon^{-/}$'fall' .250

45. Gojri Verb Forms Unmarked for Aspect; Stem Ends in /ع́/: /ré-/ 'stay' .251

46. Gojri Verb Forms Marked for Aspect; Stem Ends in /é/: /ré-/ 'stay' .251

47. Gojri Verb Forms Unmarked for Aspect; Stem Ends in $/ \bar{a} /: / \bar{a}-/$ 'come' .252

48. Gojri Verb Forms Marked for Aspect; Stem Ends in $/ \bar{a} /: / \bar{a}-/$ 'come' 252

49. Gojri Verb Forms Unmarked for Aspect; Stem Ends in /á/: /lá-/ 'take off' ........253

50. Gojri Verb Forms Marked for Aspect; Stem Ends in /ấ/: /lá-/ 'take off' ............253

51. Gojri Verb Forms Unmarked for Aspect: /de-/ 'give' ......................................254

52. Gojri Verb Forms Marked for Aspect: /de-/ 'give' .........................................254

53. Gojri Verb Forms Unmarked for Aspect: /hò-/ 'be'.......................................255

54. Gojri Verb Forms Marked for Aspect: /hò-/ 'be' ...........................................255

55. Gojri Verb Forms Unmarked for Aspect: /kar/ 'do' ........................................256

56. Gojri Verb Forms Marked for Aspect: /kar-/ ‘do' ..........................................256

57. Gojri Verb Forms Unmarked for Aspect: /čal-/ 'go' ........................................257

58. Gojri Verb Forms Marked for Aspect: /čal-/ 'go' ............................................257 


\begin{abstract}
Gojri belongs to the central group of the Indo-Aryan subfamily of Indo-European languages. Gojri (or Gujari) is spoken by the Gujars (or Gujjars), traditionally nomadic pastoralists, who are scattered widely throughout the northern Subcontinent. While remaining an "oral society" in the classic sense, Gujars in recent decades have begun attending school, organizing politically, and writing poetry and prose in their own language. Today, in part because of government sponsorship, the level of Gojri broadcasting and literary activity is higher than that for other minority languages in the region. To date, however, Gojri lacks an agreed-upon set of writing conventions. Writers and editors tend to write phonetically, and with wildly varying degrees of reference to the conventions of Urdu, the primary language of wider communication and the language of education in most communities.

This study presents descriptions of the phonology and morphology of the two major dialects of Gojri spoken in Pakistan, and compares the analysis of these dialects with the analysis of the Gojri spoken in Punch District of Indian-administered Kashmir (Sharma 1979, 1982). Next, in light of this comparative data and the implications for Gojri-toUrdu literacy, it evaluates various orthographic conventions currently used by leading writers and institutions. This study explores Urdu-based spellings which are linguistically sound and otherwise conducive to transitional literacy, and which lend themselves to orthographic standardization across the east-west dialect continuum. It also includes an extended treatment of the challenge of representing Gojri tone.

This study will provide a foundation for orthographic decisions that take crossxvi
\end{abstract}


dialectical considerations and the reality of a broader Urdu print environment fully into account, potentially enabling Gujars to read the pronunciations of their own dialects from a single text type while maximizing the ease of transfer to and from Urdu. The research presented here will also make the dialects of Gojri spoken in Pakistan accessible to linguists and other scholars, and call attention to the significance of the Western dialect within the greater language community. 


\section{CHAPTER I \\ INTRODUCTION}

\subsection{Gujars and the Gojri Language}

Gojri, or Gujari, ${ }^{1}$ is the language of some 1.4 million or more Gujars (or Gujjars, in Indian transliteration) living in the mountainous areas of northern Afghanistan, northern Pakistan, the disputed region of Kashmir, and northern India (Grimes 2000:439). The Gojri speakers, along with many more ethnic Gujars of the plains who no longer speak Gojri, are the descendants of the ancient Gurjaras whose origins are widely debated. ${ }^{2}$ Gojri-speaking Gujars include nomadic pastoralists who herd sheep and goats or dairy buffalo, settled agriculturalists, and semi-settled agriculturalists who practice seasonal transhumance. The overwhelming majority are Sunni Muslims.

\subsubsection{Language Classification}

Masica (1991:48), following Grierson (LSI IX:925), states that Gojri’s closest relation is the Northeastern Rajasthani language, Mewati. The Rajasthani languages have been classified as belonging to the central group of Indo-Aryan, along with Hindi-Urdu and other languages (Masica 1992:453-456). J.C. Sharma also notes the close relationship between Gojri phonology and that of Punjabi (1982:8-9), the latter's inclusion in the central group being the subject of some dispute (see Shackle 1979). The inner classification of the Indo-Aryan languages including Gojri is by no means settled, and it should be noted that Gojri's stated connections with Rajasthani and Punjabi are made on 
the basis of phonological and morphological observations which do not hold in the same way for both of the two main Gojri dialect types.

\subsubsection{Language Environment}

Gojri, being spoken across such a wide swath of the northern part of the South-Asian subcontinent, is in contact with numerous other languages. The focus of this study is the Gojri of the Hazara region of Pakistan's North-West Frontier Province (NWFP), where Gojri is in contact primarily with Pashto and Hindko. Throughout the NWFP, Gujars typically live at higher elevations than other more socially dominant ethnic groups who speak these languages. Hazara Gujars therefore use Pashto or Hindko for most types of day-to-day out-group communication, with men showing higher degrees of bilingual proficiency than women (Hallberg \& O'Leary 1992:145ff). Many Gujars I have met initially insisted that their mother tongue was Pashto or Hindko, acknowledging Gojri as their language only after I switched from Urdu to Gojri in the conversation.

Pashto is an Iranian language and therefore more distantly related to Gojri. It is the dominant language of wider communication in western Mansehra District and Batagram District of Hazara (see Map 2), and in the area west and southwest of the Indus river that includes Swat, Dir, and much of Afghanistan - an area corresponding roughly longitudewise to the extent of the Western Gojri dialect type. The highest concentrations of Western dialect Gojri speakers in Hazara reside in the Allai and Batagram tehsils of Batagram District and in northern Mansehra District including Black Mountain (/kāḷ ḍàko/), but reliable population figures are not available since the recent Pakistani census did not track ethnicity or minority language affiliation (respondents were asked only to indicate whether they speak Urdu, Punjabi, Sindhi, Pashto, Balochi, or 'other' in their 
homes). In the mid 1990's, a large population of cow-herding Dir Gujars, who speak a form of Western Gojri along with Pashto, migrated from Dir to Haripur District.

Hindko is closely related to Punjabi, and is the language of wider communication in most other areas of Mansehra District, Abbottabad District, and Haripur District of Hazara (Hallberg \& O’Leary 1992), blending gradually into Pahari as one moves eastward into Kashmir and beyond - an area roughly corresponding to that in which Eastern Gojri is spoken. I am told that the highest concentration of Eastern dialect-speaking Gujars in Hazara lives north of Shinkiari in eastern Mansehra District within the area bounded on the west by the Siran river and on the East by the Kunhar river which runs through the Kaghan Valley. Gujars living above the valley floors in this area typically have very few non-Gujar neighbors, whereas Gujars living on the eastern side of the Kaghan Valley and in eastern Abbottabad District live in an ethnically and linguistically mixed environment dominated by Hindko. While a type of Eastern Gojri is still spoken in the Gujar villages of (Upper) Kakul, Nagakki, and Sarban near Abbottabad, language use among younger persons may be giving way to Hindko as it has in other isolated Gujar villages further east and south of Abbottabad.

Urdu, the national language of Pakistan and a language of wider communication (or first language) for many Muslims in northern India, is used extensively in education, the news media, and political and religious discourse. In Pakistan, 'functional literacy' means the ability to read and write in Urdu. The children of some educated Hazara residents are learning Urdu as their first language. Gujars learn Urdu in school or in cities outside Hazara where they are employed, and use Urdu when speaking to all other Pakistanis not speaking Gojri or the Gujar's second language (normally Pashto or Hindko), including tourists. Proficiency varies greatly, with educated men at one end of the continuum and 
uneducated women at the other (Hallberg \& O'Leary 1992). Gujars often tell me that their language is closely related to Urdu, if not its very source. English is the official language of Pakistan, and has already left its mark on the Gojri lexicon (via Urdu) like the other languages mentioned to this point. Gujars attach economic value to Urdu and English proficiency, although only the educated elite have any real skill in the latter. Gujars residing in tourist areas may learn to communicate with foreigners using a limited set of English words and phrases.

Gujar men belonging to the nomadic community are often the most multi-lingual, especially the sheep and goat-herding Bakarwal Gujars (from /bakarī/ 'goat') who range farther than other Gujar pastoralists. Muhajar ('refugee') Bakarwal Gujars, who came from what is now Indian-administered Kashmir in 1947 and migrate seasonally through Hazara, may acquire some Shina for summer use in the Northern Areas of Pakistan, and Potwari or Punjabi proper for winter use in the Punjab. The Allaiwal Bakarwal, who identify themselves as emanating from the Allai area of Batagram District, have traditionally summered in Pashto-dominated areas and wintered in Hindko-dominated areas of Haripur District and in Punjabi-speaking areas further south. The Kaghani Bakarwal spend the summers in Kaghan and winters as far south as Haripur in Abbottabad District, both of which are Hindko-speaking.

\subsubsection{Language Development}

The movement to develop Gojri literature began after the Pakistan-India war of

1965.3 Three now well-known Gujar poets, Sabir Afaqi, and brothers Israil Mahjoor and Mohammad Ismail Zabeeh, founded a literary circle in Nawanshahr near Abbottabad in 1966. They began writing Gojri materials using a slightly modified Urdu script. The 
Pakistani government started broadcasting some of these materials when it launched the 'Radio Trarkel' program in 1967, after which the Indian government began broadcasting Gojri programming from Srinagar. Today there are several other daily Gojri programs broadcast by each government in addition to these original two. Almost all of the Gujars I meet report listening to such programs on shortwave. Gojri television news is now broadcast daily from Islamabad (Hallberg and O’Leary noted Gojri television broadcasting from Srinagar (1992:101)).

The Gojri Adabi Board (=literary board), chaired by Sabir Afaqi, was founded in 1970 in Pakistan-administered Kashmir. It has published seven Gojri and Gojri-related titles since 1976, primarily works of poetry, but struggles for lack of sponsorship. The Urdu magazine, Gujar Goonj occasionally publishes Gujar poetry, but its publishers and those of the Gujar Gazette feel that there is no demand for or interest in Gojri writing. These magazines cater primarily to educated ethnic Gujars of the Pakistani Punjab who do not speak Gojri. I am aware of no Gojri literary activities in Hazara or in any other area of Pakistan.

Since its establishment in 1987, the locus of the prolific Gojri literature production in Indian-administered Kashmir has been the Gojri department of the Jammu and Kashmir Academy of Art, Culture and Languages, which is located in Srinagar and Jammu (Hugoniot \& Polster 1997:8). The Academy's 1998 Publications Catalogue (I do not have a more recent one) lists some fifty-five separate titles containing Gojri poetry, prose, and essays on Gujars and Gojri (many of the latter are in Urdu). In addition, such materials are published periodically in their journal, Gojri Sheeraza. The Gojri Research Institute of the Gurjar Desh Charitable Trust (GDCT) in Jammu also publishes Gojri 
titles, along with the monthly magazine Awaz-e-Gurjar featuring articles in English, Hindi, Urdu, and Gojri.

The August, 2000 issue of this magazine reported that a 12-day 'Workshop on Standardization of the Gojri Script' had been held at the Trust's research library beginning on July 10, 2000 (pp. 30-31). The workshop was convened jointly by the Trust and the Indian government's Central Institute of Indian Languages (CIIL), which was represented by J.C. Sharma, the leading authority on Gojri, along with Dr. I.S. Borkar. Unfortunately, the proceedings of this workshop had not been made available by the time of my last enquiry. Such noteworthy efforts reflect the desire of Gujars, and such non-Gujar stake holders, to standardize the Gojri orthography. In the minds of some, however, the intended beneficiaries of standardization are non-Gujars:

Speaking at the inaugural session of the Workshop Dr. Borkar said that standardization of Gojri Script will facilitate those people who are not conversant of Gojri to read, write and understand Gojri at ease. He recalled that the CIIL, Mysore and GDCT Jammu has already worked out hand-in-glove in organizing two Workshops held at the GDCT, Jammu and CIIL, Mysore to prepare an Intensive Course to teach Gojri as second language to non-Gojri speaking people which bound to go a long way in serving the cause of promotion of Gojri language and literature. (ibid, p. 30; quotation reproduced exactly)

Such comments reinforce my impression that Gojri literary activities to-date are largely by the educated, for the educated.

1.2 Socioeconomic Conditions and the Literacy Situation

According to Ahmed, Gujars rank lowest among the four major ethnic groups of Hazara in terms of education level, percentage of dwellings using some cement construction, and land ownership (1986:110-111). There are no reliable estimates of the literacy rate among Gojri-speaking Gujars in Hazara or other parts of Pakistan. In the 
two Gujar communities profiled in-depth by Hallberg and O'Leary (both villages are unusual in that they have a school), less than half of Gujar men and boys, and scarcely any women and girls, were found to have received any formal education (1992:133-142). Although many government schools were opened in larger villages in Gujar areas of Pakistan during the administration of Benazir Bhutto, the quality of education remains low due to lack of facilities and qualified teachers. Most Gujar children are involved with their parents in subsistence agriculture and/or animal husbandry on marginal tracts of mountainous terrain. Therefore their homes are often a great distance from lowerelevation village schools, making regular attendance difficult, particularly for girls who must comply with cultural notions of modesty. Most boys withdraw before they have acquired basic skills in reading and writing Urdu.

Another factor making functional literacy less accessible to Gujars is that Gujar children, like most other Pakistani children, do not speak Urdu at the time of their enrollment in primary school. From what I am told, the foreign language burden entailed by the Urdu and English curriculum, and a Pashto or Hindko medium of instruction, creates adjustment and motivational problems for many new Gujar students. For this reason and others, Hazara Gujars are very responsive to the suggestion that reading and writing skills could be acquired in their mother tongue and later transferred to Urdu. The idea is new to them because so few Gujars outside of Kashmir have ever seen their language in print, despite the laudable literary activities of an educated elite. Many Hazara Gujars with whom I speak, along with non-Gujar stake holders, value the idea of Gojri literacy and literature to the extent that it is tied to Urdu literacy. Educated Gujars in Pakistan-administered Kashmir, on the other hand, seem to value Gojri literacy and 
literature primarily for reasons other than utility, perhaps because Urdu literacy is more accessible in their area (Hallberg \& O’Leary 1992:99).

Given the Gujars' poverty and educational access problems in Pakistan proper, and the fact that they are scattered widely and thinly over such a vast area, the success both of Gojri-to-Urdu transitional literacy programming and Gojri literature in general (and ultimately, language vitality) will probably depend to a great extent upon the use of Urdubased Gojri writing conventions. This perspective accords with what many recognize as true about the necessary impact of dominant regional languages on the orthographies of incipient literary languages. 4 Walker writes (1987:207):

Whatever can be done to make the V[ERNACULAR] L[ANGUAGE] orthography look like the national language orthography will aid VL literacy acceptance. This is especially important in cases where potential VL readers have already learned to read the N[ATIONAL] L[ANGUAGE]. Ideals of producing a purely scientific alphabet must be sacrificed, if need be, for the highest priority of developing an orthography that is accepted by the people and used. Since the NL has higher status and more socioeconomic power, the prestige of the VL will be enhanced the more that it resembles the NL orthographically.

Referring specifically to the implications for literacy, D'Emilio (1986:22) says that orthography design is

... a task which might seem to be the exclusive role of linguistics - like that of developing an alphabet - should leave the margins of that discipline and consider sociolinguistic and pedagogical factors, like the actual possibilities available to the indigenous populations for becoming literate.

Rather than scientific purism, we should be led by good sense and the practical needs of cultures of oral tradition to deal with a written code.

Urdu-based conventions for Gojri would enhance the 'actual possibilities' for becoming literate, because they lend themselves to a more efficient use of the meager resources at hand; the limited time of working children available for education could be 
maximized, as they would not need to learn both Urdu and Gojri spellings for many common cognate pairs; the instructional capacity of those functionally literate in Urdu could also be maximized, as they could use Gojri primers in non-formal settings with minimal prior orientation to written Gojri. Support from non-Gujar stake holders in Pakistan might also be maximized, including that of some in the education establishment who are otherwise prejudiced against Gojri (see Hallberg \& O'Leary 1992:99), as it could be more readily demonstrated that children were learning Urdu while learning Gojri.

These considerations take on added significance in the case of the Allaiwal, Swati and Muhajar Bakarwal nomads, for whom literacy is perhaps least accessible. Their seasonal migration schedules do not allow for school enrollment in either the summer or winter areas. Unlike Kaghani Bakarwals who own land and often leave their children in lower Kaghan to attend school, these groups travel as whole family units and cannot normally leave children behind. Their livelihood is being threatened in the traditional winter grazing areas due to increased development and cultivation by sedentary peoples, and the closure of government forest areas to grazing. They know that their children need literacy to survive economically, but feel their only option for acquiring literacy is to sell their animals and settle in urban areas. This community therefore represents an urgent need for non-formal literacy programming, which, as I mentioned, has a greater chance of success if Urdu-based Gojri conventions are taught from the beginning. As we shall see in chapters 2 and 3, the Western-type phonology of these Bakarwals corresponds closely to Urdu phonology at the points most relevant to the orthography issue.

\subsection{History of Research into Gojri}

The earliest investigation into Gojri was made in the greater Murree area of extreme northern Punjab by Bailey, who initially published nine pages of Gojri description 
(1903:3-11) and later contributed specimens from two Hazara locations to the 'Gujari' section of the Linguistic Survey of India (Grierson 1973 (c1903): IX:925-981). The latter work, being comparative in nature, included skeletal grammars and text data from Gojri varieties spoken in Hazara, Swat, and Kashmir. The only substantial linguistic description available to-date, however, is Sharma's account of the sound system (1979) and grammar (1982) of the Gojri spoken in the Punch district of Indian-administered Kashmir. The former work provides the database for MacEachern's (1997) investigation of laryngeal cooccurrence restrictions in Gojri. Fragments of the Gojri lexicon, phonology, and grammar are occasionally described in Urdu at a popular level by Gujar scholars such as Sabir Afaqi and the editors of the Sheeraza.

Recent scholarship has focused on the broader sociolinguistic situation. Hallberg and O'Leary (1992) published an extensive survey of the Gojri varieties spoken by settled and semi-settled Gujars in Pakistan and Pakistan-administered Kashmir, positing 'Eastern' and 'Western' dialect clusters on the basis of lexical similarity percentages and intelligibility testing. Hugoniot and Polster (1997) completed a similar survey of the 'Eastern Gujari' spoken by the Dodhi (from /dúd/ 'milk') or dairy buffalo-herding Gujars in Indian-administered Kashmir and the Indian states of Himachal Pradesh and Uttar Pradesh.

One question that has remained unanswered in the literature is the precise relationship between Gojri and Bakarwali, the speech of the Bakarwals, which is thought to be a form of Gojri (Sharma 1982:2). Hallberg and O'Leary write:

There are known to be landless Gujars continuing to pursue a nomadic herding lifestyle, particularly the Bakarwals in Azad Kashmir. The general opinion of settled Gujars in Azad Kashmir was that the Bakarwal Gujari was only slightly different 
from their own, the life style being the main difference between the peoples.

However no linguistic evidence has been collected to substantiate these opinions (1992:108).

Their survey included data from only one semi-nomadic community, in Swat, which they identified by the respondents' self-designation, Ajars (/ājaṛ̂̄ / 'shepherd'), rather than Bakarwal. Interestingly, Grierson, who to my knowledge never used the term Bakarwal, had reported that Ajri, the speech of the sheep-herding Ajars, was a distinct sub-dialect but still nearly identical to the Gujari spoken by cow-herding Gujars in Swat (1973 (c1903): IX: 941, 948). Hugoniot and Polster, mindful of Hallberg and O’Leary's statement, elicited lexical data from a single Bakarwal group. They note only that the relative dissimilarity of the Bakarwal data to the Dodhi data may correspond to small differences in lifestyle and ethnicity (1997:15).

\section{$1.4 \quad$ Current Study}

\subsubsection{Purpose}

The present work describes the phonology and morphology of two varieties of the Bakarwal speech of Hazara, and compares these varieties with each other and with the Punch Gojri described by Sharma $(1979,1982)$. It also explores Urdu-based orthographic conventions which are linguistically sound and otherwise conducive to transitional literacy, and which lend themselves to orthographic standardization across the east-west dialect continuum. The value of an analysis of Hazara Gojri to the latter concern lies in the fact that no description of any Gojri variety spoken in Pakistan has been published since Grierson and, as it turns out, the term Bakarwal is primarily an occupational distinction such that the two varieties under study correspond to and attest the 'Eastern' and 'Western' dialect types posited by Hallberg and O'Leary (see Losey, forthcoming). 5 
The two varieties presented here are the speech of the Allaiwal Bakarwal, approximating 'Western' Gojri, and the speech of the Kaghani Bakarwal, approximating 'Eastern' Gojri. The present study therefore contributes phonological and grammatical data and analysis to Gojri dialectology, a domain which until now has been based exclusively on word lists and intelligibility testing (aside from a few paradigms and comparative notes in Grierson). It also identifies phonological and grammatical phenomena in the Western dialect type which might have bearing on standardization efforts that until now have concerned themselves only with Eastern speech.

This study evaluates various orthographic conventions currently used by leading writers and institutions, in light of the comparative data and the implications for Gojri-toUrdu literacy. My hope is that this study will provide a foundation for future orthographic decisions that take cross-dialectal considerations and the reality of a broader Urdu print environment fully into account, potentially enabling Gujars to read the pronunciations of their own dialects from a single text type while maximizing the ease of transfer to and from Urdu.

\subsubsection{Data Collection and Analysis}

The data were collected during the course of my ongoing field work in Hazara which began in May, 1999, following one year of intensive Urdu study in Murree and later Abbottabad, where I also conducted my research in the winters of 1999-2000 and 20002001. My initial work in Gojri was in the village of Budgran /budgrā / above Kawai in the Kaghan Valley. My family and I have been hosted periodically there and in the summer pastures near Besal by the family of my research assistant, Mohammad Aslam Armani Thikri (/ṭh $\overline{1} \mathrm{kr} \overline{1} /)$, whose speech is virtually identical to the Kaghan Gojri 
attested by data from Mittikot in Hallberg and O'Leary's survey (1992:106). This family was Kaghani Bakarwal, until they sold their goats in the early 90's after my assistant became partially paralyzed in a construction accident and an older brother was killed in a logging accident. My material on Eastern grammar is based on recorded texts given by Mohammad Aslam's mother, oldest brother, and several men living in the area above Kawai.

I began studying the speech of the Allaiwal Bakarwal at Lake Saif-ul-Muluk near Naran in the Kaghan Valley in July of 1999, with help from a family we had met earlier in their winter grazing area near Mang, located between Haripur and Khanpur. That Fall I hired a son of our Allaiwal hosts, Mumtaz Ahmad Bania /bāṇīāa/, as a second research assistant. My material on Western grammar is based primarily on recorded texts of this man's speech, which patterns closely with the Western samples reported in Hallberg and O'Leary (1992), particularly with the two from Swat. 6 In a footnote, Hallberg and O’Leary (1992:131) mention Barth's observation (1956:77) that Swat Gujars claimed their ancestors had immigrated to the area from Allai. As some of Hallberg and O'Leary's (1992:106) Gilgit and Chitral area respondents claim immigration (presumably subsequent) from Swat, it is most unfortunate their survey did not include a sample from Allai.

My material on phonology is based on separate Kaghan and Allaiwal word lists which I began compiling in 1999. In Appendix B I have presented some of these words using the standard 210-item list used by Hallberg and O'Leary (1992), so as to facilitate comparison. In addition I have included word lists taken from members of the Allaiwal Bakarwal Muhajar and Kunhari Bakarwal Muhajar communities. I collected the two 
Muhajar lists in March, 2002, during a one-month trip to Pakistan (my family and I had been evacuated in September, 2001), but due to the security situation I was not able to elicit a word list from any Gujars settled in the Allai area. While I did manage to check my material on phonology and tone at that time, I was forced to check my grammatical material primarily by telephone during the evacuation period.

I have attempted to present my analysis, for the most part, according to the organization and linguistic category labels used in Masica's excellent handbook on the Indo-Aryan languages (1991). At other points I follow Payne's guide to morphosyntactic description (1997).

\subsubsection{Overview of Remaining Chapters}

Chapter 2 presents the phonemes and common phonological processes of Gojri, with attention to salient variation between Eastern and Western varieties, and then explores the representation of these phonemes in the Gojri script. Chapter 3 describes Gojri tonal phenomena and evaluates various solutions to their orthographic representation. Chapter 4 is a comparative study of Gojri morphosyntax that includes extensive illustrative data from both dialects, which is supplemented by additional verb paradigms in Appendix C. Chapter 5 considers the standardization of Gojri and evaluates Gojri spelling conventions in light of the linguistic analysis presented in preceding chapters and current research in related disciplines. Appendix A lists abbreviations and outlines the method of data presentation used throughout this work. 


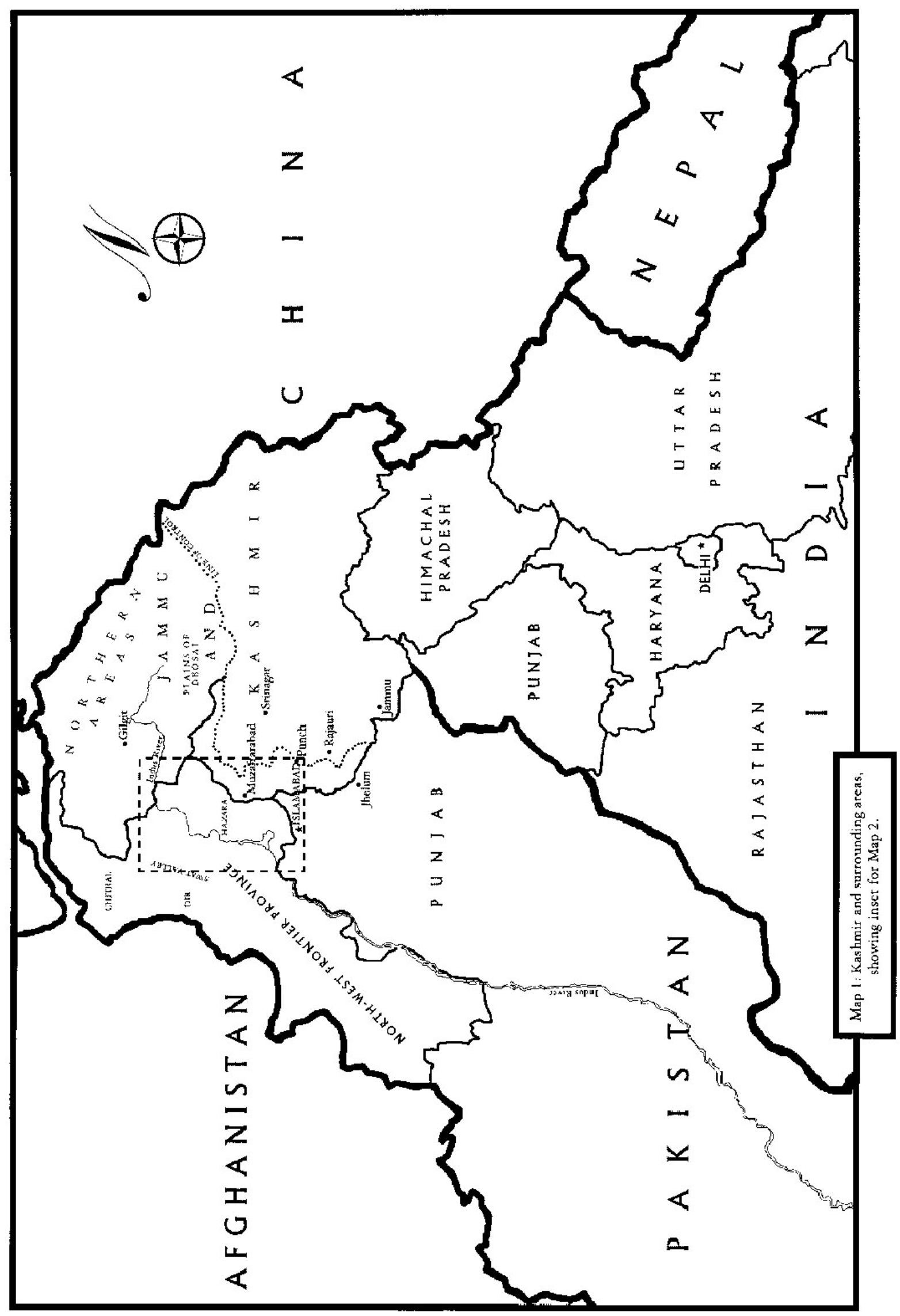




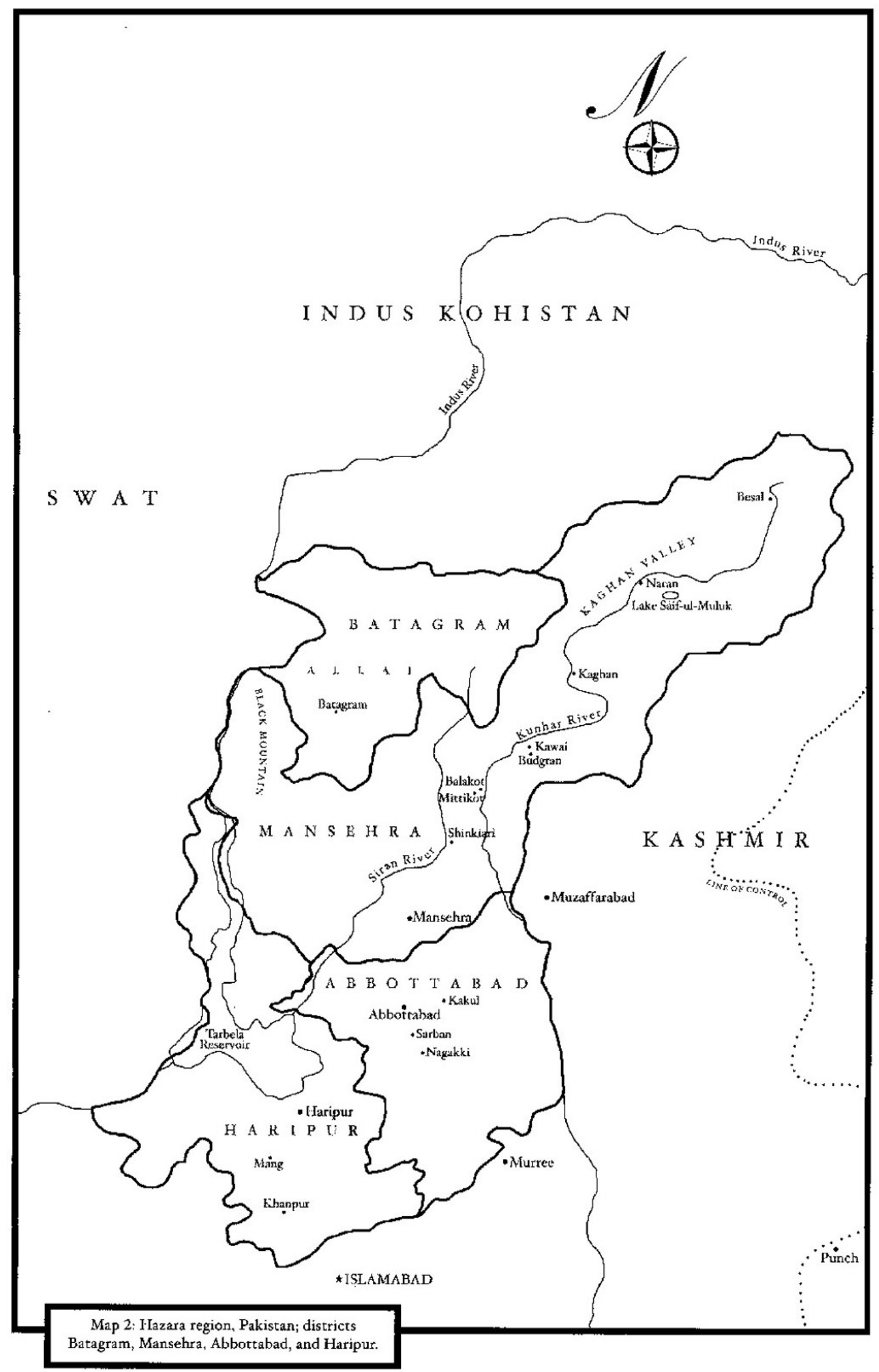




\section{CHAPTER II}

\section{COMPARATIVE GOJRI PHONOLOGY AND THE GOJRI SCRIPT}

What follows is a preliminary analysis of the basic phonemics of Gojri, with reference to salient variations between the Allaiwal and Kaghani dialects, representing the broader Western and Eastern speech types, respectively. I reference Sharma's more extensive analysis of Punch Gojri (1982) wherever comparison is warranted. For comparison of lexical data within Pakistan I have shown unique Western lexical forms in parentheses where not otherwise introduced. Wherever a Western form is shown in parentheses, the cognate shown immediately to the left or immediately above is uniquely Eastern.

Unmarked forms are pronounced the same for both dialects.

\subsection{Gojri Consonant Phonemes}

The consonant phonemes of Gojri are shown in Table 1.

Table 1. Gojri Consonant Phonemes

Labial Dental Retroflex $\quad$ Palatal $\quad$ Velar Glottal

Stop

$\begin{array}{lllll}\text { aspirated } & \mathrm{ph} & \mathrm{th} & \text { th } & \mathrm{kh} \\ \text { voiceless } & \mathrm{p} & \mathrm{t} & \mathrm{t} & \mathrm{k} \\ \text { voiced } & \mathrm{b} & \mathrm{d} & \mathrm{d} & \mathrm{g}\end{array}$

Affricate

aspirated

čh

voiceless

č

voiced

$\check{\mathrm{j}}$ 
Table 1 cont.

Fricative

voiceless

voiced

$\mathrm{S}$

Z

$\check{S}$

$\mathrm{X}$

$\mathrm{h}$

Nasal

$\mathrm{m}$

n

!

Glide

W

$\mathrm{y}$

Flap

r

r

Lateral (approximant)

1

\subsubsection{Nasals}

In Gojri there are three phonemic nasals, the bilabial $/ \mathrm{m} /$, the dental $/ \mathrm{n} /$, and the retroflex /ṇ/.

\subsubsection{Contrast}

(1) Phonemic nasal contrasts (unique Western forms shown in parentheses)

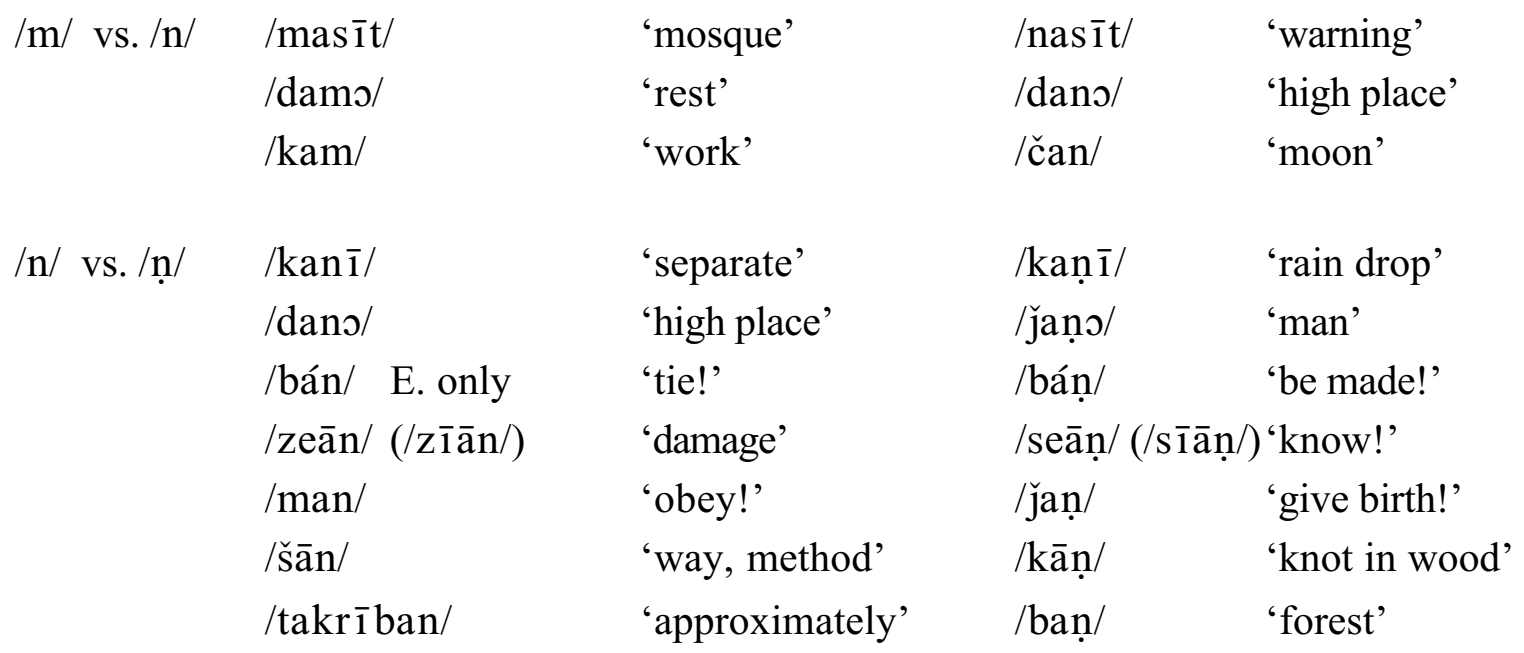




\subsubsection{Distribution}

Only $/ \mathrm{m} /$ and $/ \mathrm{n} /$ may occur in word-initial position. The retroflex nasal /n $/$, like the retroflex liquids $/ \underline{r} /$ and $/ \underline{l} /$, does not occur initially. All three nasal phonemes occur medially and finally.

(2) Distribution of nasal phonemes in words

\begin{tabular}{|c|c|c|c|c|}
\hline initial & & intervoce & & final \\
\hline /mačh $\overline{1} /$ & 'fish' & /māms/ & 'maternal uncle' & /thūm/'garlic' \\
\hline /nak/ & 'nose' & /nāno/ & 'paternal grandfather' & /jān/ 'life' \\
\hline -------. & -------- & /dāṇı/ & 'seed, grain' & /lūṇ/ 'salt' \\
\hline
\end{tabular}

\subsubsection{Variation}

The nasal phoneme /n/ assimilates in clusters of type /n/ + voiced plosive to the plosive's point of articulation. Representative examples of this process are shown in (3).
$/ \mathrm{n} /$ is $[\mathrm{n}]$ before a voiced dental plosive [kınd] /kand/ 'wall'

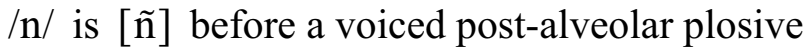
$[\check{\mathbf{j}} \Lambda \tilde{\mathrm{n}} \tilde{\mathrm{j}}] \quad / \mathrm{jan} \breve{\mathrm{j}} / \quad$ 'wedding
$/ \mathrm{n} /$ is [n] before a voiced retroflex plosive
[kıṇ̣ ] /kanḍ// 'back'
$/ \mathrm{n} /$ is $[\mathrm{y}]$ before a voiced velar plosive
[khıyg] /khang/ 'cough'

This process does not extend to the labial area, as the cluster [mb] is disallowed in Gojri.

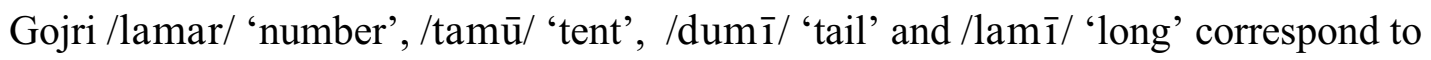
$\mathrm{Urdu} / \mathrm{nambar} /, / \operatorname{tamb} \overline{\mathrm{u}} /$, /dumb $\overline{1} /$ and $/ \operatorname{lamb} \overline{\mathbf{1}} /$ respectively. The cluster $[\mathrm{mp}]$ is heard only in English loans such as 'pump' and 'jump.' Voiceless examples for other points of articulation are too few at present to establish their identity over and against a more probable analysis of nasalized vowel + consonant. I have taken $/ \mathrm{n} /$ as basic because it occurs finally and in a wide range of clusters with other consonants, while [n] does not 
otherwise occur in clusters and $[\tilde{\mathrm{n}}]$ and $[\mathrm{y}]$ never occur independently of $/ \check{\mathrm{j}} / \mathrm{and} / \mathrm{g} /$, respectively.

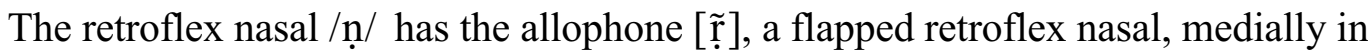
normal speech, e.g. [paṛ̂i] /pāṇ̄ī/ 'water.'

\subsubsection{Laterals and Flaps}

Both dialects of Gojri spoken in Pakistan feature the alveolar and retroflex laterals, /1/ and $/ 1 /$, respectively; and the alveolar and retroflex flaps, $/ \mathrm{r} /$ and $/ \mathrm{r} /$, respectively.

A geminate retroflex /ḷ// occurs in the Eastern subdialect spoken near Muzaffarabad, but not in the Kaghani or Allaiwal varieties I have studied. It corresponds to the cluster /rṛ/ in Kaghani and Allaiwal Gojri, as shown in (4):

(4) Correspondence of Muzaffarabad /ḷ!/ with Kaghani and Allaiwal /rṛ/

\begin{tabular}{|c|c|c|}
\hline Muzaffarabad & Kaghani and $\mathrm{Al}$ & \\
\hline /naḹī/ & /narṝ̣/ & 'throat' \\
\hline /khaḷ! $\overline{1} /$ & /kharṝī/ & 'goat skin milk bag' \\
\hline /čùḷ!̣̂̄/ & /čùrṛ̣̂1//jùrụ̂̄i / & 'skin wrinkles' \\
\hline /khollı/ / & /khorṛı/ & 'mature' (of trees, people) \\
\hline /čhiḷ̣̂̄/ & /čhirṛ̂̄/ & 'skin of fruit, vegetables, and nuts' \\
\hline /goḷlo/ & /gorṛ̣/ & 'name of a caste' \\
\hline /šill!̣i & /Širṝ̣/ & 'mushroom' \\
\hline /pal!̣i / & /parṛī/ & 'kind of demonic creature' \\
\hline
\end{tabular}

\subsubsection{Contrast}

(5) Phonemic lateral and flap contrasts

\begin{tabular}{|c|c|c|c|}
\hline Vs. / $/ \mathbf{l} /$ & $\begin{array}{l}\text { /čorī// } \\
\text { /b̄īr/ }\end{array}$ & $\begin{array}{l}\text { 'robbery' } \\
\text { 'friend' }\end{array}$ & $\begin{array}{l}\text { /čorị̄/ } \\
\text { /b̄ìr/ }\end{array}$ \\
\hline
\end{tabular}




\begin{tabular}{|c|c|c|c|c|}
\hline$/ \mathrm{r} / \mathrm{vs} . / 1 /$ & $\begin{array}{l}\text { /rat/ } \\
\text { /borī/ } \\
\text { /sir/ }\end{array}$ & $\begin{array}{l}\text { 'blood' } \\
\text { 'gunnysack' } \\
\text { 'head' }\end{array}$ & $\begin{array}{l}\text { /lat/ } \\
\text { /bolī/ } \\
\text { /sil/ }\end{array}$ & $\begin{array}{l}\text { 'lower leg' } \\
\text { 'speech' } \\
\text { 'rock slab' }\end{array}$ \\
\hline /1/ vs. /1̣/ & $\begin{array}{l}\text { /pīlı/ } \\
\text { /gelī/ } \\
\text { /palı/ } \\
\text { /nāl/ } \\
\text { /hà̀l/ } \\
\text { /kol/ }\end{array}$ & $\begin{array}{l}\text { 'yellow color' } \\
\text { 'log' } \\
\text { 'shawl' } \\
\text { 'horseshoe' } \\
\text { 'condition' } \\
\text { 'promise' }\end{array}$ & 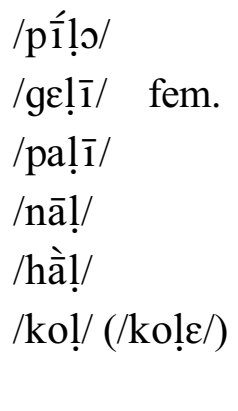 & $\begin{array}{l}\text { 'ant' } \\
\text { 'wide' } \\
\text { 'dry animal' } \\
\text { 'with' } \\
\text { 'plow' } \\
\text { possessive } \\
\text { postposition }\end{array}$ \\
\hline /ṛ/ vs. /l! & $\begin{array}{l}\text { /sāṛı/ } \\
\text { /bāṛ̣/ }\end{array}$ & $\begin{array}{l}\text { 'absence' } \\
\text { 'bring inside!' }\end{array}$ & $\begin{array}{l}\text { /sāḷ’/ } \\
\text { /bāḷ / }\end{array}$ & $\begin{array}{l}\text { 'wife's brother' } \\
\text { 'ignite!' }\end{array}$ \\
\hline
\end{tabular}

The phonemic status of / $\mathbf{r} /$ warrants discussion given that in many related languages it is an allophone of /ḍ/, and the fact that Masica says it is not reported for 'Gujari' (1991:97). The latter is surely a mistake since Sharma (1982) is his only cited source for Gojri and Sharma reports both / $\mathbf{r} /$ and / $\mathbf{d} /$ as phonemic $(1982: 11,19)$. While contrasts like those in 2.1.4.1 below prove that $/ \mathrm{r} /$ is in fact a Gojri phoneme, other comparative data highlight its close relationship with / $\mathbf{d} /$ cross-linguistically:
/thoḍ̄/ 'chin'
vs. Urdu /ṭhor $\overline{1} /$ 'chin'
/búḍo/ 'old man’
vs. Urdu /buṛhā/ 'old man'
/ḍćḍ/ 'one and a half'
vs. Urdu /ḍeṛh/ 'one and a half'
/čhoḍ/ 'leave alone!' W.only
vs. Eastern and Urdu /čhoṛ! 'leave alone!'

\subsubsection{Distribution}

The retroflex liquids /ṛ/ and / $\mathbf{l} /$, like retroflex /ṇ/, do not occur in initial position. All Gojri liquids occur medially and finally. 
(7) Distribution of laterals and flaps in words

\begin{tabular}{|c|c|c|c|c|c|}
\hline initial & & intervocalic & & final & \\
\hline /rang/ & 'color' & /mors/ & 'hole' & /čor/ & 'thief' \\
\hline & 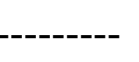 & /baṝil fem. & 'large' & /bāṛ/ & 'fence' \\
\hline /lelo/ & 'ram' & $\begin{array}{ll}\text { /polo/ fem. } \\
\text { /pālo/ }\end{array}$ & $\begin{array}{l}\text { 'soft' } \\
\text { 'coldness' }\end{array}$ & $\begin{array}{l}/ \mathrm{mul} / \\
/ \mathrm{pul} /\end{array}$ & $\begin{array}{l}\text { 'price' } \\
\text { 'bridge' }\end{array}$ \\
\hline
\end{tabular}

\subsubsection{Variation}

An intervocalic trill, [ $\tilde{\mathrm{r}}]$, in the phonetic data may represent an underlying geminate $/ \mathrm{rr} /$. However, since all of the examples in (8) feature [ $\tilde{\mathrm{r}}]$ between the short vowel $/ \mathrm{u} /$ and a gender-number agreement suffix $(/-\mathrm{O} /$ or $/-\overline{1} /)$, it is premature to analyze the gemination as having phonemic status.

(8) Possible contrasts of medial / $/ \mathrm{r} /$ and $/ \mathrm{rr} /$

[khữ̃] /khuro/ 'foot print' vs. /koro/ 'frost, ice' and /khoro/ masc. 'rough' [čhur̃o] /čhuro/ 'big knife' vs. /pūro/ masc. 'entire' and /sur/ 'happiness' [tur̄i ] /turī/ 'clove (of garlic)' vs. /pūrī/ fem. 'entire' and /sur/ 'happiness'

\subsubsection{Labial Area Consonants}

Gojri features a three-way labial stop opposition: /ph/, /p/, /b/; the labial glide /w/, and the labio-dental fricative /f/. Most of the nouns containing/f/ are of foreign origin (see Masica 1991:92).

\subsubsection{Contrast}

(9) Phonemic labial area contrasts

$\begin{array}{lllll}/ \mathrm{ph} / \mathrm{vs} . / \mathrm{p} / & / \mathrm{phul} / & \text { 'flower' } & / \mathrm{pul} / & \text { 'bridge' } \\ & / \text { guph } / / & \text { 'hip' } & / \text { ṭop } / / & \text { 'hat' }\end{array}$




\begin{tabular}{|c|c|c|c|c|}
\hline$/ \mathrm{p} / \mathrm{vs} . / \mathrm{b} /$ & $\begin{array}{l}\text { /pūt/ } \\
\text { /kāp̄is/ } \\
\text { /bāp/ }\end{array}$ & $\begin{array}{l}\text { 'son' } \\
\text { 'copy book' } \\
\text { 'father' }\end{array}$ & $\begin{array}{l}\text { /būt / } \\
\text { /kābū/ } \\
\text { /xāb/ }\end{array}$ & $\begin{array}{l}\text { 'shoe' } \\
\text { 'control' } \\
\text { 'dream' }\end{array}$ \\
\hline$/ \mathrm{b} /$ vs. $/ \mathrm{m} /$ & $\begin{array}{l}\text { /bačhī/ fem. } \\
\text { /dabo/ } \\
\text { /nasīb/ }\end{array}$ & $\begin{array}{l}\text { 'calf' } \\
\text { 'box' } \\
\text { 'luck, fate' }\end{array}$ & $\begin{array}{l}\text { /mačh̄̄i } \\
\text { /damı/ } \\
\text { /taksīm/ }\end{array}$ & $\begin{array}{l}\text { 'fish' } \\
\text { 'rest' } \\
\text { 'division' }\end{array}$ \\
\hline$/ \mathrm{b} / \mathrm{vs} . / \mathrm{w} /[\mathrm{v}]$ & $\begin{array}{l}\text { /bas/ } \\
\text { /čhab̄̄/ } \\
\text { /bābo/ }\end{array}$ & $\begin{array}{l}\text { 'enough!' / 'reside!' } \\
\text { 'twenty-six' } \\
\text { 'old man' }\end{array}$ & $\begin{array}{l}\text { /was/[v } \Lambda \mathrm{s}] \\
/ \check{c} \mathrm{aw} \overline{\mathbf{1}} /[\check{\mathrm{c}} \Lambda \mathrm{vi}] \\
/ \text { nāws/[na:vo] }\end{array}$ & $\begin{array}{l}\text { 'resources' } \\
\text { 'twenty-four' } \\
\text { 'water spout' }\end{array}$ \\
\hline$/ \mathrm{f} / \mathrm{vs} . / \mathrm{w} /[\mathrm{v}]$ & $\begin{array}{l}\text { /fāydo/ } \\
\text { /safo/ }\end{array}$ & $\begin{array}{l}\text { 'benefit' } \\
\text { 'page' }\end{array}$ & $\begin{array}{l}\text { /wāydo/ [va:ydo] } \\
\text { /sāwo/ [sa:vo] }\end{array}$ & $\begin{array}{l}\text { 'promise' } \\
\text { 'blue-grey } \\
\text { color' }\end{array}$ \\
\hline /f/ vs. /ph/ & /māfī/ & 'forgiveness & $\begin{array}{l}\text { /phagạ̣/ } \\
\text { /guphī/ }\end{array}$ & $\begin{array}{l}\text { '3rd lunar } \\
\text { month' } \\
\text { 'hip' }\end{array}$ \\
\hline
\end{tabular}

\subsubsection{Distribution}

The labial phonemes occur in all positions with the exception that $/ \mathrm{ph} /$ does not occur word-finally in my data. MacEachern's (1997) laryngeal cooccurrence restriction for Gojri predicts that /ph/ will never cooccur in a word with any aspirated stop but itself (see 2.1.5.1).

The word given for /w/ in final position could alternately be analyzed as /báū/. The case for medial /w/ is also tentative in that it is attested here and above only by a weakened numeric compound and by words in which it appears to be epenthetic (see discussion below). 
(10) Distribution of labial phonemes in words

initial

/ph/ /phal/ 'fruit'

/p/ /pūt/ 'son'

/b/ /būṭo/ 'tree'

/w/ /wém/ 'worry'

/f/ /foṭū/ 'picture'

$$
\text { intervocalic }
$$

/tràphur/ (/dràphur/) 'skin bumps'

/topī/ 'cap, hat'

/bābo/ 'old man'

/dấwo/(/dāwo/) 'claim’

/dafo/ 'ordinance, restriction' final

/tāp/ 'fever'
/ǰāàb/ 'answer'
/báw/ 'daughter-in-
law'
/sāf/ 'clean'

\subsubsection{Variation}

$/ \mathrm{w} /$ is realized phonetically in some contexts as a labial-velar approximant $[\mathrm{w}]$, in other contexts as a labiodental fricative [v], and in yet other contexts as a bilabial fricative [ $\beta]$. The latter is observed in the speech of many Gujars before the back rounded vowels /o/ and /o/, most notably in the third masculine singular distal nominative pronoun /wó/ [ßó] 'he' (all other distal nominatives begin with [v]), and epenthetically between verb stems ending in a vowel and the eastern second plural personal concord suffix /o/, e.g. [hòßo kā] 'you will be.' In the speech of some eastern Gujars, including that of Dr. Sabir Afaqi, /w/ is altogether absent in these same contexts: /ó/ 'he'; /hòo kâa/ 'you will be.' I have also recorded forms such as /hòwe ko/ 'it will be' from the eastern variety spoken between the Siran and Kunhar rivers in Mansehra District. The lightly fricated [v] occurs initially and medially before all other vowels, while [w] occurs as labialization of an initial consonant or in Eastern as a glide component of the nucleus as shown in (11): (11) $[\mathrm{w}]$ as a semi-vowel in some Eastern Gojri nouns
[sa:wṇ]
'8th lunar month'
vs. [sa:ßuṇ] / [swa:ṇ]
(Western variant) 


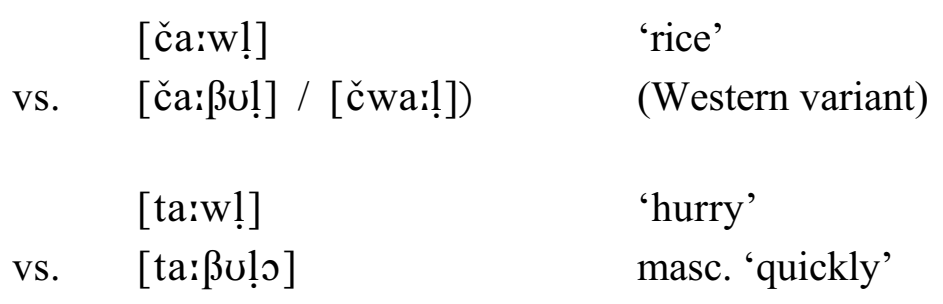

Words beginning with a $\left[\mathrm{C}^{\mathrm{w}}+\mathrm{V}\right]$ sequence are presented in (12).

(12) Labialized initial consonants in Gojri

$\begin{array}{lll}\text { /kwāro/ } & \text { 'unmarried man' } & \\ \text { /šwāḷı/ } & \text { 'groom' } & \\ \text { /dwā šwā/ } & \text { 'prayer and such' } & \\ \text { /ǰāa/ } & \text { 'answer' } & \text { cf. Urdu /javāāb/ } \\ \text { /gwá/ } & \text { 'witness' } & \text { cf. Urdu /gavāh/ } \\ \text { /dwāy/ } & \text { 'medicine' } & \text { cf. Urdu /davāy/ } \\ \text { /swāḷ/ } & \text { 'put to sleep' } & \end{array}$

Sharma does not report a phonetic [v] for Punch-Rajauri Gojri, nor is it possible to tell which instances of initial and medial $[w]$ in his data might actually be [ $\beta]$ (1979:109). This is also the case with the Gujari word lists reported in Hallberg's survey (1992:259283), where perhaps a decision was made to simply represent the phoneme as /w/ in an otherwise phonetic transcription.

While /b/ and /w/ both have phonemic status in both dialects, there are many examples of cross-dialectal variation in initial position such as those in (13):

\begin{tabular}{|c|c|c|}
\hline Eastern & Western & \\
\hline /wārī/ [va:ri] & /bārīi/ & 'turn, time' \\
\hline /wot!/ [ßß:t] & /boṭ/ & 'vote' \\
\hline /wile/ [viḷ] & /bile/ loc. & 'time, occasion' \\
\hline /wī// [vi: ] & $/ \mathrm{b} \grave{1} /$ & $\begin{array}{l}\text { 'also' (the Western variant } / \mathrm{m} \overline{\mathbf{1}} / \text { is also very } \\
\text { common) }\end{array}$ \\
\hline
\end{tabular}


In addition, while /ph/ and /f/ are both phonemic in both dialects, there are many examples of cross-dialectal variation such as those in (14):

(14) Eastern Western

$\begin{array}{lll}\text { /fir/ } & \text { /phir/ } & \text { 'wander!' } \\ \text { /fulāṇı/ } & \text { /phulāṇı/masc. 'such and such' } \\ \text { /xafā/ } & \text { /xapā/ } & \text { 'upset' }\end{array}$

Various forms in the examples above represent attempts by the Western dialect both to preserve the indigenous segments $/ \mathrm{b} /$ and $/ \mathrm{ph} /$ while resisting the foreign $/ \mathrm{f} /$, whereas Eastern items reveal both the incorporation of $/ \mathrm{f} /$ and the weakening of $/ \mathrm{ph} / \mathrm{and} / \mathrm{b} /$. The difference between the Western and Eastern responses to /f/ and to a lesser extent, /z/, may have something to do with relative degrees of historic Islamicization (Masica 1991:92).

\subsubsection{General Dental Area Consonants}

Gojri features a three-way opposition between voiceless aspirated, voiceless, and voiced stops in the labial, general dental, and velar areas. Phonemic contrasts in the general dental area further subdivide into those comprised by the dental stops $/ \mathrm{th} /, \mathrm{t} / \mathrm{and}$

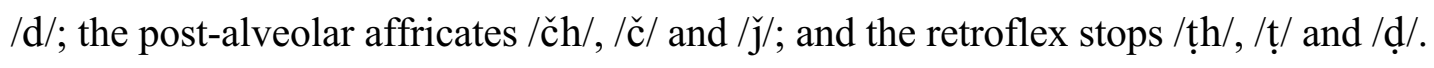
The dental area fricatives are dental $/ \mathrm{s} /$ and $/ \mathbf{z} /$ and the post-alveolar $/ \check{\mathbf{S}} /$. The dental area nasals and liquids contrast alveolar and retroflex articulation: /n/ and /ṇ/, /1/ and /1̣/, and /r/ and $/ \mathbf{r} /$.

Word-initially and word-finally, the palatal glide /y/ - phonetic [j] in the IPA transcription - is roughly equivalent in quality to the close (high) vowel $/ \overline{1} /$ (final $/ y /$ in words like /pày/ (/bà̀y/) 'brother' might also, therefore, be analyzed as diphthongal, e.g. 
/pà̀ $/(/$ bà $\overline{1} /))$. Medial /y/, however, is equivalent in quality to the vowel /e/ (but shorter in length) and contrasts with geminated /yy/, the latter achieving a higher articulatory target (i.e. that of the IPA [j]) due to its greater length. This transcriptional decision is driven by the need to represent the two glides in question in a manner compatible with Romanized transcriptions of Hindi-Urdu (it is not an issue in the script, see 2.6.1.3), which to my knowledge have not had to accommodate this contrast (even though it may occur phonetically, e.g. [a: 'a:/ '[he] came' vs. /a:y:e:/ 'please come'). For example, medial /y/ always indicates the lower, shorter glide in the standard transcription of HindiUrdu words like /pāyah/ [pa: '⿳a:] 'furniture leg' (cf. Gojri /pāyā/ [pa:'a:] 'furniture legs') and /āyā/ [a: $\left.{ }^{\mathrm{y}} \mathrm{a}:\right]$ 'he came' (cf. Gojri /āeā/ [a: ${ }^{\mathrm{y}} \mathrm{a}:{ }^{\prime}$ '[they] came'). Gojri, however, features the higher glide in some lexical stems, e.g. /pāyys/ [pa:y:o] 'grazing fee', necessitating the use of geminated /yy/ to ensure correct interpretation as IPA [j].

\subsubsection{Contrast}

(15) Dental area stop, affricate, and fricative phonemic contrasts

\begin{tabular}{|c|c|c|c|c|}
\hline \multirow[t]{3}{*}{$/ \mathrm{d} / \mathrm{vs} . / \mathrm{n} /$} & /das/ & 'tell!' & /nas/ & 'run away!' \\
\hline & $/ \operatorname{kad} \bar{u} /$ & ‘squash' & /̆janū/ & 'knee’' \\
\hline & /sad/ & 'call!' & $/ \mathrm{man} /$ & 'obey!' \\
\hline \multirow[t]{3}{*}{$/ \mathrm{d} / \mathrm{vs} . / \mathrm{r} /$} & $/ \mathrm{d} \overline{1} \sim /$ & 'sun' & $/ \mathrm{r} \overline{1} \sim /$ & 'oak tree' \\
\hline & /sādī/ fem. & 'simple' & /sārīl fem. & 'entire' \\
\hline & /yād/ & 'memory' & /yār/ & 'friend' \\
\hline \multirow[t]{3}{*}{ /d/ vs. /l/ } & /de/ & 'give!' & /le/ & 'take!' \\
\hline & /udīk/ & 'waiting' & /ulī/ & 'mold' \\
\hline & /sād/ & 'taste' & /sāl/ & ‘year' \\
\hline
\end{tabular}




\begin{tabular}{|c|c|c|c|c|}
\hline /ṇ/ vs. /ḍ/ & $\begin{array}{l}\text { /kạ̣̄̄/ } \\
\text { /khāṇ/ }\end{array}$ & $\begin{array}{l}\text { 'drop' } \\
\text { 'a mine' }\end{array}$ & $\begin{array}{l}\text { /gaḍ̄ī/ } \\
\text { /lāḍ// }\end{array}$ & $\begin{array}{l}\text { 'bundle' also 'vehicle' } \\
\text { 'affection' }\end{array}$ \\
\hline /ṇ/ vs. /ṛp/ & $\begin{array}{l}\text { /kạ̣̄̄/ } \\
\text { /kūṇ/ }\end{array}$ & $\begin{array}{l}\text { 'rain drop' } \\
\text { 'a tilt or lean' }\end{array}$ & $\begin{array}{l}\text { /kaṝ̄ } / \\
/ \mathrm{kūr} /\end{array}$ & $\begin{array}{l}\text { 'ceiling beam' } \\
\text { 'a lie' }\end{array}$ \\
\hline$/ \mathrm{th} / \mathrm{vs} . / \mathrm{t} /$ & $\begin{array}{l}\text { /tham/ } \\
\text { /gutho/ } \\
\text { /gith/ }\end{array}$ & $\begin{array}{l}\text { 'post,pillar' } \\
\text { 'big bag' } \\
\text { 'handspan' }\end{array}$ & $\begin{array}{l}\text { /tam/ pl. } \\
\text { /guto/ } \\
\text { /it/ }\end{array}$ & $\begin{array}{l}\text { 'you' } \\
\text { 'braid' } \\
\text { 'here' }\end{array}$ \\
\hline$/ \mathrm{t} /$ vs. $/ \mathrm{d} /$ & $\begin{array}{l}\text { /tam/ pl. } \\
/ \text { dāt } \overline{1} / \\
\text { /rāt/ }\end{array}$ & $\begin{array}{l}\text { 'you' } \\
\text { 'sickle' }\end{array}$ & $\begin{array}{l}\text { /dam/ } \\
\text { /dād̄̄i / } \\
\text { /sād/ }\end{array}$ & $\begin{array}{l}\text { 'moment' } \\
\text { 'paternal } \\
\text { grandmother' } \\
\text { 'taste' }\end{array}$ \\
\hline /ț/ vs. /ḍ/ & $\begin{array}{l}\text { /țak/ } \\
\text { /hàṭ̄i/ } \\
\text { /ḍaṭ/ }\end{array}$ & $\begin{array}{l}\text { 'stain' } \\
\text { 'shop, store' } \\
\text { 'filled' }\end{array}$ & $\begin{array}{l}\text { /ḍak/ trans. } \\
\text { /hàḍ̄i/ } \\
\text { /ḍaḍ// }\end{array}$ & $\begin{array}{l}\text { 'stop!' } \\
\text { 'bone' } \\
\text { 'toad' }\end{array}$ \\
\hline /d/ vs. /ḍ/ & $\begin{array}{l}\text { /dand/ } \\
/ \operatorname{nad} \overline{1} / \\
\text { /kand/ }\end{array}$ & $\begin{array}{l}\text { 'tooth' } \\
\text { 'river' } \\
\text { 'wall' }\end{array}$ & $\begin{array}{l}\text { /ḍanḍ// } \\
\text { /gaḍ̄/ } \\
\text { /kanḍ/ }\end{array}$ & $\begin{array}{l}\text { 'voice' } \\
\text { 'bundle' also 'vehicle' } \\
\text { 'back' }\end{array}$ \\
\hline /ḍ/ vs. /ṛ/ & $\begin{array}{l}\text { /roḍ̂/ } \\
\text { /koḍ̂̄// } \\
\text { /ṭhoḍ̄î/ } \\
\text { /gạ̣ī/ } \\
\text { /lāḍ/ }\end{array}$ & $\begin{array}{l}\text { 'bald man' } \\
\text { 'shell' } \\
\text { 'chin' } \\
\text { 'car; bundle' } \\
\text { 'affection' }\end{array}$ & 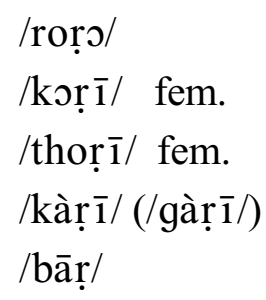 & $\begin{array}{l}\text { 'drought' } \\
\text { 'sour' } \\
\text { 'a little' } \\
\text { 'wrist watch' } \\
\text { 'fence' }\end{array}$ \\
\hline /ḍ/ vs. /ḷ/ & $\begin{array}{l}\text { /gaḍ̄î/ } \\
\text { /lāḍ// }\end{array}$ & $\begin{array}{l}\text { 'car; bundle' } \\
\text { 'affection' }\end{array}$ & $\begin{array}{l}\text { /gạ̣ī/ } \\
\text { /hạ̀̀!/ }\end{array}$ & $\begin{array}{l}\text { 'street' } \\
\text { 'plow' }\end{array}$ \\
\hline /re / vs. /le / & $\begin{array}{l}\text { /sāṛ̂/ } \\
\text { /bār/ }\end{array}$ & $\begin{array}{l}\text { 'absence' } \\
\text { 'bring inside!' }\end{array}$ & $\begin{array}{l}\text { /sāḷ’/ } \\
\text { /bāl/ }\end{array}$ & $\begin{array}{l}\text { 'wife's brother' } \\
\text { 'ignite!' }\end{array}$ \\
\hline
\end{tabular}




\begin{tabular}{|c|c|c|c|c|}
\hline /ṭ/ vs. /ṭh/ & $\begin{array}{l}\text { /ṭok/ } \\
\text { /miṭ̄1/ } \\
\text { /kuṭ/ }\end{array}$ & $\begin{array}{l}\text { 'interrupt!' } \\
\text { 'soil' } \\
\text { 'hit!' }\end{array}$ & $\begin{array}{l}\text { /ṭhok/ } \\
\text { /miṭh̄1/ fem. } \\
\text { /uṭh/ }\end{array}$ & $\begin{array}{l}\text { 'pound!' } \\
\text { 'sweet' } \\
\text { 'get up!' }\end{array}$ \\
\hline /t/ vs. /ṭ/ & $\begin{array}{l}\text { /tāp/ } \\
\text { /nets/ } \\
\text { /it/ }\end{array}$ & $\begin{array}{l}\text { 'fever' } \\
\text { 'churning rope' } \\
\text { 'here' }\end{array}$ & $\begin{array}{l}\text { /țāp/ } \\
\text { /neṭo/ } \\
\text { /iṭ/ }\end{array}$ & $\begin{array}{l}\text { 'slipper' } \\
\text { 'a set date or time' } \\
\text { 'brick' }\end{array}$ \\
\hline /th/ vs. /th/ & $\begin{array}{l}\text { /tham/ } \\
\text { /čsth̄̄/ fem. } \\
\text { /hàth/ }\end{array}$ & $\begin{array}{l}\text { 'post, pillar' } \\
\text { 'fourth' } \\
\text { 'hand' }\end{array}$ & $\begin{array}{l}\text { /ṭhamṭhoks/ } \\
\text { /koṭhī/ } \\
\text { /gaṭh/ }\end{array}$ & $\begin{array}{l}\text { 'woodpecker' } \\
\text { 'dwelling' } \\
\text { 'knot' }\end{array}$ \\
\hline /s/ vs. /z/ & $\begin{array}{l}\text { /seāṇ/(/sīāṇ/) } \\
\text { /bastī/ } \\
\text { /das/ }\end{array}$ & $\begin{array}{l}\text { 'know!' } \\
\text { 'a settlement' } \\
\text { '10' }\end{array}$ & 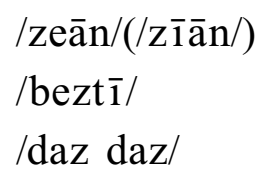 & $\begin{array}{l}\text { 'loss, damage' } \\
\text { 'a dishonor' } \\
\text { 'bang! bang!' }\end{array}$ \\
\hline /z/ vs. /d/ & $\begin{array}{l}\text { /zātīi fem. } \\
\text { /mazo/ } \\
\text { /wāz/ }\end{array}$ & $\begin{array}{l}\text { 'very own' } \\
\text { 'enjoyment' } \\
\text { 'voice' }\end{array}$ & $\begin{array}{l}\text { /dātī/ } \\
\text { /mudo/ } \\
\text { /sād/ }\end{array}$ & $\begin{array}{l}\text { 'sickle' } \\
\text { 'period of time' } \\
\text { 'taste' }\end{array}$ \\
\hline /čh/ vs. /čc/ & $\begin{array}{l}\text { /čhaṭī/ } \\
\text { /bačho/ } \\
\text { /mučh/ }\end{array}$ & $\begin{array}{l}\text { 'a wind' } \\
\text { 'calf' } \\
\text { 'moustache' }\end{array}$ & $\begin{array}{l}\text { /čațī/ } \\
\text { /bačs/ masc. } \\
\text { /muč/ }\end{array}$ & $\begin{array}{l}\text { 'loss, damage' } \\
\text { 'child' } \\
\text { 'much, many' }\end{array}$ \\
\hline$/ \check{\mathbf{c}} /$ vs. $/ \check{\mathbf{j}} /$ & $\begin{array}{l}\text { /čam/ } \\
\text { /bačā/ } \\
\text { /baṇ bič/ }\end{array}$ & $\begin{array}{l}\text { 'hide (of cattle)' } \\
\text { 'save!' } \\
\text { 'in the forest' }\end{array}$ & $\begin{array}{l}\text { /̌̆am/ } \\
\text { /bajāa/ } \\
\text { /bạ̣ bī̌/ }\end{array}$ & $\begin{array}{l}\text { 'be born!' } \\
\text { 'play instrument!' } \\
\text { 'lightning bolt' }\end{array}$ \\
\hline$/ \check{\mathrm{c}} /$ vs. $/ \check{\mathrm{s}} /$ & $\begin{array}{l}\text { /čak/ } \\
\text { /bačs/ masc. } \\
\text { /lačko/ } \\
\text { /kaḷāč/ }\end{array}$ & $\begin{array}{l}\text { 'taste' } \\
\text { 'child' } \\
\text { 'womens' cap' } \\
\text { 'cubit' }\end{array}$ & $\begin{array}{l}\text { /šak/ } \\
\text { /našs/ } \\
\text { /laške/ } \\
\text { /lāš/ }\end{array}$ & $\begin{array}{l}\text { 'guess, doubt' } \\
\text { 'drug' } \\
\text { 'lightning flashes' } \\
\text { 'corpse' }\end{array}$ \\
\hline /s/ vs. /šs/ & $\begin{array}{l}\text { /sar/ } \\
\text { /nasāṇı/ } \\
\text { /mās/ }\end{array}$ & $\begin{array}{l}\text { 'lake' } \\
\text { 'chasing, to chase' } \\
\text { 'meat' }\end{array}$ & $\begin{array}{l}\text { /šar/ } \\
\text { /našāṇı/ } \\
\text { /bidmāšs/ }\end{array}$ & $\begin{array}{l}\text { 'public matter' } \\
\text { 'aim' } \\
\text { 'criminal' }\end{array}$ \\
\hline
\end{tabular}




\begin{tabular}{|c|c|c|c|c|}
\hline $\mid \mathrm{j} /$ vs. $\mid \mathrm{z} /$ & $\begin{array}{l}\text { /guǰar/ } \\
\text { /bāj̄̄i/ } \\
/ \text { dāāj/ }\end{array}$ & $\begin{array}{l}\text { 'Gujar' } \\
\text { title for men } \\
\text { 'dowry' }\end{array}$ & $\begin{array}{l}\text { /guzar/ } \\
\text { /rāzī/ } \\
\text { /bāz/ }\end{array}$ & $\begin{array}{l}\text { 'pass!' } \\
\text { 'happy' } \\
\text { 'butterfly' also 'eagle' }\end{array}$ \\
\hline$/ \mathrm{j} /$ vs. $/ \mathrm{d} /$ & 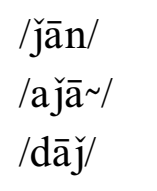 & $\begin{array}{l}\text { 'life, soul' } \\
\text { 'right now' } \\
\text { 'dowry' }\end{array}$ & $\begin{array}{l}\text { /dānd/ } \\
\text { /addā/ } \\
\text { /imdād/ }\end{array}$ & $\begin{array}{l}\text { 'ox' } \\
\text { 'Father!' } \\
\text { 'help' }\end{array}$ \\
\hline$/ \breve{j} /$ vs. $/ \mathrm{y} /$ & $\begin{array}{l}/ \text { jāị } / / \\
/ \text { dā } / /\end{array}$ & $\begin{array}{l}\text { 'net' } \\
\text { 'dowry' }\end{array}$ & $\begin{array}{l}\text { /yār/ } \\
\text { /nāy/ }\end{array}$ & $\begin{array}{l}\text { 'friend' } \\
\text { 'barber' }\end{array}$ \\
\hline /y/ vs. /yy/ & $\begin{array}{l}\text { /pāyo/ [ } \\
\text { /sāyo/ [? }\end{array}$ & $\begin{array}{l}\text { 'furniture leg' } \\
\text { 'shadow' }\end{array}$ & $\begin{array}{l}\text { /pāyys/ } \\
\text { /māyys }\end{array}$ & $\begin{array}{l}: 0] \text { 'grazing fee' } \\
y: 0] \text { 'kind of song' }\end{array}$ \\
\hline
\end{tabular}

\subsubsection{Distribution}

There are no general restrictions on the distribution of the dental area stops, affricates, and fricatives (but note MacEachern's (1997) restriction for aspirated stops in 2.1.5.1). Initial sequences of consonant $+/ \mathrm{y} /($ represented as $\mathrm{Cy})$ are realized as phonetic

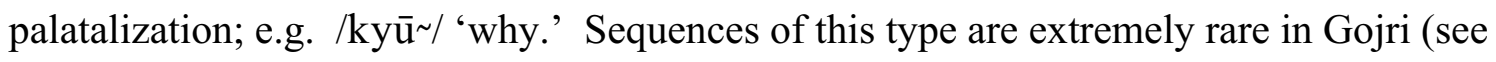
also 2.3.3).

(16) Distribution of dental area stops, affricates, and fricatives initial intervocalic final

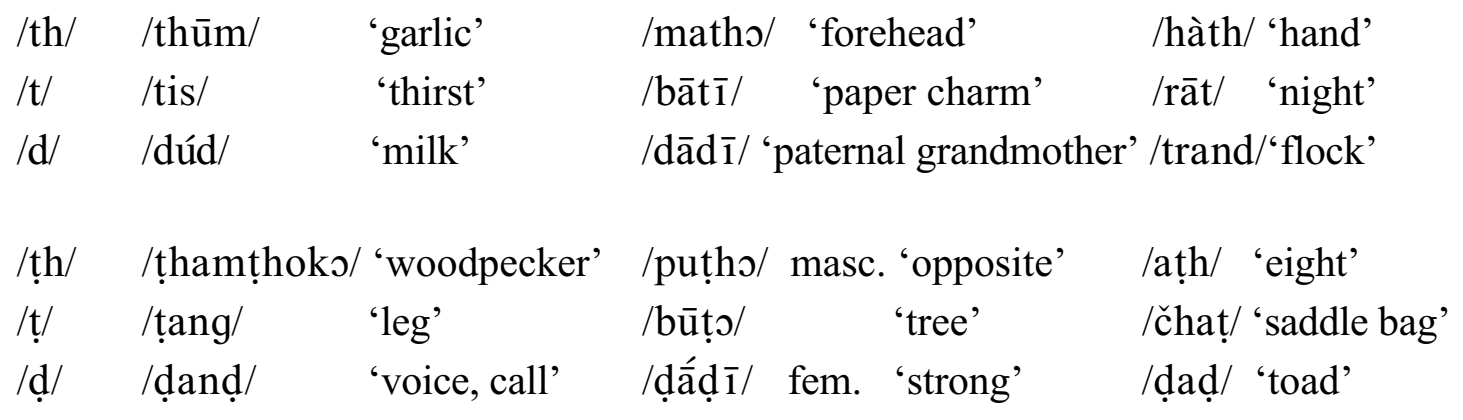




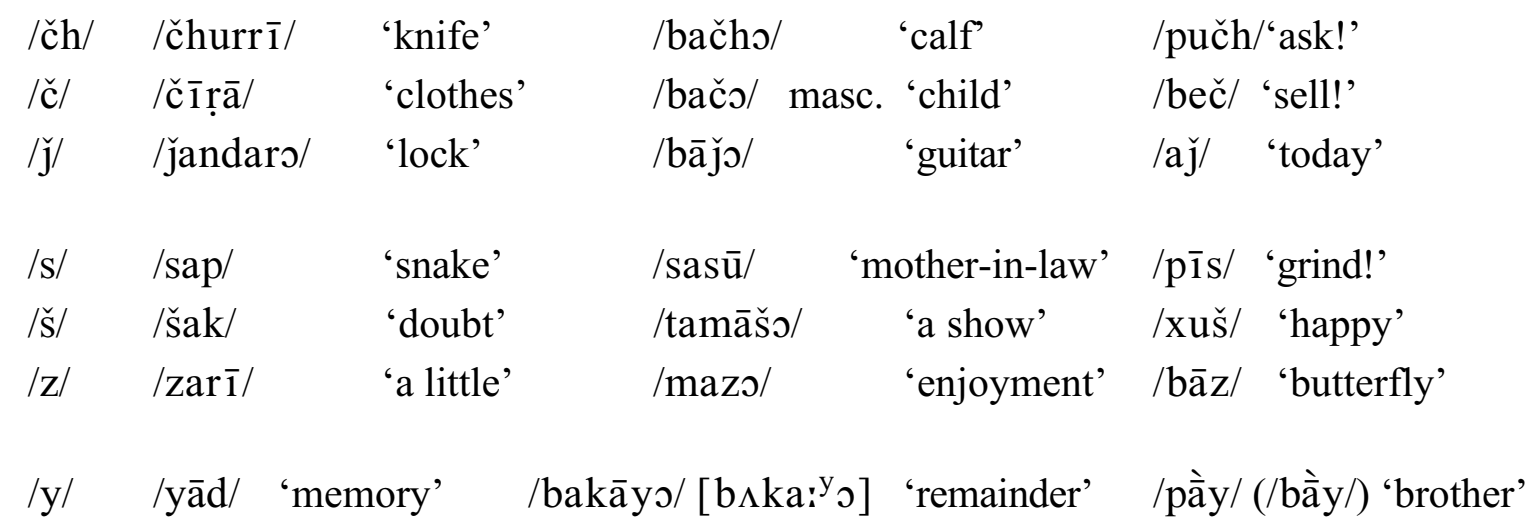

\subsubsection{Variation}

Often the Western cognates of Eastern words featuring medial or final /z/ are instead pronounced with $/ \check{\mathrm{j}} /$ :

(17) Correspondence of Western $/ \mathfrak{j} /$ to Eastern $/ \mathbf{z} /$

\begin{tabular}{|c|c|c|}
\hline Eastern & Westerr & \\
\hline /peāz/ & $/ p \overline{1} \bar{a} \mathbf{j} /$ & 'onion' \\
\hline /rozo/ & /roǰs/ & 'ritual fast' \\
\hline /gaz/ & /gaǰ/ & 'one meter' \\
\hline
\end{tabular}

One interesting counterexample to this pattern is the Western pronunciation of the Kashmiri city of Rajauri, /razorī1/, which Eastern speakers pronounce as /raǰrī1/.

\subsubsection{Velar Area Stops and Fricatives}

The characteristic three-way opposition noted earlier is attested in the velar area by $/ \mathrm{kh} /, / \mathrm{k} /$, and $/ \mathrm{g} /$. The velar fricatives $/ \mathrm{x} /$ and $/ \mathrm{y} /$ are of foreign origin but by no means rare. The voiceless glottal fricative $/ \mathrm{h} /$ is always associated with low tone on the following vowel. It contrasts in initial position with words beginning with glottal stop [?] followed by a vowel. 


\subsubsection{Contrast}

(18) Velar area phonemic contrasts

\begin{tabular}{|c|c|c|c|c|}
\hline /kh/ vs. /k/ & /kham/ & 'feather' & /kam/ & 'work' \\
\hline & /likh/ & ‘write!' & /lik/ & 'lap up (water or milk)!' \\
\hline /k/ vs. /g/ & /kors/ & 'frost' & /gors/ & 'white man' \\
\hline & /čok/ & 'intersection' & /čog/ & 'bird food (regurgitated)' \\
\hline$/ g /$ vs. $/ \mathrm{\gamma} /$ & /gam/ & 'deep crevasse' & /yam/ & 'worry, care' \\
\hline & /nāg/ & 'cobra' & /bāy/ & 'garden' \\
\hline /y/ vs. /x/ & /yer/ & 'other, strange' & /xer/ & 'it's OK' \\
\hline & /šuyal/ & 'fun' & /buxārī/ & 'chimney' \\
\hline /x/ vs. $/ \mathrm{kh} /$ & /xān/ & 'Khan' (a title) & /khāṇ/ & 'a mine' \\
\hline & $/ \mathrm{mex} /$ & 'nail' & /dekh/ & 'look!' \\
\hline$/ \mathrm{h} /$ vs. $\emptyset$ & /hàḍ̂̄/ & 'bone' & $/ \operatorname{aḍ} \overline{1} / \quad[2 \Lambda$ dị $]$ & 'heel' \\
\hline & /hànḍ̂ $\overline{1} /$ & 'clay pot' & 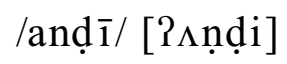 & 'physique' \\
\hline & /hạ̀̀/ & 'plow' & /āḷ/ [?a:ḷ] ] & 'one who ...' \\
\hline
\end{tabular}

\subsubsection{Distribution}

The fricative $/ \mathrm{h} /$ occurs only in initial position. The other velar area phonemes have no general distributional restrictions, although MacEachern (1997:58) finds that, while initial /h/ may cooccur with aspirated stops in words, 'there is only one aspirated stop per word, unless the aspirated stops are identical.' Thus $/ \mathrm{kh} /$ may occur with $/ \mathrm{h} / \mathrm{or}$ another $/ \mathrm{kh} /$, but not with /ph/, /th/, /čh/, or /țh/. I have not found any counterexamples in my own data. 
(19) Distribution of velar area phonemes

\begin{tabular}{|c|c|c|c|c|}
\hline initial & & intervocal & & final \\
\hline /khoro/ & masc. 'rough' & /čarkho/ & 'spinning wheel' & /akh/ 'eye' \\
\hline /kuts/ & masc. 'dog' & /kāko/ & 'paternal uncle' & /nak/ 'nose' \\
\hline$/ g \overline{\mathrm{a}} \sim /$ & 'cow' & / $\operatorname{dog} \overline{1} /$ & ‘field' & 'fire' \\
\hline /yolel/ & 'slingshot' & /yoȳā/ & 'noise' & /dấy/ 'stain' \\
\hline /xat/ & 'letter' & /buxārī/ & 'chimney' & /mex/ 'nail' \\
\hline /hàți/ & 'shop' & & & ---" \\
\hline
\end{tabular}

\subsubsection{Variation}

In the normal speech of most Gujars, the $/ \mathrm{g} /$ in any final $/ \mathrm{ng} /$ cluster is unpronounced. For example, /rang/ 'color' is articulated as [ray]; /mang/ 'beg!' is articulated as [may].

The sub-phonemic glottal stop [?] is most readily observed in the negative response to a yes-no question, $/ \mathrm{na} /[\mathrm{n} \Lambda$ ?] 'no'. It also precedes any word-initial vowel that is not also low tone, i.e. it occurs wherever $/ \mathrm{h} /$ does not. The fricativation of $/ \mathrm{h} /$ is very faint, and is reduced to inaudible in all words like /hàvā/ [ə̀vă:] 'wind' in which the first syllable is unstressed (see 3.1.2.5.3).

\subsubsection{Gemination}

Gemination, the doubling of consonants, has phonemic status in Gojri. Geminated segments are difficult for the non-native speaker to distinguish from their non-geminated counterparts without contrastive data.

(20) Contrasts between geminated and non-geminated consonants /ammā (ko)/ '(of) Mother' (the final vowel in 'Mother' is phonetically nasalized)

vs. /amā $(\mathrm{ks}) /$ '(of) mangoes' 


$\begin{array}{lll} & \text { /dabbo/ masc. 'spotted' } \\ \text { vs. } & \text { 'dabox' } \\ & \text { /addə/ } & \text { 'Father' } \\ \text { vs. } & \text { /ádə/ } & \text { masc. 'half' } \\ & & \\ & \text { /allā/ } & \text { 'Allah' } \\ \text { vs. } & \text { /hàlā/ } & \text { 'Oh! Wow!' }\end{array}$

Other words featuring geminated consonants include /anno/ 'blind man', /čhakkor/ 'bread basket', and /čhittar/ 'kind of shoe'.

\subsection{Gojri Vowel Phonemes}

Both the Kaghani and Allaiwal dialects of Gojri have ten vowel phonemes, which are equivalent to those of Urdu and Punjabi. Gojri /e/ is lower than the [e:] of wellenunciated Urdu. An eleventh vowel, the marginal [æ], occurs rarely in English loans such as [kæmp] 'camp' and [bæg] 'duffel bag'.

$\underline{\text { Oral Vowels }}$

The oral vowel phonemes of Gojri are shown in Table 2.

Table 2. Gojri Oral Vowel Phonemes

$\begin{array}{lccc} & \text { front } & \text { central } & \text { back } \\ \text { close } & \overline{1} & & \overline{\mathrm{u}} \\ \text { close-mid } & \mathrm{e}^{\mathrm{i}} & & \mathrm{u} \\ \text { open-mid } & \varepsilon & \mathrm{a} & \mathrm{o} \\ \text { open } & & & \mathrm{o}\end{array}$


Six vowel phonemes comprise three 'short/long' vowel pairs: /a/ [ $\Lambda]$ and /âa/ [a: ], /i/ [I] and $/ \overline{\mathbf{1}} /[\mathrm{i}:], / \mathrm{u} /[\mathrm{U}]$ and $/ \overline{\mathrm{u}} /[\mathrm{u}:]$. The close back vowels $/ \mathrm{u} /$ and $/ \overline{\mathrm{u}} /$ differ only in length, while the members of the other pairs are distinguished primarily by differences in length but also by quality differences. The remaining vowel phonemes are all phonologically

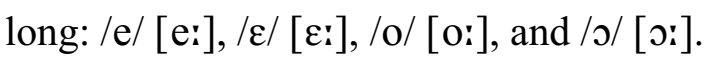

The vowels / $\varepsilon /$ and / $/$ / correspond to the monophthongized diphthongs transcribed for Hindi-Urdu as /ai/ and /au/, respectively (Masica 1991:110-111). The latter representations are problematic for Gojri, however. The distribution of $/ \varepsilon /$ is not limited to lexical roots as in Urdu, but rather extends to key grammatical morphemes such as the locative case marker and third person singular agreement marker (where Urdu has /e/). Using /ai/ would falsely imply that these markers had a historical diphthongal connection when in fact they are cognate with /e/. Likewise, while Gojri /o/ occurs in many of the same roots where it occurs in Urdu, it also figures prominently as the nominative masculine singular agreement marker within the noun phrase and as a verbal suffix for certain stems ending in a vowel. Using /au/to represent $/ \mathrm{s} /$ in such cases would be both misleading and awkward. ${ }^{1}$ These decisions have no bearing on the Gojri representations of these vowels, which are identical to their representations in Urdu.

The ten phonemic Gojri vowels contrast in monosyllables beginning with $/ \mathrm{m} /$ and closing with the liquids $/ 1 /, / 1 /$ or $/ \mathbf{r} /$ as shown in (21):

(21) Phonemic vowel contrasts

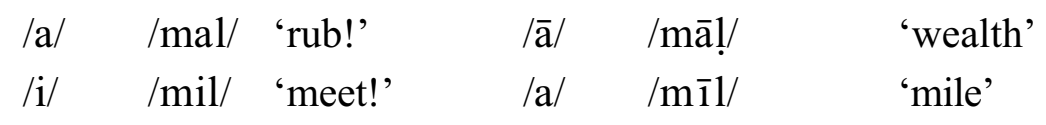




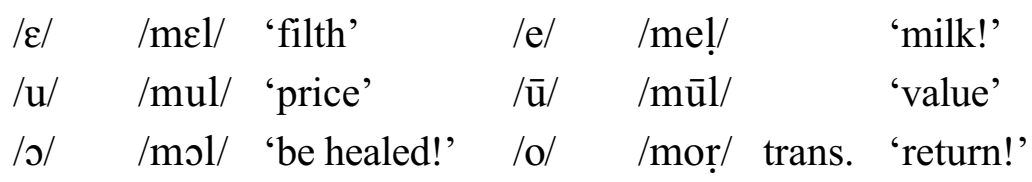

The contrast between /o/ and /o/ is particularly difficult to hear, especially in the Western dialect where / $/$ / is less open than in Eastern. Some helpful contrasts are shown in (22).

(22) Differentiation of $/ \mathrm{o} /$ and $/ \mathrm{o} /$

$\begin{array}{ll}\text { /do so do/ } & \text { 'two hundred two' } \\ \text { /do so réā/ (/do so ríâa/) } & \text { 'two [men] went to sleep' } \\ \text { /sodo/ } & \text { 'groceries' } \\ \text { /us ko do so rupáyyo/ } & \text { 'his two hundred rupees' } \\ \text { /kó/ } & \text { 'slaughter!' } \\ \text { /kó/ } & \text { 'say!' }\end{array}$

In addition, each of the seven Gojri long vowels has a phonemic nasalized long vowel counterpart. Where nasalized short vowels are noted in the phonetic data, their nasality is always due to environmental conditioning. This accords with Ohala's (1983) analysis for Hindi, endorsed by Masica (1991:117). The nasalized long vowels often occur in grammatical morphemes, as we shall see in Chapter 4.

Nasalized Vowels

The nasalized vowel phonemes of Gojri are shown in Table 3. Table 3. Gojri Nasalized Vowel Phonemes front central back

$\begin{array}{lccc}\text { close } & \overline{1}^{\sim} & \overline{\mathrm{u}}^{\sim} \\ \text { close-mid } & \mathrm{e}^{\sim} & & \mathrm{O}^{\sim} \\ \text { open-mid } & \varepsilon^{\sim} & & 0^{\sim} \\ \text { open } & & \overline{\mathrm{a}}^{\sim} & \end{array}$


The contrast between /e / and / $/ \varepsilon^{\sim}$ in my data is very tentative. It seems that /e/ might be lowered to $/ \varepsilon /$ due to the effects of nasalization. For this reason it is difficult to tell even if the ergative postposition should be transcribed as /ne/ (Sharma 1982) or as /ne/ per the standard Urdu transcription.

\subsubsection{Contrast}

(23) Short versus long vowels

\begin{tabular}{|c|c|c|c|c|}
\hline /a/ vs. /ā/ & $\begin{array}{l}\text { /rat/ } \\
\text { /kare } /\end{array}$ & $\begin{array}{l}\text { 'blood' } \\
\text { 'wood pile' }\end{array}$ & $\begin{array}{l}\text { /rāt/ } \\
/ k \bar{a} r ̣ /\end{array}$ & $\begin{array}{l}\text { 'night' } \\
\text { 'rocky place' }\end{array}$ \\
\hline /i/ vs. $/ \overline{\mathbf{1}} /$ & $\begin{array}{l}\text { /giṭh/ } \\
\text { /bi j// }\end{array}$ & $\begin{array}{l}\text { 'handspan' } \\
\text { 'lightning bolt' }\end{array}$ & $\begin{array}{l}/ g \overline{1} t /(/ g \overline{1} d /) \\
/ b \overline{1} \breve{j} /\end{array}$ & $\begin{array}{l}\text { 'song' } \\
\text { 'seed' }\end{array}$ \\
\hline$/ \mathrm{u} /$ vs. $/ \overline{\mathrm{u}} /$ & $\begin{array}{l}\text { /čup/ } \\
/ \text { pučh/ }\end{array}$ & $\begin{array}{l}\text { 'hush!' } \\
\text { 'ask!' }\end{array}$ & $\begin{array}{l}\text { /čūp/ } \\
\text { /pūčh/ }\end{array}$ & $\begin{array}{l}\text { 'suck!' } \\
\text { 'clean!' }\end{array}$ \\
\hline
\end{tabular}

(24) Contrasts between qualitively adjacent vowels

\begin{tabular}{|c|c|c|c|c|}
\hline /a/ vs. /i/ & $\begin{array}{l}/ \text { nač/ } \\
/ \operatorname{las} \overline{1} /\end{array}$ & $\begin{array}{l}\text { 'dance!' } \\
\text { 'buttermilk' }\end{array}$ & $\begin{array}{l}\text { /ničh/ } \\
/ \text { lis } \overline{1} / \text { fem. }\end{array}$ & $\begin{array}{l}\text { 'sneeze!' } \\
\text { 'weak' }\end{array}$ \\
\hline /a/ vs. / $/ \varepsilon /$ & $\begin{array}{l}\text { /bas/ } \\
\text { /hàl/ intrans. }\end{array}$ & $\begin{array}{l}\text { 'enough!' 'dwell!' } \\
\text { 'shake!' }\end{array}$ & $\begin{array}{l}\text { /bes/ } \\
\text { /hèl/ }\end{array}$ & $\begin{array}{l}\text { 'sit!' } \\
\text { 'get used to!' }\end{array}$ \\
\hline /o/ vs. /u/ & $\begin{array}{l}\text { /mol/ } \\
\text { /póč/ }\end{array}$ & $\begin{array}{l}\text { 'be healed' } \\
\text { 'arrive!' }\end{array}$ & $\begin{array}{l}/ \mathrm{mul} / \\
/ \mathrm{pučh} /\end{array}$ & $\begin{array}{l}\text { 'price' } \\
\text { 'ask [question]!' }\end{array}$ \\
\hline /a/ vs. /u/ & /mandr $\overline{1} /$ fem & 'low' & /mundrī/ & 'earring' \\
\hline /e/ vs. $/ \overline{1} /$ & /ǰéb/ (/ǰeb/) & 'pocket' & / jó & 'tongue' \\
\hline /o/ vs. /u/ & $\begin{array}{l}\text { /ṭor/ } \\
\text { /mor/ trans. }\end{array}$ & $\begin{array}{l}\text { 'drive [cattle]!' } \\
\text { 'return!' }\end{array}$ & $\begin{array}{l}\text { /ṭur/ } \\
\text { /muṛ / intrans. }\end{array}$ & $\begin{array}{l}\text { 'walk!' } \\
\text { 'return!' }\end{array}$ \\
\hline /o/ vs. $/ \overline{\mathrm{u}} /$ & /čorī1/ & 'stealing' & /čūrīi / & 'dipping bread it \\
\hline
\end{tabular}


/e/ vs. /e/ / / ke/ locative postposition/ conjunctive participle

$\begin{array}{ll}/ \text { te/ } & \text { 'and' } \\ \text { /mero/ } & \text { 'big field' }\end{array}$

/o/ vs. /o/

$\begin{array}{ll}\text { /kó/ } & \text { 'say!' } \\ \text { /so/ } & \text { 'one hundred' } \\ \text { /bóto/ } & \text { 'security' }\end{array}$

(25) Oral versus nasalized vowels

$/ \bar{a} /$

vs. $/ \bar{a} \sim /$
/dā/
'method'
/terā/ masc.sg. 'your'

$/ \overline{1} /$ vs. $/ \overline{1} \sim / \quad / \operatorname{las} \overline{1} /$

'buttermilk'

/e/ vs. /e / /ise/

/peš/

/E/ vs. $/ \varepsilon^{\sim /} /$ čale/

/te/

$/ \overline{\mathrm{u}} /$ vs. $/ \overline{\mathrm{u}} \sim / \quad / \mathrm{j} \overline{\mathrm{u}} /$

/o/ vs. /o / / /ní hòse/

/o/ vs. /0 / /Xof/ /ke/ 'what?' / complementizer 'that'

/te/ ablative postposition

/mero/ masc. 'my'

/kó/ 'slaughter!'

/so/ 'sleep!'

/bóț̄i ' 'bride'

\begin{tabular}{|c|c|c|c|c|c|}
\hline /e/ vs. /e / & /pešs/ & 'this very one' & $\begin{array}{l}/ \text { /ise / } \\
\text { /nasāpe / } \\
/ \mathrm{e}^{\sim} \sim \check{\mathrm{S}} /\end{array}$ & $\begin{array}{l}\text { 'this one did' } \\
\text { 'suddenly' } \\
\text { 'enjoyment' }\end{array}$ & W.only \\
\hline /E/ vs. / / $\sim /$ & /čale/ & 'he goes' & /čale / & 'they go' & E.only \\
\hline & $/ \mathrm{t} \varepsilon /$ & 'and' & $/ \mathrm{t} \varepsilon^{\sim} / \mathrm{sg}$. & 'you did' & \\
\hline$/ \overline{\mathrm{u}} / \mathrm{vs} . / \overline{\mathrm{u}} \sim /$ & $/ \check{\mathrm{j}} \overline{\mathrm{u}} /$ & 'fodder' & $/ \check{\mathrm{j}} \overline{\mathrm{u}} \sim /$ & 'lice' & \\
\hline /o/ vs. /o / & /ń́ hòse/ & 'won't be' & /hò S/ & 'interest' & \\
\hline /0/vs. /0 / & /xof/ & 'fear' & $/ \mathrm{s} \boldsymbol{o}^{\sim \mathrm{f} /}$ & 'anise' & \\
\hline
\end{tabular}

\subsubsection{Distribution}

The only restriction on vowel occurrence is that there is generally no phonemic contrast between short/long pairs in final position, i.e. /i/ and /u/ do not occur wordfinally and /a/ occurs word-finally only in the third person feminine singular pronouns. 
(26) Distribution of vowels in words

Initial Medial Final

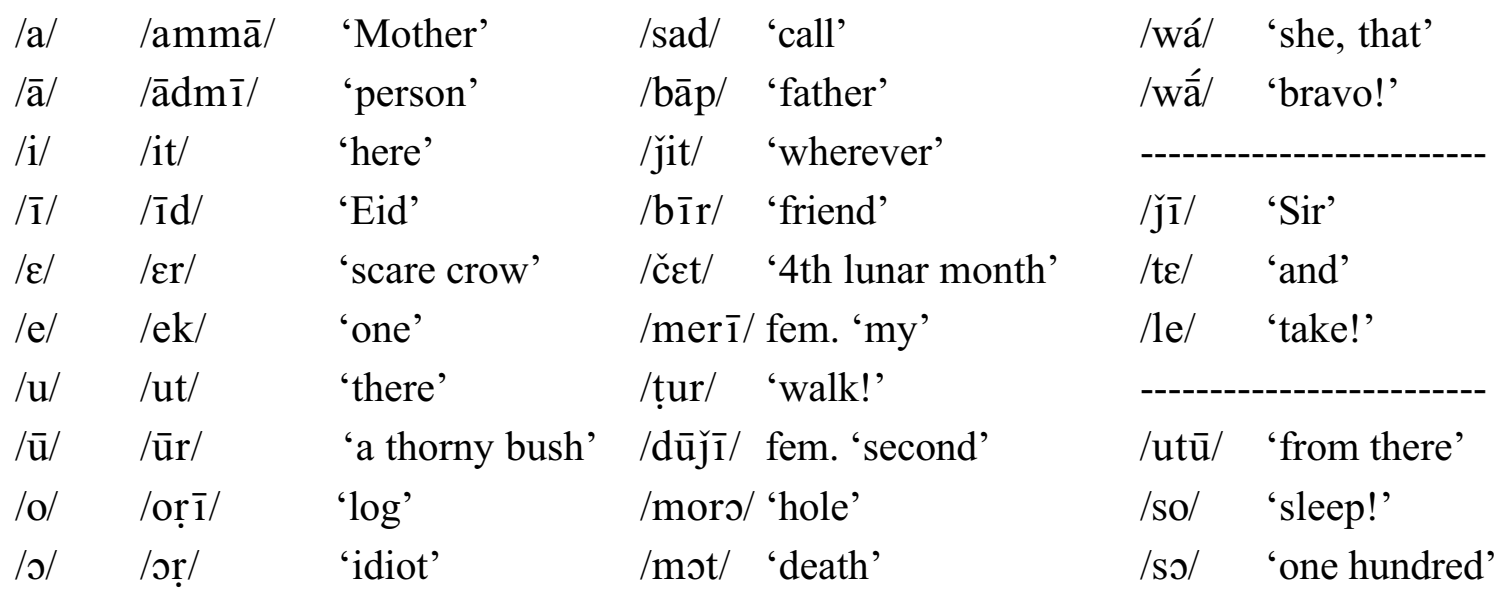

\subsubsection{Variation}

In unstressed syllables of disyllabic words lacking suffixation, the short vowels /a/ [ə] and $/ \mathrm{u} /[\mathrm{U}]$ are in free variation. Most often this involves words ending in the liquids $/ \mathrm{r} /$, $/ \mathrm{r} /$, and $/ \mathbf{l} /$. Vowel harmony may play a role in determining which variant will occur most often for a given word. In phonemic representation, /a/ is tentatively preferred. This is another decision that has no impact on Gojri spellings, since unstressed stem vowels are not normally written.

(27) Variation of $/ \mathrm{u} /$ and $/ \mathrm{a} /$ in unstressed syllables

\begin{tabular}{|c|c|c|}
\hline /kukaṛ/ 'chicken' & ['kukur] & or ['kukə̣, $]$ \\
\hline 'thanks' & ['sukur] & or ['šukər] \\
\hline /čokar/ & ['čo:kur] & or ['čo:kər] \\
\hline 'above' & {$\left[{ }^{\prime} \Lambda\right.$ pur $]$} & or $\left[{ }^{\prime} \Lambda\right.$ pər $]$ \\
\hline /brābar/ 'equal' & ['bra:bur] & or ['bra:bər] \\
\hline /gidar/ 'jackal' & ['gidur] & or ['gidər] \\
\hline /mačhar/ 'mosquito' & ['m $\mathrm{m}$ čhur] & or $\left[{ }^{\prime} \mathrm{m} \Lambda\right.$ čhər $]$ \\
\hline /ǰusam/ 'body' & ['ǰusum] & or ['̌̌usəm] \\
\hline
\end{tabular}




$$
\begin{array}{ll}
\text { /badal/ 'rain' ['badul] } & \text { or ['badəl] } \\
\text { /čittar/ 'kind of shoe' ['čIt:ur] } & \text { or ['čIt:ər] }
\end{array}
$$

For certain words like the Perso-Arabic loan /hàfāzat/ 'protection', an /u/ pronunciation in the final syllable is incorrect.

Utterance-final vowels, along with any consonants immediately preceding them, are frequently devoiced. Most often these are vowel suffixes on nouns and verbs. For example, in perfective constructions involving transitive verbs the auxiliary verb /čhur / 'drop', along with any inflectional endings, is often completely devoiced. In feminine nouns, the effect of this devoicing can be the production of a voiceless palatal fricative, [ç] in the IPA transcription, at the point where the feminine suffix $/ \overline{1} /$ devoices.

Any vowel immediately following a nasal consonant will also become nasalized. This generalization does not extend to vowels following the so-called 'nasal clusters.'

\subsection{Phonotactics}

\subsubsection{Syllable Types}

The most basic Gojri syllable type consists of a consonantal onset (C) and a shortvowel nucleus (V), and is represented abstractly as CV. This type of syllable rarely occurs as a word by itself, i.e. as a monosyllabic word. One example is the proximate third singular feminine pronoun /yá/ 'she, this.' A syllable consisting only of a shortvowel nucleus (V) may also occur, but only in polysyllabic words like /ugàrị̂̄ fem. 'naked' shown in (29) below. Monosyllabic words featuring a consonantal onset (C) and a long-vowel nucleus (VV), represented as CVV, are quite common. Some examples of such CVV monosyllables are the number/do/ [do:] 'two', and the verb /pī/ 'drink!' In a very few cases, a long-vowel nucleus monosyllable occurs without an onset. The only 
two examples of such $\mathrm{VV}$ monosyllables in my database are the vocative interjection $/ \mathrm{J} /$ [o:] 'Oh', and the distal third masculine singular variant /ó/ [ô:] 'he, that.'

Two other syllable types, CVC and CVVC, feature both an onset and consonantal coda (C) after the vowel nucleus. Syllables having a coda are called 'closed', while those lacking a coda are called 'open' (a term relevant to the following discussion of verb stems). Some examples of CVC monosyllables are /bič/ 'in' and /kam/ 'work.' Some examples of CVVC monosyllables are /lūṇ/ 'salt' and /mès/ [měss] 'buffalo.' Examples of closed monosyllables include the VC /it/ 'here' and /ut/ 'there', and the VVC /ek/ [e:k] 'one' and /oṛ / [orṛ] 'idiot.'

Sequences of two consonants may also occur in the onset and coda of syllables, without any intervening vowel. Such onsets and codas, represented as CC, expand the inventory of syllable types to include those shown in (28).

$$
\text { Syllable Types Featuring CC Sequences }
$$

$\begin{array}{lll}\text { CCVCC } & \text { /trand/ 'flock' } & \text { /kranḍ/ 'silo' } \\ \text { CCVC } & \text { /srạ̣/ 'hay' } & \text { /prat/ 'turn over!' } \\ \text { CCVV } & \text { /grā / 'village' } & \text { /kyū / 'why' } \\ \text { CCVVC } & \text { /khwā! / 'feed!' } & \text { /tror / 'break off!' } \\ \text { CVCC } & \text { /bast/ 'jewelry' } & \text { /dand/ 'tooth' } \\ \text { CVVCC } & \text { /dānd/ 'ox' } & \text { /šārk/ 'mina bird' }\end{array}$

The types CCV and CCVVCC are not attested in my data.

All polysyllabic Gojri words may be analyzed as combinations of the syllable types described above. A partial list of possible syllable patterns is shown in (29). 
(29) Syllable patterns in polysyllabic words

\begin{tabular}{|c|c|}
\hline V.CVV & /itār/'Sunday' \\
\hline V.CVV.CVV & /ugà̀r̄îl fem. 'naked' \\
\hline VC.CVV & /ačb $\overline{1} /$ 'exhaustion, discomfort' \\
\hline VC.CVVC & /absos/ 'sadness' \\
\hline CV.CV.CVV & /kìgaro/ (/gìgaro/ ) 'a kind of frock' \\
\hline CV.CVV & /tùn̄̄/ (/dùn̄̄i)'navel' \\
\hline CV.CVV.VV & /babúo/ 'spider' \\
\hline CV.CVV.VC & /maleàp/ 'worm' \\
\hline CV.CVV.VVC & /pìgeāṛ/ (/bìgīāṛ̂) ‘wolf’ \\
\hline CV.CVV.CVV & /kasì̀ț̄ī'ccrawling' \\
\hline CV.CVC & /mazab/ 'religion' \\
\hline CV.CVVC & /paṛà̀s/ (/baṛà̀s/) ‘steam’ \\
\hline CVV.VV & /pīe/ '(s)he drinks' \\
\hline CVV.CVC & /kà̀bar/ (/gà̀bar/) 'be fearful!' \\
\hline CVV.CVV & /mìno/ 'month' \\
\hline CVV.CVV.VVC & /dādeạ̀̀! 'paternal relatives' \\
\hline CVV.CVVC & /dopấir/ (/dopấr/) 'noon’ \\
\hline CVV.CCVV & /kà̀brā/ (/gà̀brā/) 'cause to worry!' \\
\hline CCVV.CVV & /swà̀gā/ ‘ashes’' \\
\hline CVC.CVV & /barkàà trans. 'boil!' \\
\hline CVC.CVC & /čhittar/ 'kind of shoe' \\
\hline CVC.CVVC & /budwà̀r/ 'Wednesday’ \\
\hline CVC.CVV.CVV & /hàmzoḷ/ masc. 'age mate' \\
\hline
\end{tabular}

The syllable structure of a word can be altered through inflection. In words structured 'CV.CVC (or similarly), the unstressed vowel of the CVC syllable elides upon the addition of an inflectional affix (cf. Masica 1991:227) and the result is a word of type CVC.CVV. For example, when affixed with the plural oblique before a postposition, /āfas/ 'office' becomes /āfsā̃ (mā)/ '(in) offices' and / jatak/ 'child' becomes /jatkā̃ (nā)/ '(to) children.' The same elision is observed for the addition of the causative suffix /-āa. Compare /(bāl) katar/ 'cut (hair)!' to /(bāl) katrā/ 'get someone to cut (hair)!' 


\subsubsection{Consonant Clusters}

In Gojri words, two consonants may occur together in sequence or 'cluster' without any intervening vowel. Initial clusters are relatively uncommon. Only the consonants $/ \mathrm{r} /$, /w/, /y/ and /l/ (e.g. /blādrī/ 'clan') can occur as the second member of an initial cluster, although due to loans like /skūl/ 'school' this set may be slightly expanded (but note the variant [s $\mathrm{k}$ ku:l] ). Consonants which cannot occur as the first member of an initial cluster are /r/, /w/, /y/, /h/ and the non-initial retroflexes /ṇ/, /ṛ/, and /ḷ My database contains words in which the following occur as the first member of initial clusters: /p/, /b/,

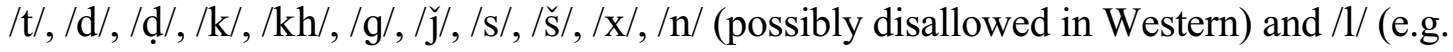
/lwā/ 'dress (someone else)!'). In addition, Gujars have no trouble pronouncing the name

of the Perso-Arabic letter /zwād/. Presumably other stops, fricatives, and affricates may also occur as the first member, although it seems unlikely that many examples could be found for $/ \mathrm{f} /$ and the nasal $/ \mathrm{m} /$.

Final consonant clusters are only slightly more common, the difference being due to the frequency of nasal clusters (which do not occur initially). Generally speaking, the first member of a final cluster must be a nasal (other than $/ \mathrm{m} /$ ) or a continuant, and the second member must be a stop, fricative, or affricate (provided it otherwise occurs wordfinally). The fricatives /f/, /s/, and /šs may therefore occur in either position.

Except for those clusters which also occur word-initially, medial clusters, including nasal clusters, occur across syllable boundaries.

\subsubsection{Vowel Sequences (Hiatus)}

Vowel sequences involving two syllables within Gojri lexical roots are the exception. Two such sequences, /oā/ and /es/, are attested by one word each in my database: /roāj/ 


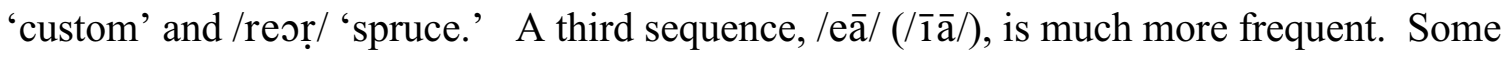
examples are /dèāṛo/ (/dì̄āṛo)‘day’, /seāḷ (/seāḷ/) ‘winter’, and /bideā/ (/bidīāa) ‘a

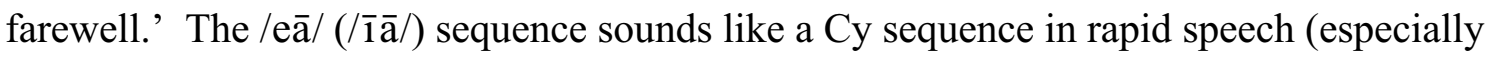
in Western), but in deliberate speech sounds quite different from a true Cy sequence such as that in the word $/ \mathrm{ky} \overline{\mathrm{u}} \sim /$ 'why', i.e. it is syllabified, and there is a clear /e/ vs. $/ \overline{\mathbf{1}} /$ quality contrast between the Eastern and Western varieties. In longer words like /pì gēāṛ/

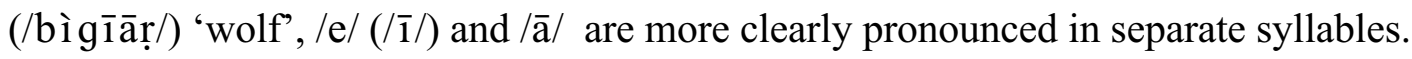

A large number of vowel sequences may occur across morpheme boundaries. Normally these involve two syllables; however, the suffixes $/ \overline{\mathbf{1}} /, / \overline{\mathrm{u}} \sim /$, or $/ \mathrm{e} /$ may result in monosyllabic sequences. What is claimed in (30) and below for any level-tone oral vowel is also true for any nasalized or high-tone counterpart.

(30) Vowel sequences across morpheme boundaries (the second vowel is suffixal)

\begin{tabular}{|c|c|c|c|}
\hline Sequence & Example & Numbe & llables pronounced \\
\hline$/ \mathrm{a} \overline{1} /$ & /gāî/ & 'she went' & one \\
\hline$/ \overline{\mathrm{a}} \overline{\mathrm{u}} \sim /$ & $/ \bar{a} \bar{u} \sim /$ & 'I come' & one \\
\hline$/ \overline{\mathrm{a}} \overline{\mathbf{1}} /$ & $/ \overline{\mathrm{a}} \overline{\mathbf{1}} /$ & 'she came' & one \\
\hline$/ \overline{\mathrm{a} e} /$ & /kāe/ & indef.fem.sg. pronoun & one \\
\hline$/ \bar{a} \varepsilon /$ W. only & $/ \bar{a} \varepsilon /$ & '(s)he comes’' & two \\
\hline /āo / W. only & $/ \bar{a} \jmath^{\sim} /$ & 'you (pl.) come!' & two \\
\hline$/ \overline{\mathrm{u}} \overline{1} /$ & /sūîl/ & 'needle' & two \\
\hline$/ \overline{\mathrm{u}} \mathrm{s} /$ & /mūo/ masc.sg. & 'dead' & two \\
\hline$/ \overline{\mathrm{u}} \overline{\mathrm{a}} /$ & masc.pl. & 'dead' & two \\
\hline$/ \overline{1} \jmath /$ & masc.sg. & 'took' & two \\
\hline$/ \overline{1} \overline{\mathrm{a}} \sim /$ & masc.pl. & 'drank' & two \\
\hline$/ \overline{1} \overline{\mathrm{u}} /$ & $/ p \overline{1} \overline{\mathrm{u}} \sim /$ & 'I drink' & two \\
\hline$/ \overline{1} \varepsilon /$ & /pī $\varepsilon /$ & '(s)he drinks' & two \\
\hline$/ \overline{1} \mathrm{e} /$ & $/ \overline{\mathrm{a}} \overline{\mathbf{1}} \mathrm{e} /(/ \overline{\mathrm{a}} \overline{1} \sim \mathrm{e}) /$ fut. & 'come!' & two \\
\hline /ō̄̄/ & /soā / & 'we sleep' & two \\
\hline
\end{tabular}




\begin{tabular}{|c|c|c|c|c|}
\hline /oe/ & /doe/ & & 'both' & two \\
\hline /ōî/ & /kōi/ & fem.sg. & 'slaughtered' & one \\
\hline /oe/ & /soe/ & & '(s)he sleeps' & two \\
\hline /oo/ & /noo/ & masc.sg. & 'new' & two \\
\hline /oū $/$ & $/ \operatorname{sou}^{\sim} /$ & & 'I sleep' & two \\
\hline /eā $/$ & E. only /leā $\sim /$ & & 'we take' & \\
\hline /eq/ & E. only /lee/ & & '(s)he takes' & two \\
\hline /eo/ & E. only /des/ & & 'you pl. give!' & two \\
\hline /عe/ & $/ \operatorname{trce} /$ & & 'all three' & \\
\hline
\end{tabular}

Certain cases of hiatus are resolved by epenthesis. The examples in (31) show an epenthetic /w/ [v] coming between a root-final vowel /ā/ and the masculine singular and plural agreement suffixes, $/-\mathrm{\jmath} /$ and $/-\overline{\mathrm{a}} /$ (feminine forms of these examples do not exist).

(31) $/ \mathrm{w} /$ epenthesis for vowel sequence $/ \overline{\mathrm{a}} /+/ \mathrm{o} /, / \overline{\mathrm{a}} /$

\begin{tabular}{|c|c|c|c|c|}
\hline root & \multicolumn{2}{|c|}{ masculine singular $(+/-\mathrm{\jmath} /)$} & \multicolumn{2}{|c|}{ masculine plural $(+/-\overline{\mathrm{a}} /)$} \\
\hline /nā-/ & /nāws/ & 'spout' & /nāwā/ & 'spouts' \\
\hline /dà-/ & /dà̀wo/ & 'claim’ & /dà̀wā/ & 'claims' \\
\hline /kalā-/ & /kalāwo/ & 'arm clutch' & /kalāwā/ & 'arm clu \\
\hline
\end{tabular}

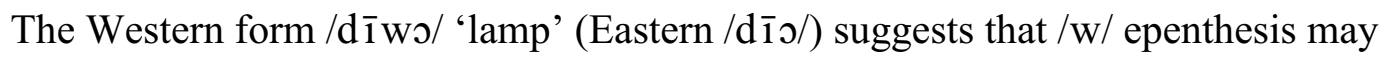
occur in Western between $/ \overline{1} /$ and these agreement suffixes. Unfortunately I have no other examples or counterexamples. All remaining cases of hiatus involve suffixation, and are resolved by either epenthesis or stem vowel modification as explained in 2.4 .

2.4 Morphophonemic Vowel Changes

2.4.1 Vowel Changes with Verbal Suffixation

Significant morphophonemic processes operate when verb stems that end in a vowel are inflected by vowel suffixes, as is evident from the verb paradigms presented in 
Appendix C. All such processes issue from phonotactic constraints, including the need to resolve hiatus of a disallowed vowel sequence.

\subsubsection{Vowel Changes with the Causative Suffix /-āa}

The addition of the causative suffix /- $\overline{\mathrm{a}} / \mathrm{can}$ result in reduction of the root vowel in roots which end in a consonant. An example is /jāg/ 'wake up!',/jagāa/ 'wake [someone] up!' This particular reduction process rarely applies, because there are few long-vowel roots that take the causative suffix.

In roots ending in a vowel, addition of the causative suffix $/-\bar{a} /$ (or /-āl $/$ ) can result in the resolution of hiatus via labialization, and deletion of the original stem vowel. Some common examples are shown in (32).

(32) Labialization in causative verbs ending in a vowel

Verb Root Synthesized Causative Stem

/lā/ 'put on [article of clothing]!' /lwā/ 'dress [someone]!'

/là/ 'remove [article of clothing]!' / /wấ/ 'get [someone] to remove [article of clothing]!'

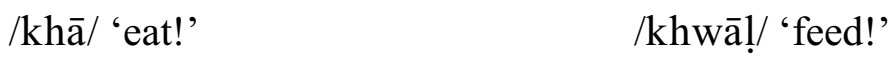

/so/ 'sleep' /swāḷ / 'put to sleep'

The derivation of /lwā/ 'dress [someone]!' from /lā/ 'put on!' shown in (33) - (35)

illustrates this process. First, the inherently stressed causative suffix is added to the underlying verb root:

$$
/ 1 \bar{a}-/+/ \bar{a} /
$$

Next, as the sequence $/ \bar{a} /+/ \bar{a} /$ is generally disallowed in Gojri, an epenthetic $/ \mathrm{w} /$ is inserted between the suffix and the root vowel:

$$
1 \bar{a}+w+\bar{a}>1 \bar{a}^{\prime} w a \bar{a}
$$


Finally, the original stem vowel - now unstressed due to the shift of stress to the syllable containing the causative suffix - is deleted, resulting in the synthesized form: $\operatorname{lă}^{1} w \bar{a}>1 w \bar{a}$

\subsubsection{Vowel Changes with Vocalic Tense, Aspect, and Agreement Suffixes}

The perfective suffix /-e/ $(/-\overline{1} /)$ and a following feminine agreement marker $(/-\overline{1} /$ or $/-\overline{1} \sim /$, the latter is Eastern only) always coalesce to $/-\overline{1} /$.

Verb stems may end in the long vowels $/ \mathrm{o} /, / \overline{\mathbf{a}} /, / \mathrm{e} /, / \overline{\mathbf{1}} /$, and $/ \varepsilon /$. Stems ending in $/ \overline{\mathbf{1}} /$ show no variation other than the absorption of any immediately following suffixed $/ \overline{1} /$. The feminine singular perfective /p $\overline{1} /$ '[he] drank [it [fem.]]' is thus the product of /p $\overline{1}-/$ 'drink', the perfective suffix $/-\overline{\mathrm{e}} /(/-\overline{1} /)$, and the feminine singular suffix $/-\overline{1} /$.

Stems ending in /e/ like 'give' and 'take' raise to $/ \overline{\mathbf{1}} /$ before the first singular suffix $/ \overline{\mathrm{u}} \sim /$.

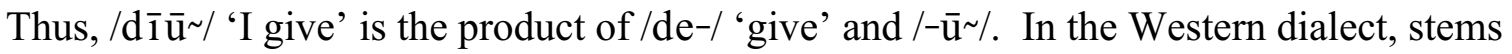
ending in $/ \mathrm{e} /$ will also raise to $/ \overline{\mathbf{1}} /$ before any suffixed $/ \overline{\mathrm{a}} /, / \mathrm{\jmath} /$, or $/ \varepsilon /$. In the Eastern dialect,

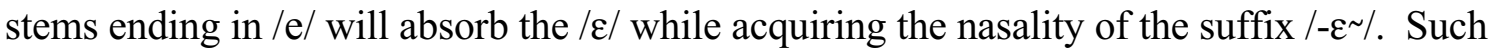
stems also reduce from $/ \mathrm{e} /$ to $/ \mathrm{a} /$ before any suffixed $/ \overline{\mathbf{1}} /$.

Stems ending in /o/ absorb any suffixed / $/$ / in the Western dialect. The Eastern dialect inserts an epenthetic /w/ between the verb /hò-/ 'to be' and any suffixed /ā/, / $/$ / or /o/, but does not do this for other stems ending in $/ \mathrm{o} /$.

For stems ending in $/ \overline{\mathrm{a}} / \mathrm{such}$ as $/ \overline{\mathrm{a}}-/$ 'come', the Eastern dialect inserts an epenthetic $/ \mathrm{w} /$ between the stem vowel $/ \overline{\mathrm{a}} /$ and any suffixed $/ \overline{\mathrm{a}} /, / \varepsilon /$, or $/ \mathrm{\jmath} /$. This epenthetic $/ \mathrm{w} /$ is in free variation with the absence of epenthetic/w/ in the speech of some Western speakers. When the 'vector' verb and passive formative / jā-/ 'go' is immediately followed by the 
future auxiliary $/ \mathrm{k}-/(/ \mathrm{g}-/)$, the two roots will contract without any epenthetic $/ \mathrm{w} /$ such that any suffixed $/ \varepsilon /$ raises to $/ \overline{\mathbf{1}} /$. In the Western dialect, this contraction applies to any verb ending in $/ \overline{\mathrm{a}} /$, although it alternates with the epenthesis process in the speech of some persons. For example, the Western contraction /ā̄ go/ 'he will come' may alternate with the uncontracted and epenthesized /āwe go/.

For stems ending in $/ \mathcal{E} /$ like the defective modal verb $/ \mathrm{p}^{-} /$' fall', the stem vowel changes to /o/ before any suffixed /E/ in the Eastern dialect, but coalesces with the suffixed $/ \varepsilon /$ in the Western dialect. For masculine perfective forms, the stem vowel $/ \varepsilon /$ is absorbed by the perfective suffix /-e/ $(/-\overline{1} /)$, whereas for feminine forms it is reduced to /a/ before the perfective suffix.

Stems ending in the high-tone $/ \hat{\varepsilon} /$ are particularly subject to morphophonemic change. For verbs such as / $\mathrm{k} \varepsilon$ / 'say' and /rél 'stay', the stem vowel remains unchanged before a vowel suffix only when coalescing with another suffixed $/ \varepsilon /$, and before the future imperative suffix $/-\overline{\mathbf{1}} \sim /$ in the Western dialect. In both dialects it reduces to $/ a ́$ / before $/ \overline{\mathbf{u}} /$ and before all remaining cases of suffixed $/ \overline{1} /$. Before a suffixed $/ \mathrm{\partial} /$ it raises to $/ \mathrm{e} / \mathrm{in}$ Eastern and to $/ \overline{1} /$ in Western. In all cases the resulting suffix carries the high tone from the original stem vowel. The inflections of /ré/ 'stay' given in Table 4 below attest these changes.

For verb stems ending in vowels, irregular suppletive forms abound - especially in the irregular perfectives, as is evident in Appendix C (see also 4.2.1.1.3 on the old -ita participle in Gojri). 
Table 4. Morphophonemic Changes for Stems Ending in /ع́/: /ré/ 'stay' (unique Western forms are in parentheses)

\begin{tabular}{|c|c|c|c|c|c|}
\hline & & Stem & (Tense) & Agreement & Full form \\
\hline \multirow[t]{5}{*}{ Unspecified } & $1 \mathrm{sg}$. & ré- & & $-\overline{\mathrm{u}} \sim$ & ráū $\sim$ \\
\hline & $1 \mathrm{pl}$. & ré- & & $-\overline{\mathbf{a}} \sim$ & ráa \\
\hline & $2 / 3 \mathrm{sg}$ & ré- & & $-\varepsilon$ & ré \\
\hline & $2 \mathrm{pl}$ & ré- & & $-0(-\varepsilon)$ & ró (ré) \\
\hline & $3 \mathrm{pl}$ & ré- & & $-\varepsilon^{\sim}(-\varepsilon)$ & ré (ré) \\
\hline \multirow[t]{2}{*}{ Present Imperative } & 2 sg. & ró- & & $\emptyset$ & ró \\
\hline & $2 \mathrm{pl}$ & ré- & & $-0\left(-0^{\sim}\right)$ & ró (ró ) \\
\hline \multirow[t]{3}{*}{ Future Imperative } & $2 \mathrm{sg}$ & ré- & $-\overline{1}(-\overline{1} \sim)$ & $-\mathrm{e}$ & rá1e (ré̄i $\sim \mathrm{e})$ \\
\hline & $2 \mathrm{pl}$ & ré- & $-\overline{1}(-\overline{1} \sim)$ & $-0\left(-\jmath^{\sim}\right)$ & 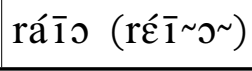 \\
\hline & & Stem & Aspect & Agreement & Full form \\
\hline \multirow[t]{4}{*}{ Perfective } & m.sg. & ré- & -e $(-\overline{1})$ & -0 & réo (rín) \\
\hline & m.pl. & ré- & -e $(-\overline{1})$ & $-\overline{\mathrm{a}}$ & réā (róña) \\
\hline & f.sg. & ré- & -e $(-\overline{1})$ & $-\overline{1}$ & rá 1 \\
\hline & f.pl. & ré- & -e $(-\overline{1})$ & $-\overline{1} \sim(-\overline{1})$ & ráīi (ráī) \\
\hline
\end{tabular}

\subsubsection{Vowel Changes with Nominal Suffixation}

Nominal and adjectival roots ending in /o/ [o: ] reduce to $/ \mathrm{u} /[\mathrm{U}]$ in the speech of some Gujars when suffixed by the masculine agreement markers $/-\mathrm{\jmath} /$ and $/-\overline{\mathrm{a}} /$. The phenomenon seems to be a matter of idiolect rather than dialect, as persons from the same household often differ with respect to it. Some examples are given in (36).

(36) Reduction of nominal root vowel /o/ [o: $]$ to /u/ [u]

root reduced masc. variant unreduced variant feminine singular (or diminuitive)

\begin{tabular}{|c|c|c|c|}
\hline /to-l 'roti pan' & [tuo: $]$ & [to:o: ] & [to:i:] E. only \\
\hline /go-/ 'manure' & [guo: & [go:0:] & [go:i:] \\
\hline
\end{tabular}




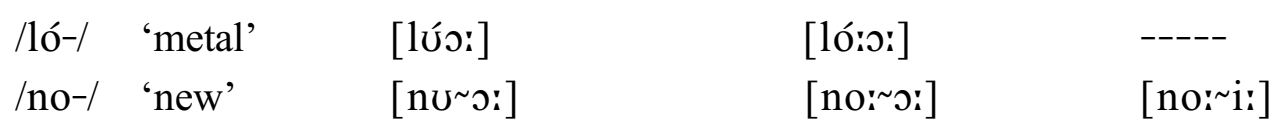

Another idiolectic feature occurring with nominal suffixation is the use of an epenthetic glide between the oblique plural marker $/-\overline{\mathrm{a}} \sim /$ and monosyllabic noun stems ending in the vowels $/ \overline{\mathrm{a}} \sim /$ and $/ \overline{\mathrm{a}} /$. This epenthesis is in free variation with the absence of epenthesis, in which case the oblique plural marker simply coalesces with these nominal stem vowels (the resulting words are phonetically longer than their uninflected forms). Some examples from Eastern speech are provided in (37). Such forms are typical of my Eastern associate, but not of his mother and older brother.

(37) Epenthesis with inflected nouns ending in a vowel (only Eastern forms shown)

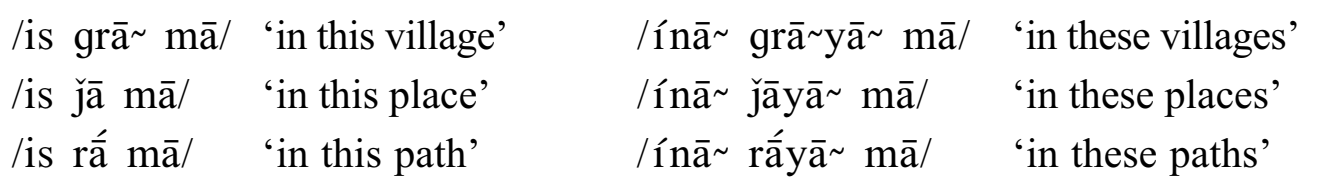
The same kind of epenthesis occurs in Western speech, although with the geminated /yy/ glide, as in /gā $\mathrm{yy}^{\mathrm{a}} \sim$ (ko dúd)/ 'cows' (milk).' This form is typical of the speech of my Western associate's mother, whereas my Western associate simply says /gā (ko dúd)/ 'cow(s) (milk)' which is formally ambiguous in number. Such epenthesis is not noted for polysyllabic stems, e.g. Eastern /(únā ) pèṇ̄a $\sim$ (nā)/ ‘(to those) women' vs. /(us) pèṇā (nā)/ '(to that) woman.' At least one instance of (presumably) obligatory epenthesis occurs in an idiom common to both dialects: /mā yā bāpā ko ke hàl hè/ 'How are [your] parents?' (Eastern). Here epenthesis occurs between the first word, /mā / 'mother', and the oblique plural marker /-āa/, creating /mā $\sim \bar{a} \sim /$ in Eastern speech and /mā $\sim y y \bar{a} \sim /$ in Western. 


\subsection{Other Processes}

\subsubsection{Assimilation of $/ 1 /$ and $/ 1 /$}

The retroflex /1/ becomes dental /1/ in clusters before any dental area consonant. For example, phonemic /baḷto ré/ 'keeps burning' becomes phonetic [balto ré] after the /1̣/ of the root assimiliates to the point of articulation for the imperfective suffix /-t/. Similarly, dental /l/ becomes retroflexed before a retroflex consonant as in /bālṭ̂ $/$ [baḷṭ̂] 'bucket.' This process is not noted for consonants other than $/ 1 /$ and /1/.

\subsubsection{Assimiliation of the Dative Postposition $/ \mathrm{na} /$ to the Infinitive}

When the dative postposition /nā/ inflects an infinitive in a purpose clause in normal speech, the postposition and infinitive contract such that the initial /n/ assimilates to the retroflex point of articulation of the infinitive suffix /ṇ/. For example, phonemic /māruṇ nā/ 'for hitting' becomes phonetic [māruṇn̄ā] in pronunciation.

\subsubsection{Avoidance of Cluster $/ \mathrm{mn} /$ by Replacement of $/ \mathrm{n} /$}

Eastern Gojri disallows the cluster $/ \mathrm{mn} /$, such that the co-location of $/ \mathrm{m} / \mathrm{and} / \mathrm{n} /$ at morpheme boundaries is resolved via replacement of /n/ with /ṇ/. This process is most readily observable in the first and second plural dative and agentive pronominal forms. The following replacements/contractions are obligatory when first and second plural pronouns are followed by the postpositions /nā/ (dative case) and /ne/ (agentive case) without any intervening words:

(38) Cluster $/ \mathrm{mn} /$ avoidance via replacement of $/ \mathrm{n} / \mathrm{with} / \mathrm{n} /$ in Eastern pronominal forms

/hàm ne/ [hìmṇe: ] 'we did' /hàm nā/ [hìmṇa: ] 'to us' vs. [hìm lo:ka: ne: ] 'we people did'

vs. [hìm lo:ka: na: ] 'to us people' 
/tam ne/ [tımṇe: ] 'you did' vs. [tım lo:ka: ne: ] 'you people did'

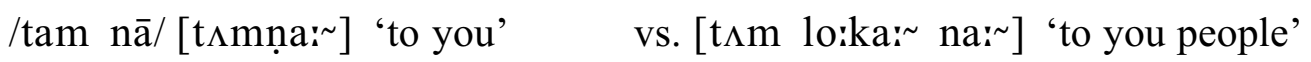

2.5.4 Replacement of the Infinitive Suffix /-n / with /-n/

When the infinitive suffix /-ñ is affixed to verb stems ending in a retroflex sonorant, articulatory difficulty is resolved through the replacement of /ñ with /n/. Some examples and counterexamples are shown in (39).

(39) Replacement of infinitive suffix /-n/ with /n/ following retroflex sonorants
/āṇṇı/ [a:ṇəno] 'to bring'
/bāṛ̣ı/ [ba:ṛono] 'to bring inside'
/pāḷno/ [pa:ḷıno] 'to tend (animals or children)'
/káḍno/ [kúḍ̀no/ 'to remove'
/uṭhṇo/ [uṭhə̣̣o] 'to rise' (no replacement following non-sonorant)
/miṭ̣o/ [miṭıṇo] 'to fit' (no replacement following non-sonorant)

\subsubsection{Voicing Assimilation of the Genitive Postposition /k-/}

In the speech of many Western dialect speakers, the genitive postposition $/ \mathrm{k}-/$ becomes $\left[\mathrm{g}^{-}\right]$following any nasalized vowel or nasal consonant. Compare the examples in (40).

(40) Voicing of genitive postposition $/ \mathrm{k}-/$

$\begin{array}{ll}\text { /ún kā (ḍerā)/ [ûn ga: (ḍe:ra:)] } & \text { 'their (houses)' } \\ \text { /ún lokā̃ kā (ḍerā)/ [ûn lo:ka: ga: (ḍe:ra:)] } & \text { 'those people’s (houses)' } \\ \text { /us ko (ḍero)/ [us ko: (ḍe:ro:)] } & \text { 'his (house)' }\end{array}$

\subsubsection{Perseveratory Nasalization}

All oral vowels become nasalized when immediately following a nasal consonant. As in other languages, the degree of phonetic nasalization in Gojri is directly related to vowel 
height and length, with lower long vowels becoming the most nasalized (due to lowering of the velum during production of low vowels). For example, the effect is profound for $/ \overline{\mathbf{a}} /$ and negligible for $/ \mathbf{i} /$. Other than $/ \overline{\mathbf{a}} /$, the nasality of long vowels so nasalized is less than that of corresponding phonemic nasal vowels. Thus, the locative and dative postpositions, /mā/ and /nā/, respectively, are phonetically identical to /mā $\sim$ ' mother' and /nā $/$ 'name', the nasalized vowels of which are both underlying. Such nasality does not 'persevere' into a second vowel, nor does that of the so-called 'nasal clusters' extend through the non-nasal consonant to a following vowel. Some other words which attest this process and its scope are shown in (41).

(41) Nasalization of vowels following nasal consonants

nasalization realized on a final vowel due nasalization not realized on a final vowel due to immediately preceding nasal consonant to segment intervening after the nasal

\begin{tabular}{|c|c|c|}
\hline 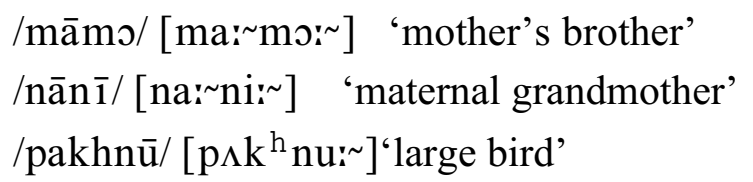 & $\begin{array}{l}\text { /noo/ [no: o: }] \\
\text { /mūo (wo)/[mu: o: (vo:)] } \\
\text { /kanḍo/ [kıṇḍo: }]\end{array}$ & $\begin{array}{l}\text { masc. } \\
\text { masc. }\end{array}$ \\
\hline pāṇ̄îl/ [pa:ṇi: ] 'water' & /angār/ [ $\Lambda$ yga:r $]$ & \\
\hline
\end{tabular}

2.6 Representation of Gojri Phonemes in the Gojri Script

\subsubsection{Representation of Consonant Phonemes}

With the exception of the unique retroflexes /ñ and /l//, Gojri consonant phonemes may be readily represented as per the representation of the equivalent consonants in Urdu. Geminated consonants should be marked as Urdu geminates are marked; i.e. with the superscript diacritic, tashdeed (or shad, /šad/). In the case of the phonemes /t/, /h/, $/ \mathrm{s} /, \mid \mathrm{z} /$, and $/ \mathrm{k} /$, one or more additional graphemes from the Perso-Arabic inventory is 
required to preserve the original spellings of the loan words in which they occur (this convention applies in Urdu as well). Original pronunciations are seldom applicable, although educated speakers may read [q] rather than the usual (Gojri-ized) [k] in words bearing the letter ق (e.g. many names including [qura:n] 'Qur'an').

Masica notes that attempts to remove the redundant loan-word graphemes in the writing of other Indo-Aryan languages have generally failed to catch on, given the religious significance of the Arabic language (1991:151). Their removal from Gojri would constitute a significant obstacle to successful transitional literacy by requiring the reader to learn multiple spellings of the same words: original spellings for Urdu texts and onephoneme-one-grapheme spellings for Gojri texts (per the approach recommended by Sharma 1979:148-149). In practice, Gujar writers almost always use the original spellings.

\subsubsection{Representation of the Gojri Retroflexes / $\mathbf{n} /$ and $/ \mathrm{l} /$}

A variety of techniques has been used for representing the Gojri retroflexes /ṇ/ and /ḷ/. Some writers, whether for lack of an alternative or due to an incorrect belief that these segments are merely allophones of /n/ and /1/, simply write them as /n/ and /1/ (ن J J J respectively). This approach, by ignoring the phonemic status of these segments, introduces a measure of ambiguity that is potentially detrimental to new readers. It also deprives written Gojri of its best opportunity for a distinctive appearance, something that many Gujars desire. Recognizing a real need to differentiate retroflex /ṇ/ and / $1 /$ from their dental counterparts (and that the retroflex-marking diacritic $b$, or toe, was ineligible 
due to certain confusion between the writing of /ț/ and / $1 /$ in medial contexts), Sabir Afaqi in 1976 proposed unique graphemes in the introduction to his Phul Kheli, a book of Gojri

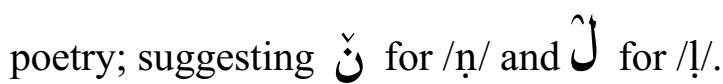

These representations have since been utilized by Professor Afaqi and several of his associates in Pakistan and Pakistan-administered Kashmir. While the former has also become the convention of choice on the eastern side, the latter has been rejected there in

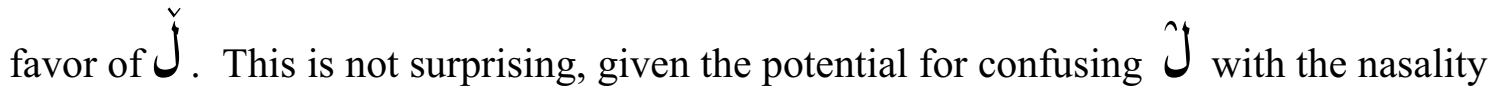
grapheme $\hat{\mathcal{U}}$ (nun gunno). Professor Afaqi says that he avoided the possibility of $\mathfrak{J}_{\text {due }}$ to concern that it would be confused with $\check{ن}$ if the latter's center nuqtah ('dot') was inadvertantly omitted (2002: personal communication).

It is questionable, however whether an orthographic convention ought to be decided by considerations of error, especially considering how many pairs of letters in Urdu and English are distinguished by a single graphic feature. There is also the fact that most of the Gojri text that Gujars will read in the future will likely be published with the aid of computers (which generally preclude intra-graphemic errors).

The use of $\check{U}$ and $\breve{J}$ for /ṇ/ and /l!/, respectively, has the following advantages: (1) it differentiates these segments from their dental counterparts, but by a single and consistent feature, namely, the inverted wedge, or /puṭho aṭ/ as it is called in Gojri; (2) on account of its promotion by the Jammu \& Kashmir Academy of Art, Culture \& 
Languages it enjoys greater current acceptance than any other alternative (albeit mainly in Indian-administered Kashmir); (3) it enables readers to tell by a simple glance that a page of text is Gojri rather than Urdu (or some other regional language); and (4) the inverted wedge character is supported by the widely available InPage 2000 desktop publishing software for the Perso-Arabic script type (perhaps owing to the use of this convention in some Punjabi writing). I believe, therefore, that these graphemes represent the best opportunity for Gujars to standardize the representation of $/ \mathfrak{n} /$ and $/ 1 /$. The adoption of

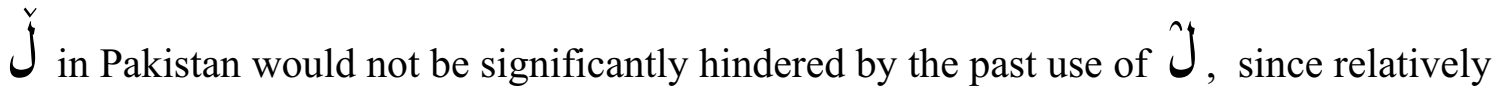
few Pakistani Gujars have ever seen their language in print. The adoption of any new representations by Gujars in the eastern area would seem considerably more complicated.

For sake of completeness we should note that the graphemes for $/ \mathrm{n} /$ and $/ \mathrm{l} /$ designed and forwarded by Sharma $(1979: 150,163,167)$ are not to my knowledge in use by Gujar writers in any quarter and for that reason do not warrant consideration at the present time.

\subsubsection{Representation of the Geminated Retroflex Lateral /1!/}

Sabir Afaqi has designed and proposed a special grapheme to represent the geminated retroflex lateral /1! / (1976). Since this character is not supported by any word processing software, the segment might be written more simply by using the retroflex lam marked with the tashdeed or shad diacritic to show the gemination; i.e. J J This would also avoid the introduction of a new alphabet letter, potentially simplifying the literacy task. Writers from the other Pakistani Gojri dialects can readily represent the cognate cluster 


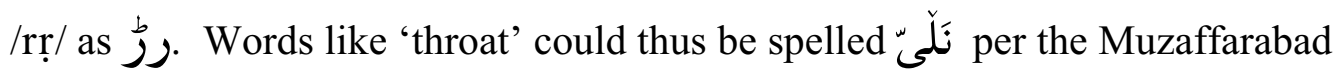
pronunciation /nall11/, and alternately as نَرُّى per the Kaghani and Allaiwal pronunciation $\operatorname{lnarri} \overline{1} /$.

\subsubsection{Representation of the Glides /w/ and /y/}

Fortunately, none of the allophonic variation for $/ \mathrm{w} /$ noted above (in 2.1.3.3) presents a serious orthographic challenge, since the Perso-Arabic $g, v a w$, does duty for phonetic $[\mathrm{v}],[\mathrm{w}]$, and [o]. Epenthetic /w/ can be written with vaw before the second plural suffix /-o/, also written with vaw, even though it only occurs in some Eastern varieties: ، بوووكا /hòws kā/ 'you pl. will be.' Readers lacking this epenthetic /w/ in their own speech can read the first vaw as /o/ right along with the second vaw, and at worst the /o/ is read as longer than it is actually pronounced. This solution should be tested against one omitting the epenthetic vaw with readers from a variety of pronunciation types. The contrastive variation of initial /w/ (Eastern) and /b/ (Western) cannot be neutralized by the script, and can only be written according to the author's pronunciation.

Both the palatal glide /y/ and all occurrences of the vowel /e/ are represented by various allographs of the letter ye in the Perso-Arabic script. Medially, /yy/ can be distinguished from /y/ (=/e/) by means of the superscript diacritic, hamza (Gojri /hàmzo/), which indicates the juncture of two vowels, but when written above medial ye can also be understood to indicate a higher point of articulation than the absence of 
hamza. In final position, /e/ is written with bari ye, $\_$. Final/y/, approximating in

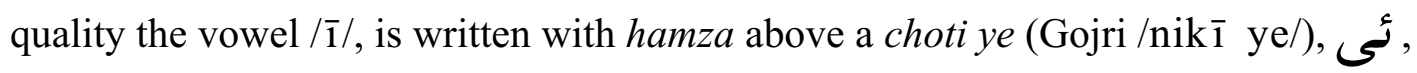
whereas final vocalic $/ \overline{1} /$ is written without any hamza owing to the absence of any preceding vowel. Some sample spellings are shown in Table 5.

Table 5. Orthographic Differentiation of Medial /y/ and/yy/, Final /y/ and /e/

$$
\text { initial and final /y/, medial /yy/ medial /y/ and final /e/ }
$$

\begin{tabular}{|c|c|c|c|c|}
\hline initial & 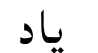 & 'memory' & --- & ------ \\
\hline \multirow[t]{2}{*}{ medial } & يائيو & /pāyys/ 'grazing fee' & يايو & /pāys/ ‘[bed] leg' \\
\hline & آئيو & $/ \bar{a} \overline{1}\lrcorner /(/ \bar{a} \overline{1} \sim \rho /)$ fut. 'you pl. come!' & آيو & /āys/'he came' \\
\hline final & ائى & /pà̀y/ (/bà̀y/) 'brother’ & كان & /kāe/'someone, \\
\hline
\end{tabular}

\subsubsection{Representation of Nasalized Vowels and Nasal Clusters}

In the writing of nasal clusters, the nasal phoneme is represented by a constant $/ \mathrm{n} / \mathrm{in}$ a phonemic orientalist transcription, and by a constant nun gunno /nun yunno/, $\mathcal{u}$ or $\hat{\mathcal{U}}$, in the script, regardless of actual phonetic shape. Nasalized vowels are written with a nun gunno after the oral vowel, and all nasal clusters are thus represented as nasalized vowels followed by a consonant. This linguistically sound convention is followed in Gojri as in Urdu. Representing this segment by $/ \mathrm{n} /$ in the script, that is by $\dot{\mathcal{u}}$ or $n u n$, is contrary to regional orthographic conventions in which $/ \mathrm{n} /$ is rejected even when the 
following consonant is alveolar, e.g. the word for 'ox' is spelled in script as /dā $\sim d /$ 'ox' rather than /dānd/. Similarly, if the following consonant is retroflex and the nasality is realized as phonetic [n] , a spelling that uses the Gojri character for /ṇ/ is rejected outright. Exceptions include words that have a historic /n/, such as /sūnt $\overline{1} /$ 'circumcision' from /sunat/ 'apostolic precedent', /dukāndār/ 'shop keeper' from /dukān/ 'shop', and /minț/ [mınț] from the English 'minute.' For all such words nun, rather than nun gunno, is mandatory in the spelling.

\subsubsection{Phoneme/Grapheme Associations for Gojri Consonants}

The complete inventory of Gojri consonant graphemes is presented in Table 6. Only the independent or un-joined form of each grapheme is shown. Aspirated consonants consist of digraphs, the second grapheme being the aspirate $\$$, or do chasmi he. For phonemes associated with multiple monographs, the 'redundant' Arabic letters are shown to the right of the indigenous letter in order of decreasing frequency.

Table 6. Phoneme/Grapheme Associations for Gojri Consonants

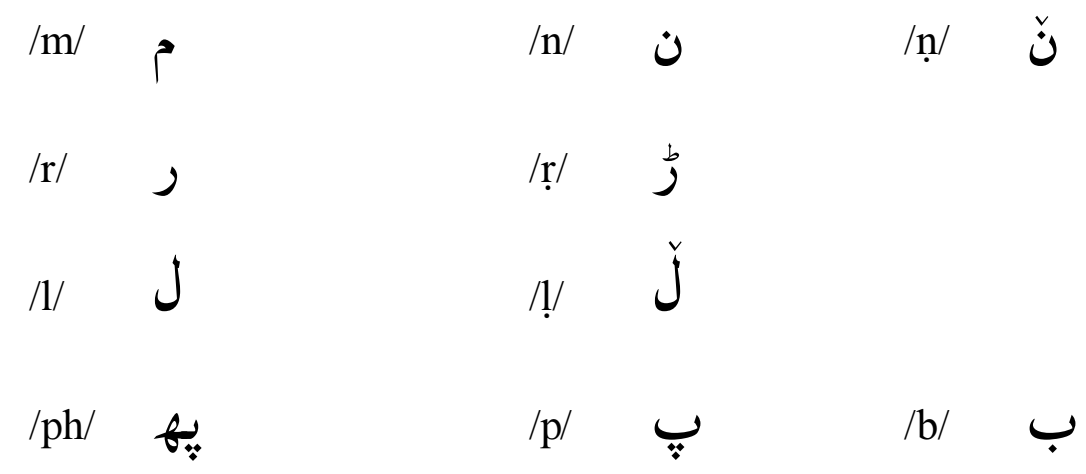


Table 6 cont.

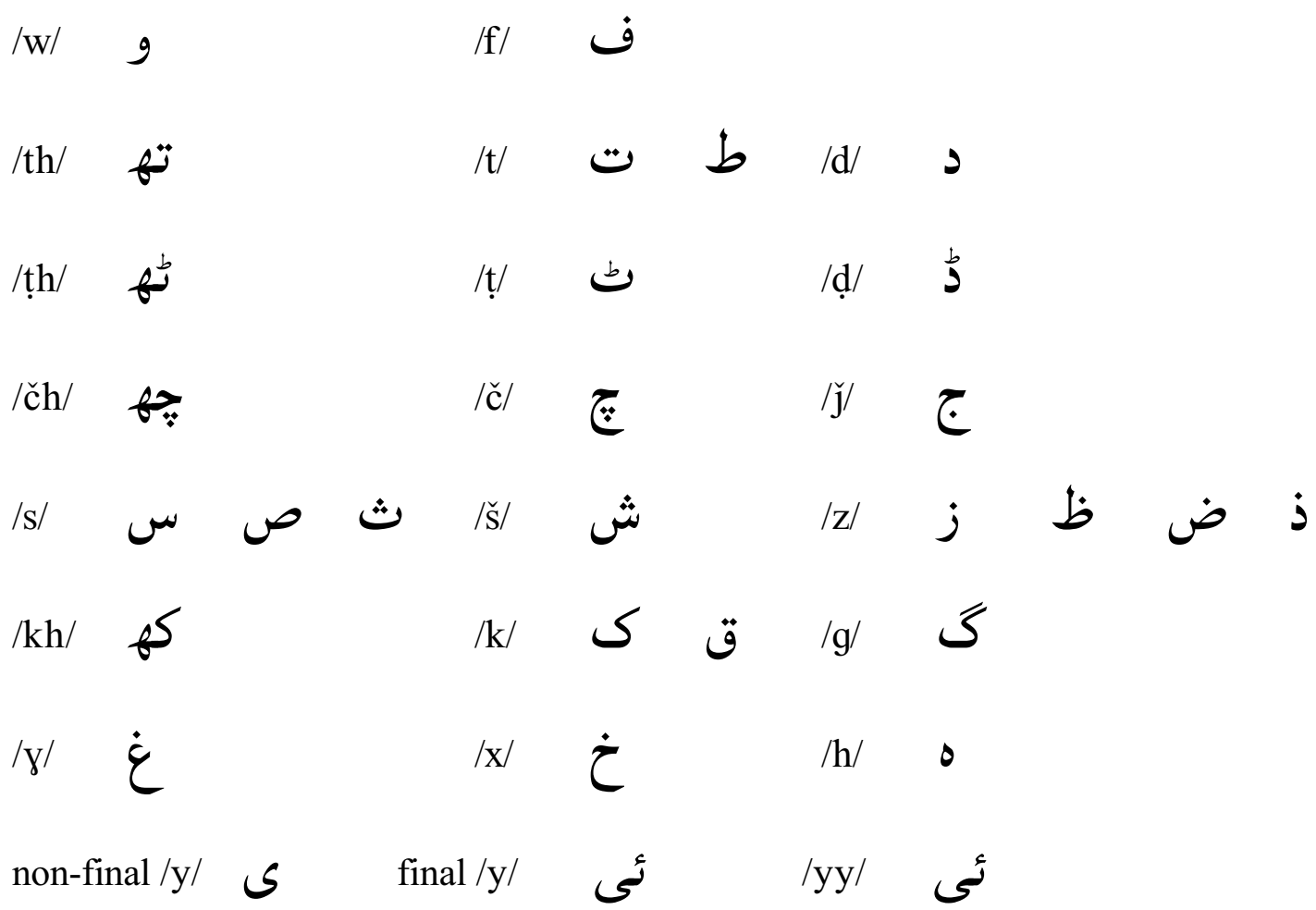

\subsubsection{Representation of Vowel Phonemes}

Since the ten vowel phonemes correspond to those for Urdu, there is every reason to write them as they are written in Urdu. Although the Perso-Arabic script is notoriously ill-suited for the vowel distinctions made in Indo-Aryan languages (Masica 1991:151), this under-representation may actually work to the advantage of Gojri standardization since many words that have different vowels cross-dialectically can be written in a uniform fashion if the diacritics are omitted. For example, minus the diacritics, Eastern /sanés/ 'message' and its Western counterpart/sin⿳亠丷厂 $/$ can both be written as a constant سنيمو rather than separately as سِنِيهو respectively. 
The independent forms of the vowel graphemes for Urdu and Gojri are summarized in Table 7. The reader is referred to instructional Urdu materials for futher detail about the writing of vowels (e.g. Mathews 1999:ix-xxxii).

Table 7. Phoneme/Grapheme Associations for Gojri Vowels

\begin{tabular}{|c|c|c|}
\hline$/ \mathrm{a} /$ & 1 & $/ \overline{\mathbf{a}} /$ \\
\hline /i/ & 1 & $/ \overline{\mathbf{1}} /$ \\
\hline $\mid \varepsilon /$ & & $/ \overline{\mathrm{e}} /$ \\
\hline$/ \mathrm{u} /$ & | & $/ \overline{\mathrm{u}} /$ \\
\hline & آو & $/ \overline{\mathbf{o}} /$ \\
\hline
\end{tabular}




\section{CHAPTER III}

\section{GOJRI TONE AND ITS REPRESENTATION}

The representation of tonal phenomena constitutes a significant challenge to Gojri orthography standardization. The complications issue naturally from the lack of tonal phenomena in the languages historically accommodated by the Perso-Arabic script, especially Urdu, the language of wider communication for most Gujars. Motivating an Urdu-based solution to this challenge is the fact that literate Gujars are literate in Urdu, a fact which has obvious implications for literature development and transitional literacy programming. Making such a solution at least potentially feasible is the regular, albeit incomplete correspondence of Gojri tonal phenomena to Urdu aspiration phenomena.

A complete analysis of Gojri prosody is a study I have not yet undertaken. My purpose here is to present a preliminary analysis of Gojri lexical tone, and then explore a consistent orthographic representation of Gojri tone in an Urdu milieu. At points the data is organized with reference to Urdu correspondences, as these correspondences are weighted heavily in the evaluation of orthographic solutions.

\subsection{Gojri Tonal Phenomena}

\subsubsection{Phonetic Pitch Contrasts}

Sharma describes a three-way tone or pitch contrast for Punch Gojri (1979:110-113; 1982:12). This observation also holds for Kaghani and Allaiwal Gojri. Phonetically, the contrasting pitches consist of a level high pitch (level tone or 'mid tone'1 ) which is not marked in transcription, a high-falling pitch contour (or 'high tone') marked with (' ) 
above the vowel in my phonemic transcription, and a low-rising pitch contour (or 'low tone' ) marked with (' ) above the vowel. The high-falling contour commences at an extra-high pitch relative to that of the level high pitch and glides to a mid pitch that is lower relative to that of the level high pitch. When another syllable follows the stressed syllable within the word, the stressed syllable will have the extra-high pitch and the larger part of the fall to the mid pitch occurs on the following syllable. In phonetic transcriptions, this is indicated by writing [' $\left.{ }^{\prime}\right]$ on the stressed syllable and ['] on the following syllable, whereas a glide fully executed on the stressed syllable is indicated by [ ${ }^{\wedge}$ ]. The low-rising contour commences at an extra-low pitch relative to that of the level high pitch and glides to a mid pitch that is lower than the level high pitch. When another syllable follows the stressed syllable within the word, the stressed syllable will have the extra-low pitch and the larger part of the rise to a mid pitch occurs on the following syllable. In phonetic transcriptions, this is indicated by ['] on the stressed syllable and $\left[^{\prime}\right]$ on the following syllable, whereas a glide fully executed on the stressed syllable is indicated by [ $\left.{ }^{\vee}\right]$.

Concomitant with the initial extra-low pitch of the low-rising contour is creaky voice, in which the vocal cords are more tense than in normal voicing and therefore produce a creaking sound. In many words of the Eastern dialect, the low-rising contour follows a voiceless initial plosive (as is also the case in Punjabi, see Masica 1991:205). This voiceless plosive corresponds to a voiced plosive at the same point of articulation in the Western dialect, and to a breathy-voiced plosive at the same point of articulation in Urdu cognates. For example, the word 'horse' is /'kòṛ/ in Eastern, /'gòṛ/ in Western, /'kòrāâ/ in Punjabi, and /'ghorāâ/ in Urdu. For some words of this type, a level low pitch, higher 
than the 'extra-low' pitch of the low-rising contour but still marked [' ] phonetically, occurs with creaky voice on any syllables preceding a low-rising contour. Both contour tones are extremely common, and there do not seem to be any general constraints on the kinds of consonants, vowels, or syllable patterns with which either may occur. In words with level high pitch, there is no conspicuous pitch rise or pitch fall; however, the pitch of the stressed syllable is somewhat higher than the mid pitch of the other, unstressed syllables, but lower than the 'extra-high' pitch of the high-falling contour.

Thus, there are at least five phonetic pitches in Gojri: 'extra-low', the initial pitch of the low-rising contour; 'low', the pitch occurring with creaky voice prior to the low-rising contour in some low-tone words; 'high', the pitch of stressed syllables in level-tone words; 'extra-high', the initial pitch of the high-falling contour; and 'mid', the pitch on which both of the gliding pitches terminate, and the pitch of unstressed syllables in leveltone words and of unstressed syllables preceding non-initial low-rising contours. Careful acoustic analysis may ultimately show that there are multiple non-contrastive phonetic pitches within what I am now calling 'mid' pitch.

Contrasts between the three phonetic pitch melodies serve to differentiate lexical items such as those in (42), but do not function morphosyntactically.

(42) Contrasts of high-falling, level, and low-rising pitch melodies

$$
\begin{aligned}
& \text { /'sấro/ ['sá:rò] （phonetic high-falling pitch) masc. 'flat' } \\
& \text { /'sāro/ ['sa:ro] (phonetic level high pitch) masc. 'entire' } \\
& \text { /'sà̀ro/ ['sà:ró] （phonetic low-rising pitch) 'assistance' } \\
& \text { /là́/ [lâ: ] (phonetic high-falling pitch) 'take off [article of clothing]!' } \\
& \text { /lā/ [la: ] (phonetic level high pitch) 'put on [article of clothing]!' } \\
& \text { /làl/ (/hì'lāl/) [lǎ:l] (phonetic low-rising pitch) 'slay!' }
\end{aligned}
$$




\begin{tabular}{|c|c|c|}
\hline /čáṛ̂ [čârụ] & (phonetic high-falling pitch) & 'climb!' \\
\hline /čar / [čar $]$ & (phonetic level high pitch) & 'bed bug' \\
\hline /čàṛ̣/ (/jà̀r $/)$ [čăṛ̣] & (phonetic low-rising pitch) & 'fall!' also 'cloud' \\
\hline$[\mathrm{b} \hat{\varepsilon}: \mathrm{s}]$ & (phonetic high-falling pitch) & 'argument' \\
\hline [be:s] & (phonetic level high pitch) & sit!' \\
\hline ès / (/b & (phonetic low-rising pitch) & 'apparel' \\
\hline
\end{tabular}

\subsubsection{Analysis of Gojri Tone}

\subsubsection{Tone and the Stressed Syllable}

Lexical pitch is associated with the stressed syllable in Gojri words (meaning Gojri is more like Swedish than Mandarin or other truly tonal languages where every syllable is tonally marked). The level tone occurs only on the stressed syllable. In monosyllabic words, contour tones are realized within a single syllable, which in the absence of any other syllable receives stress by default. In polysyllabic words, the contour tones typically commence at their pitch targets on the stressed syllable and conclude at a mid pitch in any following syllable, often a gender-number agreement marker.

Foundational to any discussion of the underlying nature of these phonetic pitch contrasts in Gojri is the topic of lexical stress assignment. The assumption is that, within a morpheme, the location of stress can be predicted by syllable weight. Syllable weight, in turn, is determined by the number of segments, or moras $(\mu)$, in the 'rhyme', where the rhyme of a syllable consists of the vowel nucleus plus any trailing consonants, and where a long vowel counts as two moras. Distinctions can therefore be made between light (where the rhyme consists of V), heavy (where the rhyme consists of VV or VC), and superheavy syllables (where the rhyme consists of VVC or VCC). There have been several studies of stress placement in Hindi-Urdu (e.g. Dyrud 2001, Hussain 1997). If 
the final segment of a word is considered to be extra-metrical (not counted with respect to determination of syllable weight), then stress rules for Hindi-Urdu can be summarized as follows: the last heavy syllable in a word is stressed; if there is no heavy syllable (i.e. if the word consists of light syllables only), the penultimate syllable is stressed.

These same stress assignment rules operate in Gojri. For example, the word / jisam/ ['ǰsəm]'body' is stressed on the first syllable because, once the word-final mora, [m], is excluded, what remains are two equally weighted CV syllables of which the penultimate is stressed (remember that short vowels consist of one mora, V; long vowels consist of two, represented as VV). In the word /as'māṇ/ [ $\Lambda s^{\prime}$ ma:ṇ] 'sky', the second syllable receives the stress by the same assignment process. Segmented into syllables and moras, the word yields |as.maan|. With or without the required exclusion of the final mora [n] , the second syllable is the last heavy syllable and therefore the one to receive stress. In morphologically complex words, morphological rules may supersede the normal stress placement rules. For example, in verb stems formed with the causative suffix, the suffix is always stressed, superseding stress placement based on syllable weight.

Throughout this chapter I have included stress marking in the phonemic representations, despite the predictability of stress, so that the reader will not have to determine the location of stress for each example.

\subsubsection{Composition of Contour Tones}

It is useful to think of the two contour tones as combinations of two level tones, one 'high' and one 'low.' In abstract terms, the high-falling contour is thus a combination of a relatively high pitch, $\mathrm{H}$, and a relatively low pitch, L. Phonetically, an underlying HL combination is realized as an extra-high pitch resolving in a mid pitch on a subsequent 
mora, and an underlying LH combination is realized as an extra-low pitch resolving in a mid pitch on a subsequent mora. I will assume that the presence of any $\mathrm{H}$ in a contour melody is by default, i.e. $\mathrm{H}$ is assigned to all stressed syllables. The presence of any $\mathrm{L}$ in a contour melody is lexical, i.e. it is part of the specification of the phonological form of a word in the lexicon. When a stressed syllable receives an $\mathrm{H}$ by default, and no underlying $\mathrm{L}$ is present in the word, the phonetic result is a level high pitch.

Diachronically, the genesis of this low pitch (L) in the lexicon is related to a word$\operatorname{initial} / \mathrm{h} /$, or to the loss of aspiration, $/ \mathrm{h} /$, or /s/ at an earlier linguistic stage (cf. Masica 1991:119-120). Such evolution is attested even by dialectical variants such as the Eastern /hàk-/ 'be able' and the older, Western (and Urdu) cognate /sak-/ 'be able.' Many of the older word forms are attested by Urdu cognates of Gojri words (cf. Masica's discussion of Punjabi tonogenesis; 1991:205). The location of lexical L in a root corresponds roughly to the location of the earlier segment that has disappeared. What determines whether the L is ultimately realized within a high-falling melody or a low-rising melody is its location with respect to the nucleus of the word's stressed syllable. If it precedes the stressed nucleus, the result is LH (low-rising). If it follows the stressed nucleus, the realization is HL (high-falling).

\subsubsection{Low-Tone Causatives of High-Tone Verbs}

The clearest evidence of the existence of lexical L in Gojri and its participation in falling and rising tones is seen in a number of causative and non-causative pairs of verbs. For many verbal roots, the addition of the suffix $/-\bar{a} /$ yields a new causative verb stem. A classic example that holds for other area languages as well as for Gojri is the root/pak-/ ['p $\left.\mathrm{k}^{-}\right]$'ripen, be cooked' and its causative counterpart, /pa'kā-/ [p $\left.\Lambda^{\prime} \mathrm{ka} \mathrm{:}^{-}\right]$'cook.' Since 
there is no lexical $\mathrm{L}$ associated with the root, only default $\mathrm{H}$ applies. As a result, the high pitch is realized on the stressed syllables of both forms and the mid pitch is realized on the unstressed first syllable of /pa' $\mathrm{ka}-/$ (note the shift of stress to the causative suffix; see 4.2.1.5 for other examples of causative/non-causative verb pairs with constant level pitch melodies). However, when a lexical $\mathrm{L}$ is associated with the latter part of the verb root, its phonetic realization in all inflections of the root will be high-falling. Again, this is because $\mathrm{H}$ is assigned by default to the stressed mono-syllabic root, the nucleus of which precedes lexical L in the vicinity of the coda; thus HL. Whenever the inherently stressed causative suffix is added to make a new stem, the stress shifts from the verb root to the causative suffix such that default $\mathrm{H}$ then follows lexical L; thus LH. Consider the examples in (43).

(43) Non-causative and causative manifestations of lexical low pitch (L)

Verb stem consisting of root Verb stem consisting of root + causative suffix $/ \overline{\bar{a}} /$ (showing high-falling tone) (showing low-rising tone)

\begin{tabular}{|c|c|c|}
\hline /báṇ/ 'become!' & /ba'ṇà// & 'make!' \\
\hline 'read!' & /pa'rèà/ & 'teach!' \\
\hline /bán/ 'tie!' & /ba'nà/ & 'get someone to tie!' \\
\hline /bád/ 'grow!' also 'tie!' & /ba'dàे/ & 'let grow!' also 'get someone to tie' \\
\hline /láng/ 'pass by!' & /lan'gà/ & 'shoot!' \\
\hline /sámy̌/ 'understand!' & /sam'jà̀ $/$ & 'give constructive criticism!' \\
\hline /káḍ/ 'remove!' & /ka'ḍà/ & 'get someone to remove!' \\
\hline
\end{tabular}

It is on the basis of such examples that we can posit the existence of a lexical $\mathrm{L}$ in the vicinity of the root coda. This hypothesis is of course supported by the existence of aspiration at the root coda in many Urdu cognates. I will assume that, in Gojri, an L tone that is historically due to a de-aspirated voiced consonant is underlyingly associated with 
the mora that immediately follows the de-aspirated consonant. Should there be no following mora; i.e. if the de-aspirated consonant is word-final, then $\mathrm{L}$ can be said to be 'floating' in the underlying form of the word.

The process described above by which verb roots such as those in (43) alternately feature high-falling and low-rising melodies is represented with greater precision in (44)(45) for the root /bán’ 'become!'. In (44), a 'floating' L (circled) is shown as being part of the word's underlying form: ${ }^{2}$

$$
\text { The underlying form of /báṇ/ 'become!' }
$$

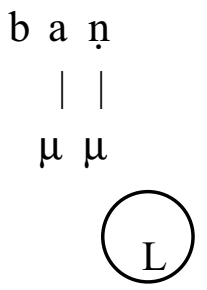

In the absence of a following mora, the floating L docks on the final mora of the root. Next, default $\mathrm{H}$ is associated with the remaining empty mora, creating the HL sequence shown in (45). The HL sequence then precipitates a high-falling melody commencing at an extra-high pitch on the first mora and resolving in a mid pitch on the second mora. The surface form of /báṇ/ 'become!'

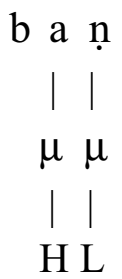

With the addition of the inherently stressed causative suffix $/-\bar{a} /$, floating lexical L docks on the mora immediately to the right of the de-aspirated consonant, as shown in 
(46). $\mathrm{H}$ is then assigned to the remaining mora of the stressed second syllable, creating an LH sequence. The underlying LH sequence precipitates a low-rising melody on the second syllable, which commences at an extra-low pitch on the first mora and resolves in a mid pitch on the second mora. Since there is no $\mathrm{L}$ or $\mathrm{H}$ in the unstressed syllable, the phonetic result is a mid pitch on that syllable.

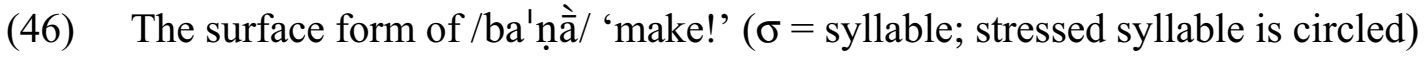

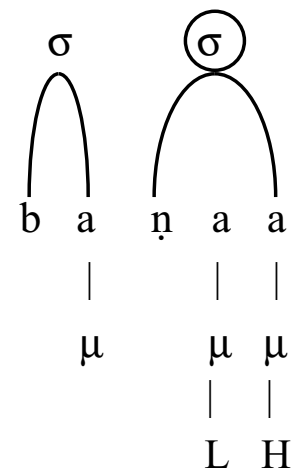

\subsubsection{Low Tone Related to Loss of Initial Aspiration}

Perhaps the most striking phonological difference between Eastern and Western varieties of Gojri is the variation in voicing which is concomitant with low-rising tone. The variation involves word-initial plosives at all five points of articulation: /p/ (/b/), $/ \mathrm{t} /(/ \mathrm{d} /), / \check{\mathrm{c}} /(/ \breve{\mathrm{j}} /), / \mathrm{t} /(/ \mathrm{d} /)$, and $/ \mathrm{k} /(/ \mathrm{g} /)$. These are cognate with the Urdu initial voiced aspirates: /bh/, /dh/, /jh/, / $\mathrm{dh} /$ and /gh/, respectively. Eastern forms reflect both the deaspiration and devoicing of these older initial voiced aspirates, or 'breathy voiced stops' (Ladefoged \& Maddieson 1996:57-63). Western forms are also de-aspirated but remain voiced. For example, the Gojri word for 'horse', /'kòṛ/ (/'gòṛ/), is cognate with the Urdu /'ghorāa/. I have found that, in pronouncing words of this type in conversation with both Eastern and Western speakers, correct production of the low-rising tone, rather than 
correct voicing, is more critical to being understood. These segments remain voiced in both dialects in medial position (where they are rare), e.g. /u'gà̀rīi/fem. 'naked', /ka'ḍà / 'get [someone] to remove!'

Low-tone words attesting the East-West initial voicing distinction are shown in (47) for each of the five points of articulation.

(47) Low-tone words involving East-West initial voicing distinction

Articulation East-West correspondences (Western forms are shown in parentheses)

\begin{tabular}{|c|c|c|}
\hline$/ \mathrm{p} /(/ \mathrm{b} /)$ & /'pà̀bī/ (/'bà̀ $\overline{1} /)$ 'brother's wife' & /'pà̀rū/ (/'bà̀rū/) ‘sheep and goats' \\
\hline$/ \mathrm{t} /(/ \mathrm{d} /)$ & /tàr/ (/dàr/) ‘set down!’ & /tìk/ (/dìk/) 'push!' \\
\hline /t/ / (/ḍ/) & /țàk/ (/ḍàk/) ‘cover!’ & /'țà̀ks/ (/'ḍà̀ks/) 'mountain' \\
\hline$/ \check{\mathbf{c}} /(/ \check{\mathbf{j}} /)$ & /'čòțo/ (/'jòtọ/) 'male buffalo' & /'čà̀nthhī/ (/'jà̀nthhī/) 'stick' \\
\hline$/ \mathrm{k} /(/ \mathrm{g} /)$ & /kàl/ (/gàl/) 'pour!' & /k商/ (/gàे/) ‘grass' \\
\hline
\end{tabular}

For all words attesting the initial voicing distinction between dialects, I assume that $\mathrm{L}$ is linked with the mora immediately following the historically de-aspirated consonant. This is the place in the lexical structure that was previously characterized by the lowering of pitch following breathy voicing. The derivation of surface tone for such words is shown in (48) below.

When the first syllable of such a word is stressed, the assigment of $\mathrm{H}$ on the second mora creates an LH sequence. The LH sequence precipitates a low-rising melody that commences at an extra-low pitch on the first mora and resolves in a mid pitch on the second mora. 
(48) Derivation for /'kòṛ̂/ (/'gòṛ̂/) 'horse'

a) Location of underlying $\mathrm{L}$

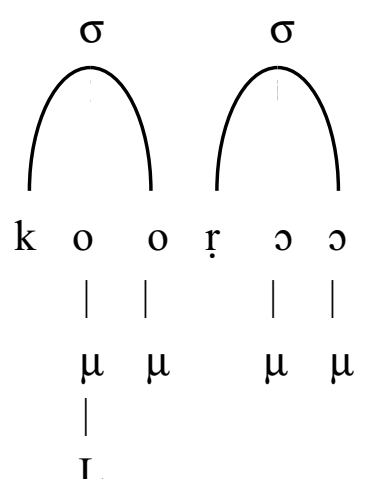

b) Results of H-assignment

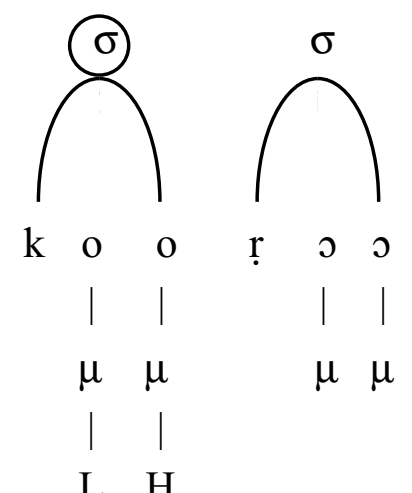

When such words are stressed on a subsequent syllable, the low-rising melody occurs on that syllable and a level low pitch occurs on all preceding syllables. Some examples are shown in (49).

(49) Cross-dialectal voice variation for words featuring non-initial low-rising tone

\begin{tabular}{|c|c|c|c|}
\hline Eastern & E. Phonetic & Western & Gloss \\
\hline /pìgē'āṛ/ & [pìgè:'à:ṛ] & /bìgīiāậ/ & 'wolf' \\
\hline /pù'kam/ & [pù'kňm] & /bà'kham/ & 'earthquake' \\
\hline & & $\begin{array}{l}\text { (the Allaiwal } \\
\text { aspiration) }\end{array}$ & Muhajar variant has no \\
\hline /pà'ṛās/ & [pò'ṛă:s] & /bà'ṛās/ & 'steam’ \\
\hline /pà'ṛā̄i / & [pì'ṛă:y] & /bà'ṛāy/ & 'miller's share' \\
\hline /pà'tī ǰj/ & [pì'tì:jó] & /bà'tījo/ & 'nephew' \\
\hline /dè'āṛo/ or /tè'āṛo/ & [dè:'à:róó] & /dì̀āṛo/ & ‘day’ \\
\hline
\end{tabular}

The level low pitch preceding the low-rising contour is readily observed in the contrast

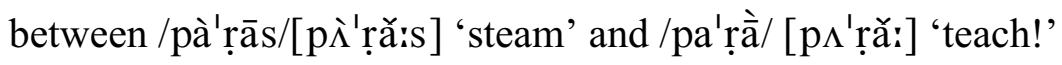




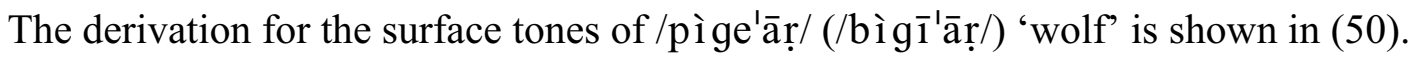
(50) Derivation for /pì ge'ārẹ/ (/bìg $\overline{1}^{\prime}$ āṛ /) 'wolf’ (L-spread indicated by diagonal lines)

a) Location of underlying $\mathrm{L}$

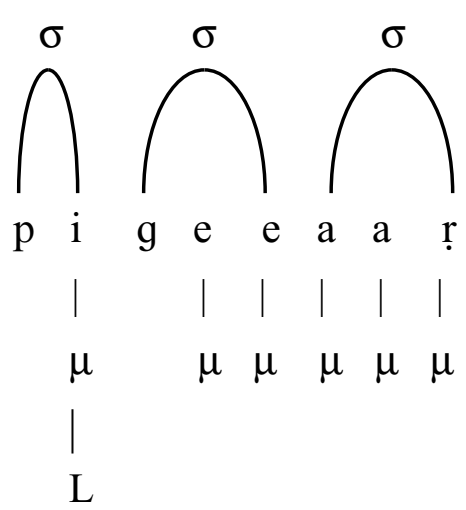

b) Results of L-spread and H-assignment

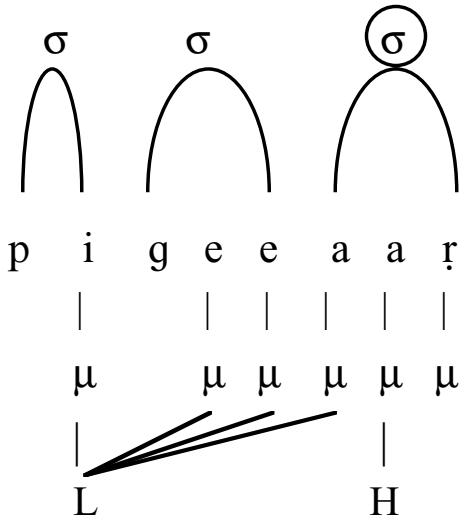

In (50)a, $\mathrm{L}$ is shown as being pre-linked in the lexicon to the first mora, the vowel $/ \mathrm{i} /$. In (50)b, the third syllable (the last 'heavy' syllable) is shown as being stressed. L spreads right-ward from its lexical location to a point up to and including the first mora of the stressed third syllable. Next, $\mathrm{H}$ is assigned to the remaining mora of the stressed syllable, resulting in an LH sequence in the stressed syllable. On moras preceding the stressed syllable, the spread of L produces a phonetic level low pitch. In the stressed syllable, the LH sequence precipitates a low-rising surface melody which commences at an extralow pitch on the first mora and resolves in a mid pitch on the second mora. For words

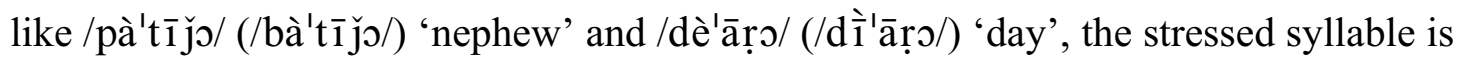
penultimate and so the low-rising melody resolves in the suffixal ultima, i.e. [pì'tì:ǰ́s], [dè:'à:róó]. 


\subsubsection{Summary of Analysis}

The analysis that has been presented so far can be summarized as follows.

(1) Stress Placement:

- The last heavy syllable of the word is stressed; if there is no heavy syllable, the penultimate syllable is stressed; the last segment of the word is disregarded in the determination of syllable weight.

- The causative suffix is always stressed; this fact overrides stress placement based on syllable structure.

-There is only one stress per word, no matter whether the word is monomorphemic or morphologically complex.

(2) Lexical L:

- In a root, one mora may be pre-associated in the lexicon with an L tone; some roots in the lexicon carry an L tone that is 'floating', i.e. it is underlyingly not associated with a specific mora. (Usually, an L tone occurs on the mora that immediately follows an historical voiced aspirate or $/ \mathrm{h} /$; if there is no following mora in the root, then the L tone floats.)

(3) L-spread:

- An L tone spreads right-ward from its underlying position in the word, up to and including the first mora of the stressed syllable. (By implication, this rule does not apply to an $\mathrm{L}$ tone that does not precede the stressed syllable.)

(4) L-docking:

- A floating L docks on the first mora of a following morpheme; if there is no following morpheme, a floating L docks on the final mora of the root. 
(5) Default H:

- $\mathrm{H}$ is associated with any empty mora in the stressed syllable; if there is no empty mora in the stressed syllable, then $\mathrm{H}$ is associated with the immediately following mora.

These basic rules account for the derivation of surface tonal melodies for all types of tone-bearing words in Gojri.

\subsubsection{Other Low-Tone Words}

In this section I describe low tone which is associated with initial $/ \mathrm{h} /$ and low tone related to the loss of medial $/ \mathrm{h} /$.

\section{Low Tone Associated with Initial $/ \mathrm{h} /$}

As noted in 2.1.5, low tone is concommitant with the glottal fricative $/ \mathrm{h} /$. This is most readily observed in the grammatical monosyllables /hàm/ 'we', /hù $\sim /$ 'I', and the

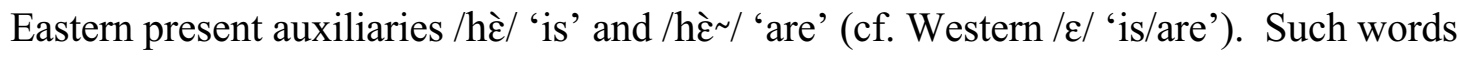
attest the linkage of lexical $\mathrm{L}$ with the mora following initial $/ \mathrm{h} /$. When a word beginning with $/ \mathrm{h} /$ is stressed on the first syllable, the frication is audible and the derivation of surface tone is identical to that shown for /'kòṛ/ (/'gòṛ/) 'horse' in (48).

However, when a word beginning with $/ \mathrm{h} /$ is stressed on a subsequent syllable, there is no friction and level low pitch occurs with every syllable preceding the low-rising pitch contour commencing on the stressed syllable. The phonetic differences attending change of stress from the first syllable to a subsequent syllable are most clearly shown by comparison of causative and non-causative forms of verbs beginning with $/ \mathrm{h} /$. Some examples are shown in (51). 
(51) Causative and non-causative pairs of verbs beginning with $/ \mathrm{h} /$

verb stem consisting of root verb stem consisting of root + causative suffix $/-\bar{a} /$

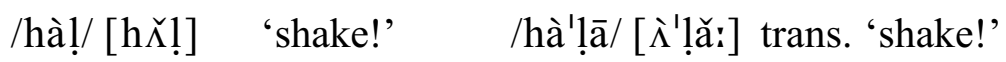

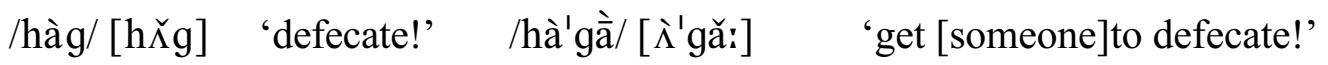

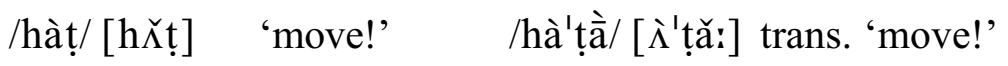

Some examples with polysyllabic stems are given in (52). For all these words and the causative verbs in (51) above, the derivation of surface tone (via L-spread) is identical to that shown for /pìge'āṛ / (/bìgīinạr/) 'wolf’ in (50).

(52) Words beginning with $/ \mathrm{h} /$ that are stressed on a non-initial syllable.

\begin{tabular}{|c|c|c|c|}
\hline /hà'sāb/ & [î'sǎ:b] & 'account' & cf. Urdu /hi'sāb/ \\
\hline /hà'zār/ & [î́zǎ:r] & 'thousand' & cf. Urdu /ha'zār/ \\
\hline /hà'mešā / & 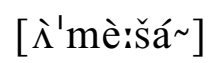 & 'always’' & cf. Urdu /ha'mešā/ \\
\hline /hàm'zoḷ/ & [ìm'zò:ló] & 'age mate (masc.)' & \\
\hline /hà'rīṛ̂/ & [ì'rrǔr ṛ] & 'a medicinal herb' & \\
\hline
\end{tabular}

There is evidence suggesting that the unstressed, low-pitch first syllables of words like those in (52) (which also lack a phonetic onset) are vulnerable to elision and loss. For example, some speakers pronounce /hà'vā/ 'wind' as monosyllabic [vă:]. Such loss also accounts for the difference between the Eastern /làl/ 'slay!' and the Western cognate /hì'lāl/. The process is also attested by Western copular forms like /wè go/ '(he) will be' (Eastern /'hòwe kə/), in which lexical L is all that survives of the verb stem /hò/ 'be' and presumably epenthetic /w/ has become word-initial (Western /wèṇo/ 'to be;' cf. Marwari /vheṇo/ 'to be', Masica 1991:104). Likewise, the genitival first plural pronoun /'mà̀ro/ 'our' surely represents the loss of a weakened first syllable from an older form attested 
by the Urdu cognate, /ha'mārā/, with retention of the L tone which was associated with that syllable.

Low Tone Related to Loss of Medial /h/

A large number of Gojri words feature the low-rising pitch contour in a first syllable consisting of consonant + long vowel in which the consonant is constant crossdialectically. These words are cognate with Urdu words in which $/ \mathrm{h} /$ occurs between a first-syllable short vowel and a second-syllable long vowel. The origin of the low tone for such words cannot be the de-aspiration of old initial voiced aspirates, since there is no East-West voicing variation for the initial consonant and the set of initial consonants is not limited to just stops. Rather, it appears that the historic erosion of medial $/ \mathrm{h} / \mathrm{and}$ related loss of preceding short vowels has left a trace in the form of an L tone associated with the initial mora. The derivation of surface tones for such words is therefore identical to that noted for words like /'kòṛ̂/ (/'gòrọ/) 'horse' shown in (48).

(53) Low-tone words attesting loss of medial /h/ before long-vowel

\begin{tabular}{|c|c|c|}
\hline Gojri word & Gloss & Urdu cognate (or source in most cases) \\
\hline /mà̀l/ & 'Mahal, palace' & /ma'hāl/ \\
\hline /'kà̀n̄ī/ (/'gà̀n̄în/) & 'story' & /ka'hān̄il/ \\
\hline /pà̀r/ & 'mountain' & /pa'hāṛ’ \\
\hline /jà̀z/ & 'ship' & /ja'hāz/ \\
\hline /'swà̀gā/ & 'ashes' & /su'hāge/ \\
\hline /'mì̀no/ & 'month' & /ma'hīnā/ \\
\hline /'bàdar/ & 'brave' & /ba'hādar/ \\
\hline /jà̀d/ & 'jihad’ & /ju'hāad/ \\
\hline /'mà̀̆ar/ & 'refugee' & /mu'hājir/ \\
\hline /sà̀l/ & 'diarrhea' & /sa'hāl/ \\
\hline /lòr/ & 'Lahore’ & /la'hor/ \\
\hline /'bà̀no/ & 'excuse’ & /ba'hānā/ \\
\hline
\end{tabular}


For a small number of words, stress falls on a non-initial syllable and surface tones attest a medial, rather than initial, lexical L. Examples include /dāde'àlı [da:de'ǎ:! ] 'paternal relatives' (cf. /'dādə/ 'paternal grandfather' and /'ālāa (/'hà̀ḷā/) 'ones of ...'), and

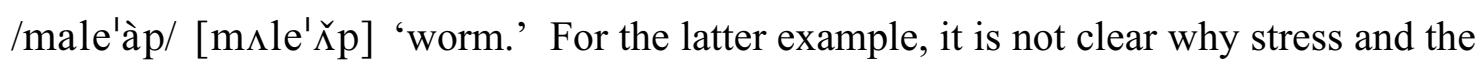
low-rising tone occur on the short-vowel ultima.

\subsubsection{Other High-Tone Words}

Whereas low tone almost always derives from initial lexical L, high tone derives from medial or final lexical L. The historical source of lexical $\mathrm{L}$ in a given word is generally less transparent than it is for the various kinds of low-tone words described above.

In addition to the high-tone verbs described in 3.1.2.3, there are other high-tone words for which high tone is associated with the loss of aspiration in a non-initial voiced aspirate. Some examples are shown in (54). The de-aspirated consonants remain voiced in both dialects. There are no Gojri words featuring a high-falling tone with a short vowel preceding a final voiceless consonant.

(54) High-tone words associated with de-aspiration of non-initial voiced aspirates

\begin{tabular}{|c|c|c|}
\hline /dúd/ & 'milk' & cf. Urdu /dudh/ \\
\hline /'čódrīi/ & 'Choudhry' & cf. Urdu /'čodhar $\overline{1} /$, title taken by prominent Gujars \\
\hline /kúj/ & ‘some’ & cf. Urdu /kučh/ \\
\hline /'búḍ̄î/ & 'old woman' & cf. Urdu /'burhīi / \\
\hline /'dấr̄î/ & 'beard' & cf. Urdu /'dāṛhī/ \\
\hline /rúr / & 'roll' & \\
\hline /'káṝi/ & 'boiled butter & nilk’ \\
\hline
\end{tabular}

For all such monosyllables, $\mathrm{L}$ is floating in the underlying form of the word, and the derivation of surface tones is identical to that shown above for /báṇ/ 'become!' in (47)(48). For all such two-syllable words, $\mathrm{L}$ is pre-linked in the lexicon with the mora 
following the de-aspirated consonant. Default $\mathrm{H}$ tone is then assigned to the single mora of the stressed first syllable, creating an HL sequence that is realized phonetically as a high-falling melody spread over the two syllables. The underlying and derived forms of /'búḍ̂̄/ 'old woman' are shown in (55).

Derivation for /'búḍ̄i / 'old woman'

a) Location of underlying $\mathrm{L}$

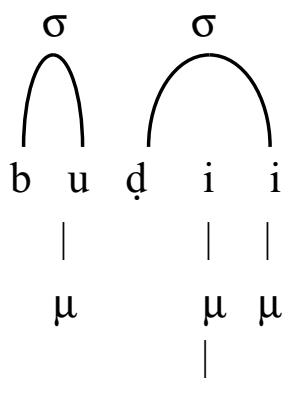

$\mathrm{L}$ b) Results of H-assignment

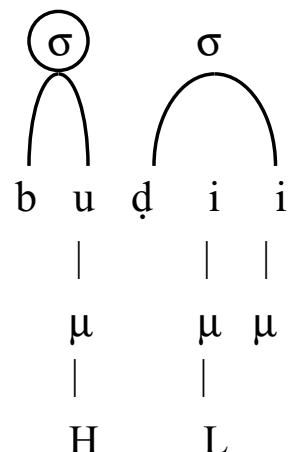

Almost all other indigenous high-tone words involve lexical L following a medial or final long vowel. The sources of lexical L include loss of /s/ (e.g. /b $\frac{1}{1} /$ 'twenty' vs. Urdu /bīs/) and loss of /h/ (e.g. /čá/ 'want' vs. Urdu /čāh/). Many high-tone stems such as /gấk/ 'customer' (Urdu /'gāhuk/) represent the loss of medial /h/ after a long vowel along with loss of the following unstressed short-vowel syllable and subsequent association of $\mathrm{L}$ with the end of the long vowel. Some examples of high-tone words attesting medial or final $\mathrm{L}$ are shown in (56).

(56) Contrast between high-falling and level tonal melodies

\begin{tabular}{|c|c|c|c|}
\hline /'ḍóḷo/ & 'upper arm' & /'̣̣oḷ/s/ & 'large water pot' \\
\hline /'sấyo/ & 'rabbit' & /'sāyo/ & 'shadow' \\
\hline /'mắnǰ̄i / & 'one who tends bufalo' & /'mānǰ̄i/ & 'bride's guests' \\
\hline /máa/ & '2nd month of lunar calendar' & $/ \mathrm{mā} /$ & 'mother' \\
\hline /'bóț̣i/ & 'bride' & /'boṭ̂1/ & 'piece of meat, kabob' \\
\hline
\end{tabular}




$\begin{array}{llll}\text { /čà/ } & \text { 'want!' } & \text { /čā/ } & \text { 'lift!' } \\ \text { /zấr/ } & \text { 'poison, saliva' } & / z \bar{a} r / & \text { 'Darling' } \\ \text { /báa } & \text { 'arm' } & \text { /bā/ E.only ' 'water hole, dam' }\end{array}$

The derivation of surface tone for such words is shown in (57) for /'bóṭ̂̄ / 'bride.'

(57) Derivation for /'bóțī/ 'bride' (stressed syllable is circled)
a) Location of underlying $\mathrm{L}$
b) Results of H-assignment
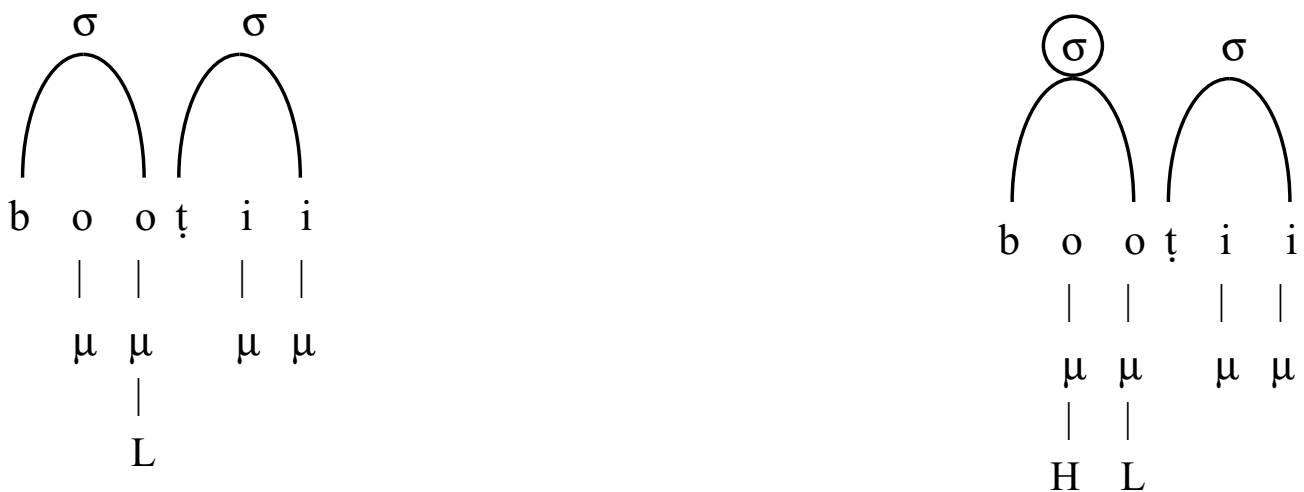

In $(57) \mathrm{b}$, an HL sequence is created by the assignment of $\mathrm{H}$ to the first mora of the stressed syllable, the mora which immediately precedes lexical L. The HL sequence precipitates a high-falling melody which commences on the stressed syllable and resolves in the following suffixal syllable. For monosyllabic words like /bấ/ 'arm', the high-falling melody commences on the first mora and resolves on the second mora of the root vowel. I have not investigated the historical antecedents of lexical L for these words, nor is such information needed to determine the location of $\mathrm{L}$ within words.

\subsubsection{Low Tone Co-occurring with Aspiration}

For a few words such as those in (58), low tone co-occurs with aspiration. In my research to date, all instances noted involve the segment $/ \mathrm{th} /$. 
(58) Co-occurrence of low tone and aspiration

$$
\begin{aligned}
& \text { /'thà̀ṇo/ ['t } \mathrm{t}^{\mathrm{h}} \mathrm{a} \text { :ṇó] 'to be found' } \\
& \text { /'thà̀ro/ ['thà̀ró: ] pl 'your' }
\end{aligned}
$$

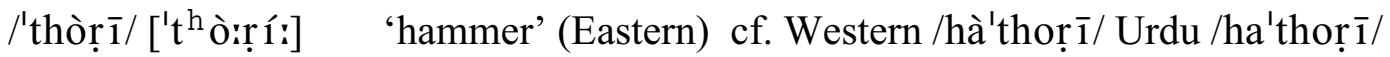

$$
\begin{aligned}
& \text { /'thà̀raf/ ['t' }{ }^{\mathrm{h}} \text { à̀ráf] 'introduction' cf. Urdu /'tāraf/ }
\end{aligned}
$$

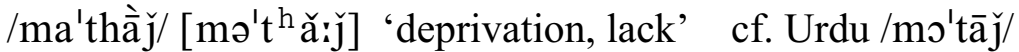

Only for the Eastern word /'thòr $\mathbf{1} /$ 'hammer' is the origin of lexical L transparent (from comparison with cognates retaining an initial $/ \mathrm{h} /$ ). Further research is likely to reveal the source of $\mathrm{L}$ for the other examples shown here. Words showing that low tone is not automatic with /th/ include /'thoṛ̂̄/ 'a little (fem.)' and /'thāno/ 'police station.'

Elsewhere, low tone and aspiration contrast. Some examples include/țànḍ/ 'still water' vs. /ṭhanḍ/ 'cold', /kàl/ 'pour!' vs. /khal/ 'stop, wait!', and /'čàtī ('mārṇī)/ '(playing) peek-a-boo' vs. /'čhātī / 'chest, upper torso.' This contrast is limited to the Eastern dialect, since the initial consonants of the corresponding low-tone words in the Western dialect are voiced rather than voiceless.

\subsection{Representation of Gojri Tone}

\subsubsection{Tone Marking in Orthography Design}

While the literature on tone marking is not extensive, recent empirical studies in African tonal languages by Bird and others he cites (1997) demonstrate that exhaustive marking of surface tone is detrimental to fluent reading, as is 'zero marking' - ignoring tone altogether. The former extreme is born of the traditional compulsion to represent every phonemic contrast in the orthography, but often results in solutions that are cumbersome and notoriously difficult for mother-tongue readers to master. The latter extreme rightly acknowledges the ability of readers to identify words based on contextual 
and other clues, but in many languages leaves readers to 'stumble and guess unnecessarily' (Bird 1996, citing Nida 1964:27). The compromise approach advocated by Bird (1996) on theoretical and experimental grounds involves representing the underlying or 'lexical' tone elements while maintaining a constant word image, given that 'post-lexical' spell-out is phonologically predictable and presumably automatic for linguistically naive mothertongue readers. Such an approach has the added advantage of tending to minimize dialect differences (Bird 1996:25), and is even more promising for languages like Gojri in which the tone pattern of each word remains basically constant (i.e. is not very sensitive to phrasal influences).

A fourth approach would mark tone only when necessary for disambiguation, much as Urdu diacritics indicating vowel quality are normally employed only to distinguish ambiguous pairs. This would necessarily involve special tone diacritics, as optional writing of tone graphemes (letters) in a linear and cursive Perso-Arabic representation would largely preclude maintenance of fixed word images. Marking tone with diacritics would avoid this problem, allowing for optionality in books and complete tone marking in primary literacy materials. In my opinion, however, a diacritic solution is inferior to that suggested by the correspondence of Gojri lexical L with Urdu /h/ and aspiration (with voiced consonants). Given the influence of Urdu and literate Gujars' familiarity with Urdu spellings, a representation that maintains fixed word images between Gojri and Urdu cognates has the greatest potential to facilitate transitional literacy and the acceptance of Gujar literature among Urdu-literate Gujars. The challenge then is to achieve a solution that utilizes Urdu-based spellings in a consistent representation of underlying rather than surface Gojri tonal facts. 


\subsubsection{Evaluation of Conventions In-Use}

Orthographic solutions to date have all attempted, whether consciously or unconsciously, to represent Gojri tones as per the representation of their cognate segments in Urdu: by means of do chashmi he, denoting aspiration, and choti he, $\diamond$, (rendered /nik $\overline{1}$ hè/ in Gojri) denoting the voiceless glottal fricative $/ \mathrm{h} /$. One common pattern is for literate Gujars to slavishly write Gojri as they write Urdu, with no awareness of Gojri tonal phenomena. In writing of this type, tone is usually only represented, albeit accidentally, in tonal words that have known Urdu cognates. Tone is usually ignored in words that are uniquely Gojri, because writers are both unaware of tone and lacking any technique for transcribing it. Some literate Gujars intuitively identify tone as aspiration, and by analogy to known Gojri-Urdu cognate relationships will write this 'aspiration' on uniquely Gojri words (their pronunciation of Urdu may reflect this identification, i.e. they convert instances of $\mathrm{Urdu} / \mathrm{h} /$ and aspiration into low-rising and high-falling tone melodies). In my experience, the writing produced by both types of literates is highly idiosyncratic and inconsistent from one occurrence of a word to the next. High tones occurring with medial long vowels tend to get particularly ignored, since cognate relationships of such words with Urdu words are comparatively less transparent.

Among the few who are aware of tone and consciously reflect on how to write it, some, in keeping with the default tendency to write words the way they sound, attempt to represent all of the surface tonal contrasts. (An additional motivation, that of making the representation phonetically transparent for learners of Gojri as a second language (Sharma 1979:150), is minimized here because, as we shall see, it is at odds with the Gujars' own needs for a representation that potentially works for both dialects and that 
maximizes ease of reading skill transfer to and from Urdu.) The difficulty with writing surface tones lies in determining which of the two Urdu letters should represent which tonal pattern in a given context. The problem is exacerbated by the fact that even for Urdu their employment has only recently been standardized, with do chashmi he now prescribed for all aspiration and choti he for all instances of /h/ (Mathews 1999:xxvi). It should be evident from the variety of tone phenomena described above, however, particularly from that shown in 3.1.2.3, that the traditional ideal of consistently representing one toneme with one grapheme while maintaining constant shape of lexical roots is not achievable for Gojri (e.g. the addition of the causative suffix turns a high tone verbal root into a low tone stem). Furthermore, since the mapping of Gojri toneme to Urdu phoneme/grapheme is not one-to-one, at some point a surface representation must compromise in favor of either the Urdu spellings or tonemic-graphemic correspondence.

\subsubsection{Writing of Low Tone Occurring with Initial $/ \mathrm{h} /$ in Monosyllables}

If there is any 'given' or non-negotiable convention which can be taken as a starting point for either an underlying or surface approach to tone marking (aside from leaving the level tone unmarked), it is the representation of word-initial low-rising tones, concommitant with $/ \mathrm{h} /$ in monosyllables, with choti he. This decision is largely unconscious and is based on the spelling of Urdu cognates. The practice is nearly universal in Gojri writing. Since initial /h/ in Gojri monosyllables is always followed by the low-rising tone, this decision would tentatively associate choti he with the low toneme or lexical L, depending upon one's perspective. Thus, the first person pronouns and present auxiliaries, together the highest frequency words involving tone of any kind, remain constant between the two languages: 
(59) Uniform spellings for Gojri and Urdu first person pronouns and present auxiliaries Gojri /hàm/ [ȟ̌m] 'we' $\quad$ vs. Urdu /ham/ [hım] 'we'

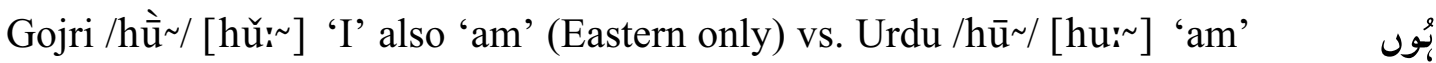
Gojri /hò/ [hǒ:] 2pl. 'are' (Eastern only) vs. Urdu /ho/ [ho:] 2pl. 'are' و

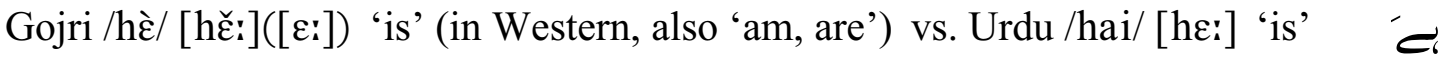

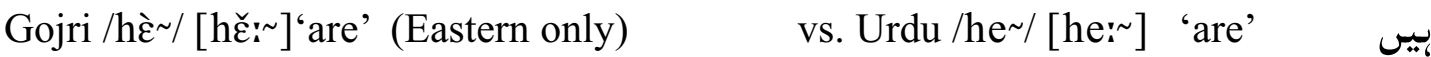

\subsubsection{Surface Approach to Low Tone Related to Loss of Initial Aspiration}

Extending the association of choti he with low tone here to the possibility of its representation of low tone everywhere leads next to an evaluation of its suitability for low tones resulting from the de-aspiration of initial voiced aspirates (see 3.1.2.4 above), e.g. writing /kàे// (/gàे/) 'grass' as كها. Such an approach is advocated by Sharma (1979:150; 2001: personal communication) and has been utilized in Pakistan by Sabir Afaqi and his associates. The impetus behind this convention is the desire to represent the initial consonant as de-voiced, per its Eastern pronunciation, while avoiding the intolerable ambiguity with voiceless aspirated segments that would result from using $d o$ chashmi he for the following low-tone vowel. For example, /kàे/ (/g⿳亠े⿵冂𠃍八口) 'grass' and /khā/ 'eat!' would both be written as كها.

Unfortunately this approach has its own problems. First and most obviously, since the segments in question remain voiced in the Western dialect, the use of choti he in these contexts unnecessarily precludes the possibility of a single representation for both dialects. This problem by itself may not be of great concern to Eastern writers, who are 
seldom if ever exposed to Western speech. It can be demonstrated, however, that the approach is problematic even for the Eastern phonology because it creates unnecessary ambiguity between certain low-rising and high-falling pairs of tonal words; for example,

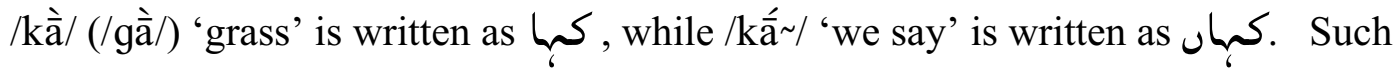
ambiguity is particularly evident wherever low-rising and high-falling tones contrast within syllables featuring short (or written as short, as in the case of $/ \varepsilon /$ ) vowels. A few such ambiguous examples are shown in (60).

(60) Ambiguous Eastern low-tone/high-tone pairs

\begin{tabular}{|c|c|}
\hline /kàṭ/ & 'few' \\
\hline /'kéto/ & 'he (doesn't) say' \\
\hline /'kàṇ̄î/ & fem. 'many' \\
\hline /'kéṇ̄ī/ & fem. 'to say' \\
\hline /'pàlā/ & masc.pl. 'excellent' \\
\hline /'pélā / & 'before' \\
\hline /'tùn̄̄ / & 'navel' \\
\hline /'túmat/ & 'slander' \\
\hline
\end{tabular}

Granted, such ambiguities are few in number and would scarcely present any difficulty for Gujar literates, but the larger pattern they represent could be a serious challenge for new readers. The ambiguity issues from the fact that all Gujar writers have 
continued writing the verbs / $\mathrm{k}^{\varepsilon}-/$ 'say' and /ré-/ 'stay' as per their Urdu spellings, i.e. with the initial consonant joined to choti he, but without writing the vowel / $/$ / (Urdu /ah/, approximating but shorter than /ai/ +/h/). By itself, representing the Gojri segment / $\varepsilon /$ with choti he is good, since morphophonemic changes alter $/ \varepsilon /$ in a majority of contexts anyway, and this practice allows the lexical roots to remain constant in writing before any suffixed vowel. Furthermore, it also maintains a constant word shape between the two languages. For example, Urdu /ra'ho/ and Gojri /ró/, 'stay!' can both be represented by ريو (cf. 5.2).

This convention, however, together with using choti he for low tones resulting from the de-aspiration of initial voiced aspirates, perpetuates an ambiguous system in which, given the unusually high frequencies of / $\mathrm{k}^{\prime}-/$ 'say' and /ré-/ 'stay' in Gojri text (the latter being an important grammatical morpheme), the new reader has to memorize which instances of choti he indicate which type of tone. And of course the transitional reader must learn two spellings (Gojri and Urdu) for a great many pairs of cognates like those for

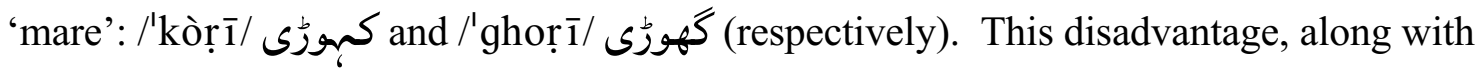
the introduction of ambiguity between representations of high-tone and low-tone short vowels, constitutes compelling grounds to consider better orthographic solutions - even for the Eastern phonology. 3 


\subsubsection{Writing of $/ \hat{\varepsilon} /$}

The preceding discussion, however, may be enough to establish a second orthographic 'given', namely, that the segment /દ́l - cognate with Urdu /ah/ - is well represented by a choti he per the Urdu spelling convention (note: reducing ambiguity by writing the vowel $/ \varepsilon /$ would preclude a morphophonemic representation, since $/ \varepsilon /$ is always altered before vowel suffixes). This convention is followed in all Gojri writing. Some examples are shown in (61).

(61) / $/ \varepsilon /$ written with choti he and no other vowel letter

\begin{tabular}{|c|c|}
\hline /'réṇo/ & 'to stay' \\
\hline /'kéṇ๊/ & 'to say' \\
\hline /lér/ & 'anger' \\
\hline /béṇ̂ / & 'sister' \\
\hline /'méndī/ & 'henna' \\
\hline /bék/ & 'a roost' \\
\hline
\end{tabular}

Particularly from the perspective of surface tone marking, this practice may appear to contradict the first given, by which choti he is associated with initial low tones. Against any charge of ambiguity, however, is the fact that the distributions of initial and noninitial choti he are constrained such that no ambiguous spellings can be adduced. But if the approach that marks only underlying lexical L is adopted, there is no contradiction between these two 'givens.' The former can be seen as marking lexical L initially, which after L-spread and the assignment of $\mathrm{H}$ on the second mora of the stressed syllable will invariably precipitate the low-rising pitch contour. The latter can be seen as marking 
lexical L root-finally (it is lexically linked with the second mora of $/ \varepsilon /$ ), which after the assigment of $\mathrm{H}$ to the first mora of the stressed syllable (i.e. the root nucleus) will invariably precipitate the high-falling pitch contour. For the lexical tone-marking approach, then, choti he and do chashmi he do not represent two distinct tonemes; rather, they are allographs representing lexical L, and their distributions are constrained by Urdu spelling patterns rather than by surface tonal contrasts.

\subsubsection{Iconic Approach to Low Tone Related to Loss of Initial Aspiration}

Returning to the representation of low tones resulting from the de-aspiration of initial voiced aspirates, we now consider the remaining alternative, that of preserving the Urdu voiced aspirate spellings which consist of the voiced consonants joined to do chashmi he. For Eastern Gojri, such a solution is iconic rather than phonemic (cf. Bird 1996:35), since the consonants are voiceless in initial position. It has been adopted for Punjabi (Parvez 1996:47-54), the phonology of which is identical in this respect to that of Eastern Gojri. The leading proponents of this technique for Gojri have been the (Eastern-speaking) Gujar scholars associated with the Jammu \& Kashmir Academy of Art, Culture \& Languages. In the introduction to their Gojri Dictionary (1985) the editors explain that they have utilized the Urdu orthography, and that the Urdu digraphs for initial /bh/, /dh/,

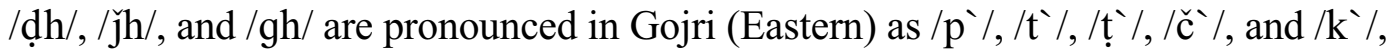
respectively. These scholars have applied this approach more or less consistently in their many Gojri publications. Its advantages should be clear by now, namely, that it offers a uniform representation for both dialects while maintaining a constant word image with Urdu and avoiding the ambiguities created by writing the consonants as voiceless (whether joined with choti he or do chashmi he). Consider the sample spellings in (62): 
(62) Spellings for low-tone words related to loss of initial aspiration word iconic spelling alternative phonemic spelling (E.only)

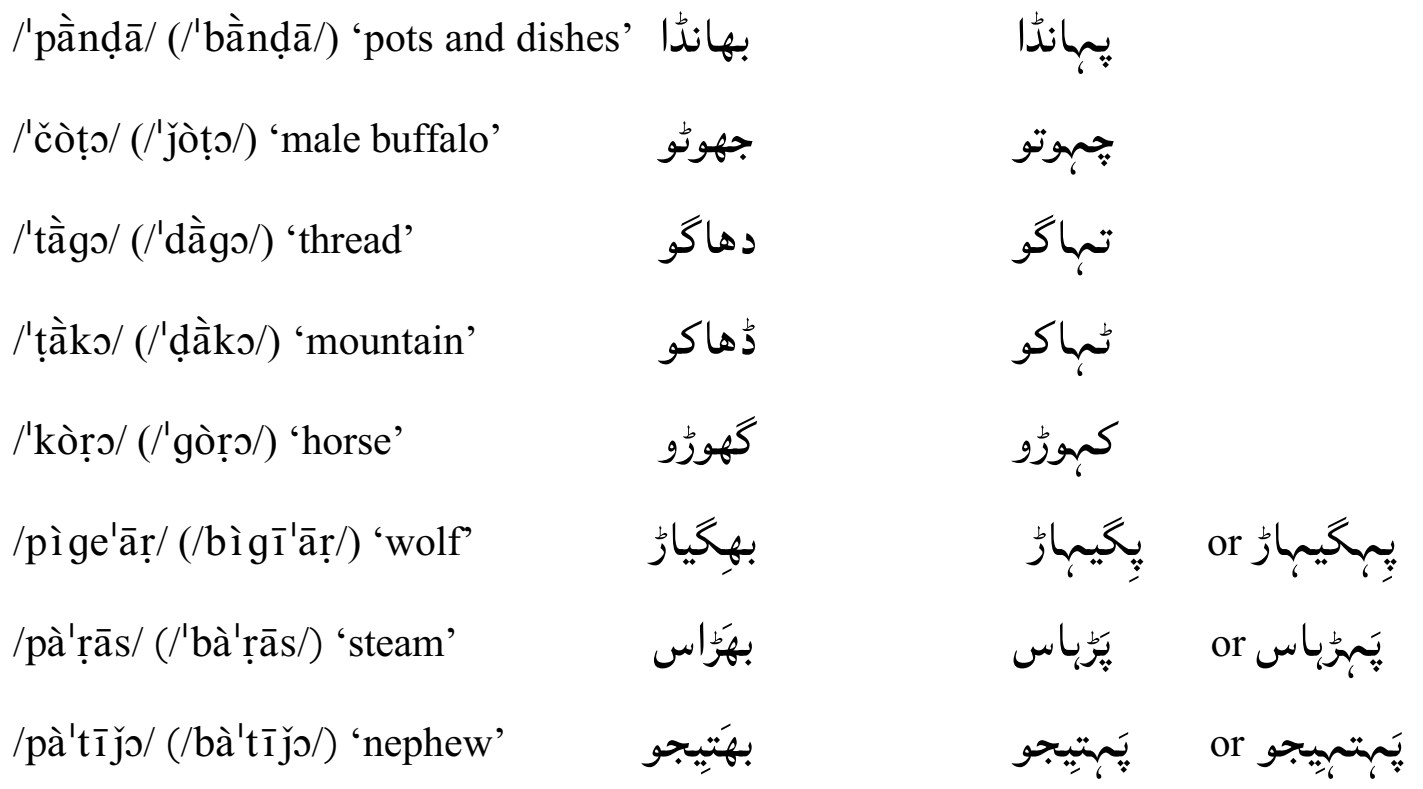

In my experience, Eastern literates in Pakistan (who have never seen their language in print) often reject this iconic solution upon initial exposure. They feel it is contrary to their distinct pronunciation, and say that the Western dialect doesn't concern them. However, Eastern speakers need not think that the iconic solution is based on the lowprestige Western dialect, but rather on Urdu, the high-prestige language of wider communication for Muslim Gujars in all locations. Thus, when presented with the ambiguities created by the alternative and the considerations for Urdu transitional literacy, their impression becomes favorable. The counter-intuitive nature of this solution thus underscores the need for orthography promotion, and for orthographic explanation in the introductions to Gojri publications and literacy materials.

As for pedagogical method, the five segments in question, along with the five voiceless aspirates, must be taught iconically as digraphs, i.e. as single alphabetic units. For 
example, new Eastern readers using the Gojri Alphabet Primer (Thikri \& Losey 2001) in Pakistan readily learn to associate the /gh/ digraph كه with the segment /k`/ by looking at the pictured horse, /'kòrı/. Similarly, they learn to associate the /kh/ digraph كه with the segment $/ \mathrm{kh} /$ by looking at the pictured donkey, /'khoto/. Eastern speakers already literate in Urdu need only a concise orthographic 'key', such as that contained in the Gojri Dictionary, when transitioning to Gojri text.

The solution detailed immediately above, then, is superior to its leading alternative, the phonemic solution proposed by Sharma (1979:150). To summarize, the problems with the phonemic solution are that it 'splits' the Eastern and Western dialects, complicates transitional literacy by precluding consistency of word images with Urdu, introduces ambiguities for short vowels even within the Eastern dialect, and at present enjoys comparatively little use. Furthermore, the phonemic solution is ill-equipped to represent the effects of L-spread on words like /pà'tī̌ ǰo/ (/bà'tījos/) 'nephew' and /pà'rāâs/ (/bà'ṛās/) 'steam.' To be consistently phonemic, awkward spellings like those on the farthest right in (62) would be needed to indicate that the first unstressed syllables also bear low tone (and are tonally distinct from words like /na't̄̄ ǰs/ 'result' and /pa'ṛà)/ 'teach!'). The iconic solution, by representing lexical L only (via familiar Urdu-ized spellings), enables readers to correctly interpret low tone from the beginning of the word through to the low-rising pitch contour on the stressed syllable, based on their innate awareness of stress. Given intrinsic merits such as this and the pervasive influence of the Academy's publications, the adoption in Pakistan and Pakistan-administered Kashmir of 
the iconic solution promoted by the Academy represents the best opportunity for the broader Gojri movement to achieve a standard, internally consistent representation.

\subsubsection{Writing of High-Tone Words (Other than / $/ \varepsilon /$ - Type)}

The remaining orthographic matters pertaining to tone have received relatively little attention to date, with writers typically defaulting to the Urdu spellings or, when words lack an Urdu cognate, often ignoring the tone entirely. This is probably because the remaining tonal phenomena occur less frequently and are more problematic than those considered thus far in this section. Sharma (1979:151) proposes that the high toneme be represented by do chashmi he written immediately after the vowel bearing high tone. This, however, would put the do chashmi he immediately after a consonant whenever the vowel was short (or perceived as short), given the practice of not writing high-tone (or otherwise) short vowels. This in turn would create many ambiguities with voiceless aspirates and low-tone segments, the latter rightly consisting of a (voiced) consonant followed by do chashmi he. Any related proposal (I know of none) for explicitly writing the short vowels and $/ \hat{\varepsilon} /$ would be problematic in view of the widely accepted practice of ignoring them or of writing / $/ \varepsilon /$ simply as choti he. Representing the short vowels with the appropriate diacritics would not reduce the ambiguities created by Sharma's proposal, since the consonants would still get joined to do chashmi he.

An Urdu-ized solution to the writing of high-tone words is suggested by two different spelling patterns for Urdu cognates. Both patterns are used for Gojri high-tone words when the spellings of such words are known from Urdu. These patterns are not, however, consistently applied to uniquely Gojri words. 


\section{Writing of High Tone Associated with Loss of Medial /h/}

The first and most common spelling pattern features choti he or bari he, $\tau$, (in the Arabic 'gentleman' and 'wedding ceremony' below) written after the high-tone long vowel, as shown in (63). It corresponds to the words shown in (56) in 3.1.2.7.

(63) High-tone words written with post-vocalic he, per spelling of Urdu cognates

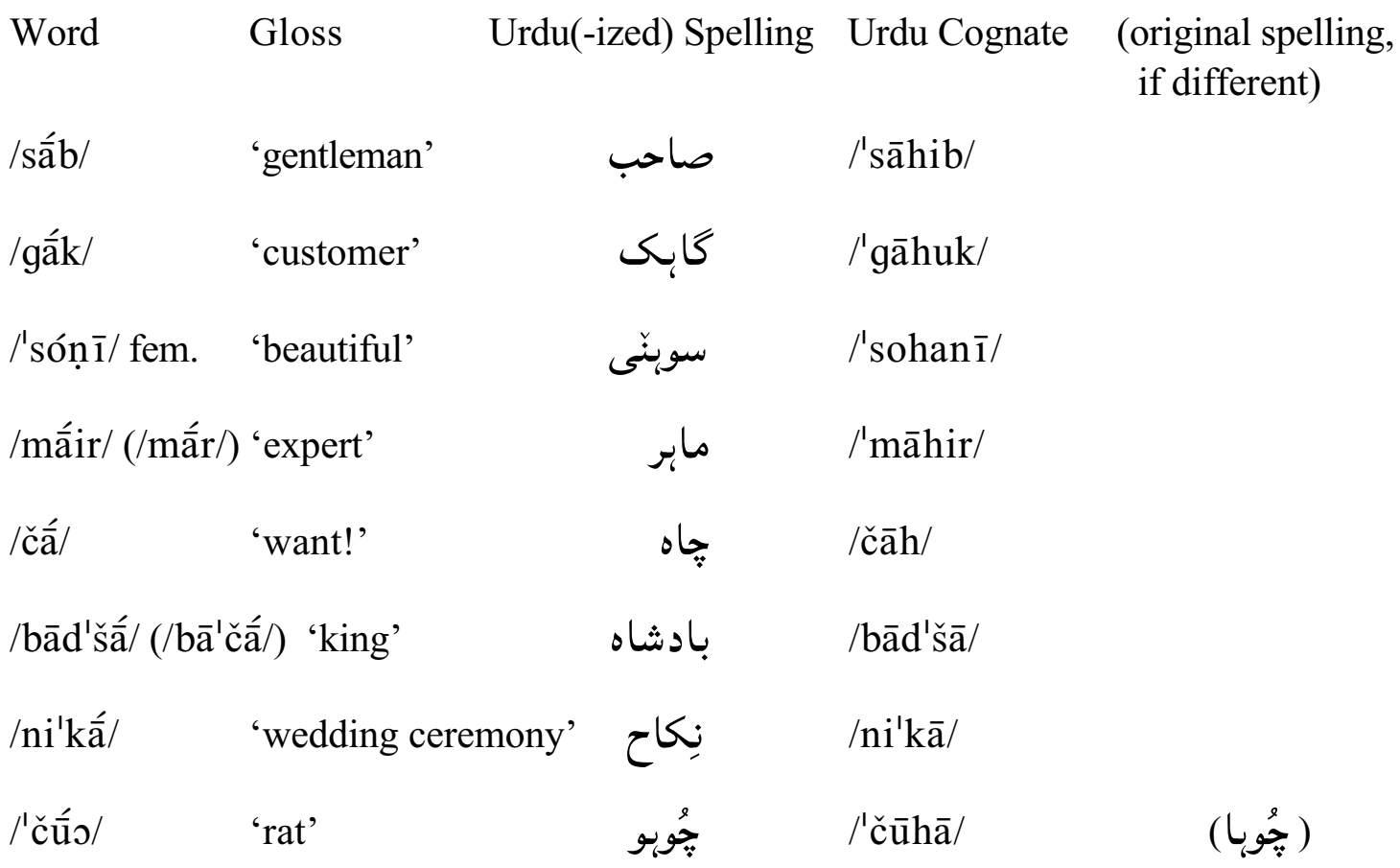

Uncommon in Gojri are high-tone medial short vowels having Urdu cognates other than the kind shown below in (64). Words featuring high-tone medial short vowels but lacking such cognates can be written with choti he after the vowel diacritic, by extension of this pattern and the pattern noted earlier for /ع́/, e.g. /'túmat/ 'slander' تُحهمت. 


\section{Writing of High-Tone Associated with De-aspiration}

The second, lower-frequency spelling pattern features do chashmi he after a voiced consonant, as shown in (64). It corresponds to the words shown in (54) in 3.1.2.7 and to the non-causative verbs presented in 3.1.2.3.

(64) High-tone words written with final do chashmi he, per spelling of Urdu cognates Word Gloss Urdu(-ized) Spelling Urdu Cognate (original spelling, if different)

\begin{tabular}{|c|c|c|c|}
\hline /kúǰl & 'some' & كُجه & /kučh/ \\
\hline /dúd/ & 'milk' & دُوهـ & /dudh/ \\
\hline /'dấṛ̣̂/ & 'beard' & دارٔهى & /'dāṛhī/ \\
\hline /'búḍ̄ī/ & 'old woman' & بُدْهى & /'buṛhī/ \\
\hline /'čódrīi/ & 'Choudhry' & جُوَدَهرى & /'čodhar $\overline{1}$ \\
\hline /páṛ/ & 'read!' & يَرْه هـ & /paṛh/ \\
\hline /sámǰ/ & 'understand!' & سَمجهر & /'samajh/ \\
\hline
\end{tabular}

The Urdu-ized spellings presented above for both patterns are superior to any surface spellings of high-tone words, despite variation in position and appearance. By representing the location of lexical L, whether by a post-vocalic choti he or final do chashmi he, such spellings clearly indicate the high-falling pitch contour to mother-tongue readers. Furthermore, these spellings maintain a relatively constant word image between Gojri and Urdu. The greatest advantage to adopting both patterns for Gojri, however, is that writing do chashmi he after formerly aspirated voiced consonants maintains a constant word image for many non-causative and causative pairs of Gojri verbs like those 
in (65). Any surface representation (whether representing the high toneme everywhere with post-vocalic do chashmi he or, better, with post-vocalic choti he everywhere given its prior association via / $\mathrm{k}^{\varepsilon}-/$ 'say' and /ré-/ 'stay') must resort to two surface spellings: one for the high-tone root and another for the low-tone causative. However, the Urduized representation of lexical L by means of post-consonantal do chashmi he enables readers to interpret high tone and, alternately, low tone from a single spelling of the root. Consider these examples:

Spellings for high-tone root and low-tone causative pairs of verbs

\begin{tabular}{|c|c|c|c|c|c|}
\hline verb pairs & & Urdu-ized spellings & alter & & ce spellings \\
\hline /pár! & 'read!' & يَرْه & يَمُْ & or & ليَهُر \\
\hline /pa'ṛà̄/ & 'teach!' & يَرِها & يَرْبِا & & \\
\hline /láng/ & 'pass by!' & لَنكه & & or & لَهُ \\
\hline /lan'gà̀/ & 'shoot!' & لَنكها & & & \\
\hline /báṇ/ & 'become!' & بَنْهُ & بَبهنْ & or & بَهُنْ \\
\hline /ba'ṇà / & 'make!' & بَنْها & & & \\
\hline /'bárạak/ intrans. & 'boil!' & بَرُهك & & or & بَهُرَ ك \\
\hline /baṛ'k䍏/ trans. & 'boil!' & بَرُهكا & & or & بَرُكها \\
\hline
\end{tabular}

The final pair in (65) is unique in that it shows the effect of L-spreading through an intervening root-final consonant and onto the stressed causative suffix. Only the Urdubased representation allows for correct indication of surface tones while avoiding 
awkward spellings which all but completely obscure any relationship between the two stems. An analysis mistakenly linking lexical $\mathrm{L}$ with root-final $/ \mathrm{k} /$ rather than with $/ \mathrm{r} /$ would lead to the spelling shown to the far right of the bottom line in (65), the final syllable of which is ambiguous with the aspirated level tone /khā/ 'eat!'

A similar pair of verbs are /póč/ 'arrive!' and /po'čà)/ 'deliver!' As indicated by its voicelessness, the root-final consonant has not been de-aspirated like those presented above. Rather, the root is a contraction of an older form attested by the Urdu cognate /pa'hunč/ 'arrive!' Writing lexical L with choti he after the vowel and before the final consonant accounts for L-spread through that consonant and onto the stressed causative suffix, while avoiding a spelling ambiguous with the aspirated level tone sequence /čhā/ (cf. /čhā / 'shade'). The spellings which correctly indicate surface tones are thus يَوبـج 'arrive!' and يَوبـجـا 'deliver!' Again, any other analysis and related spellings would complicate the interpretation of surface tones.

\subsubsection{Writing of Other Low-Tone Words}

Three remaining kinds of low-tone words warrant discussion, the first two involving a small number of words and the third constituting a much broader pattern.

\section{Writing of Polysyllabic Words Beginning with $/ \mathrm{h} /$}

The tone and spelling issues related to words like /pà't $\overline{1}$ jos/ (/bà'tī ǰo/) 'nephew' and /pà'rāàs/ (/bà'ṛās/) 'steam' are similar to those for words like /hà'mešāã / 'always' which were presented in 3.1.2.6. The latter begin with $/ \mathrm{h} /$ but are stressed on a non-initial syllable, and like the former words bear low tone on all syllables preceding the stressed 
syllable, followed by a low-rising pitch on the stressed syllable. Most Gujar writers simply write these words with initial choti he (e.g. بَميشاص /hà'mešā̃ / 'always'), per their familiarity with the spellings of Urdu cognates (e.g. بَميثـ /ha'mešā/ 'always'). This practice actually constitutes a 'shallow' orthographic solution and is often followed even by those normally advocating a phonetic approach to spelling. A surface representation would mark the low-rising tone where it is heard on the stressed syllable,

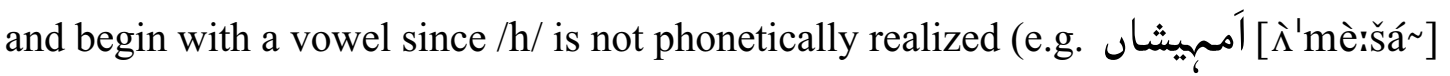
'always', in which the first-syllable low tone still remains unwritten). A natural application of this approach would spell the intransitive verb /hàl/ [hăl]‘shake!’ as بَّلّ , and its transitive (i.e. causative) counterpart /hà'lạâ/ [à'ḷăi] trans. 'shake!' as آلّها . Such spellings preclude a constant image of the Gojri root, as well as precluding a constant word image between Gojri and Urdu. The Urdu-ized practice of simply writing initial lexical L with initial choti he is the best solution for all words of this type.

\section{Writing Low Tone in Words Featuring Initial Aspiration}

Words in which low tone and aspiration co-occur (see 3.1.2.8) are most commonly written with reference only to aspiration. Thus, /'thàrı/ ['t $\mathrm{t}^{\mathrm{h}} \mathrm{àr}$ ró:] pl. 'your' is spelled تهارو and /'thà̀ṇo/ ['tha:ṇó ]'to be found' is spelled تهانو . An alternative phonemic approach representing both low tone and aspiration would yield awkward spellings for /thà̀rs/: تههبهارو or worse, تههارو . Ignoring the tone altogether is the best solution for such words, since only a handful are truly indigenous and lack accepted Urdu spellings. The interpretation of indigenous words like the two spelled above is greatly assisted by 
contextual clues (given the unique semantics of these two words), and I have not yet encountered any ambiguities between such words and aspirated level-tone words.

Writing Low Tone not Associated with Loss of Aspiration

This category includes all words with Urdu cognates featuring medial /h/ before a long vowel (see (53) in 3.1.2.6), as well as many which do not. The fact that Urdu medial /h/ corresponds to both Gojri high tone (3.1.2.7) and low tone (3.1.2.6) means that any phonemic spelling approach which values compatibility with Urdu is forced either to promote some spellings which are contrary to Urdu or to accept ambiguity in the interpretation of choti he. Since most Gojri words of the type corresponding to medial $/ \mathrm{h} /$ before a long vowel in Urdu are in fact Perso-Arabic loans whose spellings are wellknown to literate Gujars, there is little warrant for promoting unique Gojri spellings (although diacritics representing Urdu first-syllable short vowels must be omitted for Gojri). Examples of such loans are shown in (66).

(66) Spellings of Perso-Arabic loans pronounced with low tone in Gojri.

\begin{tabular}{|c|c|c|c|}
\hline Word & Gloss & Urdu Pronunciation & Urdu Spelling \\
\hline /màll/ & 'palace' & /ma'hāl/ & مَحل (with bari he) \\
\hline /jà̀z/ & ‘ship’ & /̌ja'hāz/ & \\
\hline /jà̀d/ & 'jihad' & / /̌ji'hād/ & \\
\hline /'mà̀̄ar/ & 'refugee' & /mu'hāǰir/ & \\
\hline
\end{tabular}

Along with such borrowed spellings, some Gujar writers, including the editors of the Academy dictionary, have been writing indigenous words of this type using do chashmi he by analogy with Urdu-ized spellings for low tones resulting from de-aspiration (see 
3.2.2.4). Others write all such words with choti he, consistent with their writing of low tones resulting from de-aspiration (by analogy with the spellings of loans like those in (66)). Some common words for which such alternate spellings are used are shown in (67).

(67) Alternate spellings for indigenous low-tone words not related to de-aspiration

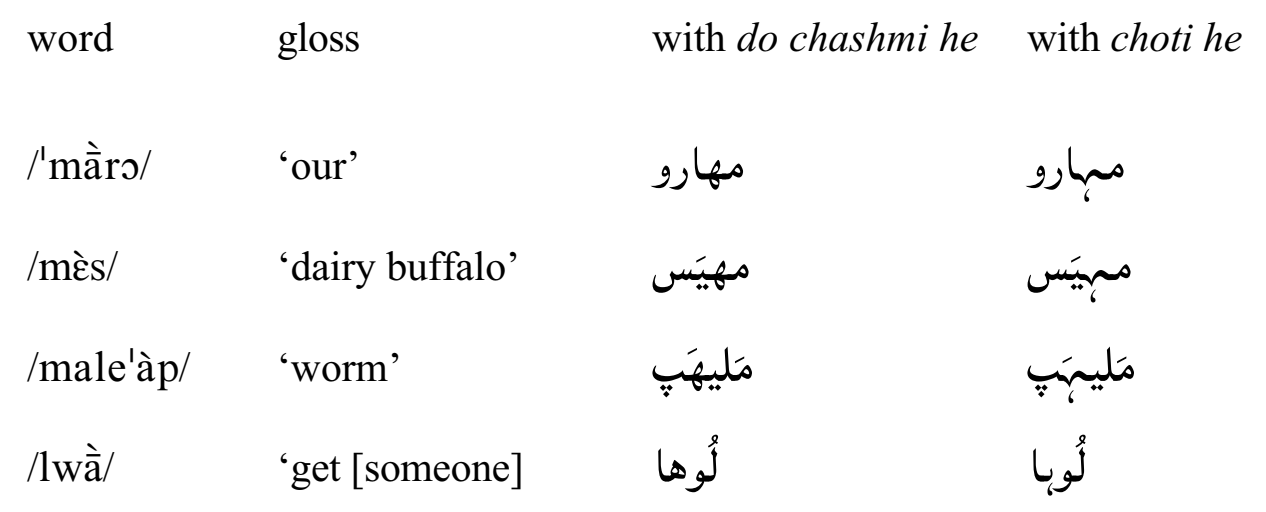
to remove [article of clothing]!' cf. oy /láa/ 'remove [article of clothing]!'

In between the words which are clearly loans and those which are truly indigenous are many more words which are not thought of as loans (and which might be indigenous) but whose Urdu cognates do have known spellings. For a small number of words like /'kàṇ̣̂/

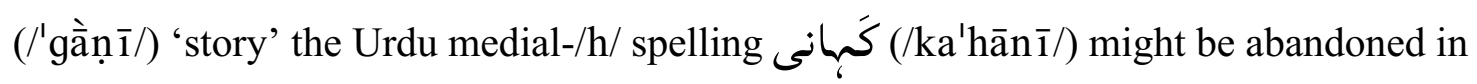
favor of كهانّى, so that both dialects can be represented by a single form. Conversely,

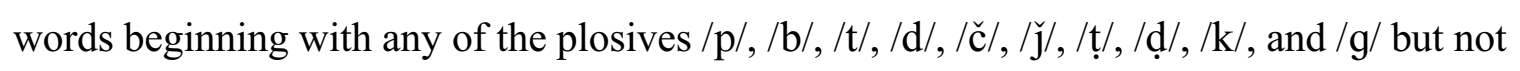
showing the initial voicing variation between dialects should always be written with the Urdu spellings to avoid confusion about voicing, e.g. بسكادر/'bàdar/ 'brave' (Urdu /ba'hādar/) and يمهُ /pà̀r / 'rocky crag' (Urdu /pa'hāṛ̣/ 'mountain'). For words beginning with any other consonant (i.e. any lacking a homorganic voiceless or voiced counterpart), there is no reason to promote a unique Gojri spelling (aside from unique 
Gojri endings), given the frequency of medial-/h/ loan spellings in the lexicon. In practice such words are typically written with Urdu spellings, but the do chashmi he spellings are also possible. Some examples of this variation are shown in (68).

(68) Alternate spellings for Gojri low-tone words cognate with Urdu medial-/h/ words

$$
\text { do chashmi he Spelling Urdu Spelling (with choti he) }
$$

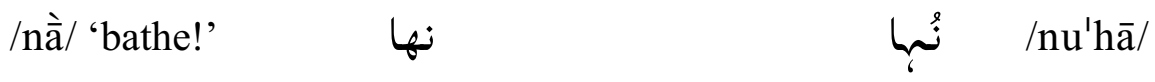

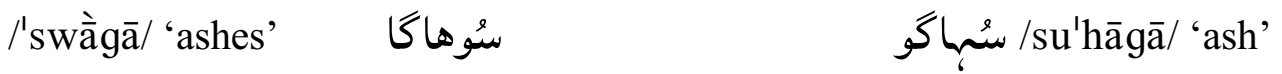

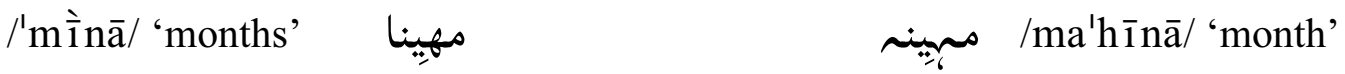

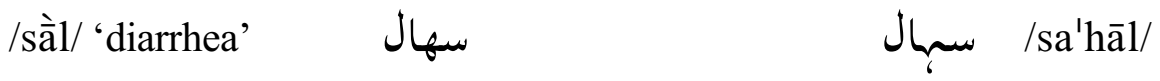

The remaining problem, then, is that there are two competing representations for unique Gojri low-tone words not resulting from de-aspiration. Since there are no lowtone roots featuring initial short vowels which are not the result of de-aspiration, neither choti he nor do chashmi he written before a long vowel create any ambiguities with hightone roots (assuming rejection of the ambiguous practice of writing choti he for low-tone short vowels associated with de-aspiration, see 3.2.2.2). This is because both letters accurately represent the pre-vocalic location of lexical L (whereas choti he represents post-vocalic lexical $\mathrm{L}$ in high-tone words, provided it is consistently written after any explicit vowel). Therefore, since both representations rightly represent lexical L unambiguously and enjoy current use for large numbers of other Gojri words (assuming validation of the iconic representation for low tones resulting from de-aspiration), the 
spelling of uniquely indigenous words like those in (67) must be determined with reference to other criteria.

Two possible solutions are (1) to simply spell all low-tone words of this type with choti he, or (2) to spell with do chashmi he all such Gojri words for which transparent Urdu cognates are not found in modern Urdu dictionaries. Either solution is preferable to subjectively determining the spelling of each word on a case-by-case basis. The first solution may be preferable from the standpoint of maintaining constant word images between Gojri and Urdu, but its adoption is somewhat complicated by the proliferation of spellings like مهارو /mà̀ro/ 'our' in the Gojri literature of Indian-administered Kashmir. ${ }^{4}$ The second solution would afford an overall representation of low tone that is more uniform within Gojri itself, especially for text material that utilizes fewer nonindigenous words (i.e. it would strengthen rather than dilute the association of do chashmi he with the low toneme). Testing of both spelling patterns with new readers is needed to determine which potential ambiguity poses the greater problem: (1) the confusion of such do chashmi he spellings with spellings of words featuring initial voiceless aspiration; or (2) the confusion of such choti he spellings with spellings of high-tone words, especially those involving stems ending in /ع́/ and a long-vowel suffix (e.g. كباu /káa / 'we say').

\subsubsection{Evaluation Summary}

The evaluation presented above obviously reflects my own conviction that a tone representation which 'joins' the dialects and maximizes ease of transfer between Gojri and Urdu is better than a representation that 'splits' the dialects and promotes unique Gojri spellings. I have extensively documented the claim that a consistent one-to-one mapping of grapheme to toneme is impossible for any representation that values compatibility 
with Urdu. A surface representation for Gojri must admit high functional loads (and conflicting functions) for the letters do chashmi he and choti he, while still failing to represent all of the contrastive surface phenomena (most notably, any level low tone preceding a low-rising tone in words like /pìge'āṛ / (/bìgī'āṛ̂) 'wolf’).

The documentation demonstrates, however, that Urdu-based conventions in use by some Gujar writers approximate a consistent representation of underlying lexical L. In this view, do chashmi he and choti he are allographs of lexical L, and their distributions are dictated by Urdu spelling patterns rather than by surface contrasts. Such Urdu-based spellings correctly indicate the interpretation of surface tones while maintaining consistency of word image within Gojri and between Gojri and Urdu.

The full range of Urdu-based conventions for the representation of Gojri tonal words is presented in summary form in Table 8 below. The forms included in Table 8 are representative of the broader spelling patterns which I believe are suitable for standardization. I have not included any of the exceptional spellings noted elsewhere above, for which only one or two examples exist in my present database. While all of the spellings in Table 8 are in use in some quarter, neither they nor the patterns they represent are applied consistently across-the-board.

It remains then for Gujar writers to decide together which conventions should be standardized, and which kinds of tonal words should be spelled according to each convention. The success of such decision-making will depend upon many factors, including broad-based participation (geographically and dialectically), the linguistic facts, and the testing of alternate solutions for representative tonal words like /'mà̀ro/ 'our' (مهارو vs.) (مهارو (مهارو). 
Table 8. Urdu-based Conventions for Representing Lexical L in Gojri

$$
\text { 1st } \sigma \text { stressed } \quad \text { 2nd } \sigma \text { stressed } \quad 3 r d \sigma \text { stressed }
$$

Pre-vocalic lexical L (corresponding to surface low tone) is represented by:

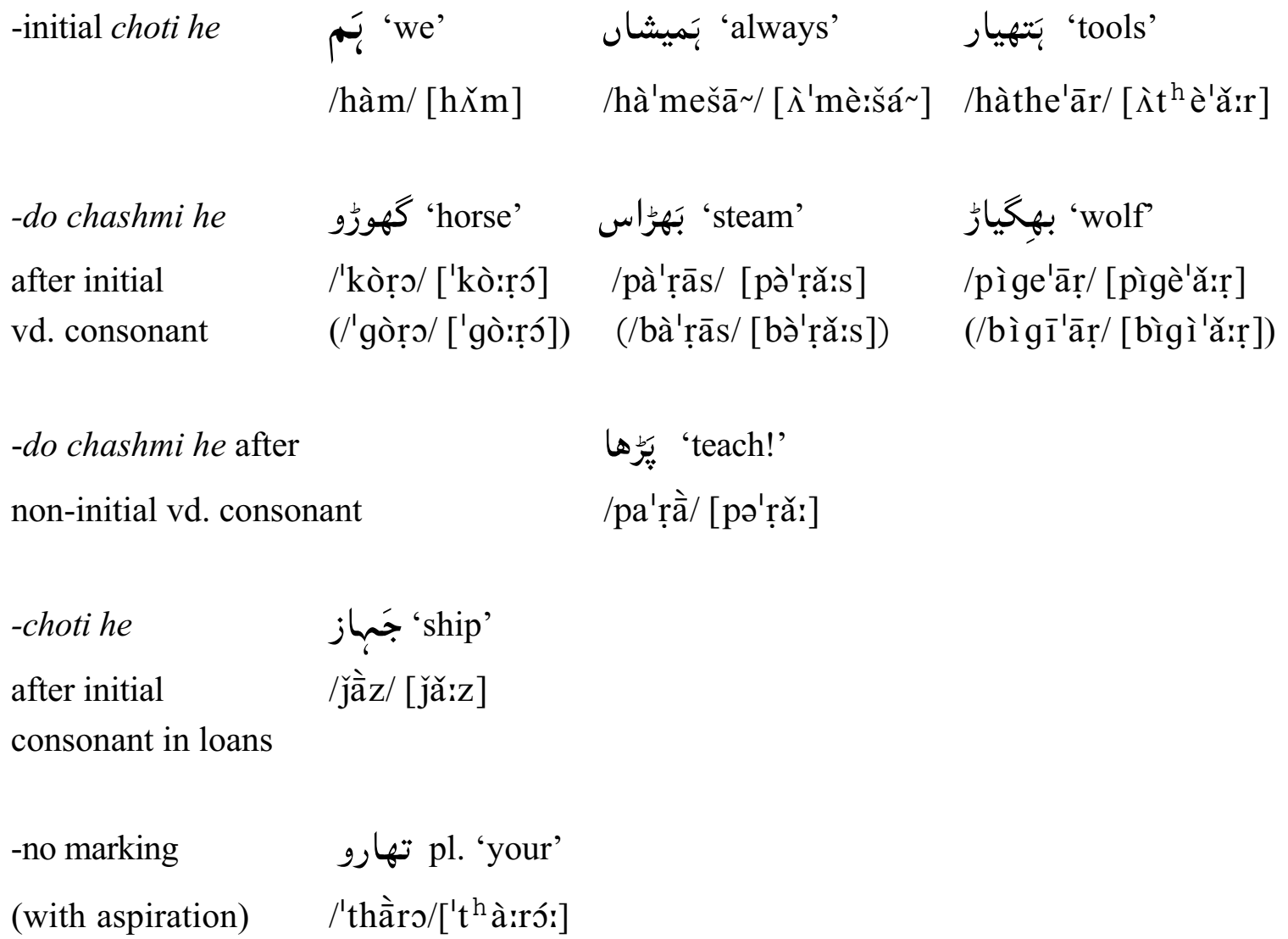

Post-vocalic lexical L (corresponding to surface high tone) is represented by:

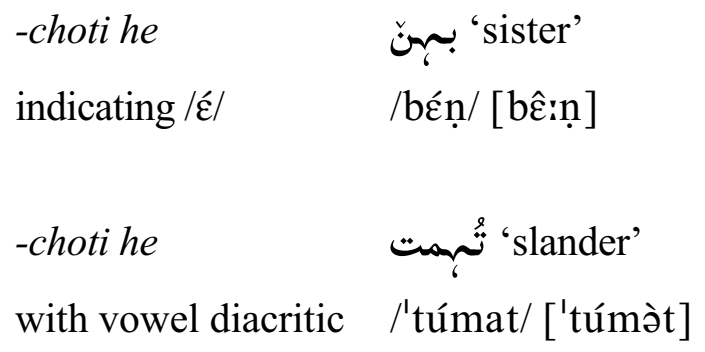


Table 8 cont.

-choti he

$$
\text { 'rat' }
$$

بادشاه 'king'

'unbeliever'

after explicit vowel /'čús/ ['čû:o]

/bād'šá/ [ba:d'šâ:] guma'rá [gumə'râ:]

(only loans for 2nd and 3rd columns)

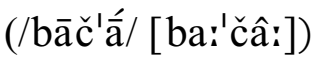

-do chashmi he

يَرْهُ 'read!'

after vd. consonant /pár 


\section{CHAPTER IV \\ COMPARATIVE GOJRI MORPHOSYNTAX}

What follows is only a preliminary statement of Gojri morphosyntax. I have necessarily limited myself to those topics which have a bearing on orthography and dialectal variation. I have attempted to exhaust the morphological phenomena in my data, while describing only those syntactic phenomena which are essential to understanding the morphological data and about which something unique can be said with respect to Gojri. Anyone having a basic familiarity with Indo-Aryan syntax should not be hindered by the resulting gaps in my analysis. Throughout I have utilized Masica's (1991) labels and analytic categories to simplify cross-linguistic comparison. I have made no attempt, however, to reconcile my analysis with that of Sharma for Punch-Rajauri Gojri (1982), although I do point out descriptive differences involving the shape of the morphemes themselves.

4.1 Noun-Phrase Constituents and Operations

4.1.1 The Structure of Nouns and Noun Phrases

\subsubsection{Marked and Unmarked Nouns}

From the perspective of their morphological structure, two subclasses of nouns can be distinguished in Gojri. Some nouns bear an overt marker that encodes gender (masculine vs. feminine), number (singular vs. plural), and case (nominative vs. general oblique vs. general locative). Here, following common practice in Indo-Aryan linguistics, such nouns are called 'marked'. 
Other nouns do not bear an overt marker for these categories. Such nouns are called 'unmarked'. (The oblique plural marker $/ \overline{\mathbf{a}} \sim /$ does not participate in this scheme of things. It attaches to both marked and unmarked nouns. The same is true for the vocative case marker in most of its forms.)

The stems of marked nouns are 'bound' elements in the sense that they cannot occur on their own, without the inflectional marker. The structure of marked nouns can be described as follows:

$$
\text { STEM - INFL1 - (INFL2) }
$$

INFL1 is the obligatory marker for gender, number, and case. INFL2 is a slot for an additional inflectional marker. This slot can be occupied by the oblique plural marker $/-\overline{\mathrm{a}} \sim /$ and by most forms of the vocative case marker. For example, consider the suffixes in (70):
$(70) \mathrm{E}$
$\begin{array}{ll}0 & \text { mer-e-ā } \\ \text { VOC } & \text { 1s.GEN-M.SG-VOC.M.SG }\end{array}$
lāyk bač-e-ā
'Oh my smart [boy] child!'
smart child-M.SG-VOC.M.SG

The structure of unmarked nouns is shown in (71):

$$
\text { STEM - (INFL2) }
$$

As stated above, unmarked nouns do not take the gender-number-case markers that occur in the INFL1 slot of marked nouns. However, unmarked nouns do combine with the INFL2 type of suffixes. For example consider the attachment of the oblique plural marker $/ \overline{\mathbf{a}} \sim /$ to the unmarked noun /rič/ 'bear' in (72):

$$
\text { rič-ā (nā) '(to) [the] bears' }
$$


In addition to taking the oblique plural marker $/-\overline{\mathrm{a}} \sim /$ and vocative case markers, certain stems of this class of nouns can also take an ablative case marker.

The stems of nouns from both categories may be further analyzed into roots and derivational suffixes. The reader interested in Gojri derivational morphology should refer to Sharma (1982), as I have not attempted any description of that topic here.

\subsubsection{The Noun Phrase}

The basic structure of the Gojri noun phrase is not distinct from that described by Masica for Indo-Aryan generally (1991:373). The noun is the right-most element in the phrase, with optional modifiers occurring to the left. While the order of these modifiers is not rigid, it may be generalized as follows:

$$
(\text { Gen P) / (Dem) (Quant) }(\text { Adj P)* (Gen P) + N }
$$

(The asterisk (*) indicates that more than one such constituent may occur in the specified location.)

That is, a noun phrase consists of a noun, preceded by an optional genitive phrase, one or more optional adjective phrases, an optional quantifier, and an optional demonstrative or genitive phrase. A genitive phrase consists of another noun and the genitive postposition /k-/ 'of', and may indicate possession (e.g. /mumtāz k̄̄/ 'Mumtaz's [feminine noun]') or quality (e.g. /maka $\overline{1} \mathrm{k} \overline{\mathrm{l}} /$ 'of corn'). An adjective phrase usually consists of an adjective, optionally preceded by an adverb of degree, e.g. /muč lāyk/ 'very intelligent'. The relative order of these constituents is shown in examples (74)-(76):

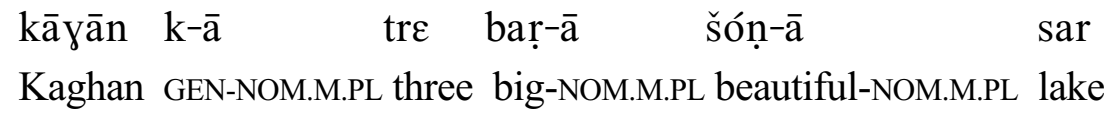
'Kaghan's three very beautiful lakes' 
(75)

wé do lam-ā kāblī jaṇ-ā

3pl.DIST.NOM.M two long-NOM.M.PL Afghani man-NOM.M.PL

'those two tall Afghani men'

(76)

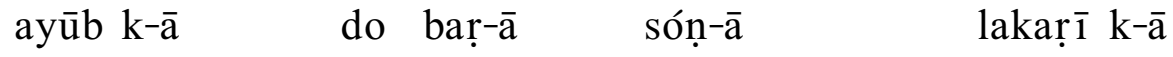

Ayub GEN-NOM.M.PL two big-NOM.M.PL beautiful-NOM.M.PL wood GEN-F.S

sandūk

chest

'Ayub's two very beautiful wooden chests'

Noun phrases which are more complex may include a relative clause: ${ }^{1}$

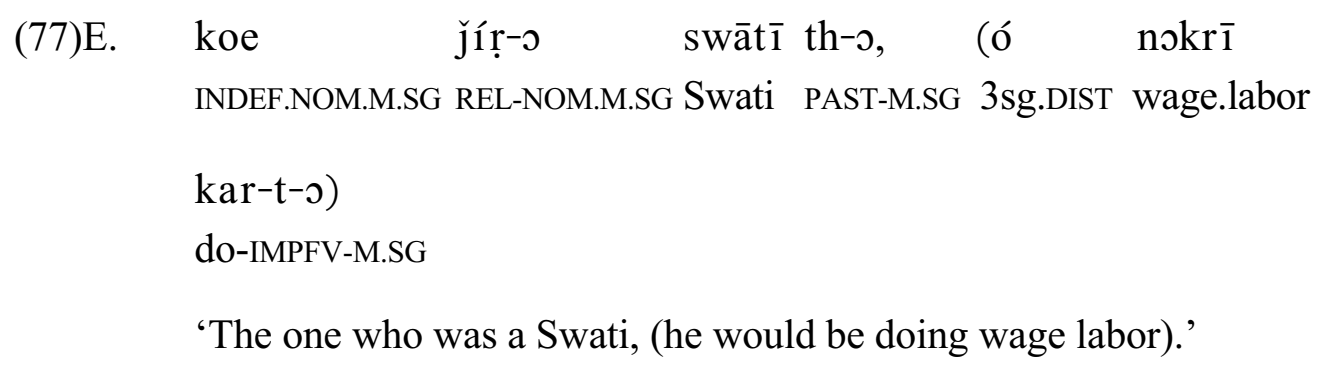

(78)W. ǰír REL-OBL.M.SG man-OBL.M.SG AG 1s.GEN-F 3sg.PROX.NOM.F box-F open-PERF-F

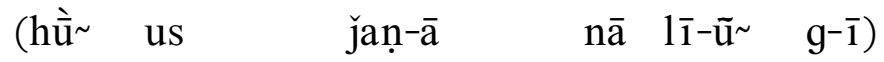

1s.NOM 3sg.DIST.OBL man-OBL.M.SG DAT take-1s FUT-F

'Whichever man opens this box of mine, (that man I will take).'

\subsubsection{Gender and Number}

Unmarked nouns have inherent gender, while their number in a given context will be coded elsewhere in the noun phrase. Marked nouns are inflected to distinguish masculine from feminine and plural from singular (the latter not in all instances) within a single suffix. Table 9 shows the inventory of these gender-number agreement suffixes: 
Table 9. Gender-Number Agreement Suffixes

\begin{tabular}{|c|c|c|}
\hline & Eastern & Western \\
\hline m.sg. & -0 & -0 \\
\hline m.pl. & $-\bar{a}$ & $-\bar{a}$ \\
\hline f.sg. & $-\overline{1}$ & $-\overline{1}$ \\
\hline f.pl. & $-\overline{1} \sim$ & $-\overline{1}$ \\
\hline
\end{tabular}

Masica uses the term 'adjectival concord' (AC) (1991:260) for suffixes of this type. In addition to marking nouns and adjectives, these AC suffixes occur widely within the verb phrase. Within the noun phrase these suffixes denote unmarked or nominative case.

Note that feminine singular and feminine plural are collapsed in the Western dialect. Since singular and plural number are also often collapsed in the verbal morphology of this dialect, number can only be distinguished for feminine nouns by means of a quantifier, by context, or by the number of a pronoun. The distinction between feminine singular and feminine plural is maintained in the Eastern dialect only on marked nouns (optionally and normally omitted in nominative if clear from a quantifier or pronoun), the relative pronoun, verbs, and auxiliaries. Adjectives, the genitive postposition, and other modifiers in the noun phrase take the feminine singular suffix for agreement with feminine plural nouns. Compare the Eastern and Western sentences in (79), noting the distribution of the feminine plural suffix $/ \overline{1} \sim /$ :

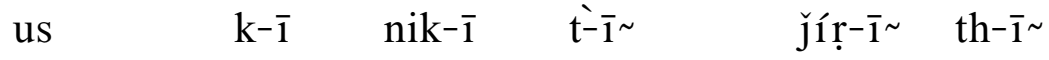

$$
\begin{aligned}
& \text { 3sg.DIST.OBL GEN-F.SG small-F.SG daughter-F.PL REL-F.PL PAST-F.PL }
\end{aligned}
$$

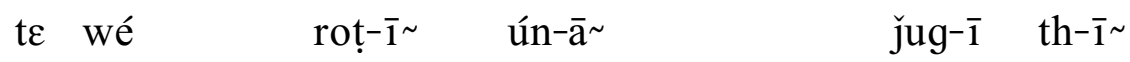

$$
\begin{aligned}
& \text { and 3pl.DIST.NOM bread-F.PL 3pl/HON.DIST.OBL-PL.OBL for-F.SG PAST-F.PL } \\
& \text { 'His little daughters that were, those breads were for them.' }
\end{aligned}
$$




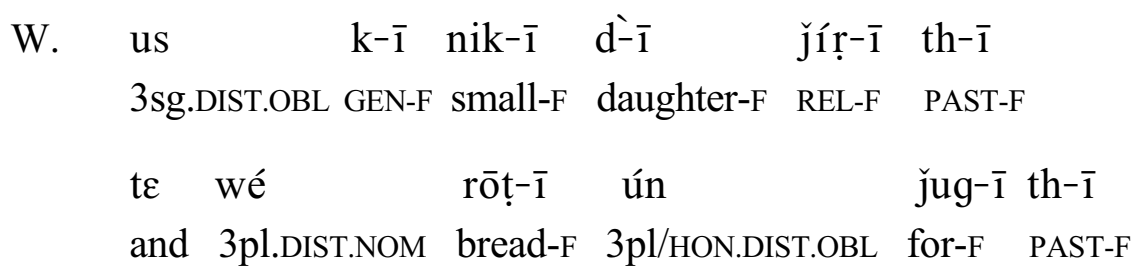

'His little daughters that were, those breads were for them.'

\subsubsection{Case and Postpositions}

Case relations in Gojri are encoded by means of three inflectional categories, representing three degrees of proximity to the noun stem. Masica organizes these categories as follows for Indo-Aryan languages: Layer I, consisting of suffixes; Layer II, consisting of morphemes whose attachment is mediated by a Layer I suffix; and Layer III, consisting of morphemes mediated by a Layer II element (1991:231-234). Nominative or 'direct' case is unmarked in Gojri; stems bearing adjectival concord function as subject in a wide variety of constructions and as 'patient' in ergative constructions.

\subsubsection{Layer I: Case-Marking Suffixes}

Most of the case-marking suffixes occur in the INFL1 slot of the Gojri noun (and therefore do not occur on unmarked nouns), while some of them occur in the INFL2 slot.

$/-\bar{a} /$ oblique masculine singular: attaches in the INFL1 slot to indicate that a postposition further specifying case will follow a marked masculine singular noun. It cannot occur without a following postposition.

$/-\overline{\mathbf{a}} \sim /$ oblique plural: attaches in the INFL2 slot to indicate that a postposition further specifying case will follow a plural noun. It attaches after feminine AC suffixes on marked nouns, but deletes the $\mathrm{AC}$ vowel $/ \overline{\mathrm{a}} /$ when attaching to a marked masculine plural. When affixed to an unmarked noun, this suffix may be the only morphological indication of plurality. In the Eastern dialect only, other constituents of the noun phrase, 
including numerals and possessive adjectives, normally take this oblique plural suffix to show agreement with a head noun so marked. It cannot occur without a following postposition.

/-E/ locative singular: attaches in the INFL1 slot of marked masculine singular inanimate nouns and to the stems of various possessive adjectives, postpositions, and adverbs to indicate abstract location. (Location is expressed for other types of nouns by means of postpositions such as /mā/ 'in'.) Nouns and postpositions which have nothing to do with locative or temporal notions cannot be so marked.

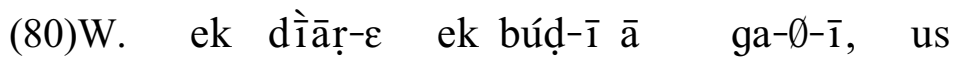

one day-LOC one old-F come go-PERF-F 3sg.DIST.OBL

ḍ̀n- $\overline{1} \quad \mathrm{k}-\varepsilon \quad$ der- $\varepsilon$.

woman-F GEN-LOC home-LOC

'One day an old woman came to that woman's home.'

/- $\varepsilon^{\sim} /$ locative plural: attaches in the INFL1 slot of inanimate marked masculine plural nouns to indicate abstract location. It may also attach to plural possessive adjectives and to the plural demonstrative stems /ín-/ and /ún-/. This morpheme occurs only in the Eastern dialect, and Sharma (1982) does not report it for Punch-Rajauri Gojri. Unlike the locative singular it cannot occur with the genitive postposition $\left(* / \mathrm{ke}^{\sim} /\right)$.
hùu $\quad$ thà̀r- $\varepsilon^{\sim}$
der- $\quad$ čal- $\overline{\mathrm{u}}^{\sim} \mathrm{k}-\mathrm{\jmath}$
1s.NOM 2pl/HON.OBL-LOC.PL home-LOC.PL go-1sg FUT-M.SG.NOM
'I will go to your homes.'

/- $\overline{\mathbf{u}} /$ ablative case: attaches in the INFL2 slot of select unmarked singular nouns to form adverbs indicating abstract point of origin: 


$$
\begin{array}{ll}
\operatorname{sir}-\bar{u} & \text { 'completely' (lit. 'from the head') } \\
\text { munḍ- } \bar{u} & \text { 'from the beginning' (lit. 'from the trunk') }
\end{array}
$$

Eastern speakers from the Muzaffarabad area have the variant $/-\overline{\mathrm{u}} \sim /$ in their speech, as do speakers of the Punch-Rajauri dialect (Sharma 1982:92). Some Western speakers have the variant $/-\mathrm{O}^{\sim} /$ in their speech.

$/-\bar{a} /$ vocative masculine singular: this and other vocative case suffixes mark the addressee. The vocative masculine singular suffix is phonetically identical to the oblique masculine singular, but unlike the oblique, it can attach to unmarked nouns and cannot be followed by a postposition. On marked masculine nouns and modifiers in the Eastern dialect, the attachment of this suffix in the INFL2 slot changes the masculine singular AC marker in the INFL1 slot from /- - / to /-e/ as shown in (83).

$$
\text { mers }+\bar{a}>\text { mereā }
$$

It attaches in the INFL2 slot of all unmarked masculine nouns, but does not attach to unmarked modifiers. Note the marking on the marked adjective /nik-/ 'little' and the unmarked noun /pūt/ 'son' in (84)a. Note the marking on the marked noun /bač-/ 'child' and the lack of marking on the unmarked adjective /lāyk/ 'smart' in (84)b.
(84)E.a. $\quad$ mer-e-̄a
nik-e-ā
pūt-ā
VOC 1sg.GEN-M.SG-VOC.M.SG
little-M.SG-VOC.M.SG son-VOC.M.SG
'Oh my little son!'
b. ग mer-e- $\bar{a}$
lāyk bač-e-ā
VOC 1sg.GEN-M.SG-VOC.M.SG smart child-M.SG-VOC.M.SG
'Oh my smart [boy] child!' 
The change of the AC marker from /-o/ to /-e/ does not apply when the addressee is senior to the speaker and denoted by a marked noun such as /čāčs/ 'paternal uncle', /kāko/ 'paternal uncle', or /bābo/ 'old man.' In these cases in the Eastern dialect, and for all occurrences of this suffix in the Western dialect, the suffix attaches in the INFL1 slot, replacing the $\mathrm{AC}$ vowel rather than changing it:
mer-e-ā
$\mathrm{kāk}-\bar{a}$
VOC 1sg.GEN-M.SG-VOC.M.SG paternal.uncle-VOC.M.SG
'Oh my uncle!'

W. $\quad$ mer- $\overline{\mathrm{a}} \quad \mathrm{k} \overline{\mathrm{a}} \mathrm{k}-\overline{\mathrm{a}}$

VOC 1sg.VOC.M.SG paternal.uncle-VOC.M.SG

'Oh my uncle!'

The form $/ \mathrm{k} \overline{\mathrm{a}} \mathrm{k}-\mathrm{e}-\overline{\mathrm{a}} /$ is possible in the Eastern dialect but normally reserved for goodnatured teasing, as it does not convey appropriate respect (cf. Sharma 1982:88).

/-e/ vocative feminine singular (Eastern only): attaches in the INFL2 slot of marked feminine nouns and associated marked modifiers, but may not attach to unmarked nouns and modifiers:
(86)E.a. $\quad$ mer- $\overline{1}-\mathrm{e}$
nik-1-e
béṇ
VOC 1sg.GEN-F.SG-VOC.F.SG little-F.SG-VOC.F.SG sister
'Oh my little sister!'
b. o mer-ī-e lāyk beṭ-ī-e
VOC 1 sg.GEN-F.SG-VOC.F.SG smart girl-F.SG-VOC.F.SG
'Oh my smart girl!'
c. ašrif $\mathrm{k}-\overline{\mathrm{i}}-\mathrm{e} \quad \mathrm{t}-\overline{\mathrm{i}}-\mathrm{e}$
Ashrif GEN-F.SG-VOC.F.SG daughter-F.SG-VOC.F.SG
'Daughter of Ashrif!' 
In the Western dialect, the vocative is unmarked for all feminine singular nouns and associated modifiers:
(87)W. $\quad 0 \quad$ mer- $\overline{1} \quad \mathrm{~d}-\overline{1}$
VOC 1sg.GEN-F daughter-F
'Oh my daughter!'

$/-\mathrm{J} /(/-\mathrm{\rho} /)$ vocative plural: attaches to the stem of unmarked nouns and after the AC suffix on marked feminine nouns and modifiers. Its Eastern form is identical in shape to the vocative interjection /o/ 'Oh!' In (88), note its attachment to the marked modifiers /mer-/ 'my' and /nik-/ 'little', and to the marked noun /tìi / (/dì /) 'daughter.'
(88)E.

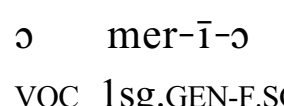
nik-1̄-o
$\mathrm{t} \overline{-} \overline{1}-0$
VOC 1sg.GEN-F.SG-VOC.PL little-F.SG-VOC.PL daughter-F.SG-VOC.PL
'Oh my little daughters!'

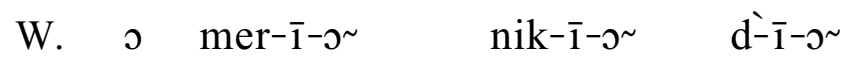 VOC 1sg.GEN-F-VOC.PL little-F-VOC.PL daughter-F.SG-VOC.PL
'Oh my little daughters!'

In the Eastern dialect it attaches to marked masculine nouns and modifiers after the AC suffix, changing the $\mathrm{AC}$ vowel from $/ \overline{\mathrm{a}} /$ to /e/ as shown in (89):

(89)E. merā + o > meres

In the Western dialect it attaches directly to the stem of marked masculine nouns. The vocative plural does not attach to unmarked modifiers in the Eastern dialect, or to any modifiers in the Western dialect. Consider examples (90)-(91).
(90)E
0 mer-e-0
lāyk pūt-o
VOC 1sg.GEN-M.PL-VOC.PL smart son-VOC.PL
'Oh my smart sons!' 


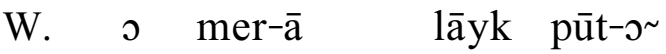

VOC 1sg.GEN-M.PL smart son-VOC.PL

'Oh my smart sons!'

(91)E. allā k-e-o band-e-s

Allah GEN-M.PL-VOC.PL man-M.PL-VOC.PL

'Men of Allah!'

W. allā k-ā band- $\jmath^{\sim}$

Allah GEN-M.PL man-VOC.PL

'Men of Allah!'

As noted for the vocative masculine singular, so here the plural suffix attaches directly to the stem of marked nouns denoting seniority:

(92)E. 0 mer-e-o kāk-o!

VOC 1sg.GEN-M.PL-VOC.PL paternal.uncle-VOC.PL

'Oh my uncles!'

W. $ว$ mer- $\bar{a} \quad$ kāk- $\jmath^{\sim}$

VOC 1sg.GEN-M.PL paternal.uncle-VOC.PL

'Oh my uncles!'

\section{$\underline{\text { Nominal Paradigms }}$}

Tables 10-12 present the regular inflections for marked animate nouns, marked inanimate nouns, and unmarked animate nouns, respectively; summarizing the distributions and attachments of the Layer I suffixes. 
Table 10. Inflection of Marked Animate Nouns: /bač-/ 'child'

\begin{tabular}{|c|c|c|c|c|c|c|c|}
\hline & & Nom sg. & Nom pl. & Obl sg. & Obl pl. & Voc sg. & Voc pl. \\
\hline \multirow[t]{2}{*}{ masc. } & E & bačo & bačā & bačā & bačā $\sim$ & bačeā & bačeo \\
\hline & W & " & " & " & " & bačāà & bač̃ \\
\hline \multirow[t]{2}{*}{ fem. } & E & bač $\overline{1}$ & bačī & bačī & bačī $\sim \overline{\mathbf{a}} \sim$ & bačīe & bačīo \\
\hline & W & " & bač $\overline{1}$ & " & bačīa $\bar{a}$ & bač $\overline{1}$ & bačīo \\
\hline
\end{tabular}

Table 11. Inflection of Marked Inanimate Nouns: /dèàr-/ (/dìārr-/) 'day’ (Kashmir variant is /tèār r -)

\begin{tabular}{|c|c|c|c|c|c|c|c|}
\hline & & Nom sg. & Nom pl. & Obl sg. & Obl pl. & Loc sg. & Loc pl. \\
\hline \multirow[t]{2}{*}{ masc. } & E & dèāạ̣ & dèāṛāa & dèāṛā & dèārāā & dèāṛ & dèāṛ $\varepsilon^{\sim}$ \\
\hline & W & dìāạo & dì̄āṛā & dìāṛā & dì̄āṛā & dìāạe & -------- \\
\hline \multirow[t]{2}{*}{ fem. } & $\mathrm{E}$ & dèāṛ $\overline{1}$ & dèāṛ $\overline{1} \sim$ & dèāṛ̂̄ & dèāṛ $\overline{1} \sim \overline{\mathrm{a}} \sim$ & ------- & -------- \\
\hline & $\mathrm{W}$ & dìārạ $\overline{1}$ & dì̄āṝ & dìāṝī & dì̄ârị $\bar{a} \bar{a}^{\sim}$ & --- & --- \\
\hline
\end{tabular}

Table 12. Inflection of Unmarked Animate Nouns: /pūt/ 'son', /béṇ/ 'sister'

\begin{tabular}{|c|c|c|c|c|c|c|c|}
\hline & & Nom sg. & Nom pl. & Obl sg. & Obl pl. & Voc sg. & Voc pl. \\
\hline \multirow[t]{2}{*}{ masc. } & E & pūt & pūt & pūt & pūtā & pūtā & pūto \\
\hline & W & $"$ & $"$ & $"$ & $"$ & pūt & pūto \\
\hline \multirow[t]{2}{*}{ fem. } & E & bén & bén & bén & béṇā̃ & bén & béṇo \\
\hline & W & " & $"$ & " & " & $"$ & béņ̣ \\
\hline
\end{tabular}

Unmarked inanimate nouns are inflected identically to those in Table 12 , but only for nominative and oblique cases as they cannot take vocative suffixes. 


\subsubsection{Layer II: Postpositions Mediated by Oblique Case}

\subsection{Primary or Case-Marking Postpositions}

Case-marking postpositions follow oblique-case nouns and pronouns.

/ne/ agentive case: marks the agent of an ergative construction. In addition to the marking of agents with /ne/, ergative constructions in Gojri feature the perfective 'participle' of a transitive verb (see 4.2.1.1), the nominative agreement ( AC) of which is always with the grammatical object rather than with the agent/subject:

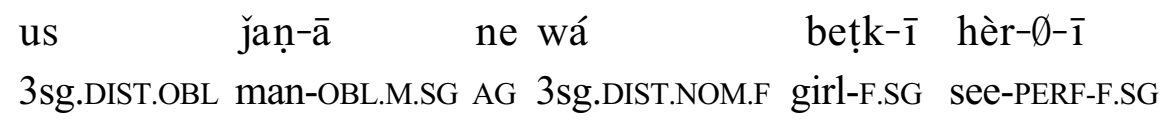

'That man saw the girl.'

(94)W.

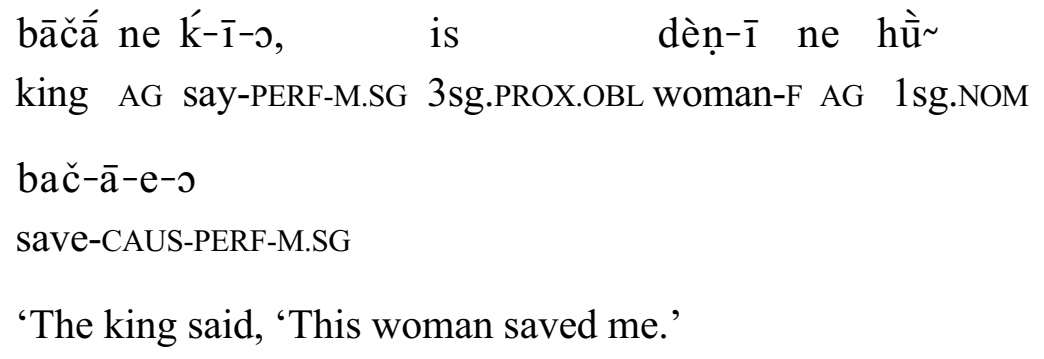

The most common use of /ne/ in discourse is with verbs of speaking like that in the first clause of (94). In such contexts where there is no expressed object, the agreement of the perfective form of the verb defaults to masculine singular.

In constructions where an indirect object is marked with dative case, /ne/ may mark the subject. Compare (95) with (96) and (97):
(95)E.
jawed nā pes-ā
de-n-ā
$h \dot{\varepsilon}^{\sim}$
Javed DAT money-NOM.M.PL give-INF-NOM.M.PL 3pl.PRES
'Javed needs to give money.' 
(96)E. jawed ne ašrif nā pes-ā de-ṇ-āa hغे Javed AG Ashrif DAT money-NOM.M.PL give-INF-NOM.M.PL 3pl.PRES 'Javed needs to give Ashrif money.'

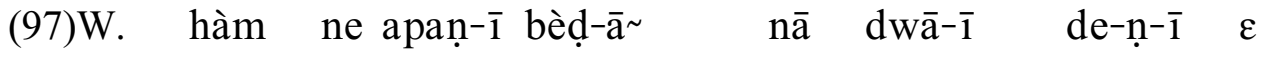
1p.NOM AG REFL-F sheep-OBL.PL DAT medicine-F give-INF-F PRES 'We need to give medicine to our sheep.'

The agentive postposition is reduced to $/ \mathcal{E}^{\sim} /$ or $/ \mathrm{e}^{\sim} /$ in certain pronominal forms, particularly in the Western dialect (see 4.1.4).

/te/ ablative case: most commonly marks source or origin (cf. English 'from') as in (98), and the undergoer of verbs of asking as in (99):

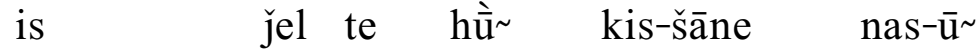

$$
\begin{aligned}
& \text { 3sg.PROX.OBL jail from 1sg.NOM INDEF.OBL-way run.away-1sg } \\
& \text { 'How shall I escape from this jail?' }
\end{aligned}
$$

(99)E. us ne nikaṛ-ī te pučh-e-o

3sg.DIST.OBL AG smallest-F.SG from ask-PERF-M.SG

'He asked the smallest [girl].'

It may have an instrumental sense, as in (100):

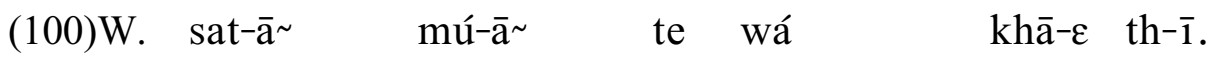
seven-OBL.PL mouth-OBL.PL from 3sg.DIST.NOM.F eat-2/3 PAST-F

'She ate with seven mouths.'

It may also indicate the agent in certain passive constructions (cf. English 'by'):

$$
\begin{array}{llll}
\text { wé } & \text { us } & \text { te } & \text { xuš hò-e-ā } \\
\text { 3pl.DIST.NOM } & \text { 3sg.DIST.OBL from happy be-PERF-M.PL }
\end{array}
$$

'They were gladdened by him.' 
/te/ is also used in comparatives (cf. English 'than'):

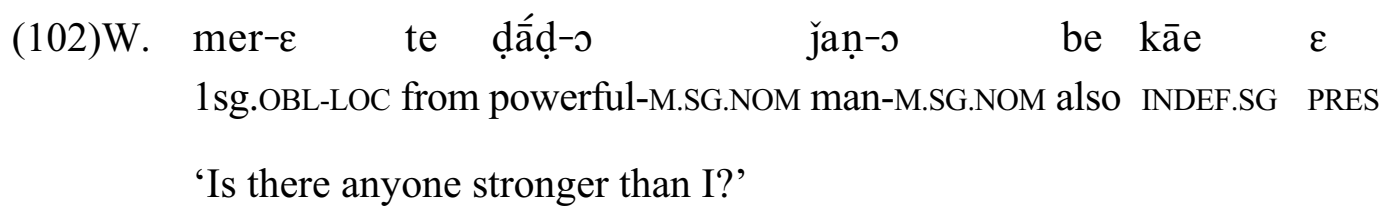

The Western sentence in (102) shows /te/ following locative case, as it may follow either oblique or locative case in that dialect. In Eastern it may occur only with oblique case.

Dr. Sabir Afaqi tells me that the variant $/ \mathrm{t} \overline{\mathrm{u}} \sim /$ is in his own speech (recall the ablative suffix variant $/-\overline{\mathrm{u}} \sim /$ ) and that $/$ te $/$ is used in other parts of Kashmir. Sharma reports the forms $/ \mathrm{d} \overline{\mathrm{u}} \sim /$ and $/ \mathrm{tu} \sim /$ for Punch-Rajauri Gojri (1982:192). The Kunhari Muhajar Bakarwals from whom I elicited the word list in Appendix B have the variant /de/.

/k-/ genitive case: normally indicates that there is a relationship between two nominal elements, particularly one of association or possession (cf. English 'of'):

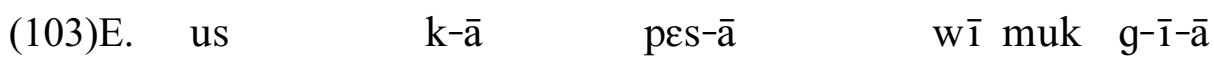

3sg.DIST.OBL GEN-M.PL.NOM money-M.PL.NOM also finish go-PERF-M.PL.NOM 'His money ran out too.'

(104)W. yó kāk-āar k-o gòn-o 3sg.PROX.NOM.M paternal.uncle-OBL.M.SG GEN-NOM.M.SG horse-NOM.M.SG PRES 'This is Uncle's horse.'

Like other marked nouns and modifiers, the genitive postposition takes the full complement of nominative AC endings (save the feminine plural in Western) along with whatever locative, oblique, and vocative suffixes are allowed for marked words in a given dialect. When occurring in the nominative with a single noun, it indicates reference (akin to the English 'concerning', 'about', 'with respect to'): 

(105)W. us-e de k-o ná ḱ k-̄os, 3sg.DIST.OBL-AG giant GEN-NOM.M.SG NEG say-PERF-M.SG
'He didn't speak about the giant.'

Sharma reports $/ \mathrm{g}-/$ as the genitive postposition for Punch-Rajauri (1982:121). This form is sometimes heard following nasals in Pakistan, particularly in Western varieties (see 2.5.5). In some Western varieties it also occurs in contexts like /lakaṝ go (sandūk)/ 'wooden (chest)' (lit. 'chest of wood'). Further research is needed to establish the distribution of this variant.

/nā/ dative case: marks direct and indirect objects as in (106) and (107), respectively, the direction ('to') or purpose of ('for') the verbal action as in (108) and (109), respectively, and the experiencer subject in any 'dative subject' construction (Masica 1991:346) like that in (110):

(106)W. tam ke kar-e rič nā

2pl.NOM what do-2/3 bear DAT

'What shall you do to the bear?'

(107)W. hàm nā roz $\overline{1}$ xudā $d \overline{1}-\varepsilon$

1p. DAT daily.wage God give-2/3

'God gives us [our] livelihood.'

(108)E. pà̀y jā r-é-o bạ̣ nā

brother go stay-PERF-M.SG forest DAT

'The brother left for the forest.'

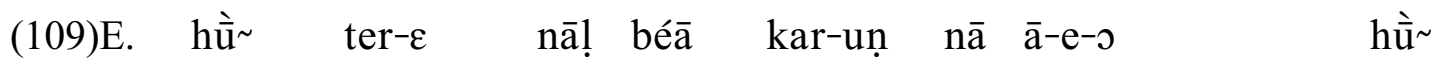
1sg.NOM 2sg.OBL-LOCwith marriage do-INF.OBL DAT come-PERF-M.SG.NOM 1sg.PRES 'I have come to marry you.' 
(110)E. bādšá nā lér čár- Ø-̄în

king DAT anger climb-PERF-F.SG

'The king got angry.' (lit. 'Anger climbed the king.')

In the Western dialect, the dative postposition is reduced to $/ \overline{\bar{a}} \sim /$ in third person singular pronominal forms.

\subsection{Other Layer II Postpositions}

These postpositions occur with locative or oblique case. In Western there may be less precision about whether locative or oblique case is required for a given use of a postposition.

/dar/ (/tā/) showing directionality: specifies direction of the verbal action. It overlaps somewhat with the dative postposition /nā/ but is not used for experiencer constructions. The distributions of this postposition are not identical for both dialects. In Eastern it follows locative case:

(111)E. ter- $\varepsilon$ dar xat likh ke tor- $\overline{\mathrm{u}} \sim$

2sg.GEN-LOC toward letter write CP send-1sg

'Shall I write you a letter and send it?'

The Western variant follows oblique case:

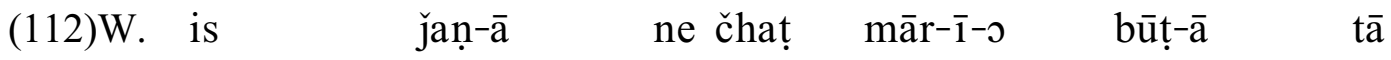
2sg.PROX.OBL man-OBL.M.SG AG grabbing hit-PERF-M.SG tree-OBL.M.SG toward nap-un tā catch-INF.OBL toward

'This man grabbed at the tree to catch hold of it.' 
/mā/ 'in': occurs with oblique case:

(113)W. wó

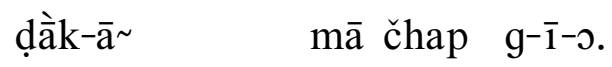

2sg.M.DIST.NOM mountain-PL.OBL in hide go-PERF-M.SG.NOM

'He hid in the mountains.'

/tak/ showing extent or limit - 'as far as, until': occurs with oblique case in adverbials of place and time:

$$
\begin{array}{lllll}
\text { wó } & \text { is } & \text { hath tak } & \text { sax } \overline{1} & \text { th-o } \\
\text { 3sg.DIST.NOM.M } & \text { 3sg.PROX.OBL hand until } & \text { generous } & \text { PAST-M.SG }
\end{array}
$$

'He was generous to this extent, ...'

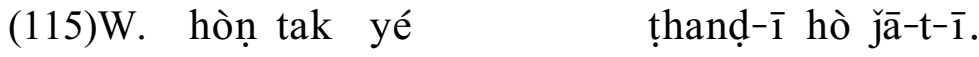

now until 3pl.PROX.NOM cold-F be go-IMPFV-F

'These would have cooled off by now.'

/tūṝi / (/tūṇ̄î) showing extent or limit - 'as far as, until': occurs with oblique case in adverbials of place and time:

(116)E. a jāà tūṝ min-nā xat nó mil-e-o

now until 1sg.OBL-DAT letter NEG meet-PERF-M.SG

'Until now I have not received a letter.'

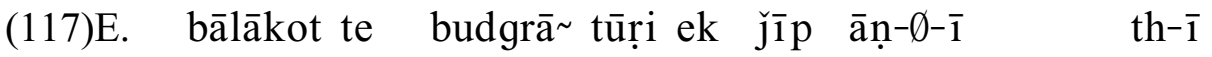

Balakot from Budgran until one jeep bring-PERF-F.SG PAST-F.SG

'[We] brought a jeep from Balakot to Budgran.'

/wāste/ showing benefaction or purpose -'for': occurs with oblique case, marking the indirect object or indicating purpose (a use in which it overlaps with with $/ \mathrm{n} \overline{\mathrm{a}} /$ and /dar/ (/tāa)): 


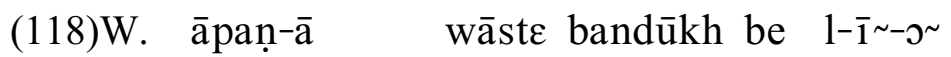

REFL-OBL.M.SG for gun also take-FUT.IMP-2pl

'Choose guns for yourselves.'

(119)E. is gal wāste me $\varepsilon^{\sim}$ yé čal-ā-e-āa

3sg.PROX.OBL word for 1sg.AG 3pl.PROX.NOM go-CAUS-PERF-M.PL.NOM

'[It was] for this matter [that] I sent these [people].'

/jug-/ showing benefaction -'for’: occurs with oblique case. Agreement is with head noun in Eastern, where it takes the full complement of AC endings minus the feminine plural.

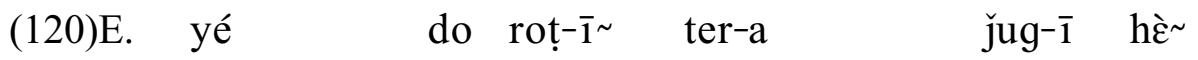

3pl.PROX.NOM two bread-F.PL 2sg.GEN-OBL.M.SG for-F.SG 3pl.PRES

'These two pieces of bread are for you.'

My Western-speaking research associate reports that in his dialect the feminine ending works for head nouns of both genders, but the masculine endings only work when the head noun is also masculine:

(121)W.a. gòr-o ter-āa jug $-\overline{1} \varepsilon$

horse-NOM.M.SG 2sg.GEN-OBL.M.SG for-F PRES

'The horse is for you.'

b. *yá čá ter-āa jug-o $\varepsilon$

3sg.PROX.NOM.F tea 2sg.GEN-OBL.M.SG for-NOM.M.SG PRES

*‘This tea is for you.' (ungrammatical)

/lāyk/: approximates /wāste/ in meaning. It occurs with locative case in the idiom shown in (122). 
(122)E. mer-e lāyk kāe xizmat hè

1sg.GEN-LOC from INDEF.M service $2 / 3$ sg.PRES

'Is there anything I can do for you?' (lit. 'From me is [there] any service?)

/samēt/ showing inclusion: occurs with oblique case:

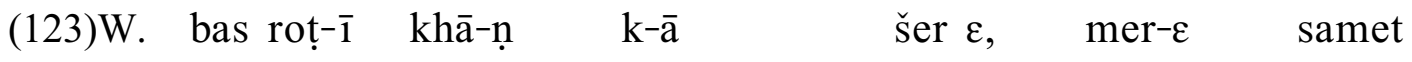
stop bread-F eat-INF.OBL GEN-M.PL.NOM lion PRES 1sg.GEN-LOC together '[They] are lions only of food-eating, myself included.'

\subsubsection{Layer III Postpositions}

This final category includes all remaining postpositions. These are optionally or necessarily mediated by the genitive /k-/ or ablative /te/ postpositions from Layer II. Most of the stems involved may also occur as adverbs, a use distinguished by placement in a position other than post-nominal together with the lack of a Layer II mediating postposition.

\subsection{Postpositions Mediated by the Genitive-Locative Postposition $/ \mathrm{k} \varepsilon /$}

Postpositions of this type occur optionally with the genitive postposition inflected for locative case, i.e. $/ \mathrm{k} \varepsilon /$ or with the locative form of a possessive adjective (see 4.1.4). With or without $/ \mathrm{k} \varepsilon /$, the modified noun must be in the oblique case. Those adverbs which are formed by adding the ablative suffix $/-\overline{\mathrm{u}} /$ to postpositions of this type cannot occur with $/ \mathrm{k} \varepsilon /$, but rather occur with an oblique-case noun phrase.

/nāḷ/ instrumental-sociative postposition (Masica 1991:235). Consider these examples:

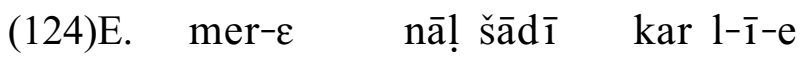
1sg.GEN-LOC with marriage do take-FUT.IMPV-2sg 'Marry me.' (more lit. 'Contract marriage with me.') 


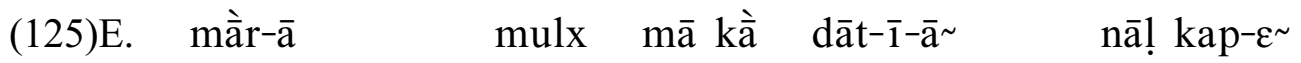
1pl.GEN-NOM.M.SG country in grass sickle-F.SG-OBL.PL with cut-3pl 'In our country grass is cut with sickles.'

With the ablative suffix it forms the adverb /naḷ $\bar{u} /$ which has an ablative-sociative sense:

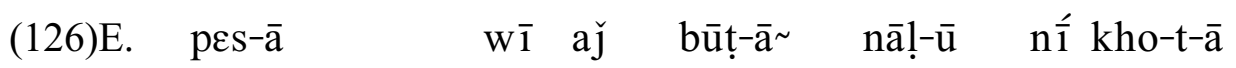
money-NOM.M.PL also today tree-OBL.PL with-ABL NEG pick-IMPFV-M.PL

'And another thing, today money isn't picked from trees.'

(127)W. wá mer-e nālē xapā $\varepsilon$

3sgg.DIST.NOM.F 1 sg.GEN-LOC with-ABL upset PRES

'She is upset with me.'

/bič/ 'in, into':

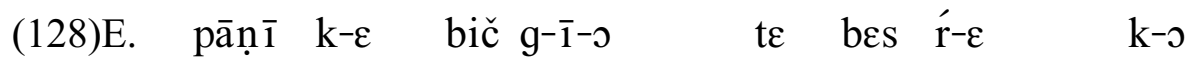
water GEN-LOC in go-PERF-M.SG then sit stay-2/3sg FUT-M.SG

'When it goes into water it will sit down.'

With the ablative suffix it forms the adverb /bičū/ 'from out of'.

/hèțh/ 'under':

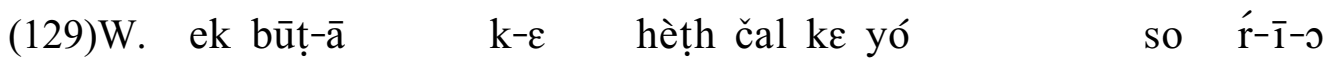
one tree-OBL.M.SG GEN-LOC under go CP 3sg.PROX.NOM.M sleep stay-PERF-M.SG 'Going under a tree he went to sleep.'

With the ablative suffix it forms the adverb /hèthhū/ 'from under'.

/kol!/ (/kole/) showing proximity or possession: occurs necessarily with / ke/ after unmarked nouns in the Eastern dialect (130), without $/ \mathrm{k} \varepsilon /$ after locative first and second person prounouns (131), and optionally with / ke/ after marked oblique nouns. 
(130)E. nokar hò-we mer-e kol servant be-2/3sg 1sg.GEN-LOC by

'I should have a servant.' (lit. 'A servant should be by me.')

The Western variant reflects addition of the locative case suffix /-ع/:

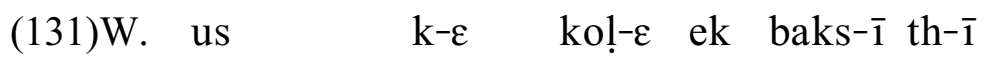

3sg.DIST.OBL GEN-LOC by-LOC one box-F PAST-F

'She had a little box.' (lit. 'By her was a little box.')

With the ablative suffix it forms the adverb /kolū/ ' from near'.

/andar/ 'inside of':

(132)E. ek mìn-ā ke andar andar xīr-o phut one month-OBL.M.SG GEN-LOC inside inside diamond-NOM.M.SG break jā- $\varepsilon \quad \mathrm{k}-\mathrm{o}$ go-2/3sg FUT-M.SG

'The diamond will break within one month.'

With the ablative suffix it forms the adverb /andrū/ 'from out of'.

/apar/ (/upar/) (/po/) 'on': The form /apar/ (/upar/) is used with or without /ke/, while an additional Western variant /po/ occurs only without $/ \mathrm{k} \varepsilon /$ :

(133)E. rấ apar laraz te saxt-ī bì path on trouble and hardship-F.SG also 'On the way there is trouble and also hardship.'

(134)W. is rá po čal

3sg.DIST.OBL path on go

'Walk on this path!' 
(135)E. ek angūṭh-1 th- $\overline{1}$ hàth $\mathrm{k}-\varepsilon$ apar

one ring-F.SG PAST-F.SG hand GEN-LOC on

'There was one ring on [her] hand.'

(136)W. gòr-ā $\quad \mathrm{k}-\varepsilon$ upar laḍ

horse-OBL.M.SG GEN-LOC on load

'Load [it] on the horse!'

In Eastern, /apar/ with the ablative suffix forms the adverb /aprū/ 'from off of'.

/age/ 'ahead of', 'before': consists of the root/ag-/ and the locative suffix /-ع/. It occurs optionally with $/ \mathrm{k} \varepsilon$ / in locative constructions or /te/ in directional constructions:

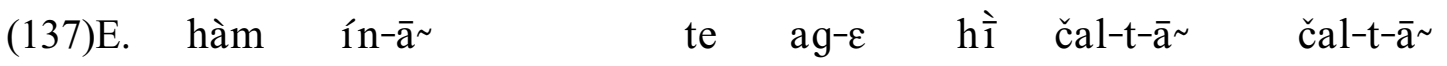

1sg.NOM 3pl.DIST.OBL-OBL.PL from ahead-LOC EMPH go-IMPFV-ADV go-IMPFV-ADV

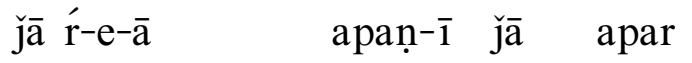

go stay-PERF-M.PL REFL-F.SG place on

'Way ahead of them we went on and went on - we went to our own place.'

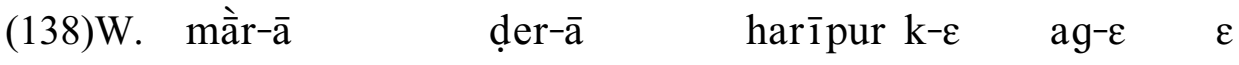

1pl.GEN-NOM.M.PL home-NOM.M.PL Haripur GEN-LOC ahead.of PRES

'Our households are beyond Haripur.'

/pičhe/ 'behind': consists of the root/pičh-/ and the locative suffix /-E/. It may occur

following $/ \mathrm{k} \varepsilon /$ or $/ \mathrm{te} /$ depending upon the context, or without any preceding postposition.

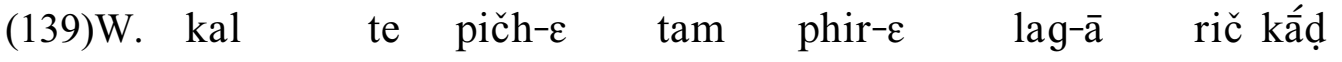
yesterday from behind-LOC 2pl.NOM wander-2/3 CONT-M.PL bear after

'Since yesterday you have been wandering around after the bear.' 
/sāmṇ̨/ (/sāmḷ ع/) 'across from': occurs necessarily with /ke/:

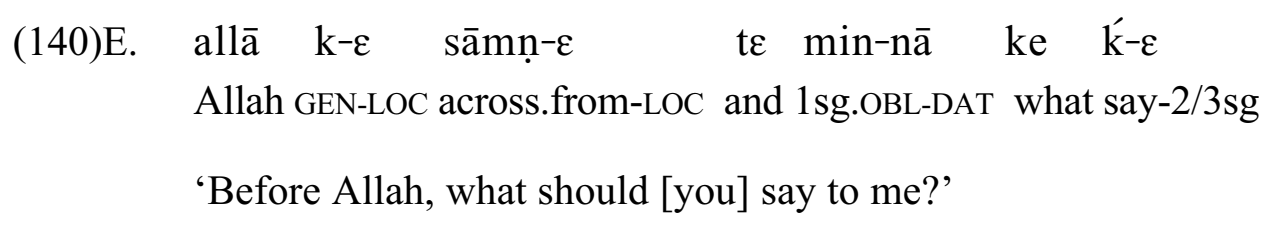

\subsection{Postpositions Mediated by the Ablative Postposition /te/}

Postpositions of this type occur necessarily with the ablative postposition /te/ after an oblique case noun or pronoun. These include /bấd/ 'after', /kấḍ/ 'after' (synonymous with /băd/), /pār/ 'across', /pélā $/$ 'before' (which when occurring without /te/ is an adverb rather than a postposition), and /swā/ 'without'.

Those adverbs which are formed by adding the ablative suffix $/-\overline{\mathrm{u}} /$ to postpositions of this type occur not with /te/, but with an oblique-case noun phrase. These include /kāḍū/ 'afterwards' and /pārū/ 'from across'.

\subsubsection{Pronouns and Demonstratives}

Tables 13-15 below contain the Gojri personal pronouns in their various inflections, of which the third person nominative forms in tables 14 and 15 also function as demonstratives. Indefinite and relative pronouns, along with their corresponding interrogative forms, are shown in tables 16-17. The reflexive pronoun is shown in Table 18.

For the purpose of highlighting variation, I have only shown ditto marks wherever a form in a paradigm is identical to the one directly above. Genitive forms are generally shown only with masculine singular AC suffixes, although all of the suffixation shown for the noun in tables 10 and 11 , save the the feminine plural suffix, is equally applicable. Similarly, oblique forms are generally shown only with the dative postposition $/ n \bar{a} /$, 
although the ablative postposition /te/ also occurs with the same set of forms (however, with /te/, the Western singular stems are identical to those shown for Eastern in Table 13; the distribution of other postpositions varies).

First and Second Person Pronouns

Table 13. First and Second Person Pronouns/Possessive Adjectives

\begin{tabular}{|c|c|c|c|c|c|}
\hline & & Nom & $\mathrm{Ag}$ & $\begin{array}{l}\text { Obl } \\
\text { w/Dat }\end{array}$ & $\begin{array}{l}\text { Gen } \\
\text { w/masc.sg. }\end{array}$ \\
\hline 1 sg. & $\mathrm{E}$ & hì $\sim$ & $m \varepsilon^{\sim}$ & minnā & mero \\
\hline & $\mathrm{W}$ & $"$ & $"$ & mannā & $"$ \\
\hline $1 \mathrm{pl}$. & & hàm & ham ne & hàm nā & màro \\
\hline $2 \mathrm{sg}$. & $\mathrm{E}$ & to $\sim$ & $\mathrm{t} \varepsilon^{\sim}$ & tinnā & tero \\
\hline & $\mathrm{W}$ & to & $"$ & tannā & $"$ \\
\hline $2 \mathrm{pl}$. & & tam & tam ne & tam nā & thàro \\
\hline
\end{tabular}

The 'genitive' forms in Table 13 are possessive adjectives in form and function, i.e. their inflection and distribution are identical to that for marked adjectives (cf. Masica 1991:251). Forms shown as fused to postpositions are those which only occur when there are no intervening words between the pronoun and postposition. The postposition is shown as a separate word wherever the shape of both morphemes remains unaltered by intervening words.

As noted in 2.5.3, the Eastern first and second person plural agentive and oblique/dative forms shown here contract when there is no intervening word:

(141) Contracted Eastern Agentive and Oblique/Dative Forms

$\begin{array}{lll}\text { Underlying Form } & \text { Pronunciation } & \text { Gloss } \\ \text { /hàm ne/ } & {[\text { hìmṇe: }]} & \text { 'we [did]' } \\ \text { /tam ne/ } & {[\mathrm{t} \Lambda \mathrm{mṇe:}]} & \text { 'you [did]' }\end{array}$




$\begin{array}{lll}\text { /hàm nā/ } & {[\text { hìmṇa: }]} & \text { 'to us' } \\ \text { /tam nā/l } & {[\text { tımṇa: }]} & \text { 'to you' }\end{array}$

In the Eastern dialect, second person plural pronouns and associated agreement in the verb phrase are used honorifically for singular referents. The Western variety spoken by the Allaiwal Muhajar Bakarwals does the same (see Appendix B, words 203-204), but the Allaiwal Bakarwal variety (my Western reference dialect) does not. This honorific device is reported as normative for addressing elders. However, I have only rarely heard children use it when speaking to their parents or grandparents. It is more commonly used by adults addressing persons of higher social rank, a practice which may be spreading under the influence of Hindko and Urdu.

$\underline{\text { Singular Demonstrative Pronouns }}$

Table 14. Singular Demonstrative Pronouns

\begin{tabular}{|l|l|l|l|l|l|}
\hline & $\begin{array}{l}\text { Nom } \\
\text { masc }\end{array}$ & $\begin{array}{l}\text { Nom } \\
\text { fem }\end{array}$ & $\begin{array}{l}\text { Obl } \\
\text { w/Ag }\end{array}$ & $\begin{array}{l}\text { Obl } \\
\text { w/Dat }\end{array}$ & $\begin{array}{l}\text { Obl } \\
\text { w/Gen }\end{array}$ \\
\hline 3sg.prox. & yó & yá & is ne & is nā & is ks \\
\hline 3sg.dist. & wó / ó & wá / ó & us ne & us nā & us ks \\
\hline
\end{tabular}

In the Western dialect, the third person agentive and dative forms of the oblique shown here normally contract when there is no intervening word:

(142) Contracted Western Oblique Forms: Agentive and Dative

$\begin{array}{lll}\text { underlying form } & \text { pronunciation } & \text { gloss } \\ \text { /is ne/ } & {\left[\text { is:e }^{\sim}\right]} & \text { 'he/she/this one [did]' } \\ \text { /us ne/ } & {\left[\text { us:e }^{\sim}\right]} & \text { 'he/she/that one [did]' } \\ \text { /is nā/l } & {\left[\text { isa: }^{\sim}\right]} & \text { 'to him/her/this one' } \\ \text { /us nā/ } & {\left[\text { usa: }^{\sim}\right]} & \text { 'to him/her/that one' }\end{array}$


The third singular distal variant /ó/ is used for both genders, and occurs unchanged with all case-marking postpositions when there is an intervening noun. For example, /ó (beṭkī) ne/ 'that (girl) [did]' is grammatical, but /*ó ne/ 'she [did]', is not. If there is no intervening noun, then the oblique form /us/ is required.

$\underline{\text { Plural Demonstrative Pronouns }}$

Table 15. Plural Demonstrative Pronouns

\begin{tabular}{|c|c|c|c|c|}
\hline & Nom & $\begin{array}{l}\text { Obl } \\
\text { w/Ag }\end{array}$ & $\begin{array}{l}\text { Obl } \\
\text { w/Dat }\end{array}$ & $\begin{array}{l}\text { Obl } \\
\text { w/Gen }\end{array}$ \\
\hline 3pl.prox. E & yé & ínā ne & ínā nā & ín ko \\
\hline variant $E$ & -------- & --------- & --------- & ínā ko \\
\hline W & $"$ & ín ne & ín nā & ín ko \\
\hline variant $W$ & --------- & --------- & --------- & íngo \\
\hline 3pl.dist. E & wé & únā ne & únā nā & ún $\mathrm{ko}$ \\
\hline variant $\mathrm{E}$ & --------- & ---------- & -------- & únā ko \\
\hline W & $"$ & ún ne & ún nā & ún ko \\
\hline variant $W$ & --------- & --------- & --------- & úngo \\
\hline
\end{tabular}

The high tone on the third oblique plural forms shown in this table is established on such contrasts as that between /ún ko (rang)/ 'their (color)' and/un ko (rang)/ '(color) of wool'.

The inter-dialectal and intra-dialectal variation shown in Table 15 consists entirely in the use or non-use of the oblique plural suffix $/-\overline{\mathrm{a}} \sim /$. The suffix does not occur in Western forms, and it is optional with the Eastern genitive forms (its non-use being slightly preferred). 
As stated in 2.5.5, the genitive postposition $/ \mathrm{k}^{-/}$becomes [ $\left.\mathrm{g}^{-}\right]$following any nasalized vowel or consonant in the speech of many Western dialect speakers:

$$
\begin{array}{ll}
\multicolumn{3}{l}{\text { Western voicing of the genitive postposition /k-/ following a nasal }} \\
\begin{array}{lll}
\text { underlying form } & \text { pronunciation } & \text { gloss } \\
\text { /ín ko/ } & \text { [íngo: }] & \text { 'of these' } \\
\text { /ún ko/ } & \text { [úngo: }] & \text { 'of them' }
\end{array}
\end{array}
$$

Third plural pronouns and associated agreement in the verb phrase may be used honorifically for singular referents, particularly for prophets and other Muslim noteworthies. The application of this honorific device is uneven in discourse, however, but its use may be on the rise under influence from other regional languages and Islamicization.

The extension /hòr/, which has grammaticalized from the adjective meaning 'additional' or 'other', is used with names to denote a larger group of people associated with the named person (cf. the use of the abbreviation 'et al.' in English), as in (144) and (145), or honorifically for singular proper nouns in the Eastern dialect as in (146):

(144)E. ašrif hòr-̄ā ne makay kap čhuṛ $\emptyset-\overline{1}$ Ashrif PL/HON-OBL.PL AG corn cut drop-PERF-F.SG

'Ashrif and the others cut the corn.'

(145)E. ikbāl hòr $\quad \mathrm{kad} \quad \overline{\mathrm{a}}-\mathrm{w} \varepsilon^{\sim} \quad \mathrm{k}-\overline{\mathrm{a}}$

Iqbal PL/HON when come-3pl FUT-M.PL

'When will Iqbal and everyone come?'

(146)E. ǰinā hòr- $\bar{a} \sim$ ne baṛ- $\overline{1}$ ménat $\mathrm{k}-\emptyset-\overline{1}$ Jinnah PL/HON-OBL.PL AG big-F.SG hard.work do-PERF-F.SG 'Jinnah worked very hard.' 
Indefinite Pronouns, with Corresponding Interrogative Pronouns

Table 16. Indefinite Pronouns, with Corresponding Interrogative Pronouns

\begin{tabular}{|ll|l|l|}
\hline & & Nom & Obl \\
\hline indefinite pl. & & kúj & kúj̄̄̃ \\
\hline indefinite masc.sg. & E & koe & kise \\
\hline indefinite masc.sg. & W & kāe & kāe \\
\hline indefinite fem.sg. & E & kāe & kise \\
\hline indefinite fem.sg. & W & kāe & kāe \\
\hline interrogatives: 'Who?' / 'What?' & kọn / ke & kis / káa \\
\hline
\end{tabular}

Inflectional distinctions observed for the Eastern dialect are collapsed in the Western dialect. The form $/ k \bar{a} \sim /$ is used for inanimate referents. The genitive phrase $/ k \bar{a} \sim$ (ko)/ 'what kind (of)?' is common in questions like (147):

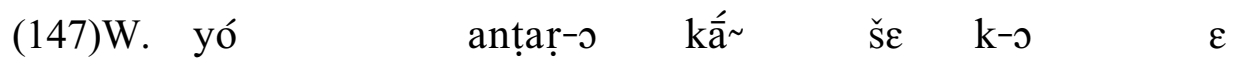

3sg.PROX.NOM.M egg-NOM.M.SG what-OBL thing GEN-NOM.M.SG PRES

'What kind of egg is this?'

$\underline{\text { Relative Pronouns, with Corresponding Interrogative Pronouns }}$

Table 17. Relative Pronouns, with Corresponding Interrogative Pronouns (unique Western forms are in parentheses)

\begin{tabular}{|c|c|c|c|c|c|c|}
\hline & $\begin{array}{l}\text { Nom } \\
\text { sg. }\end{array}$ & $\begin{array}{l}\text { Nom } \\
\text { pl. }\end{array}$ & Obl sg. & $\begin{array}{l}\text { Obl sg. } \\
\text { variant }\end{array}$ & Obl pl. & $\begin{array}{l}\text { Obl pl. } \\
\text { variant }\end{array}$ \\
\hline rel.masc. & júr ṛo & ǰíṛāà & ǰíṛā & jis & ǰírāa & $\begin{array}{l}\text { jin̄̄a } \\
\text { (jin) }\end{array}$ \\
\hline rel.fem. & ǰírị & 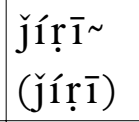 & ǰír & " & 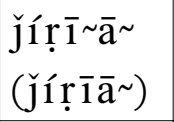 & " \\
\hline interr.masc. & kírọ & kíṛā & kírāā & kis & kírāa & $\begin{array}{l}\text { kinā } \\
\text { (kin) }\end{array}$ \\
\hline interr.fem. & kíṝ & $\begin{array}{l}\text { kíṝi } \\
\text { (kírịi) }\end{array}$ & kíṝ & " & $\begin{array}{l}\text { kíṛī } \bar{i} \bar{a}^{\sim} \\
\left(k i ́ r i \bar{a} \bar{a}^{\sim}\right)\end{array}$ & " \\
\hline
\end{tabular}


The stems /kír-/ and /ǰír-/ are not reported by Sharma. He reports /jo/ as the nominative relative pronoun for all genders and numbers along with the oblique variants

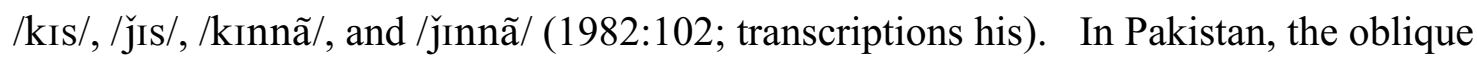
variants may be preferred wherever the relative pronoun occurs without another noun (cf. the same difference between English 'who?' and 'which?'); e.g. /kis nā/ 'to whom?' vs. /kírā lurā nā/ 'to which boy?'

\section{The Reflexive Pronoun /āp/}

Table 18. The Reflexive Pronoun /āp/

(unique Western forms not shown)

\begin{tabular}{|l|l|l|l|l|}
\hline Nom & $\begin{array}{l}\text { forms used } \\
\text { w/Ag }\end{array}$ & $\begin{array}{l}\text { Gen } \\
\text { Loc (w/Dat) }\end{array}$ & $\begin{array}{l}\text { Gen } \\
\text { w/Nom.masc.sg. }\end{array}$ & $\begin{array}{l}\text { Gen } \\
\text { w/Obl.masc.sg. }\end{array}$ \\
\hline $\bar{a} p$ & apaṇe āp / àpe āp & apaṇe (āp nā) & apaṇı & apañā \\
\hline
\end{tabular}

The reflexive pronoun /āp/ 'self' is used whenever there is a need to indicate that the subject and not some other agent is acting, or that the subject is acting on the subject's own behalf or acting with respect to someone or something that is the subject's own. The analysis presented in Table 18 is only a partial paradigm of Eastern forms. Western dative and agentive forms in my data differ somewhat from those shown. Consider these Eastern examples:

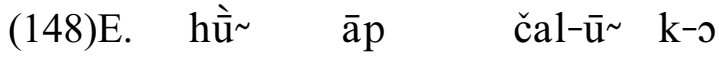

$$
\begin{aligned}
& \text { 1sg.NOM REFL.NOM go-1sg FUT-M.SG } \\
& \text { 'I myself will go.' } \\
& \text { (149)E. te āpe āp yó } \varepsilon^{\sim} \text { kam k-1̄-o hè } \\
& \text { 2sg.AG REFL.AG REFL.NOM 3sg.PROX.NOM.M work do-PERF-M.SG 2/3sg.PRES } \\
& \text { 'Have you yourself done this?' }
\end{aligned}
$$




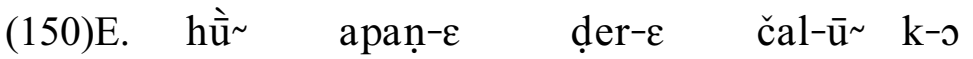

1sg.NOM REFL.GEN-LOC home-LOC go-1sg FUT-M.SG

'I will go to my own home.'

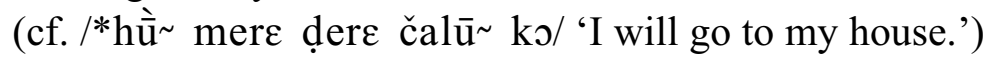

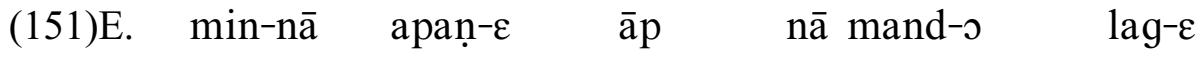

1sg.OBL-DAT REFL.GEN-LOC REFL.NOM DAT bad-NOM.M.SG attach-2/3sg

'I dislike myself.'

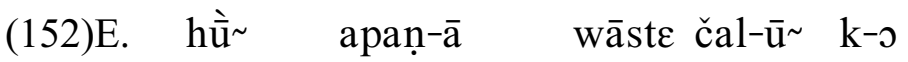

1sg.NOM REFL.GEN-OBL for go-1sg FUT-M.SG

'I will go for my own sake.'

\subsubsection{Adjectives}

Adjectives, like nouns, are of two types: unmarked stems, which by definition do not inflect; and marked adjectives which are structured as shown in (153):

\section{STEM - INFL}

In other words, marked adjectives consist of a stem followed by a single inflectional suffix; the stem of a marked adjective may not occur by itself.

Gojri adjectives of this type agree with their head nouns in gender (whether inherent or marked on the noun), number and, to a limited extent, in case. Masculine singular adjectives can therefore inflect to show locative and general oblique/vocative case agreement with a head noun so marked. In the Western dialect adjectives never take the oblique plural suffix, whereas in the Eastern dialect the oblique plural suffix is optional. Note example (154), in which the adjective (but not the possessive adjective) is marked with the oblique suffix; and (155), in which every stem in the noun phrase except the adjective is inflected with the oblique plural suffix / $/ \overline{\mathbf{a}} \sim /$ : 


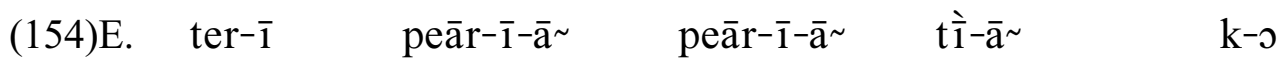
2sg.GEN-F.SG dear-F.SG-OBL.PL dear-F.SG-OBL.PL daughter-OBL.PL GEN-NOM.M.SG ke hàl hè what condition $2 / 3$ sg.PRES

'How are your beloved daughters?'

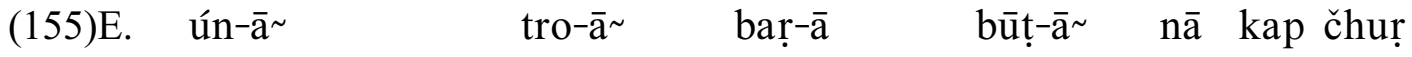
3pl.DIST.OBL-OBL.PL three-OBL.PL big-NOM.M.SG tree-OBL.PL DAT cut drop 'Cut down those three big trees!'

Adjectives may occur as substantives, that is, they may substitute for a full noun phrase as /búḍ̂̄/ 'old' does for /búḍ̄i mā̄i / 'old woman' in (156):

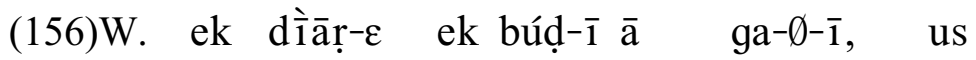
one day-LOC one old-F come go-PERF-F 3sg.DIST.OBL

ḍèn- $\overline{1} \quad \mathrm{k}-\varepsilon \quad$ der- $\varepsilon$.

woman-F GEN-LOC home-LOC

'One day an old woman came to that woman's home.'

Adjectives also serve as the predicate in stative constructions:

$$
\begin{aligned}
& \text { jaṇ-o manḍ-o th-o } \\
& \text { man-NOM.M.SG bad-NOM.M.SG PAST-M.SG } \\
& \text { 'The man was evil.' }
\end{aligned}
$$

The Specifier /āl-/ (/hà̀-/)

/ạl-/ combines with oblique nouns and adjectives, the oblique infinitive, and adverbs to specify a noun by its relation to another word. It agrees in gender, number, and case with the noun it modifies. It may be used as a substantive where the subject is understood. Consider example (158): 


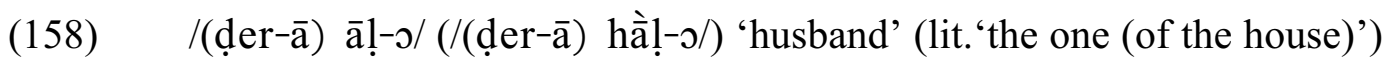

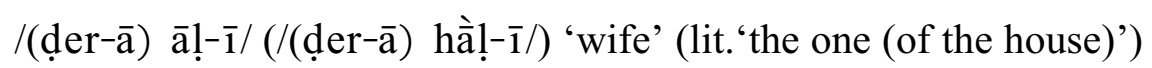

The Adjective Intensifier / ّ̌-/ / /̆a-/ 'very'

$/ \check{\mathfrak{j}}-/ \sim / \mathrm{ja}-/$ 'very' follows the adjective it modifies and agrees with it in gender, number, and case. It most frequently occurs in contexts where the head noun is in nominative case and focus position:

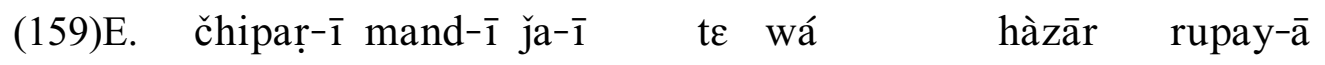
scarf-F.SG bad-F.SG very-F.SG and 3sg.DIST.NOM.F thousand rupee-NOM.M.PL nā $\quad \mathrm{d} \overline{1}-\varepsilon$

DAT give- $2 / 3 \mathrm{sg}$

'A very ugly scarf - she sells it for a thousand rupees.'

(160)E. xarč-o thoṛ-o ̌-o hò-e-o ná, expense-NOM.M.SG a.little-NOM.M.SG very-NOM.M.SG be-PERF-M.SG NEG

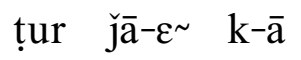
walk go-3pl FUT-M.PL

'Once [they earn] even a little expense money, they will move on.'

Interrogative, Relative, and Demonstrative Adjective Sets

Table 19. Interrogative, Relative, and Demonstrative Adjective Sets

\begin{tabular}{|c|c|c|c|}
\hline & Interrogative & Relative & Demonstrative \\
\hline of quantity & kitnā & jitnā & itnā \\
\hline of quality $\mathrm{E}$ & $k \varepsilon j ّ$ & ǰj & $\varepsilon$ ǰo \\
\hline W & kiso & jiso & iso \\
\hline
\end{tabular}




\subsubsection{Numerals}

According to Sharma (1982:143) and my research assistants, the traditional Gojri numeral system is a base-twenty, or vigesimal, system (cf. Baart 1999:57-59 for Kalami). This system is in flux, however, with Urdu multiples of five and ten entering into counting and replacing the traditional multiples of five, ten, and twenty (cf. old English ' 3 score' $=60$ ). In addition, numeric designations formed by subtracting the numbers one through five from the next multiple of ten (e.g. ' 3 less than 40 ' $=37$ ), and adding the last multiple of ten to the numbers one through five (e.g. ' 30 onto 3 ' $=33$ ), are in common use. These reflect a shift to a decimal or base-ten system. Among educated persons a standard decimal system is used, which remains distinct from the Urdu system at many points. It is not identical with Hindko or Punjabi, but may represent a Gojri pronunciation of that system. The addition/subtraction method may be a transitional method for those who are familiar only with multiples of ten from the standard decimal system.

The variety of counting techniques is illustrated by the variants for 'twenty-five', all

of which are perfectly acceptable: /panǰ te bí// ('5 and 20', vigesimal), /panjāa apar b⿳亠丷⿵冂/ ('20 onto 5', addition), /panj̄à kàt trī/ ('5 less [than] 30', subtraction), and /panj̄̄i/ ('25,' decimal). As I have yet to get any two informants to count fluently to one hundred in exactly the same fashion, I cannot report with confidence any series of numerals greater than forty that is distinctively Gojri. All three methods are shown in (161). 
(161) Gojri cardinal numbers 1-40

Vigesimal Method

1. $/ \mathrm{ek} /, / \mathrm{ik} /$

2. $/ \mathrm{do} /$

3. $/ \operatorname{trc} /$

4. /čār/

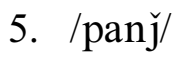

6. /čhe/

7. /sat/

8. /ath/

9. /no/

10. /das/ (/dáa)

11. /yārā /

12. /bārā /

13. /terā $/$

14. /čodā /

15. /pandarā /

16. /solā /

17. /satārā /

18. /aṭhārā /

19. /un̄̄/

20. /bí/

21. /ek te bí//

22. /do te bí//

23. $/ \operatorname{tr\varepsilon }$ te $\mathrm{b} \frac{\overline{1}}{1} /$

24. /čār te bó /

25. /panǰ te bí/

26. /čhe te bí/

27. /sat te bí1/

28. /ath te bí/

29. /no te bí/

30. /das te bí/ (/dấ te ból/)
Addition/Subtraction Method (mainly in my Eastern data)

/ek/, /ik/

/do/

$/ \operatorname{tr\varepsilon } /$

/čār/

/panj//

/čhe/

/sat/

/aṭh/

/no/

/das/

/yārā /

/bārā /

/terā /

/čodā /

/pandarā /

/solā /

/satārā /

/aṭhārā /

/un̄i/

/b产/

/ekụ apar bí/

/doā apar bó//

$/$ troā apar bí//

/čoā apar bó//

/panjā $\sim$ apar bí/,/panj̄ā kàt trī/

/čoā kàt trī/

/troā kàt trī/

/doā kàt trī/

/ekụ kàṭ trī/

$/ \operatorname{tr} \overline{\mathbf{1}} /$
Decimal Method

/ek/, /ik/

/do/

$/ \operatorname{tr\varepsilon } /$

/čār/

/panj//

/čhe/

/sat/

/aṭh/

/no/

/das/ (/dá/)

/yārā /

/bārā /

/terā /

/čodā /

/pandarā /

/solā /

/satārā /

/aṭhārā /

/unī/

/bí/

/ik $\overline{1} /$

/bāī/

$/ \operatorname{tr\varepsilon } \overline{\mathbf{1}} /$

/čawī/

/panǰ̄i/

/čhab̄̄/

/satāī/

/athā̄ī/

/unat $\overline{1}$ /, /unatrī/

$/ \operatorname{tr} \overline{\mathbf{1}} /$ 


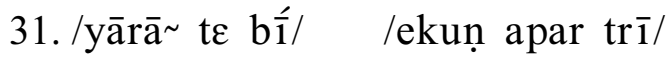

32. /bārā $\sim$ t $\varepsilon$ b $\overline{1} / /$ doā $\sim$ apar $\operatorname{tr} \overline{1} /$

33. /terā $\sim$ t $\varepsilon$ bí// /

34. /čodā $\operatorname{t\varepsilon }$ b $\overline{1} / / \quad / \check{c}^{\prime} \bar{a}^{\sim}$ apar $\operatorname{tr} \overline{1} /$

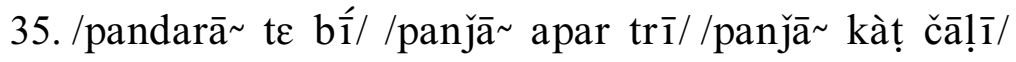

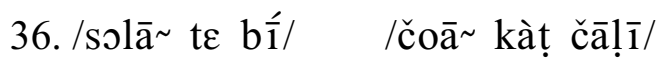

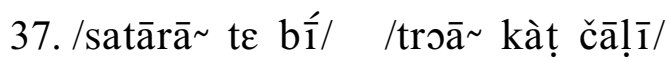

38. /aṭhārā $\sim$ te bí// /doā kàt čāḷî́/

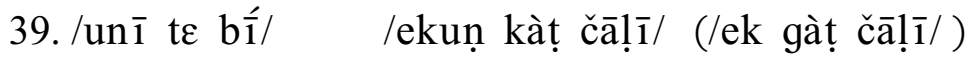

40. /do bí/ /čāḷi í /ikatīi/, /ikatrī/

/batī/,/batrī/

$/ \mathrm{t} \varepsilon \sim \overline{\mathrm{i}} /, / \mathrm{t} \varepsilon^{\sim} \operatorname{tr} \overline{\mathbf{1}} /$

/čs $\sim \overline{1} /, /$ čs $\sim \operatorname{tr} \overline{1} /$

/pentī/,/pentrī/

/čhatî̄, /čhatrī/

$/ \mathrm{s} \varepsilon^{\sim} \mathrm{t} \overline{1} /, / \operatorname{satatr} \overline{\mathbf{1}} /$

/aṭhatī/, /aṭhatrî//

/untāḷī/

/čāḷ̂̄/

The variant /ik/ 'one' or 'a' (approximating an indefinite article; cf. Masica 1991:370) is used as a quantifier but never in counting. Counting beyond forty with the traditional method follows the pattern shown in (161), adding the cardinals one through nineteen to subsequent multiples of twenty (/tre bí// 'sixty', /čār bî́/ 'eighty'), etc. Again, these multiples are frequently replaced with decimal system numerals. For example, a speaker will use the traditional numerals shown in (161) up to the number forty, at which point he or she may insert /čāḷ $1 \overline{1}$ ' forty' and then form subsequent numbers by addition to /čậ̣̂̄/ rather than to /do bí / 'two score.'

The remaining decimal system numbers through one hundred are shown in (162).

(162) Decimal system numbers 41-100 (cf. Sharma 1982:136-143)

\begin{tabular}{|c|c|c|c|c|}
\hline 41. /iktāḹîl & 42. /betāḷ̂̄/ & 43. /tartāḷ $\overline{1} /$ & 44. /čurtāḷ $\overline{1} /$ & 45. /pentāḷ $\overline{1} /$ \\
\hline 46. /čhetāḷ̂̄/ & 47. /satāḷ̂̄/ & 48. /aṭhtāḷî̀ & 49. /unwanjā/ & 50. /panǰ̄a/ \\
\hline 1. /ikwanjāa/ & 52. /bawanj̄̄a & 53. /tarwanjāa/ & 54. /čarwanjāa// & 55./pačwanj̄̄â/ \\
\hline 56. /čhewanjāā/ & 57. /satwanjāa/ & 58. /athwanjāa/ & 59. /unāṭh/ & 60. /sațh/ \\
\hline 1. /ikāṭh/ & 62. /bāțh/ & 63. /tre $\varepsilon^{\prime h} /$ & 64. /čo țh/ & 65./pențh/ \\
\hline 6. /čheātṭ/ & 67. /satāthh/ & 68. /aṭhātth/ & 69. /unattar/ & 70. /sattar/ \\
\hline 1. /ikattar/ & 72. /battar/ & 73. /trattar/ & 74. /čarattar/ & 75. /pačattar/ \\
\hline 6. /čheattar/ & 77. /satattar/ & 78. /aṭhatar/ & 79. /unās̄îl & 80. /as $\overline{1} /$ \\
\hline 1. /ikās̄î/ & 82. /bāsī/ & 83. /trās̄îl/ & 84. /čurās̄ī/ & 85. /pačās $\overline{1} /$ \\
\hline
\end{tabular}




\begin{tabular}{|c|c|c|c|c|}
\hline 86. /čheās $\overline{1} /$ & 87. /satāsī/ & 88. /aṭhās $\overline{1} /$ & $\begin{array}{l}\text { 89. /unānawe/ } \\
\text { /noās } \overline{1} /\end{array}$ & 90. /nawe/ \\
\hline 91. /ikānwe/ & 92. /bānwe/ & 93. /tarānawe/ & 94. /čurānwe/ & 95./pačānawe/ \\
\hline 96. /čheānawe/ & 97. /satānawe/ & 98. /athānawe/ & 99. /naṇānwe/ & 100. /so/ \\
\hline
\end{tabular}

For numbers greater than one hundred, the hundreds place value precedes whatever balance is represented by a smaller number shown in (161) or (162); for example, /ek so iktāḷ $\overline{1}$ / (one hundred forty-one) ' 141 '. Similarly, any thousands place value precedes the hundreds place value, e.g. /ek hàzār ek so iktāị̂̄/ (one thousand one hundred fortyone) ' 1141 '.

When followed by a postposition, Gojri cardinal numerals inflect to indicate oblique case. For example, consider the Eastern phrase /čoā̃ dèārā̄ (te bấd)/ '(after) four days'. The oblique forms, shown in (163), consist of the cardinal stems (modified for the numbers one through four) and the oblique plural suffix $/-\overline{\mathrm{a}} \sim /$. For the numbers eleven through eighteen, the oblique plural suffix coalesces with the stem-final vowel $/ \overline{\mathbf{a}} \sim /$.

(163) Oblique forms of cardinal numbers 1-10
1. /ekuṇ/ (/ike/)
11. /yārā /
2. /doā /
12. /bārā /
3. /troā /
13. /terā $/$
4. /čoā /
14. /čodā /
5. /panj̄̄̄ /
15. /pandarā /
6. /čheā /
16. /solā /
7. /satā $/$
17. /satārā /
8. /athā /
18. /athārā /
9. /noā $/$
19. /un $\overline{\bar{a}} \sim /$
10. /dasā $/$
20. /b́̄ $\bar{a} \sim /$

The Gojri ordinal numbers are shown in (164). Ordinals higher than 'fourth' show a consistent $/-\mathrm{m}-/$ ordinal suffix. Ordinal numbers agree in case with their head nouns; for 
example, the Eastern locative form /tī ǰ c dèậ̣/ 'on the third day.' My research assistants tell me that ordinals above /ikīmo/ 'twenty first' are not used.

(164) Gojri ordinals 1-20 (shown with masculine AC)
1. /pélo/ 'first'
11. /yārmo/ 'eleventh'
2. /dūjo/ 'second'
12. /bārmo/ 'twelfth'
3. $/ \mathrm{t} 1 \overline{\mathrm{j}} \mathrm{\textrm {j }} /$ 'third'
13. /terms/ 'thirteenth'
4. /čstho/ 'fourth'
14. /čodmo/ 'fourteenth'
5. /panjmo/ 'fifth'
15. /pandarmo/ 'fifteenth'
6. /čhemo/ 'sixth'
16. /solmo/ 'sixteenth'
7. /satmo/ 'seventh'
17. /satārmo/ 'seventeenth'
8. /ațhmo/ 'eighth'
18. /aṭhārmo/ 'eighteenth'
9. /noms/ 'ninth'
19. /unīmo/ 'nineteenth'
10. /dasmo/ 'tenth'
20. /bímo/ 'twentieth'

A few small numbers may be suffixed with /-e/ to indicate inclusion of all subjects: /ika/ (/ikoe/) 'just one, a single', /doe/ 'both', and /treē / 'all three.' It is possible that the Eastern indefinite masculine singular pronoun /kāe/ 'any' bears this same suffix, as it is most unusual for stems to end in /e/.

4.2 Verb-Phrase Constituents and Operations

\subsubsection{Verbal Forms and Categories}

\subsubsection{Structure of Gojri Finite Verbal Constructions}

For Gojri, the term 'finite verbal construction' is more useful than the term 'finite verb', which for other languages usually denotes the verb form bearing tense and agreement features. In Gojri, however, tense and aspect are not necessarily marked, and agreement may be marked on more than one element. Furthermore, verb forms which might be called 'participles' on account of their formal structure often function as the main verb, blurring the traditional distinction between 'finite' and 'non-finite' (dependent) 
forms. The term 'finite verbal construction', then, allows for reference to units that consist of more than one word, while avoiding the confusion created by associating participial forms with the category of 'finite verb.'

Gojri is polysynthetic to a degree, relying heavily on various verbal auxiliaries in addition to suffixation of the verb stem. The Gojri finite verbal constructions always include a main verb (which carries the lexical meaning and may also be marked for agreement features and tense or aspect), and they may include one or more auxiliaries.

The auxiliaries always occur to the right of the main verb. They add tense, aspectual, and modal meanings to the whole construction.

Structure of the Main Verb

The main verb in most Gojri finite verbal constructions is structured according to the two basic patterns shown in (165):

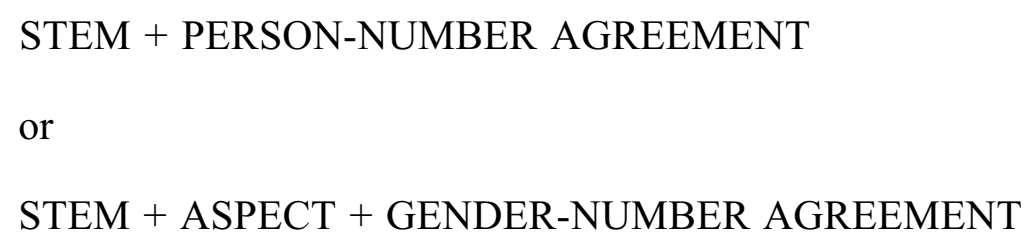

That is: stem, followed by a suffixed marker of person-number agreement ('personal concord, PC); or stem, followed by a suffixed marker of aspect, followed by a suffixed marker of gender-number agreement ('adjectival concord', AC). Verbs structured according to the first pattern are therefore unmarked for aspect and feature personal concord (PC; see Table 23). Verbs structured according to the second pattern are participial forms (see Table 24), marked for imperfective or perfective aspect and, like nouns and adjectives, featuring adjectival concord (AC).

Among verbs which are unmarked for aspect, there are two exceptions to the basic structural pattern: the Negated Future and the Future Imperative. Each of these forms 
features a unique future tense suffix between the verb stem and the PC suffix. The distribution of these suffixes is limited to specific forms and does not correlate with the future tense generally. Likewise, the slot in which they occur does not function generally for tense. Rather, tense is generally marked by auxiliaries.

The basic structure of the Gojri verb phrase is not distinct from that which Masica describes for NIA languages in general (1991:373-374). The Gojri verb phrase (VP) may consist of an adverb and one or more object and/or direction-specifying noun phrases (NP) to the left of the main verb (V), optionally followed by an adverb (rarely) and/or modal verb and as many as three tense/aspect auxiliaries. Any tense/aspect auxiliary is normally the final element. Negative particles are immediately to the left of the main verb, and their use is often accompanied by radical changes in the forms of other verb phrase constituents. This basic structure is summarized in (166).

$$
\mathrm{VP}=(\mathrm{NP})^{*}(\mathrm{Adv})(\mathrm{Neg})+\mathrm{V}(\mathrm{Adv})(\mathrm{MODAL})(\mathrm{Aux})^{*}
$$

(The asterisk $(*)$ indicates that more than one such constituent may occur in the specified location.)

\section{$\underline{\text { Concord Suffixes }}$}

Table 20. Personal Concord Suffixes (PC)

\begin{tabular}{|l|l|l|}
\hline & Eastern & Western \\
\hline $1 \mathrm{sg}$. & $-\overline{\mathrm{u}} \sim$ & $-\overline{\mathrm{u}} \sim$ \\
\hline $1 \mathrm{pl}$. & $-\overline{\mathrm{a}} \sim$ & $-\overline{\mathrm{a}} \sim$ \\
\hline $2 / 3 \mathrm{sg}$. & $-\varepsilon$ & $-\varepsilon$ \\
\hline $2 \mathrm{pl.}$ & -0 & $-\varepsilon$ \\
\hline $3 \mathrm{pl}$. & $-\varepsilon^{\sim}$ & $-\varepsilon$ \\
\hline
\end{tabular}


In the Western dialect, the second and third person distinctions found in Eastern are collapsed. The one exception is in the Western plural imperative, which has /-0 / where we might expect $/-\varepsilon /$ or $/-\varepsilon \sim$. Sharma's paradigm is basically the same as that shown here for Eastern, except that he reports /-e / rather than /- $/$ as the second person plural suffix (1982:167).

Table 21. Adjectival Concord Suffixes (AC)

\begin{tabular}{|l|l|l|}
\hline & Eastern & Western \\
\hline m.sg. & $-\jmath$ & $-\jmath$ \\
\hline m.pl. & $-\bar{a}$ & $-\overline{\mathrm{a}}$ \\
\hline f.sg. & $-\overline{1}$ & $-\overline{1}$ \\
\hline f.pl. & $-\overline{1} \sim$ & $-\overline{1}$ \\
\hline
\end{tabular}

As noted earlier (4.1.2), Western Gojri does not distinguish feminine plural from feminine singular. Otherwise the AC suffix inventory is identical for both dialects.

\subsubsection{Tense, Aspect, Mood, and Finite Verbal Constructions}

In this section I describe, in turn, the form and function of the primary finite verbal constructions. Table 22 summarizes the structure of each construction, excluding the imperatives and several dialect-specific constructions. I have included in this section only those combinations of morphemes which have been clearly grammaticalized for a unique tense/aspect/mood interpretation and which, except for the marginal Present Continuous II construction, involve only one verb. Later we shall see that further aspectual distinctions can be made through employment of a second verb. Throughout I have utilized Masica's terminology to facilitate ready comparison with his paradigms for Hindi-Urdu and Punjabi (1991:291-296). That Gojri encodes more distinctions than these related languages points to the age of its forms. Associated with this proliferation of 
Table 22. Primary Verbal Constructions (Eastern only)

\begin{tabular}{|c|c|c|c|}
\hline Tense/Aspect/Mood & Structure & Example & Translation \\
\hline $\begin{array}{l}\text { Unspecified Habitual - Contingent } \\
\text { Future }\end{array}$ & V-PC & 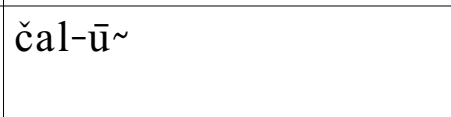 & 'I go'; 'I may go' \\
\hline Past Unspecified & V-PC PAST-AC & 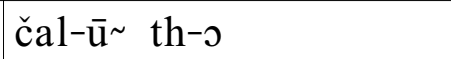 & 'I used to go' \\
\hline Definite Future & V-PC FUT-AC & čal- $\overline{\mathrm{u}} \sim \mathrm{k}-\mathrm{\jmath}$ & 'I will go' \\
\hline Present Continuous & V-PC /lag/-AC (/w/-AC) & čal- $\overline{\mathrm{u}} \sim$ lag-o (w-o) & 'I am going' \\
\hline Past Continuous & V-PC PAST-AC /lag/-AC (/w/-AC) & čal- $\overline{\mathrm{u}} \sim$ th-o lag-o $(\mathrm{w}-0)$ & 'I was going' \\
\hline Present Habitual & V-PC /ho/-PC & bes $-\overline{\mathrm{u}} \sim$ hò- $\overline{\mathrm{u}} \sim$ & 'I sit (repeatedly)' \\
\hline Past Habitual & V-PC /ho/-PC PAST-AC & 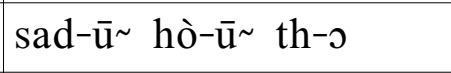 & 'I called (repeatedly)' \\
\hline Negated Future & $\mathrm{V}-/ \mathrm{s} /-\mathrm{PC}$ & čal-s-̄̄ $\sim$ & 'I will not go \\
\hline Habitual (Negated) - Contrafactive & V-IMPFV-AC & čal-t-o & 'he doesn't go'; 'he would go' \\
\hline Subjunctive Habitual & V-IMPFV-AC /ho/-PC & $\overline{\mathrm{a}}-\mathrm{t}-\mathrm{\jmath}$ hò-we & '(perhaps) he comes' \\
\hline Presumptive Habitual & V-IMPFV-AC /ho/-PC FUT-AC & $\bar{a}-\mathrm{t}-っ$ hò-we k-っ & 'he (probably) comes' \\
\hline Contrafactive Habitual & V-IMPFV-AC /ho/-IMPFV-AC & bes-t-o hò-t-o & 'if he had sat regularly' \\
\hline Unspecified Perfective & V-PERF-AC & sad-e-0 & 'he called' \\
\hline Present Perfective & V-PERF-AC PRES-PC & sad-e-o h`c & 'he has called' \\
\hline Past Perfective & V-PERF-AC PAST-AC & sad-e-o th-o & 'he had called' \\
\hline Presumptive Perfective & V-PERF-AC (/w/-AC) /ho/-PC FUT-AC & $g-\overline{1}-0(w-0)$ hò-we k-o & 'he must have gone' \\
\hline Contrafactive Perfective & V-PERF-AC /ho/-IMPFV-AC & $\bar{a}-e-o$ hò-t-o & 'if he had come' \\
\hline
\end{tabular}


formal and functional distinctions is the issue of negation, which for several tense/aspect/mood distinctions requires morphology that in no way resembles that required by these same distinctions in the positive.

Gojri distinguishes present, past, and future tense. Present actions or events are indicated by the unspecified verb (stem + PC), and elsewhere by a present auxiliary form of /hò-/ 'be' (see 4.2.1.1.5). There are two strategies for indicating past actions or events: the perfective form of the verb (stem $+/-\mathrm{e} /(/-\overline{1} /)+\mathrm{AC})$ with no tense auxiliary indicates past time (in simple clause structures), while the past auxiliary /th-/ explicitly specifies past time. There are three markers of future tense: the future auxiliary $/ \mathrm{k}-/(/ \mathrm{g}-/)$ for positive constructions, the suffix /-s/ for negative constructions, and the suffix $/-\overline{1} /(/-\overline{1} \sim /)$ for imperatives. Various aspectual distinctions possible with past and present time are neutralized in the future.

Aspectually, the primary formal distinction in the Gojri finite verb is between forms marked for aspect and those which are unmarked for aspect, variously taking AC and PC suffixes, respectively. The basic aspectual distinction is between perfective and imperfective aspect. Perfective aspect, which views the verbal event as a whole, is indicated by the suffix /-e/ $(/-\overline{1} /)$ in main verbs bearing $\mathrm{AC}$ agreement. This suffix coalesces with the feminine AC suffixes $/-\overline{1} /$ and $/-\overline{1} \sim /$ such that it is not phonetically realized in feminine forms (it is therefore shown as $/-\varnothing /$ before feminine suffixes in the

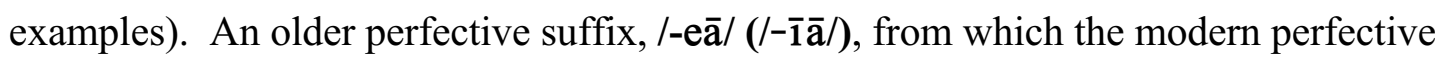
suffix evolved and which is itself the remnant of an earlier Sanskrit /-ita/ suffix (Masica 1991:269), still survives in one type of compound imperative (see discussion of $/ \mathrm{kar}-/$ 'do' in 4.2.2.3) and in one Eastern contrafactive form (see 4.2.1.3). It attaches directly to 
the verb stem and does not take an AC suffix, nor does it itself agree with any noun (it only appears to agree with the masculine plural).

Imperfective aspect, which views the verbal event as incomplete, is futher subdivided into distinctions of unspecified, habitual, and continuous aspect. Unspecified imperfective aspect is unmarked, i.e. it is indicated by the verb stem and AC suffix without any other marker. Habitual aspect is indicated variously by the suffix /-t/ in main verbs bearing AC agreement and in participles, and by the auxiliary /hò-/ 'be'.

Continuous aspect is marked by the auxiliary /lag-/ followed by the perfective participle marker /w-/ (Eastern only), and by the auxiliary /ré-/ 'stay' in certain Eastern constructions.

Mood (or 'mode') 'describes the speaker's atitude toward a situation, including the speaker's belief in its reality, or likelihood' (Payne 1997:244). Gojri, like some other NIA languages including Kalami (Baart 1999:113), lacks any morphological marking of mood, although important functional distinctions are indicated by intonation patterns and/or combinations of tense and aspect marking. Actual or 'real' verbal events are described by realis mood, a broad category that in Gojri includes many imperfectives and all perfectives other than those occurring in conditionals. All instances of realis mood are negated by the negative particle $/ \mathrm{n} \frac{1}{1} /$ (the converse doesn't hold).

Events which are potential rather than actual from the speaker's standpoint are described by irrealis mood. The irrealis interpretations occurring in Gojri apart from any marker of aspect include the following for the Eastern verb / (tam) čal-っ / '(you pl.) go' (note that all are associated with the same form): (1) imperative mood ('You pl. go!'), with extra stress on the verb stem; (2) interrogative mood ('You go?'), with rising 
intonation that peaks utterance-finally; and (3) subjunctive mood ('You should go.'), with unmarked intonation identical to that for the Unspecified Habitual ('You go.') such that the two meanings are distinguished only by context. Two irrealis interpretations occurring with a marker of aspect are contrafactive mood and presumptive mood (e.g. 'you don't go', 'you will have gone;' respectively). All Gojri verb forms negated by the particle /ná/ are irrealis mood (the converse doesn't hold).

\subsection{Finite Verbal Constructions Based on Forms Unmarked for Aspect}

The Unspecified Habitual - Contingent Future consists of the verb stem with PC suffix, without any marker of tense or aspect. This form represents a retention of the 'Old Present' parallel to that surviving in Sindhi (Masica 1991:274).

$$
\begin{aligned}
& \text { hì̀ } \quad \check{c} a l-\bar{u}^{\sim} \\
& \text { 1sg.NOM go-1 } \\
& \text { 'I go.' }
\end{aligned}
$$

The Contingent Future, or 'subjunctive', is distinguished from the Unspecified Habitual only by context and, when occurring as it frequently does with the interrogative, by rising intonation. The Unspecified Habitual refers to habitual action rather than to any specific event (cf. Payne 1997:240), while the Contingent Future normally expresses advisability, permissibility, or desireability of a specific action ('I should go.' / 'May I go?'), including such expressions in conditional clauses ('If I go ...') (Masica 1991:281-282). Compare (168) with (169):

$$
\begin{aligned}
& \text { hàm bazār nā čal-ā̃ } \\
& \text { 1pl.NOM bazaar DAT go-1pl }
\end{aligned}
$$

'We go to the bazaar.' / 'We should go to the bazaar.' 


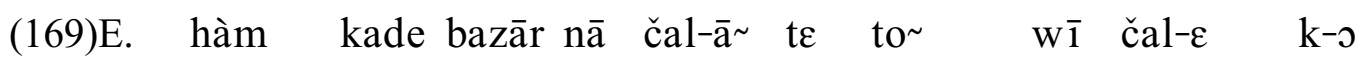
1pl.NOM if bazaar DAT go-1pl then 2 sg.NOM also go-2/3sg FUT-M.SG 'If we go to the bazaar, will you go too?'

Unspecified Habitual verbs can only be negated as such (i.e. without change in form) in the presence of another negated verb, and then only by the negative particle /ná/ placed ahead of the verb. Such constructions are similar to the English ' ... neither V1 ... nor V2' and '... not V1 ... nor V2.' The former is illustrated in (170) and (171) and the latter in (172):

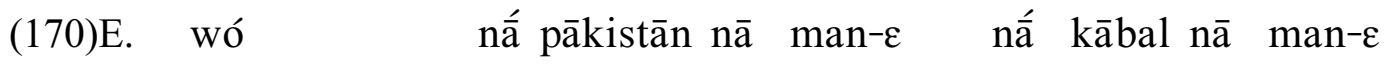
3sg.DIST.NOM.M NEG Pakistan DAT obey-2/3sg NEG Kabul DAT obey-2/3sg 'It obeys neither Pakistan nor Kabul.'

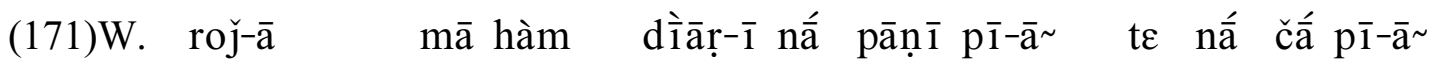
fast-OBL.M.SG in 1sg.NOM day-F NEG water drink-1pl and NEG tea drink-1pl 'During the fast we neither drink water during the day, nor do we drink tea.'

Negative habitual notions occurring without another negated verb in constructions unmarked for tense, or occurring in constructions of the type '... not V' such as that in (172), can only be expressed by means of the imperfective form of the verb preceded by the negative /n⿳亠丷⿵冂/, as in /n⿳亠丷厂 čalts/ '[he] does not go' (see Habitual (Negated) - Unspecified Contrafactive below).

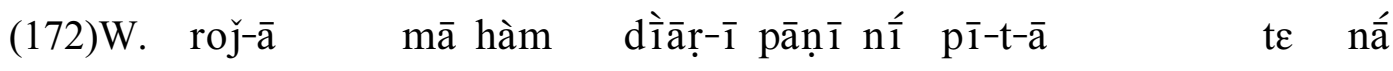
fast-OBL.M.SG in 1sg.NOM day-F water NEG drink-IMPFV-M.PL and NEG čá $\mathrm{p} \overline{\mathbf{1}}-\overline{\mathrm{a}} \sim$ tea drink-1sg 'During the fast we don't drink water during the day, neither do we drink tea.' 
Contingent future verbs may also be negated only by a preceding /ná/.

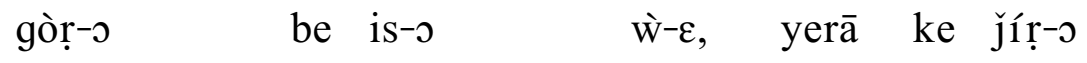

horse-NOM.M.SG also such-NOM.M.SG be-2/3 namely that REL-NOM.M.SG

dor ná hàk-e

run $\mathrm{NEG}$ be.able-2/3

'The horse should be such, namely, one that won't be able to run.'

The Negated Future consists of the verb stem with future tense suffix /-s/ and a PC suffix, preceded by the negative particle $/ \mathrm{n} \frac{1}{1} /$ :

$$
\begin{aligned}
& \text { h⿳亠े⿵ } \sim \quad n \frac{1}{1} \quad \check{c} a l-s-\bar{u} \sim \\
& \text { 1sg.NOM NEG go-FUT-1sg } \\
& \text { 'I will not go.' }
\end{aligned}
$$

In the Western dialect only, this form may also occur with the future auxiliary $/ g-/$ :

$$
\begin{array}{llll}
\text { wó } & \text { nó } & \text { čal-s-e } & \text { g-o } \\
\text { 2sg.DIST.NOM.M NEG } & \text { go-FUT-2/3 } & \text { FUT-M.SG } \\
\text { 'He will not go.' } &
\end{array}
$$

The Present Imperative consists of the verb stem alone in the singular, while the plural is formed by adding the second person PC suffix /-o/ (/-0 /) to the verb stem (note that the Western second person PC suffix is /-ع/ everywhere else):

(176)E. to čal! 'You (sg.) go now!' tam čals! 'You (pl.) go now!'

W. to čal! 'You (sg.) go now!' tam čalo ! 'You (pl.) go now!'

The Present Imperative is negated by the particle /ná/.

The Future Imperative is formed by adding the future suffix $/-\overline{1} /(/-\overline{1} \sim /)$ and the second person singular /-e/ and plural /-っ/ (/-0 /) PC suffixes to the verb stem: 
(177)E. to čalīe! 'You (sg.) go!'

tam čalīo! 'You (pl.) go!'

W. to čalī e! 'You (sg.) go!'

tam čalī $\sim 0^{\sim !}$ 'You (pl.) go!'

The nasality of the Western Future Imperative suffix formally distinguishes such forms as the plural Future Imperative, $/ \overline{\mathbf{a}} \overline{\mathbf{1}} \Upsilon^{\sim} /$ 'You come (later)!', from the masculine singular perfect, /āî̃/ 'I/You/He came.' Vowel quality alone distinguishes these in Eastern speech: /ā̄̄o/ 'You come (later!)' vs. /āeə/ 'I/You/He came.'

Occasionally the Future Imperative may be used in the present for politeness, possibly due to influence from Urdu. Politeness is normally expressed in the Eastern dialect by adding the request particle /dā $/$ 'please' after the imperative (whether present or future):

(178)E. zarī apaṇ-ā xat mā likh-î̀-e dā a.little REFL-OBL.M.SG letter in write-FUT-2sg please 'Please write a little [about it] in your letter.'

In the Western singular form of the future imperative, the personal concord suffix /-e/, which normally follows the future imperative suffix, may elide in normal speech:

(179)W. mer-o xyāl kar-ī̃

1sg.GEN-NOM.M.SG thought do-FUT.IMPV

'Think about me.'

The Future Imperative is also negated by the particle /nă/.

\subsection{Finite Verbal Constructions Based on Forms Marked for Aspect}

The Habitual (Negated) - Unspecified Contrafactive consists of the imperfective form of the verb (stem + imperfective suffix $/-t /+$ AC suffix). The most common use of this construction is for Present Habitual verbs negated by the particle /n⿳亠丷厂́/. Like the 
Unspecified Habitual-Contingent Future (see 4.2.1.2.1), it is capable of both habitual and contingent future interpretations:

$$
\begin{aligned}
& \text { h⿳亠े⿵ } \quad \text { n⿳亠丷厂 } \\
& \text { 1sg.NOM NEG go-IMPFV-M.SG } \\
& \text { 'I do not go.' / 'I will not go.' }
\end{aligned}
$$

In conditional clauses negated by $/ \mathrm{n} \frac{1}{1} /$, the interpretation is always contingent future:

$$
\begin{aligned}
& \text { wó kade } \mathrm{n}^{\frac{1}{1}} \text { čal-t-o te hù } \mathrm{n} \frac{\dot{1}}{\mathrm{u}} \text { čal-t-o } \\
& \text { 3sg.DIST.NOM.M if NEG go-IMPFV-M.SG then } 1 \mathrm{sg} \text {.NOM NEG go-IMPFV-M.SG } \\
& \text { 'If he will not go, then I will not go.' }
\end{aligned}
$$

When preceded or followed by the negative /náa/, the imperfective form of the verb has a simple contrafactive meaning. Compare the negated present habitual in (182)a. with the contrafactives in (182)b., (182)c., and (183):

$$
\begin{aligned}
& \text { (182)E.a. to }{ }^{\sim} \text { ní pakā-t-o } \\
& \text { 2sg.NOM NEG cook-IMPFV-M.SG } \\
& \text { 'You do not cook.' }
\end{aligned}
$$

(183)W. to pélā pakā-t-o, ke hòn tak yé ṭanḍ-ī

1sg.NOM earlier IMPFV-M.SG that now until 3pl.PROX.NOM cold-F

hò jāâ-t-ì

be go-IMPFV-F

'You should have cooked earlier, so that these could have cooled off by now.' 
The Habitual (Negated) - Unspecified Contrafactive also occurs in contrafactive conditional constructions (see 4.2.1.3).

The Unspecified Perfective consists of the perfective form of the verb (stem + perfective suffix $/-\mathrm{e} /(/-\overline{1} /)+\mathrm{AC}$ suffix $)$. This form presents the verbal action as a completed whole, without reference to its timing. Most often it correlates with simple past tense as in (184) and (185), but future interpretations are also abundant in conditionals like those in (186) and (187):

hì $\sim \quad g-\overline{1}-\jmath$

1sg.NOM go-PERF-M.SG

'I went.'

(185)E.

us ne akram sad-e-o

3sg.DIST.OBL AG Akram call-PERF-M.SG

'He/she called Akram.'

(186)E.

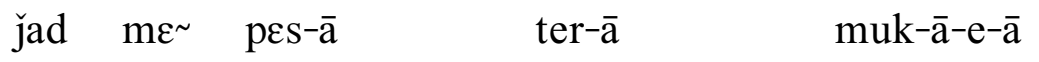

when 1sg.AG money-NOM.M.PL 2sg.GEN-NOM.M.PL finish-CAUS-PERF-M.PL

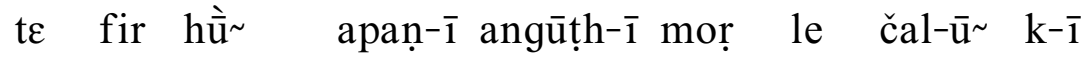

then then 1sg.NOM REFL-F ring-F return take go-1sg GEN-F

'When I finish [paying off] your money then I will take back my ring and go.'

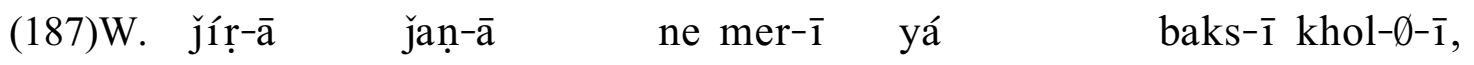
REL-OBL.M.SG man-OBL.M.SG AG 1sg.GEN-F 3sg.PROX.NOM.F box-F open-PERF-F

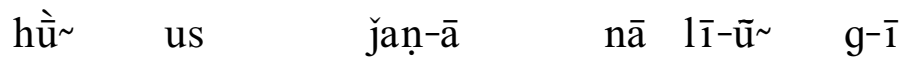

1sg.NOM 3sg.DIST.OBL man-OBL.M.SG DAT take-1sg FUT-F

'Whichever man opens this box of mine, that man I will take.'

A number of common irregular (unspecified) perfective forms attest the Sanskrit /-ita/ suffix: /dittı/ 'given', /ḍițtho/ 'seen', /națțo 'ran away', /beṭho/ 'seated', and /suttı/ 
'slept'. Some such forms are instances of pure suppletion, while others at least feature the expected initial consonant. All take the regular AC suffixes (the examples shown feature masculine singular agreement).

\subsection{Verbal Inflections}

The paradigms in tables 23 and 24 present formal distinctions only; functional distinctions are explained further below. Here the forms are labeled according to whatever function each has in isolation, even though the same forms may have other functions when occurring in combination with another verb or verbal auxiliary. Paradigms for representative verbs ending in vowels are given in Appendix C.

Table 23. Gojri Verb Forms Unmarked for Aspect; Stem Ends in Consonant: /sad-/ 'call' (unique Western forms are in parentheses)

\begin{tabular}{|c|c|c|c|c|c|}
\hline & & Stem & (Tense) & $\mathrm{PC}$ & Full form \\
\hline \multirow[t]{5}{*}{ Unspecified Habitual } & $1 \mathrm{sg}$. & sad- & & $-\overline{\mathrm{u}} \sim$ & $\operatorname{sad}^{\sim}$ \\
\hline & $1 \mathrm{pl}$. & sad- & & $-\overline{\mathrm{a}}^{\sim}$ & sadā $\sim$ \\
\hline & $2 / 3 \mathrm{sg}$. & sad- & & $-\varepsilon$ & sad $\varepsilon$ \\
\hline & $2 \mathrm{pl}$ & sad- & & $-0(-\varepsilon)$ & $\operatorname{sad} \rho(\operatorname{sad} \varepsilon)$ \\
\hline & $3 \mathrm{pl}$. & sad- & & $-\varepsilon^{\sim}(-\varepsilon)$ & $\operatorname{sad} \varepsilon^{\sim}(\operatorname{sad} \varepsilon)$ \\
\hline \multirow[t]{5}{*}{ Negated Future } & 1sg. & sad- & $-S$ & $-\overline{\mathrm{u}} \sim$ & $\operatorname{sad} s \bar{u} \sim$ \\
\hline & $1 \mathrm{pl}$. & sad- & $-\mathrm{S}$ & $-\overline{\mathrm{a}}^{\sim}$ & sadsā $\sim$ \\
\hline & $2 / 3 \mathrm{sg}$. & sad- & $-S$ & $-\varepsilon$ & sadse \\
\hline & $2 \mathrm{pl}$ & sad- & $-S$ & $-0(-\varepsilon)$ & sadso (sadse) \\
\hline & $3 \mathrm{pl}$ & sad- & $-\mathrm{S}$ & $-\varepsilon^{\sim}(-\varepsilon)$ & $\operatorname{sads\varepsilon } \sim(\operatorname{sads} \varepsilon)$ \\
\hline \multirow[t]{2}{*}{ Present Imperative } & $2 \mathrm{sg}$. & sad- & & $\emptyset$ & $\mathrm{sad}$ \\
\hline & $2 \mathrm{pl}$ & sad- & & $-0\left(-0^{\sim}\right)$ & sado (sado $)$ \\
\hline \multirow[t]{2}{*}{ Future Imperative } & $2 \mathrm{sg}$. & sad- & $-\overline{1} \quad(-\overline{1} \sim)$ & $-\mathrm{e}$ & $\operatorname{sad} \overline{1} \mathrm{e}(\operatorname{sad} \overline{1} \sim \mathrm{e})$ \\
\hline & $2 \mathrm{pl}$ & sad- & $-\overline{1} \quad\left(-\overline{1}^{\sim}\right)$ & $-0\left(-\jmath^{\sim}\right)$ & $\operatorname{sad}^{1} \supset\left(\operatorname{sad}^{\prime} \sim \jmath^{\sim}\right)$ \\
\hline
\end{tabular}


Table 24. Gojri Verb Forms Marked for Aspect; Stem Ends in Consonant: /sad-/ 'call' (unique Western forms are in parentheses)

\begin{tabular}{|c|c|c|c|c|c|}
\hline & & Stem & Asp & $\mathrm{AC}$ & Full form \\
\hline \multirow[t]{4}{*}{ Habitual (Negated) } & m.sg. & sad- & $-t$ & -0 & sadto \\
\hline & m.pl. & sad- & $-t$ & $-\overline{\mathrm{a}}$ & sadtā \\
\hline & f.sg. & sad- & $-\mathrm{t}$ & $-\overline{1}$ & sadtī \\
\hline & f.pl. & sad- & $-\mathrm{t}$ & $-\overline{1} \sim(-\overline{1})$ & $\operatorname{sadt} \overline{\mathbf{1}} \sim^{\sim}(\operatorname{sadt} \overline{1})$ \\
\hline \multirow[t]{4}{*}{ Unspecified Perfective } & m.sg. & sad- & -e $(-\overline{1})$ & -0 & sadeo $(\operatorname{sad} 1 \overline{0})$ \\
\hline & m.pl. & sad- & -e $(-\overline{1})$ & $-\overline{\mathrm{a}}$ & sadeā $(\operatorname{sad} \overline{1} \bar{a})$ \\
\hline & f.sg. & sad- & -e $(-\overline{1})$ & $-\overline{1}$ & $\operatorname{sad} \overline{1}$ \\
\hline & f.pl. & sad- & -e $(-\overline{1})$ & $-\overline{1}^{\sim} \sim(-\overline{1})$ & $\operatorname{sad} \overline{1}^{\sim} \sim(\operatorname{sad} \overline{1})$ \\
\hline
\end{tabular}

\subsection{Finite Verbal Constructions Involving Tense Auxiliaries}

\section{Constructions Involving the Present Auxiliary $/ \mathrm{h}-/(/ \mathcal{\varepsilon} /)$}

The present auxiliary specifies present time. In the Eastern dialect the present auxiliary paradigm consists of the full inventory of PC suffixes attached to a stem, $/ \mathrm{h}-/$ (a reduction of the verb /hò-/ 'be'), while in the Western dialect the paradigm has collapsed down to the second and third singular, and that without any vestige of the verb stem. Table 25. Present Auxiliary

\begin{tabular}{|c|c|c|}
\hline & Eastern & Western \\
\hline $1 \mathrm{sg}$. & hì $\sim$ & $\varepsilon$ \\
\hline 1 pl. & 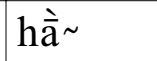 & $\varepsilon$ \\
\hline 2/3 sg. & hè & $\varepsilon$ \\
\hline $2 \mathrm{pl}$. & hò & $\varepsilon$ \\
\hline 3 pl. & hغ̀ & $\varepsilon$ \\
\hline
\end{tabular}

The variation shown in Table 25 constitutes one of the more salient differences between the dialects. Sharma's paradigm is basically the same as that given here for the 
Eastern dialect, only with the $2 \mathrm{pl}$ and $3 \mathrm{pl}$ forms collapsed as /hè / (1982:176,100). He

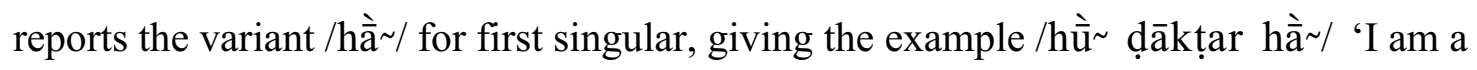
doctor' (1982:176-177; transcriptions mine). While this sentence is ungrammatical in the speech of my Eastern and Western research assistants, the auxiliary variant itself is familiar from Hindko and certain Eastern contrafactive constructions (see 4.2.1.3).

The present auxiliary is the right-most constituent of the constructions in which it occurs. In negation, the present auxiliary is replaced with the negative particle $/ \mathrm{n} \dot{1} /$. When occurring by itself without any other verb, it is the copula, linking a noun phrase subject with some specifying static quality or identification in present time, or merely

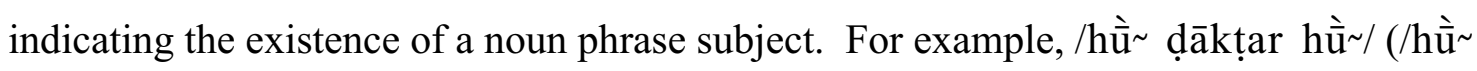
ḍākṭar $\varepsilon /$ ) 'I am a doctor.'

The Present Perfective consists of the perfective form of the verb followed by the present auxiliary $/ \mathrm{h}-/(/ \varepsilon /)$. It signifies that the verbal action 'has been' completed with respect to the present. (188)E.
ne akram sad-e-o
hغ̀
3sg.DIST.OBL AG Akram call-PERF-M.SG 2/3sg.PRES
'He/she has called Akram [and he's not here yet].'
(189)E.
$\begin{array}{lllll}\mathrm{m}^{\sim} & \operatorname{rot}-\overline{1} & \mathrm{kha} & \mathrm{d}-\emptyset-\overline{1} & \text { hè } \\ \text { 1sg.AG } & \text { bread-F.SG } & \text { eat } & \text { give-PERF-F.SG } & \text { 2/3sg.PRES }\end{array}$
'I have eaten.'
(190)W. me te hòn allā k-ā hùkam nạl šarū kar- 1sg.AG and now Allah GEN-OBL.M.SG command with start do-PERF-F PRES 'Now by Allah's command I have made a start.'


Constructions Involving the Past Auxiliary /th-/

The past auxiliary, which specifies past time, consists of a root, /th-/, and an AC suffix. It occurs to the right of the main verb, with or without one or more intervening auxiliaries or other grammatical words, and serves as the copula in past stative constructions:

$$
\begin{aligned}
& \text { ó is ilāk-ā mālik th-o } \\
& \text { 3sg.DIST 3sg.DIST.OBL area-OBL.M.SG GEN-NOM.M.SG owner PAST-M.SG } \\
& \text { 'He was the owner of this area.' }
\end{aligned}
$$

The Past Unspecified consists of the verb stem with PC suffix followed by the past auxiliary /th-/:

$$
\begin{array}{lll}
\text { h } \overline{\bar{u}} \sim & \check{c} a l-\bar{u} \sim & \text { th-o } \\
\text { 1sg.NOM } & \text { go-1sg } & \text { PAST-M.SG }
\end{array}
$$

'I used to go.'

(193)W. Wó

$$
\text { muč dar- } \varepsilon \text { th-o laṛā-̄ te }
$$

3s.DIST.NOM.M very fear-2/3 PAST-M.SG fight-F from

'He was very afraid of battle.'

(194)W. agl-ā

lok muč dẹádị-ā $\quad$ we $-\varepsilon \quad$ th-a

former-NOM.M.PL people very strong-NOM.M.PL be-2/3 PAST-M.PL

'The people of old were very tough.'

This form is negated by the particle /n⿳亠丷厂彡/ without inducing any morphological change:

$$
\begin{aligned}
& \text { hì̀ } \quad \mathrm{n} \frac{\dot{1}}{\mathrm{c} a l}-\overline{\mathrm{u}} \sim \text { th-o } \\
& \text { 1sg.NOM NEG go-1sg PAST-M.SG } \\
& \text { 'I used to not go.' }
\end{aligned}
$$


The Past Perfective consists of the perfective form of the verb followed by the past auxiliary $/$ th - . It signifies that the verbal action was completed at an earlier time:

$$
\begin{array}{lll}
\text { hù̀ } & g-\overline{1}-\jmath & \text { th- } \\
\text { 1sg.NOM } & \text { go-PERF-M.SG } & \text { PAST.M.SG }
\end{array}
$$

'I went [at an earlier time].'

(197)E.

us ne akram sad-e-0 th-0
3sg.DIST.OBL AG Akram call-PERF-M.SG
'I called Akram [at an earlier time].'

Constructions Involving the Future Auxiliary $/ \mathrm{k}-/(/ \mathrm{g}-/)$

The future auxiliary, specifying future time, consists of a root, $/ \mathrm{k}-/\left(/ \mathrm{g}^{-} /\right)$, and an $\mathrm{AC}$ suffix. Normally it occurs immediately to the right of the main verb as shown in (198), but the root is not fully suffixed as it has become in Urdu and Punjabi (cf. Masica 1991:288-289). Rarely, as in (199), the adverb /w $\overline{1} /$ (/bì /, /be/) 'also' may intervene between the main verb and future auxiliary.

(198)W. ras-o saṭ te hàm čár-ā̃ g-ī

rope-NOM.M.SG throw and 1pl.NOM climb.1pl FUT-F

'Throw the rope and we will climb [out]!'

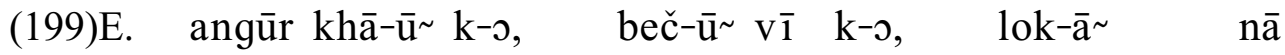
grapes eat-1sg FUT-M.SG sell-1sg also FUT-M.SG people-OBL.PL DAT

$\mathrm{d} \overline{\mathrm{i}}-\overline{\mathrm{u}} \sim \quad \mathrm{k}-\mathrm{\jmath}$

give-1sg GEN-M.SG

'I will eat the grapes. I will also sell [them]. I will give [them] to people.'

The Definite Future consists of the verb stem with PC suffix followed by the future auxiliary $/ \mathrm{k}-/(/ \mathrm{g}-/)$ : 


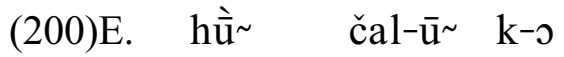

1sg.NOM go-1sg FUT-NOM.M.SG

'I will go.'

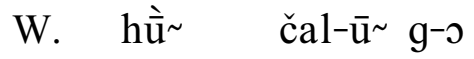

1sg.NOM go-1sg FUT-NOM.M.SG

'I will go.'

This form cannot be used with a negative of any type.

4.2.1.2.5 Finite Verbal Constructions Involving Other Auxiliaries

Constructions Involving /hò-/ 'be'

The verb /hò-/ serves as an important auxiliary in many verbal constructions (cf.

Masica 1991:285-286). In its unspecified form it can also be used as a main verb in the present or past to express habitual aspect, indicating that a particular state of affairs usually holds, as in (201), or typically held, as in (202):2

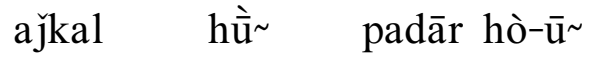

$$
\begin{aligned}
& \text { nowadays } 1 \text { sg.NOM busy be-1sg }
\end{aligned}
$$

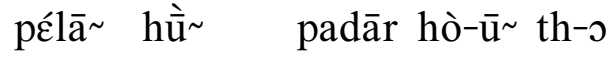

$$
\begin{aligned}
& \text { before 1sg.NOM busy be-1sg PAST-NOM.M.SG } \\
& \text { 'I used to be busy.' (lit. 'Before, I was busy.') }
\end{aligned}
$$

With the future auxiliary $/ \mathrm{k}-/(/ \mathrm{g}-/)$, the unspecified form of /hò-/ indicates that a particular state of affairs will hold in the future (cf. the Definite Future in 4.2.1.2.4), without specifying habitual aspect: 


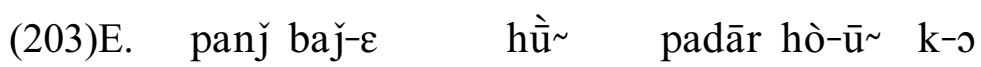

five o'clock-LOC 1sg.NOM busy be-1sg FUT-NOM.M.SG

'At five o'clock I will be busy.'

Some important inflections of /hò-/ are shown in Table 26 (its full paradigm is given in Appendix C).

Table 26. Inflections of /hò-/ 'be'

\begin{tabular}{|c|c|c|c|}
\hline & & Eastern & Western \\
\hline \multirow[t]{5}{*}{ unspecified } & 1sg. & 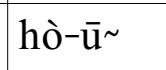 & hò-̄̄ $\sim$ \\
\hline & 1pl. & hò-wā $\sim$ & $w^{-\bar{a}} \sim$ \\
\hline & $2 / 3$ sg. & hò-we & $w^{\prime} \varepsilon$ \\
\hline & $2 \mathrm{pl}$. & hò-wo & $w^{\prime} \varepsilon$ \\
\hline & $3 \mathrm{pl}$. & hò-we & $w ` \varepsilon$ \\
\hline \multirow[t]{4}{*}{ imperfective } & m.sg. & hò-t-o & hò-t-o \\
\hline & m.pl. & hò-t-ā & hò-t-ā \\
\hline & f.sg. & hò-t-ì & hò-t-i \\
\hline & f.pl. & hò-t- $\overline{1} \sim$ & hò-t-i \\
\hline
\end{tabular}

In Western, /hò-/ has been lost in all unspecified forms except the first singular, leaving formerly epenthetic $/ \mathrm{w} /$ (and a low-rising tone) as the verb stem. In this respect the Western form has evolved exactly opposite from the direction noted for Hindi-Urdu, where the subjunctive /ho/ is now preferred to the older/hove/ (Masica 1991:293; transcription his). In between the Kaghani (Eastern) and Allaiwal (Western) forms reported here are a range of transitional forms that may be heard in the speech of other Gujars. 
The Present Habitual consists of the verb stem with PC suffix followed by the unspecified form of /hò-/ 'be'. It describes a verbal action performed repeatedly over an indefinite period of time which includes the present. While the 'unspecified' constructions normally indicate habitual interpretations, the addition of /hò-/ marks habitual aspect explicitly. This construction cannot as such be negated; rather, its negative counterpart is the Contrafactive Habitual:

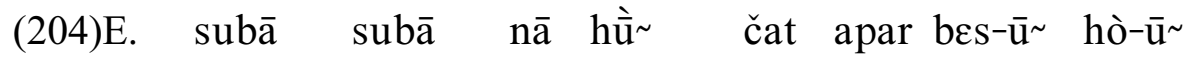
morning morning DAT 1sg.NOM roof on sit-1sg be-1sg 'I sit on the roof every morning.'

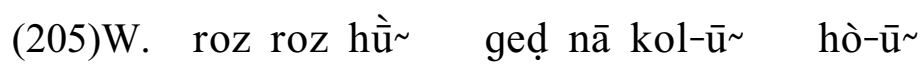
day day $1 \mathrm{sg}$.NOM gate DAT open-1sg be-1sg

'I open the gate every morning.'

The Past Habitual consists of the verb stem with PC suffix followed by the unspecified form of /hò-/ 'be' and the past auxiliary /th-/. It describes a habitual verbal action performed over an indefinite period of past time:

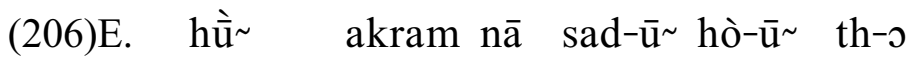
1sg.NOM Akram DAT call-1sg be-1sg PAST-M.SG

'I used to call Akram on a regular basis.'

(207)W. mer-s nān-o timrī mā

1sg.GEN-NOM.M.SG maternal.grandfather Timri in

'́r- $\varepsilon \quad$ Ẁ- $\varepsilon$ th-o

stay- $2 / 3$ be- $2 / 3$ PAST-M.SG

'My grandfather used to live in Timri.'

The Past Habitual is negated simply by inserting the particle $/ \mathrm{n} \frac{\dot{1}}{\mathrm{l}} /$ before the main verb: 


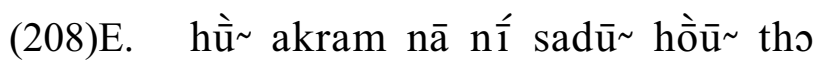

'I didn't used to call Akram on a regular basis.'

The Subjunctive Habitual consists of the imperfective form of the verb followed by the unspecified form of /hò-/ 'be'. It describes a verbal action which the speaker views as possible. This form is comparatively rare, and in my data occurs only with the idiom /ke patto/ 'perhaps', 'who knows?'

(209)E. ke patt-o akram ā-t-o hò-we

what information-NOM.M.SG Akram come-IMPFV-M.SG be-2/3sg

'Perhaps Akram will come.'

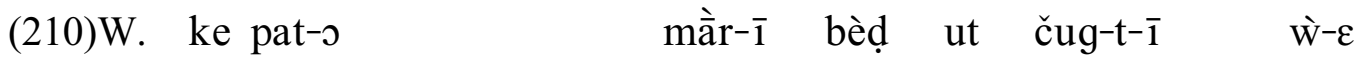
what information-NOM.M.SG 1pl.GEN-F sheep there graze-IMPFV-F be-2/3

'Perhaps our sheep will graze there.'

The Presumptive Habitual consists of the imperfective form of the verb followed by the unspecified form of /hò-/ 'be' and future auxiliary $/ \mathrm{k}-/(/ \mathrm{g}-/)$. It describes probable future actions or actions assumed to be in progress:

$$
\begin{aligned}
& \text { wó hà-t-o hò-we k-o } \\
& \text { 3sg.DIST.NOM.M come-IMPFV-M.SG be-2/3sg FUT-M.SG } \\
& \text { 'He will be coming.' }
\end{aligned}
$$

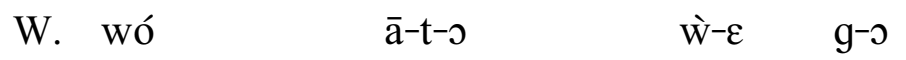

$$
\begin{aligned}
& \text { 3sg.DIST.NOM.M come-IMPFV-M.SG be-2/3 FUT-M.SG }
\end{aligned}
$$

Replacing imperfective forms with ones involving the continuous auxiliary /lag-/ (see below) results in ungrammatical constructions (cf. the Urdu Presumptive Continuous; Masica 1991:293). 
The Contrafactive Habitual consists of the negative /n $\frac{1}{1} /$ or /ná/ and the imperfective form of the main verb followed by the imperfective form of /hò-/ 'be'. Its functions include simple negations of the Present Habitual, as in (212), and describing verbal actions like that in (213) which could have but did not (or do not) transpire.

$$
\text { h⿳亠े⿵ } \quad \text { n⿳亠丷厂 } \quad \text { bes-t-o hò-t-o }
$$

1sg.NOM NEG sit-IMPFV-M.SG be-IMPFV-M.SG

'I don’t usually sit.'

(213)E. h̀ें kade it ná bes-t-o hò-t-o te min-nā 1sg.NOM if here NEG sit-IMPFV-M.SG be-IMPFV-M.SG then 1sg.OBL-DAT selān̄i sáī ná hò-t-ā tourist be.seen NEG be-IMPFV-M.SG 'If I didn't always sit here then I wouldn't see the tourists.'

The Presumptive Perfective consists of the perfective form of the verb followed by the unspecified form of /hò-/ 'be' and the future auxiliary $/ \mathrm{k}-/(/ \mathrm{g}-/)$. In the Eastern dialect, the perfective participle marker / $\mathrm{w}^{-} /$occurs optionally after the perfective form of the verb. I know of no difference in meaning between the examples in (214):

$$
\text { g-ī-o W-o hò-we k-o }
$$

3sg.DIST.NOM.M go-PERF-M.SG PFP-M.SG be-2/3sg FUT-M.SG

'He must have gone.'

b. wó

$$
\text { g-ī-o hò-we k-o }
$$

3sg.DIST.NOM.M go-PERF-M.SG be-2/3sg FUT-M.SG

'He must have gone.'

$$
\begin{array}{lllll}
\text { W. wó } & \mathrm{g}-\overline{1}-\mathrm{c} & \grave{\text { w}}-\varepsilon & \mathrm{g}-\mathrm{\jmath} \\
& \text { 3sg.DIST.NOM.M } & \text { go-PERF-M.SG } & \text { be-2/3 } & \text { FUT-M.SG }
\end{array}
$$

'He must have gone.' 
The Contrafactive Perfective consists of the perfective form of the main verb and the imperfective form of /hò-/ 'be'. It describes perfective verbal actions which, had they occurred, would have resulted in some other verbal action that did not occur. It is used only in the condition clause of conditional constructions:

(215)E. seāl mā min-nā ek xat mil-e-o hò-t-o

winter in 1sg.OBL-DAT one letter meet-PERF-M.SG be-IMPFV-M.SG

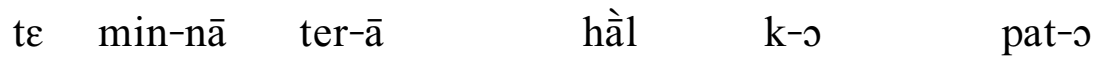

then 1sg.OBL-DAT 2sg.GEN-OBL.M.SG condition GEN-NOM.M.SG information

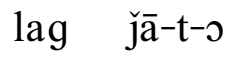

attach go-IMPFV-M.SG

'If I had received one letter during the winter, then I would have found out about your condition.'

(216)E. to ${ }^{\sim}$ kade $\overline{1} \mathrm{~d}$ apar ā-e-っ hò-t-o

2sg.NOM if Eid on come-PERF-M.SG be-IMPFV-M.SG

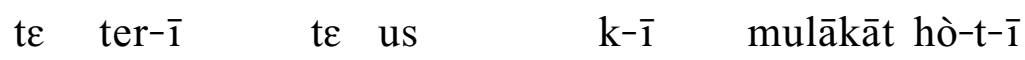

then 2sg.GEN-F.SG and 3sg.DIST.OBL GEN-F.SG meeting be-IMPFV-F.SG

'If you had come for Eid, you and he/she would have met.'

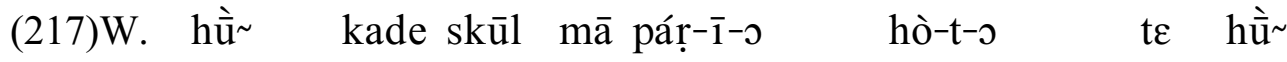

$1 \mathrm{sg} . \mathrm{NOM}$ if school in read-PERF-M.SG be-IMPFV-M.SG then $1 \mathrm{sg} . \mathrm{NOM}$

kite nokar hò-t-o

somewhere employee be-IMPFV-M.SG

'If I had studied in a school, I would be an employee somewhere.'

All such condition clauses can also be formed by the Unspecified Contrafactive (see

4.2.1.2.2) without change in meaning. 


\section{Constructions Involving the Continuous Auxiliary/lag-/}

The continuous auxiliary consists of a stem, /lag-/, and an AC suffix. Continuous aspect indicates that a specific verbal event has commenced and is ongoing at a specified past or present time. The stem of the continuous auxiliary, /lag-/, is the perfective form of the verb 'attach' (an original lexical meaning not applicable in many contexts). This form is irregular because it lacks the perfective aspect suffix /-e/ $(/-\overline{1} /)$. In Eastern, the continuous auxiliary often occurs in combination with the perfective participle marker $/ \mathrm{w}^{-}$ / (see 4.2.1.7). ${ }^{3}$ This $/ \mathrm{w}^{-} /$formative is normally omitted in Western (especially after /lag-/), and is optional in Eastern following /lag-/.

The Present Continuous consists of the verb stem with PC suffix followed by the continuous auxiliary /lag-/, the perfective participle marker /w-/ (in the Eastern dialect only), and optionally by the present auxiliary. It describes the verbal action as being in progress at the present time. Present Continuous verbal constructions cannot as such be negated. The negative counterpart of this construction is the Habitual (Negated) Unspecified Contrafactive (4.2.1.2.2).
(218)E. wó
bazār nā čal-e lag-o w-o
3sg.DIST.NOM.M bazaar DAT go-2/3sg CONT-M.SG PFP-M.SG
'He is going to the bazaar.'
W. wó bazār nā čal-e lag-o
3sg.DIST.NOM.M bazaar DAT go-2/3sg CONT-M.SG
'He is going to the bazaar.'




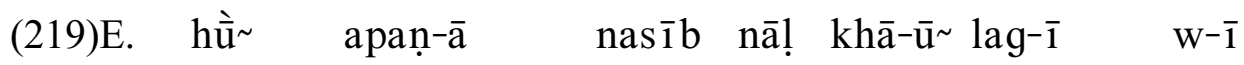

1sg.NOM REFL.OBL.M.SG fortune with eat-1sg CONT-F.SG PFP-F.SG

'I am eating by means of my own [good]fortune.'

(220)W. gidur age te kấḍ rič $\varepsilon, \quad \bar{a}-w \varepsilon \quad l a g-\bar{a}$ jackal ahead and behind bear PRES come-2/3 CONT-M.PL

'They are coming; the jackal in front and the bear behind [him].'

The Past Continuous consists of the verb stem with PC suffix followed by the past auxiliary /th-/, the continuous auxiliary / $\mathrm{lag}^{-/}$and the perfective participle marker $/ \mathrm{w}^{-/}$(in the Eastern dialect only). It describes the verbal action as being in progress simultaneous with another past verbal action in the discourse:

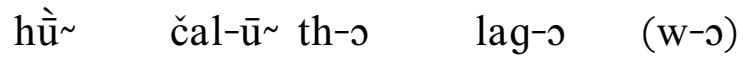

$$
\begin{aligned}
& \text { 1sg.NOM go-1sg PAST-M.SG CONT-M.SG (PFP-M.SG) }
\end{aligned}
$$

(222)E. te $\varepsilon^{\sim}$ jis waxt fon $\mathrm{k}-\overline{1}-\mathrm{o}$ te hàm roṭ- $\overline{1}$

2sg.AG REL.OBL.SG time phone do-PERF-M.SG and 1pl.NOM bread-F.SG

$\mathrm{kh}-\overline{\mathrm{a}} \sim$ th- $\overline{\mathrm{a}} \quad \operatorname{lag}-\overline{\mathrm{a}} \quad \mathrm{w}-\overline{\mathrm{a}}$

eat-1pl PAST-M.PL CONT-M.PL PFP-M.PL

'When you phoned we were eating.'

(223)W. (nān-o mer-o šinkīārī nā maternal.grandfather-NOM.M.SG 1sg.GEN-NOM.M.SG Shinkiari DAT ā-e-o.) kite taṇā te khū po muč dèn- $\overline{1}$ come-PERF-M.SG somewhere downhill and well on many woman-F bàr- $\varepsilon$ th $-\overline{1} \quad \operatorname{lag}-\overline{1}$ fill-2/3 PAST-F CONT-F

('My grandfather came to Shinkiari.) Somewhere below lots of women were filling water [vessels] at a well.' 
In the above examples, movement of the past auxiliary to the position following /lag- $\left(\mathrm{w}^{-}\right) /$is possible but unusual in discourse.

\subsubsection{Dialect-specific Finite Verbal Constructions}

The Contrafactive Conditional (Eastern only) is an alternative to the Unspecified Contrafactive in conditional constructions involving singular subjects (see the form of the Habitual (Negated) - Unspecified Contrafactive in 4.2.1.2.2). For first person singular, the Contrafactive Conditional consists of the unspecified form of the verb followed by the present auxiliary variant $/ \mathrm{h} \overline{\mathrm{a}} \sim$. It is used in both the condition and result clauses of the conditional construction. Compare its use in (224) with that of the Unspecified Contrafactive in (225) (the latter is obligatory for all contrafactive conditionals in Western):

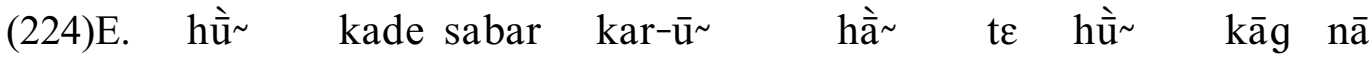
1sg.NOM if patience do-IMPFV-1sg 1sg.PRES then 1sg.NOM crow DAT mār $1 \overline{1}-\bar{u} \sim \quad h \bar{a} \sim$ hit take-1sg 1sg.PRES 'Had I been patient, I would have killed the crow.'

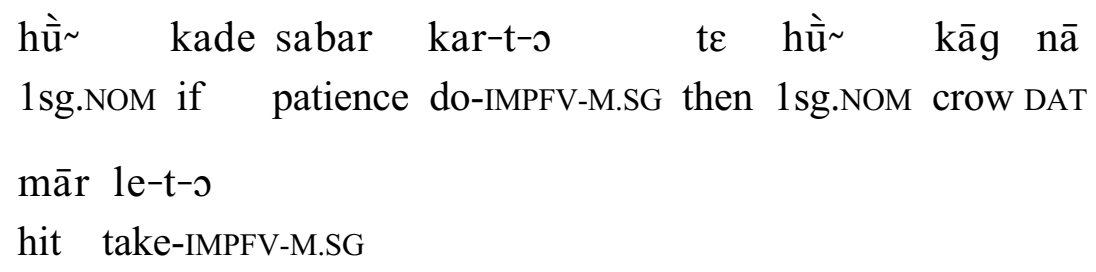

'Had I been patient, I would have killed the crow.'

For second and third person singular subjects, the result clause (only) may feature a perfective form of the verb consisting of the verb stem and the 'old' perfective suffix /-eā/. Compare its employment in (226) with that of the Unspecified Contrafactive in (227): 
(226)E. koe juíṛ-o swātī th-o, ó nokrī kar-eā INDEF.NOM.M.SG REL-NOM.M.SG Swati PAST-M.SG 3sg.DIST wage.labor do-PERF

'The one who was a Swati, he would be doing wage labor.'

(227)E. koe ǰír-o swātī th-o, ó nokrī

INDEF.NOM.M.SG REL-NOM.M.SG Swati PAST-M.SG 3sg.DIST wage.labor

kar-t-o

do-IMPFV-M.SG

'The one who was a Swati, he would be doing wage labor.'

The Present Continuous II (Eastern only) consists of the verb stem followed by the 'continuous II' auxiliary (itself the perfective form of /ré-/ 'stay') and the present auxiliary $/ \mathrm{h}-/(/ \varepsilon /)$. This construction describes intransitive verbal events and situations that are ongoing over an indefinite period of time that includes the present. It occurs only with select intransitive verbs including /hò-/ 'be' /guzar-/ 'pass', and /čal-/ 'go'. Although it is structurally identical to the Urdu and Punjabi present continuous constructions (and may represent a borrowing of the same), the function thereby achieved in those languages is achieved in Gojri by the Present Continuous (formed with /lag-/).

Consider these examples:

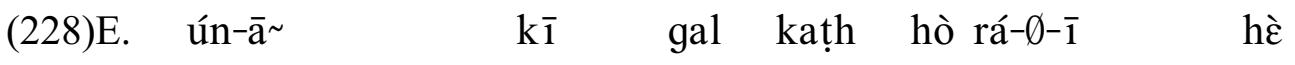
3pl.DIST.OBL-OBL.PL GEN-F.SG word stream be stay-PERF-F.SG 2/3sg.PRES 'They are engaged in discussions.' (lit. 'Their conversation is ongoing.') (229)E.

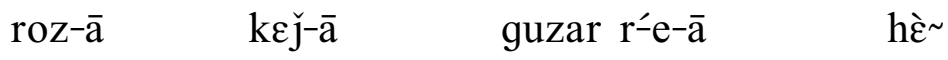
fast-NOM.M.PL how-NOM.M.PL pass stay-PERF-M.PL 3pl.PRES 'How are the fasts going?' 


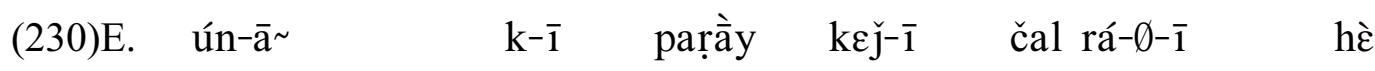
3pl.DIST.OBL-OBL.PL GEN-F.SG education how-F.SG go stay-PERF-F.SG 2/3sg.PRES 'How is their education coming along?'

The Present Continuous II is negated by the insertion of the particle $/ \mathrm{n} \frac{\dot{1}}{\mathrm{i}} /$ before the verb and removal of the present auxiliary:

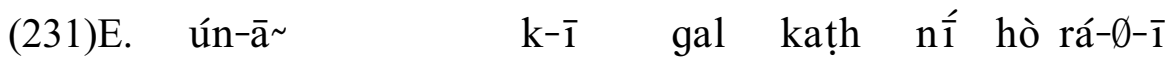

3pl.DIST.OBL-OBL.PL GEN-F.SG word stream NEG be stay-PERF-F.SG

'They are not engaged in discussions.' (lit. 'Their conversation is not ongoing.')

The Past Continuous II (Eastern only) consists of the verb stem followed by the continuous II auxiliary and the past auxiliary /th-/. It locates select continuous verbal events and situations in past time:

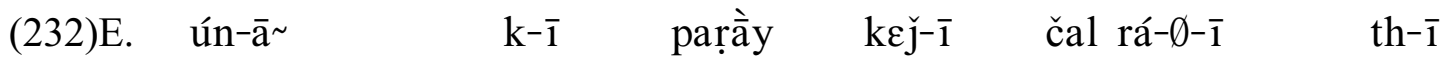
3pl.DIST.OBL-OBL.PL GEN-F.SG education how-F.SG go stay-PERF-F.SG PAST-F.SG 'How was their education coming along?'

The Contrafactive Continuous II (Eastern only) consists of the verb stem followed by the continuous II auxiliary and the imperfective form of /hò-/ 'be'. It describes continuous actions and events that could transpire but do not. In Western, all such notions are expressed by means of the Contrafactive Perfective (see 4.2.1.2.5).

(233)E. wó hò hò-t-o

3sg.DIST.NOM.M come stay-PERF-M.SG be-IMPFV-M.SG then

maz-o hò-t-o

enjoyment-NOM.M.SG be-IMPFV-M.SG

'If he was coming then it would be a good time.' 
The verb phrase in the first clause of (233) encodes a composite of the verbal notions expressed in (234):

(234)E.a. wó āwe lago wo 'He is coming.'

b. wó n⿳亠丷厂 āto 'He isn't coming.' / 'He doesn't come.'

The Present Unspecified (Western only) consists of the verb stem with PC suffix followed by the present auxiliary $/ \mathrm{h}-/(/ \varepsilon /)$. Use of this form typically indicates that the subject is about to commence upon a course of action. It occurs only with first singular subjects in my data:

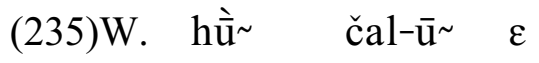

1sg.NOM go-1sg PRES

'I am going.'

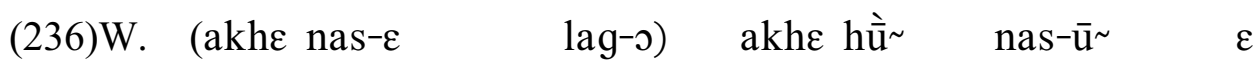

QUOT run.away-2/3 CONT-M.SG QUOT 1sg.NOM run.away-1sg PRES

('Are [you] escaping?') '[Yes,]I am going to escape.'

In (237), however, the meaning is different than in the above examples:

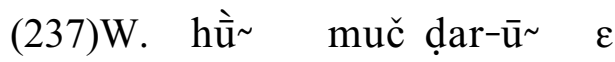

1sg.NOM very fear-1sg PRES

'I am very afraid.'

The Present Unspecified does not occur in the Eastern dialect, at least not in that spoken in Pakistan proper. This may be due to the correspondence of the Eastern present auxiliary vowels with the PC vowels on the verb. Sharma, however, reports such a construction for Punch-Rajauri Gojri: /tũ kıt ré è/ 'Where do you live?' (1982:100; transcription his). 
Instead, Eastern Gojri approximates the function of the Western Present Unspecified by means of a little-employed strategy involving the perfective form of the verb and an optional present auxiliary:

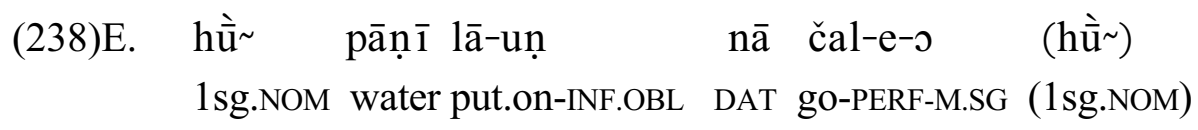

'I am going to water [the fields].'

Example (238) is a translation of one of Sharma's examples, /hũ paṇi laṇ čəlyo ã̀/ (1982:191; transcription and English gloss his). My research assistants say that the nuance is identical to that in examples (235) and (236) above.

\subsubsection{Passives}

There are several means of forming passive constructions in Gojri. The most common strategy employs / $\mathrm{j} \overline{\mathrm{a}}-/$ 'go' as the conjugational base, together with the perfective form of the active verb. The latter agrees with the patient in gender and number. This type of construction occurs with or without an agent marked by the ablative postposition/te/:

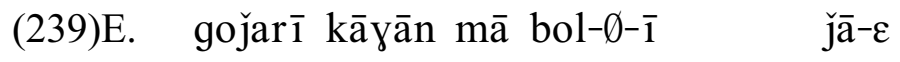

Gojri Kaghan in speak-PERF-F.SG go-2/3sg

'Gojri is spoken in Kaghan.'

(240)W. ajaṛ $\overline{1}$ te bè $\operatorname{katr}-\varnothing-\overline{1}$ jāa $\varepsilon$ th- $\overline{1}$ shepherd from sheep shear-PERF-F go-2/3 PAST-F

'The sheep were sheared by the shepherd.'

In passive constructions of this type, select verbs including /mār-/ 'kill' and /khā-/ 'eat' necessarily feature the passive suffix /-e/ $(/-\overline{1} /)$ on the active verb in place of the usual perfective aspect and AC suffixes. This passive suffix is indistinguishable from the perfective aspect suffix, although it derives from a separate source (Masica 1991:316). 
Evidence that the suffix is invariable for all genders and numbers is shown in (241)-(243).
(241)E.
$\begin{array}{lll}\text { ek lel-っ } & \text { khā-e } & \text { g-ī-o } \\ \text { one lamb-NOM.M.SG } & \text { eat-PASS } & \text { go-PERF-M.SG }\end{array}$
'One ram was eaten.' (cf. the ungrammatical equivalent/*ek lelı khāe g gīo/)
(242)E. do jạn-ā mār-e g-ī-ā
two man-NOM.M.PL kill-PASS go-PERF-M.PL
'Two men were killed.'

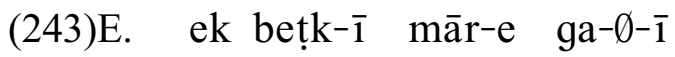
one girl-F.SG kill-PASS go-PERF-F.SG
'One girl was killed.'

In the above examples, replacing the verb and passive suffix with the perfective form of the verb results in ungrammatical forms.

Another passive strategy features the unspecified form of /hò-/ 'be' as the conjugational base, following the oblique infinitive of the active verb and an agent marked by the ablative postposition /te/:

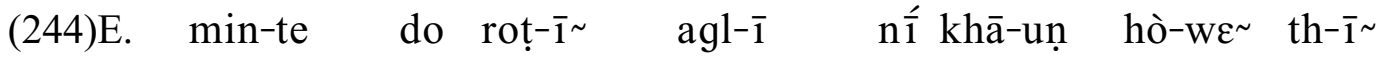 1sg.OBL-ABL two bread-F.PL former-F.SG NEG eat-INF.OBL be-3pl PAST-F.PL 'Weren't two pieces of bread being eaten by me before?'

A third strategy, which should perhaps be called an impersonal construction rather than a true passive, employs the third person plural Unspecified Habitual of the active verb (cf. 4.2.1.2.1) with no expressed agent:
(245)E. is
š $\varepsilon \quad n \bar{a}$ ke $\quad k^{\prime} \varepsilon^{\sim}$
3sg.PROX.OBL thing DAT what say-3pl
'What is this thing called?' 


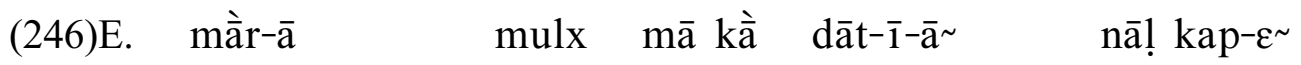

1pl.GEN-NOM.M.SG country in grass sickle-F.SG-OBL.PL with cut-3pl

'In our country grass is cut with sickles.'

(247)W. čāwal dái nạ khā-

rice yogurt with eat- $2 / 3$

'Rice is eaten with yogurt.'

\subsubsection{Causatives}

Causative verbal stems are produced by adding the causative suffix $/-\overline{\mathbf{a}} /$ to verbal roots. We may therefore summarize the structure of the Gojri verbal stem as follows:

$$
\text { ROOT - (CAUS) }
$$

That is, a stem may consist of a root plus an optional causative suffix. Some examples of bare root/causative verbal pairs are shown in (249):

\begin{tabular}{|c|c|c|c|c|}
\hline /badal-/ & intrans. 'change' & $>$ & /badlā-/ & 'change' \\
\hline$/ \overline{\mathbf{j}} \overline{1}-/$ & 'live' & $>$ & $/ / \bar{j} \bar{i} \bar{a}-/$ & 'resurrect' \\
\hline /pak-/ & 'ripen’ & $>$ & /pakā-/ & 'cook' \\
\hline /kar-/ & 'do’ & $>$ & /karā-/ & $\begin{array}{l}\text { 'make } \\
\text { arrangements' }\end{array}$ \\
\hline /suñ-/ & 'listen' & $>$ & /suṇā-/ & 'tell' \\
\hline /čal-/ & 'go' & $>$ & /čalā-/ & 'send' \\
\hline
\end{tabular}

A variant of the causal suffix, $/$-ạ $/ /$, occurs with the causative member of the pairs in (250).

$$
\begin{array}{lllll}
\text { /brs-/ } & \text { 'sit' } & > & / \text { besīà̀l-/(/besà̀ } 1 /) & \text { 'seat' } \\
\text { /so-/ } & \text { 'sleep' } & > & \text { /swal }-/ & \text { 'put down to sleep' }
\end{array}
$$




\begin{tabular}{|c|c|c|c|c|}
\hline /khā-/ & 'eat' & $>$ & /khwāḷ-/ trans. & 'feed' \\
\hline$/ \mathrm{p} \overline{\mathbf{1}}-/$ & 'drink' & $>$ & /p̄̄āl-/ & 'give to drink' \\
\hline
\end{tabular}

Causative verbs are also formed by lengthening the short vowel of another verb. Some representative examples are given in (251):

\begin{tabular}{|c|c|c|c|c|}
\hline /mur-/ intrans. & 'return' & $>$ & /mor-/ trans. & 'return' \\
\hline /ṭur-/ & 'walk' & $>$ & /ṭor-/ & 'drive [livestock]' \\
\hline /kar-/ intrans. & 'boil' & $>$ & /kāṛ-/ trans. & 'boil' \\
\hline /čimur-l & 'cling to' & $>$ & /čimer/ & 'place against' \\
\hline /mar-/ & 'die' & $>$ & /mār-/ & 'kill, hit' \\
\hline /nikhar-/ intran & 'separate' & $>$ & /nikher-/ trai & 'separate' \\
\hline
\end{tabular}

While Sharma reports for Punch-Rajauri Gojri numerous second causatives formed by adding another $/-\bar{a} /$ suffix to a causative stem already suffixed with $/-\bar{a} /$ (resulting necessarily in the suffix /-wā/ after hiatus resolution), my research assistants insist that they are not used in any form of Gojri with which they are familiar. I do, however, have examples of second causatives involving pairs of stems related like those in (252) with the transitive (or causative) member taking the causative suffix:

(252)a. /čár-/ 'be built' /čârrel 'build'

/čarà̀-/ 'have built' (i.e. 'arrange for the construction of')

b. /mar-/ 'die'

/mār-/ 'hit, attack, kill'

/marā-/ 'kill' (i.e. 'arrange for the death of') 


\subsubsection{Conjunct Verbs}

Gojri has produced numerous verbs by joining a noun or adjective with a semantically empty or weakened verb which serves as the conjugational base. Stems most commonly employed in such compounds include /kar-/ 'do', /hò-/ 'be', /mār-/ 'hit', /le-/ 'take', /de-/ 'give', /ā-/ 'come', and /lā-/ 'put on'. Some examples are /bāz ā-/ ' repent', /čuylī mār-/ 'start a fight', and /gal kar-/ 'talk'. Conjunct verbs involving the verb stems /le-/ 'take' and /de-/ 'give' are more likely to retain more of the verb's independent semantic content. For example, consider /báḍ̄i le-/ 'take bribes' and /nāto de-/ 'give in marriage'.

Many transitive and intransitive pairs of Gojri verbs feature a constant noun or adjective conjoined to /kar-/ 'do' and /hò-/ 'be', respectively. Examples include /baṭlā hò-/ 'be gathered' and /baṭlā kar-/ 'gather', and /bideā hò-/ 'be bidden farewell' and /bideā kar-/ 'bid farewell' (Western forms have /bidīāa 'farewell').

All Gojri conjunct verbs are lexicalized; i.e. the combinations are fixed and must be memorized, and attempts to substitute for either constituent result in ungrammatical forms.

\subsubsection{Non-finite Verb Forms}

Prototypical non-finite or dependent verb forms are those verbs which modify the main verb and are not fully inflected such that they can stand alone in discourse. Payne (1997:306) states that verbs are dependent to various degrees, or conversely, that they are finite to various degrees. Understanding finiteness as a continuum is particularly useful in the case of Gojri and other Indo-Aryan languages, where originally non-finite forms like the imperfective and perfective participles have been incorporated fully into the finite verbal paradigm (Masica 1991:321). Gojri participles are not fully inflected (i.e. they 
lack PC suffixes), yet in certain constructions they can stand alone as the main verb (see 4.2.1.1). In other constructions, as we shall now see, they serve as dependent modifiers of another main verb.

The structure of the non-finite verb is shown in (253): STEM - SUFFIX - (CONCORD)

In other words, a non-finite verb consists of a verbal stem with suffix, followed optionally by a concord suffix.

Non-finite forms in Gojri perform a wide range of nominal, adjectival, and adverbial functions (Masica 1991:321). I now describe infinitives, adjectival participles, adverbial participles, and conjunctive participles.

Infinitives $>\mathrm{V}$-ing / to $\mathrm{V}$

Gojri infinitives perform a variety of nominal functions. They are formed by adding an infinitive suffix to the verb stem. Nominative case infinitives consist of a verb stem followed by the suffix /-ñ / and an AC suffix. The infinitive suffix /-n $/$ changes to /-n/ when attached to verbs ending in a retroflex consonant. The nominative case infinitive may function as the subject of experiencer constructions like (254) or of predicate nominal constructions like (255). It agrees in gender and number with the associated noun. Infinitives are always masculine singular when there isn't an associated noun:

(254)W. sel kar-ṇ-o man-nā čang-o lag- $-\varepsilon$ outing do-INF-NOM.M.SG 1sg.OBL-DAT nice-NOM.M.SG attach-2/3

'I like to travel.'

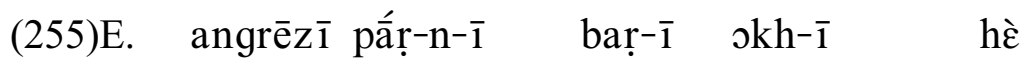

English read-INF-F.SG big-F.SG difficult-F.SG 2/3sg.PRES

'Reading English is very difficult.' 
Oblique case infinitives consist of a verb stem followed by the suffix /-un/ with no AC suffix. The oblique infinitive is used adjectivally with the genitive to modify nouns, ascribing to the noun the characteristic of agency:

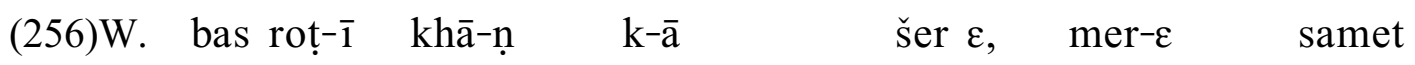
stop bread-F eat-INF.OBL GEN-M.PL.NOM lion PRES 1sg.GEN-LOC together '[They] are only lionhearted when it comes to dining, myself included.' (lit. '[They] are lions only of food-eating, myself included.')

The oblique infinitive is also used with the postpositions /nā/, /dar/ (/tā/) and /wāste/ in purpose clauses:

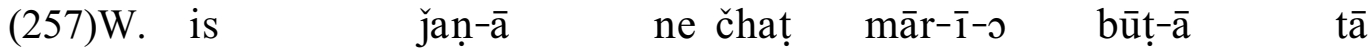
2sg.PROX.OBL man-OBL.M.SG AG grabbing hit-PERF-M.SG tree-OBL.M.SG toward nap-un tā catch-INF.OBL toward

'This man grabbed at the tree to catch hold of it.'

Sometimes the postposition is omitted from the purpose clause without any change in meaning:

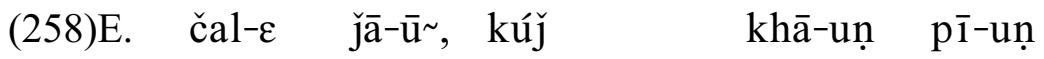
go-2/3sg go-1sg INDEF.NOM.PL eat-INF.OBL drink-INF.OBL

'I should go eat and drink a little.'

The remaining uses of the infinitive are described in 4.1.5 and 4.2.2.2.

$\underline{\text { Perfective Adjectival Participle }>\text { has been V-ed }}$

Perfective participles consist of the verb stem followed by the perfective aspect suffix $/-\mathrm{e} /(/-\overline{1} /)$ and an AC suffix. In the Eastern dialect they are commonly marked by a following /w-/ formative (= 'perfective participle marker'), which takes an AC suffix. 
The nominative perfective participle functions adjectivally, ascribing to the modified noun a characteristic which has resulted from a prior verbal action. It is therefore the semantic equivalent of the English perfect 'tense'. Most commonly it occurs in simple attributive clauses, and it agrees with the modified noun:

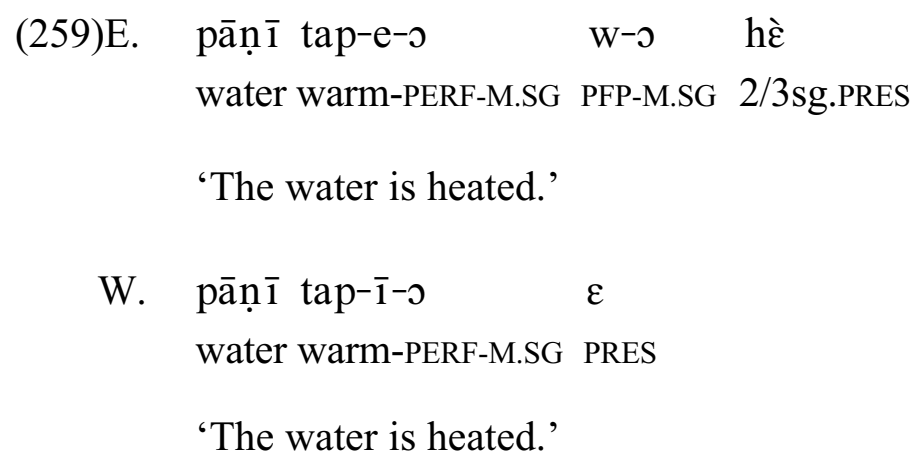

Perfective adjectival participles can also convey important nuances of meaning in sentences like those in (262)-(264): 


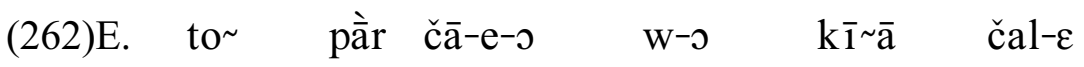
2sg.NOM load lift-PERF-M.SG PFP-M.SG to.where go-2/3sg 'Where are you going with that load you are carrying?'

(263)E. me to $\sim$ it $\overline{\mathrm{a}}-\mathrm{e}-\mathrm{0}$ w-0 hèr-e-5

1sg.AG 2sg.NOM here come-PERF-M.SG PFP-M.SG see-PERF-M.SG

'I saw you [after you had] arrived.'

(264)E. me akram sad-e-o w-o hè

1sg.AG Akram call-PERF-M.SG PFP-M.SG 2/3sg.PRES

'I have called Akram [and he has arrived].' (cf. the Present Perfective in (188))

Perfective Adverbial Participle $>$ since V-ing ...

Perfective participles inflected for oblique case preceding the dative postposition $/ \mathrm{n} \bar{a} /$ are used to indicate that a period of time has elapsed since an earlier action or event. Note that the Western example employs the perfect participle marker $/ \mathrm{w}-/$, which is omitted elsewhere in that dialect:

(265)E. min-nā it $\bar{a}-\mathrm{e}-\overline{\mathrm{a}} \quad \mathrm{w}-\overline{\mathrm{a}} \quad$ nā do kànț-ā 1sg.OBL-DAT here come-PERF-OBL.M.SG PFP-OBL.M.SG DAT two hour-NOM.M.PL

lag $g-\overline{1}-\bar{a}$

attach go-PERF-M.PL

'Two hours have passed since I arrived here.'

(266)E. xat kàl-e-āa nā ek mìn-o

letter pour-PERF-OBL.M.SG PFP-OBL.M.SG DAT one month-NOM.M.SG

hò $\mathrm{g}-\overline{1}-\mathrm{\jmath}$

be go-PERF NOM.M.SG

'A month has passed since the letter was mailed.' 


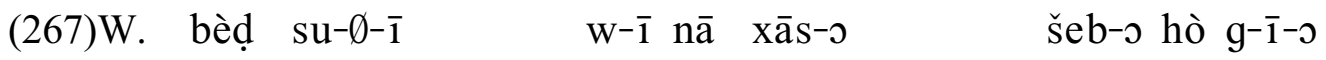

sheep give.birth-PERF-F PFP-F DAT special-NOM.M.SG period be go-PERF-M.SG

'It has been quite a while since the sheep gave birth.'

Imperfective Adjectival Participles $>$ V-ing ...

Imperfective participles consist of the verb stem followed by the imperfective aspect suffix /-t/ and another suffix, most commonly an AC suffix.

Imperfective participles taking the nominative $\mathrm{AC}$ suffixes are adjectival. They agree in gender and number with the modified nominative subject (as in (268)) or object (in ergative constructions like (269) and (270)):

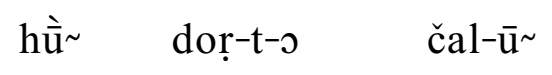

1sg.NOM run-IMPFV-M.SG go-1sg

'I go running.' (i.e. 'I run as I go.')

(269)E. me to $\varepsilon^{\sim}$ kam kar-t-o hèr-e-o

1sg.AG 2sg.NOM work do-IMPFV-M.SG see-PERF-M.SG

'I saw you working.'

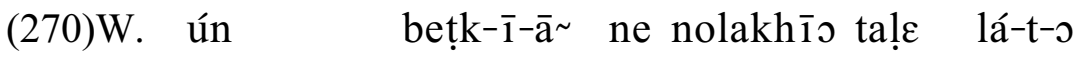

3pl.DIST.OBL girl-F-OBL.PL AG Nolakhio down descend-IMPFV-M.SG

dekh- $\overline{1}-0$

see-PERF-M.SG

'Those girls saw Nolakhio going down.'

Imperfective Adverbial Participles > while V-ing, etc.

Imperfective participles inflected for oblique case preceding a postposition function adverbially.

When preceding the dative postposition /nā/, they describe circumstances or actions attending the main verbal action: 


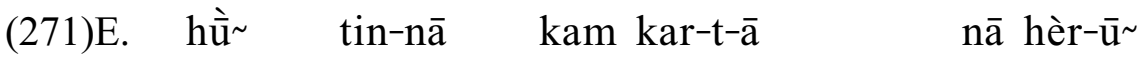

1sg.NOM 2sg.OBL-DAT work do-IMPFV-OBL.M.SG DAT see-1sg

lag-o W-o

CONT-M.SG PFP-M.SG

'I am watching you while you are working.'

If the participle in (271) was not so inflected by /nā/ (i.e. if the form was /kar-t-ə/), then the meaning would be 'I am watching you while I am working.'

When preceding the locative postposition /mā/ 'in', imperfective adverbial participles indicate an action within the progression of which the main verb transpires:

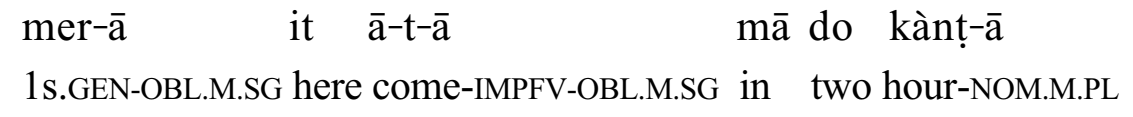

lag $g-\overline{1}-\bar{a}$

attach go-PERF-M.PL

'Just now it took two hours for me to get here.'

(273)W. man-nā kitāb pár-t-ā mā baṛ-o maz-o

1sg.OBL-DAT book read-IMPFV-OBL.M.SG in big-NOM.M.SG enjoyment-NOM.M.SG

$\overline{\mathrm{a}}-\mathrm{e}-\mathrm{\jmath}$

come-PERF-M.SG

'I really enjoyed reading the book.'

Imperfective adverbial participles inflected for locative case also describe the timing of the main verb with reference to another verbal action:

$$
\begin{array}{ll}
\text { nàte waxt } & \text { 'at bathing time' } \\
\text { čalte waxt } & \text { 'when it is time to go' } \\
\text { khāte waxt } & \text { 'at meal time' } \\
\text { milte waxt } & \text { 'when meeting' }
\end{array}
$$




\section{$\underline{\text { Repeated Adverbial Participles }}$}

Imperfective adverbial participles may also be formed with the suffix $/-\overline{\mathrm{a}} \sim /(/-\mathrm{e} \sim /)$, which is invariable for all genders and numbers. A common use of this type of adverbial participle is to describe continuous and repeated action associated with the main verb. In such cases the participle is always repeated at least once:

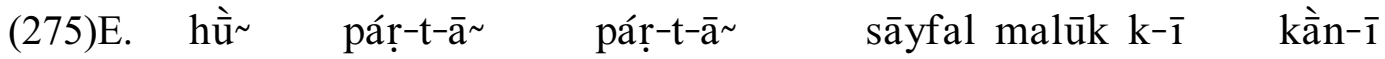

1sg.NOM read-IMPFV-ADV read-IMPFV-ADV Saiful Maluk GEN-F.SG story-F.SG

tuṝ póčh g-ī-o

up.to arrive go-PERF-M.SG

'I read and read and [finally] got to the story of Saiful Maluk.'

(276)E. thoṛ-o thoṛ-o kam kar- $-\mathrm{t}-\overline{\mathrm{a}} \sim$ kar- $-\mathrm{t}-\overline{\mathrm{a}} \sim$ te

a.little-NOM.M.SG a.little-NOM.M.SG work do-IMPFV-ADV do-IMPFV-ADV and

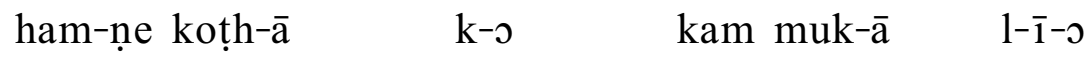

1pl-AG house-OBL.M.SG GEN-NOM.M.SG work finish-CAUS take-PERF-M.SG

'We did a little work here and did a little work there and finally we finished the work on the house.'

(277)W. mār-t-e mār-t-e de nā mār ke mōr-ā mā

hit-IMPFV-ADV hit-IMPFV-ADV giant DAT hit CP hole-OBL.M.SG in

$\overline{\mathrm{a}} \quad \mathrm{g}-\overline{\mathrm{i}}-\mathrm{\jmath}$

come go-PERF-M.SG

'Striking and striking, he killed the giant and came into the cavern.'

Such participles of the verbs 'go' and 'do' often occur without any other verb to describe continuous and repeated action (traveling or effort of some kind, respectively) performed over an indefinitely long period of time: 
(278)W. čār hò $\mathrm{g}-\overline{1}-\bar{a}$. čal-t-e čal-t-e ${ }^{\sim}$ čal-t-e čal-t-e four be go-PERF-M.PL go-IMPFV-ADV go-IMPFV-ADV go-IMPFV-ADV go-IMPFV-ADV 'Then there were four. (They) traveled and traveled and traveled and traveled.' A participle so formed may contract with the emphatic particle $/ \mathrm{h} \overline{\mathbf{1}} /$ to express an attendant action simultaneous to the main verb:

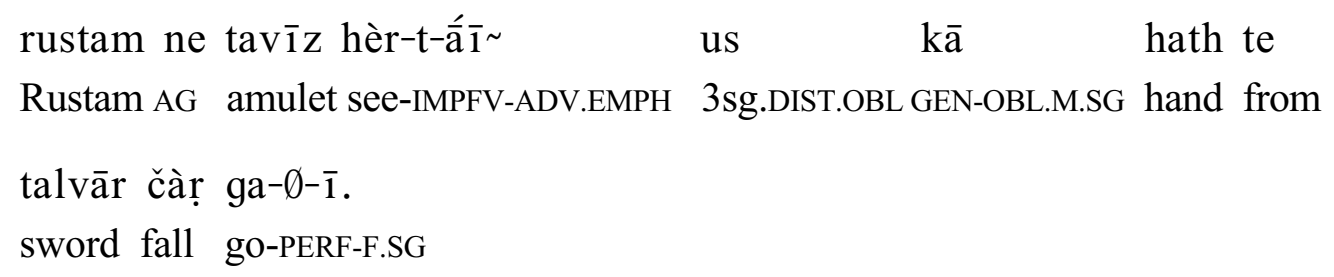

'Right when Rustam saw the amulet, his sword fell out of his hand.'

The contraction of this suffix /- $\overline{\mathrm{a}} /$ with $/ \mathrm{h} \overline{\mathrm{i}} /$ causes the low-tone inducing initial $/ \mathrm{h} /$ to become a high-tone inducing final $/ \mathrm{h} /$, with the nasalization of the suffix extending through the remaing vowel $/ \overline{1} /$. The Western variant of the participle in (279) is /hèrté $\overline{1} \sim /$ per the same contraction process, and the Urdu equivalent is /dekte $h \overline{1} /$. This contraction is obligatory, but speakers are capable of detaching the emphatic particle when asked to do so, in which case its pronunciation is $/ \mathrm{h} \overline{\mathrm{i}} /$ with low tone, as elsewhere.

Identical in function but formally unique are Eastern adverbial participles formed with the suffix $/-\overline{1} \sim /$ joined directly to the verb stem. This suffix remains unchanged for all persons and numbers, but may have grammaticalized from the feminine plural perfective participle. In (280), the sequence /la $\overline{1} \sim$ la $\overline{1} \sim /$ 'taking and taking' is equal in meaning to /le čaltā $~$ le čaltā $/:$ 


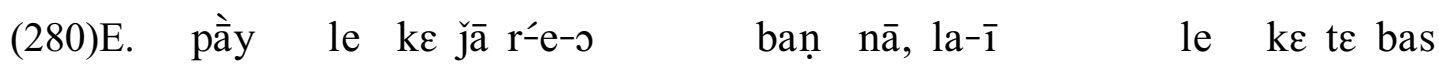
brother take CP go stay-PERF-M.SG forest DAT take-PERF-ADV take CP and well la- $\overline{1} \sim \quad l a-\overline{1} \sim \quad$ le $\quad k \varepsilon$ take-ADV take-ADV take CP

'The brother took [her] and left for the forest, taking [her] and well, took [her] on and on ...'

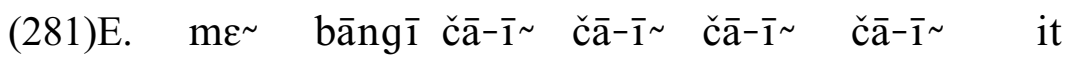
1sg.AG rooster lift-ADV lift-ADV lift-ADV lift-IMPFV here

āṇ $\quad k \varepsilon$ čhor ditt-o

bring CP leave give.PERF-M.SG

'I carried and carried the rooster - brought it here and left it.'

Western Gojri uses the repeated perfective participle in ergative constructions like that in (282). Note that the participles agree with the nominative object:

(282)W. me bāngī čā-e-

1sg.AG rooster lift-PERF-M.SG lift-PERF-M.SG lift-PERF-M.SG

čā-e-o it ạn ke čhợ dìtt-o.

lift-PERF-M.SG here bring CP leave give.PERF-M.SG

'I carried and carried the rooster - brought it here and left it.'

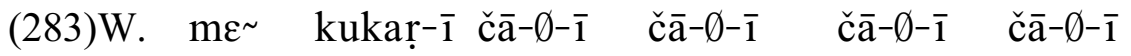

1sg.AG chicken-F lift-PERF-F lift-PERF-F lift-PERF-F lift-PERF-F

it ān ke čhoḍ ditt-̄i.

here bring $\mathrm{CP}$ leave give.PERF-F

'I carried and carried the chicken - brought it here and left it.'

My Eastern-speaking research assistant says that sometimes the suffix is $/-\overline{1} /$ rather than $/-\overline{1} \sim /$ in speech of his type. 
Conjunctive Participle > having V-ed ...

The conjunctive participle consists of the verb stem followed by the particle / $\mathrm{k} \varepsilon /$ (which happens to be phonetically identical with the locative postposition). Against the analysis of $/ \mathrm{k} \varepsilon /$ as a suffix is the fact that, although it always and only occurs immediately following a verb stem, it never undergoes phonological change in any environment and it attaches only to the final verb stem in a series of verb stems (including echo-formatives beginning with $/ \mathrm{s}^{-} /$'and the like', which elsewhere receive the same inflection as the main verb):

$$
\begin{aligned}
& \text { ṭur țur } \mathrm{k} \varepsilon \quad \text { 'having walked and walked ...' } \\
& \text { mang (šang) } k \varepsilon \quad \text { 'having begged (and such) ...' } \\
& \text { udīk kar kar ke 'having waited and waited ...' }
\end{aligned}
$$

The conjunctive participle immediately precedes the main verb phrase and describes an action completed immediately prior to the main verb.

$$
\begin{array}{lll}
\text { khā } & \text { ke } & \text { čal } \\
\text { eat } & \text { CP } & \text { go }
\end{array}
$$

'Having eaten, go!' / 'Eat and then go!'

In common idioms meaning 'give' and 'take with/away', $/ \mathrm{k} \varepsilon /$ is omitted. The absence of $/ \mathrm{k} \varepsilon /$ after the first verb stem in (286) and (287) makes these stem-on-stem constructions look like the vector constructions described in 4.2.2.1:

$$
\begin{aligned}
& \text { kāk-ā nā pes-ā } \quad \text { čā dé } \\
& \text { paternal.uncle-OBL.M.SG DAT money-NOM.M.PL lift give } \\
& \text { 'Give the money to Uncle!' (lit. 'Lifting the money, give it to Uncle.') }
\end{aligned}
$$




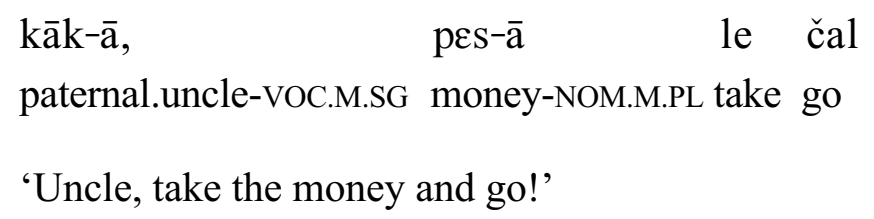

The conjunctive participle can be used to describe action that is repeated and continuous, by repeating the verb stem a number of times prior to $/ \mathrm{k} \varepsilon /$, as in (288):

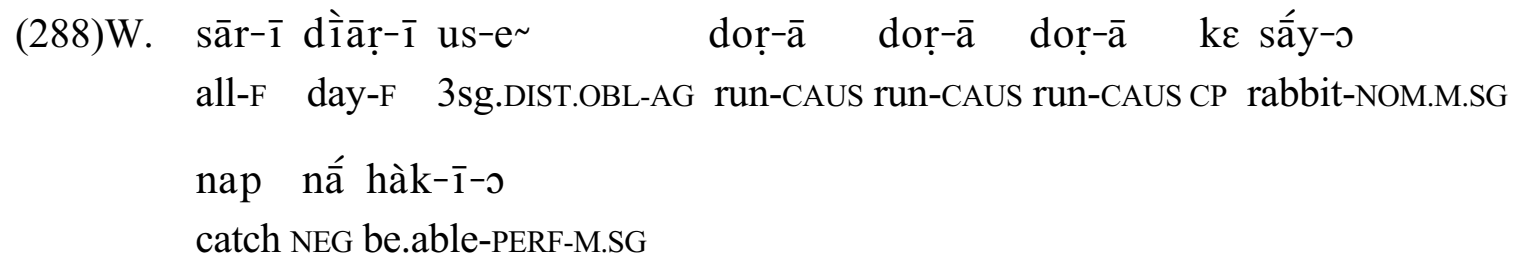

'All day he chased and chased and chased, but he wasn't able to catch the rabbit.'

Occasionally in narrative discourse $/ \mathrm{k} \varepsilon /$ is omitted altogether in such a construction, and the conjunctive participle serves as the main verb:

(289)W. age de kấṛ nolakhīo, doṛ doṛ doṛ dọ̣ ahead giant behind Nolakhio run run run run

'The giant was in front and Nolakhio was behind. (They) ran and ran and ran and ran.'

\subsubsection{Complex Verbs}

\subsubsection{Vector Verbs}

A small set of Gojri verbs occurs in compound with other verbs so as to intensify their meanings in some way. These 'vectors' follow the bare stem of another verb and receive whatever inflectional suffixation that verb would otherwise receive, while losing their own lexical meanings. With few exceptions, the vector verb can be removed without effecting any change in meaning. Their presence may specify a nuance of completeness, deliberateness, or benefaction to the manner of the verbal action (Masica 1991:326). 
They may also be preferred for aesthetic reasons. As noted by Masica for other IndoAryan languages, Gojri vectors also occur most commonly in perfective and imperative constructions, and less commonly with the future (1991:327). I now consider each of the vector verbs in turn.

/jā-/ 'go' occurs with select intransitive verbs including come, sit, sleep, be made, become, be, and open. This verb is irregular in the perfective, where the stem is $/ \mathrm{g}-/$ (see Appendix C). Its use conveys a nuance of completeness:

(290) bes jāa

sit go

'Sit down!'

(291) rič $\bar{a} \quad g-\overline{1}-0$

bear come go-PERF-M.SG

'A bear came.'

(292) wó ț̣īk hò $\mathrm{g}-\overline{1}-\mathrm{T}$

3sg.DIST.NOM.M well be go-PERF-M.SG

'He got better.'

(293)E. hàt lā- $\bar{u} \sim$ te jandar-o lug-o khūl jā- $-\varepsilon$

hand put.on-1sg then lock-NOM.M.SG free-NOM.M.SG open go-2/3sg

'When I put my hand on, the lock opens by itself.'

(294)W. wó amīr bán jāā- $\mathrm{g}^{-0}$

3sg.DIST.NOM.M wealthy be.made go-2/3 FUT-M.SG

'He'll become a wealthy man.'

/ré-/ 'stay' occurs with select intransitive verbs including come, go, sit, and sleep, and conveys a nuance of completeness similar to that noted for $/ \mathrm{j} \overline{\mathrm{a}}-/$ ' $\mathrm{go}$ '. The two vectors 
are apparently interchangeable in (295) and (296), but not in (297) and (298) or in (299) and (300) (where /jā-/ 'go' is not a vector):

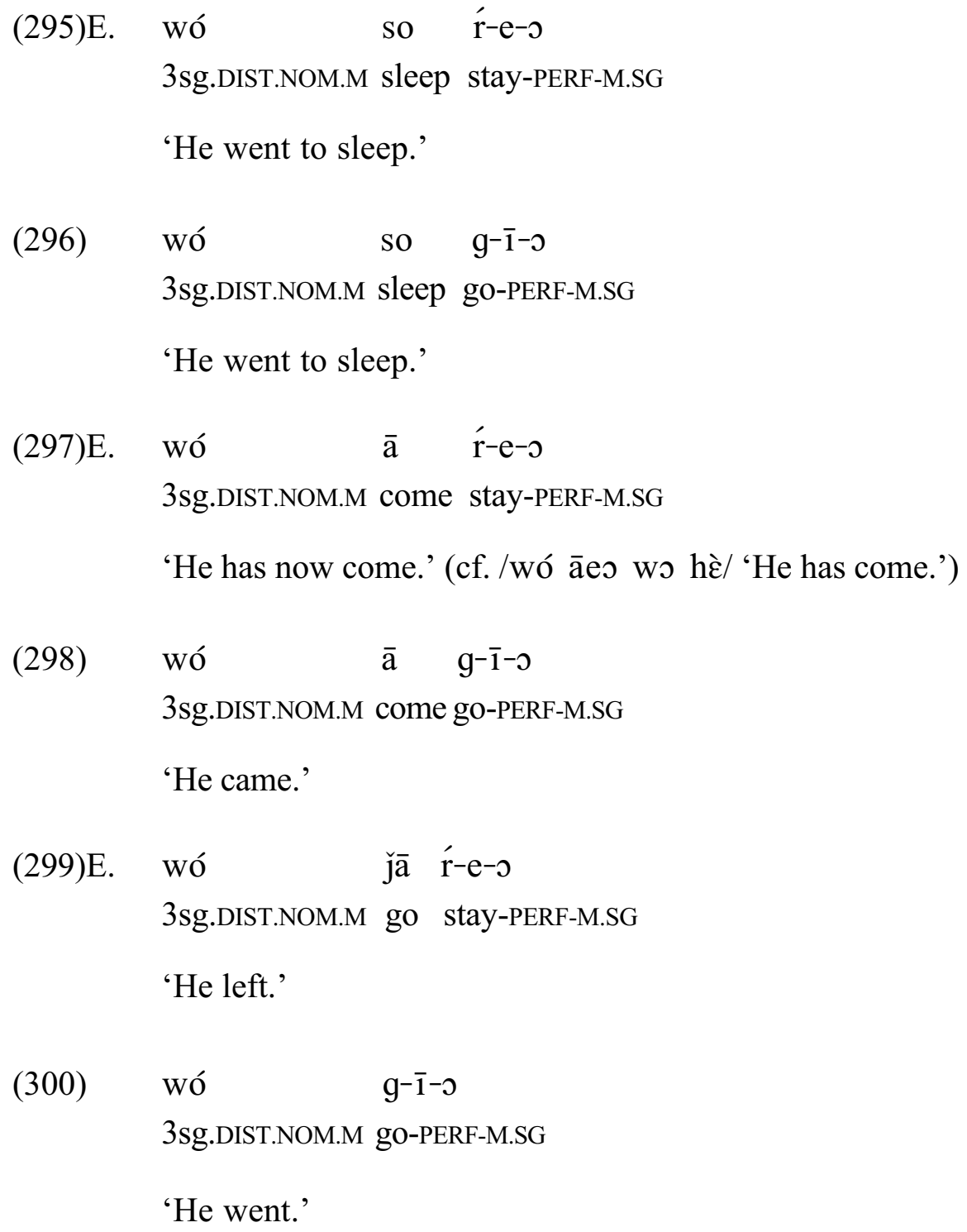

A common idiom meaning 'will depart' uses this kind of construction, but with the imperfective form of the second verb. In (301) the structure would predict habitual aspect (see 4.2.2.3 below), but the meaning is clearly not habitual here (perhaps by analogy to (299) above). Compare the construction in (301) with an ordinary use of this vector in the future in (302): 
(301)E. akram čal-t-o $\quad$ r- $-\varepsilon \quad k-0$

Akram go-IMPFV-M.SG stay-2/3sg FUT-M.SG

'Akram will leave [for an indefinitely long period].'

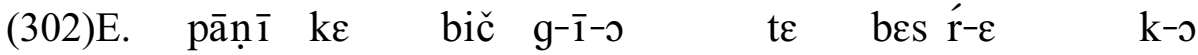
water GEN-LOC in go-PERF-M.SG then sit stay-2/3sg FUT-M.SG

'When it goes into water it will sit down.'

/čhur-/ 'drop' occurs with transitive verbs. This common vector occurs with most transitive verbs in certain contexts, but not with an as-yet-undefined class of verbs that includes 'deceive' and 'take care of'. The use of this vector may be preferred for aesthetic reasons to the regular endings of $/ \mathrm{kar}-/$ 'do' in the perfective. Although its original lexical meaning is 'drop' (intransitive), it might be glossed as 'do completely', a nuance that seems more fitting in some contexts than others:

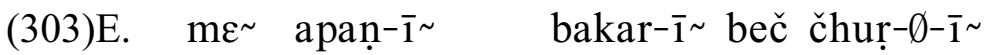

1sg.AG REFL-NOM.M.SG goat-F.PL sell drop-PERF-F.PL

'I sold my goats.'

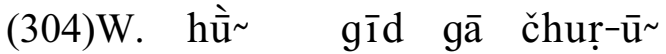

1sg.NOM song sing drop-1sg

'Should I sing a song?'

/le-/ 'take' occurs with transitive verbs, conveying a nuance of completion:

(305)E. me roṭ- $\overline{1}$ khā la- $\emptyset-\overline{1}$

1sg.AG bread-F.SG eat take-PERF-F.SG

'I already ate.'

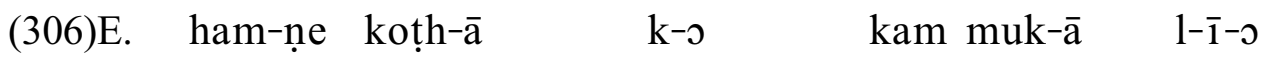

1pl-AG house-OBL.M.SG GEN-NOM.M.SG work finish-CAUS take-PERF-M.SG

'We finished the work on the house.' 
/de-/ 'give' occurs with transitive verbs, conveying a nuance of completion:

$$
\begin{array}{llll}
m \varepsilon^{\sim} & \text { roṭ- } \overline{1} & \text { khā } & d-\emptyset-\overline{1} \\
\text { 1sg.AG } & \text { bread-F.SG } & \text { eat } & \text { give-PERF-F.SG }
\end{array}
$$

'I ate.' (cf. the ungrammatical/*me $\operatorname{roṭ} \overline{1}$ khāi $\overline{1} /$ 'I ate.')

(308)W. dīnā duj̆-o čhoḍ ditt-o

tomorrow second-NOM.M.SG leave give.PERF-M.SG

'The next day [they] left the second one.'

Note that example (307) contains a variant of the perfective form of /de-/ 'give', whereas (308) contains the usual form (i.e. that attesting the Sanskrit/-ita/ suffix).

/sat-/ 'throw' occurs with transitive verbs, especially with 'give':

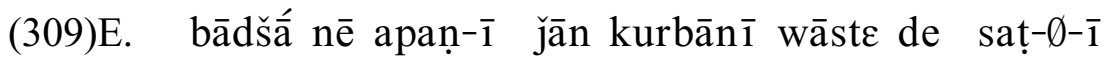
king AG REFL-F.SG life sacrifice for give throw-PERF-F.SG

'The king gave his life as a sacrifice.'

\subsubsection{Modals}

Gojri uses a small number of verbs in modal constructions which modify the sense of the main verb without affecting its lexical content. These modals express notions which cannot occur in isolation, i.e. they require a verbal complement to make any sense (Masica 1991:374). Each requires the main verb to be in a particular morphological shape, with the 'modal' verb receiving whatever inflection the main verb would otherwise take. I discuss them in turn.

/hàk-/ /sak-/ 'be able' > be able to $\mathrm{V}$

/hàk-/ /sak-/ occurs with the bare stem of the main verb, expressing the capacity of the agent to perform the main verb: 


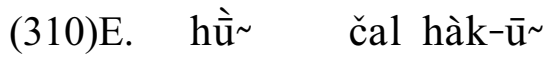

1sg.NOM go able-1sg

'I am able to go.'

(311)W. me kúj ná pár hàk-ī-o

1sg.AG INDEF.NOM.PL NEG read able-PERF-M.SG

'I wasn't able to study at all.'

The two forms of this verb are in free variation in both of these dialects, but my research assistants believe that /sak-/ is preferred in Kashmir.

/čấ-/ 'want' with the infininitive > want to $\mathrm{V}$

/čá-/ occurs with the infinitive of the main verb, expressing the agent's desire to perform the action of the main verb.

$$
\begin{array}{lll}
\text { h } \bar{u}^{\sim} & \text { čal-ṇ-o } & \text { čấ-̄̄ } \\
\text { 1sg.NOM } & \text { go-INF-NOM.M.SG } & \text { want-1sg }
\end{array}
$$

'I want to go.'

$\langle\mathrm{p \varepsilon}-/$ 'fall' with the infinitive $>$ must $\mathrm{V}$

/pe-/ occurs in experiencer constructions (i.e. where the subject is marked by dative case) with the infinitive of the main verb, expressing obligation or constraint to act from a source outside the agent (Masica 1991:380). ${ }^{4}$ The use of /pe-/ 'fall' to express this nuance is similar to the the English, 'It fell to me to present the report.' This verb has irregular forms which differ between the two dialects (see Appendix C):

(313)E. min-nā čal-ṇ-o po-

1sg.OBL-DAT go-INF-NOM.M.SG fall-2/3sg

'I am obligated to go.' 


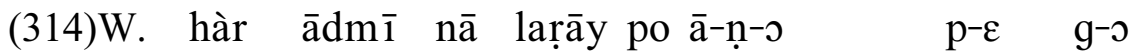
every person DAT fight on come-INF-M.SG fall-2/3 FUT-M.SG

'Every man will be obligated to come to the battle.'

/čáye/ with the infinitive > ought to V (Urdu, not used in female speech)

/čáye/ occurs in experiencer constructions with the infinitive of the main verb, expressing the advisability of acting but without any sense of compulsion:

(315)E. min-nā čal-ṇ-o čấye

1sg.OBL-DAT go-INF-NOM.M.SG is.needed

'I ought to go.'

The infinitive in this and the preceding two constructions represents what Masica has analyzed as the Unspecified (or 'future') Passive Participle (1991:322-324).

/de-/ 'give' with oblique infinitive $>$ allow to $\mathrm{V}$

/de-/ occurs with the oblique infinitive of the main verb, expressing the willingness of the nominative agent to allow another party (the dative indirect object) to act:

(316)E. wó min-nā čal-uṇ $\mathrm{d} \overline{1}-\varepsilon$

3sg.DIST.NOM.M 1sg.OBL-DAT go-INF.OBL give-2/3sg

'He allows me to go.'

\subsubsection{Secondary Aspectuals}

Gojri uses a small number of verbs to further specify the aspect of the main verb. I consider them in turn.

$\underline{\text { Iré-/ 'stay' > finish V-ing / have already V-ed }}$

$/ \mathrm{r} \varepsilon$-/ occurs with the bare stem of the main verb, expressing the completion of a verbal action prior to the present time and situation. Since /r攺/ 'stay' is inherently intransitive, it can never occur with agentive case in an ergative construction (even though its lexical 
meaning is lost in this type of construction). Compare (317) with its ergative counterpart in (318):

(317)E.

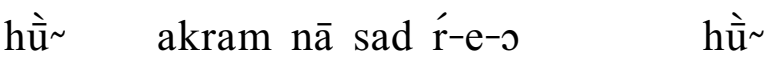

1sg.NOM Akram DAT call stay-PERF-M.SG 1sg.NOM

'I have already called Akram [he hasn't come].'

(318)E. me akram sad-e-o hè

1sg.AG Akram call-PERF-M.SG 2/3sg.PRES

'I have called Akram [he has arrived ].'

$\underline{\text { lag-/ 'attach' with oblique infinitive }>\text { begin to } \mathrm{V}}$

/lag-/ occurs with the oblique infinitive of the main verb, expressing inceptive aspect. Inceptive aspect describes the beginning ('inception') of a verbal action. Examples (319)(321) illustrate the basic use of the inceptive:

(319)E. wá mer-e dar kùl-ụ̣ lag ga- $\varnothing-\overline{1}$

3sg.DIST.NOM.F 1sg.GEN-LOC direction fight-INF.OBL attach go-PERF.F.S

'She started arguing with me.'

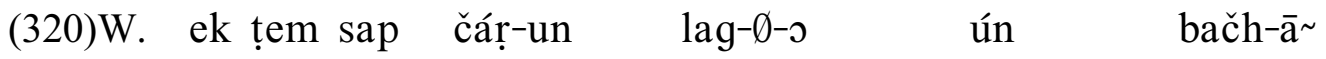
one time snake climb-INF.OBL attach-PERF-M.SG 3pl.DIST.OBL animal.baby-OBL.PL tā khā-ụ̣ nā. direction eat-INF.OBL DAT

'At some [point in] time, a snake started climbing to eat those chicks.'

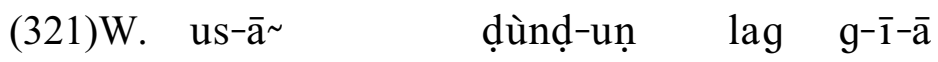

3sg.DIST.OBL-DAT search-INF.OBL attach go-PERF-M.PL

'They started looking for him.'

In narrative, the inceptive with / $\mathrm{k}^{\prime}-/$ 'say' is the preferred formula for introducing reported speech, particularly at the beginning of conversations or where the speech 
consists of single statements. While a literal translation of this formula would be 'started to say', a more accurate rendering would require perfective or habitual aspect per parallels in English discourse:

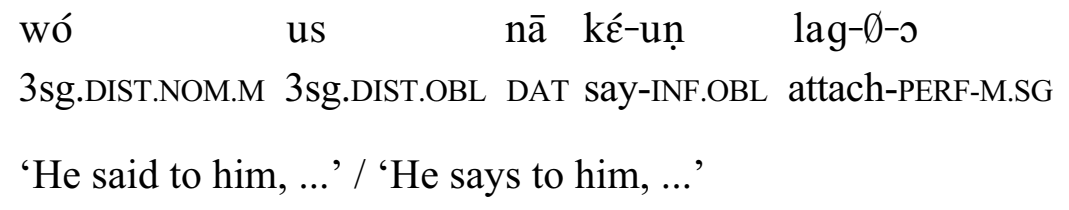

Like its Indo-Aryan relations (Masica 1991:384), Gojri uses the verbs stay, go, and do in combination with a participial form of the main verb to further specify imperfective aspect:

$\underline{\text { ré-l 'stay' > keep on V-ing }}$

/ré-/ occurs in any tense with the imperfective participle, adding a nuance of continuation to the habitual aspect. /ré-/ receives whatever inflection would otherwise be associated with the main verb. In (323) the addition of /ré-/ connotes the subject's effort to sit every morning, whereas the Present Habitual in (324) merely states the subject's habit without implying his or her deliberate continuation in it:

(323)E. subā subā nā hù̀ čat apar bes-t-o rá- $\bar{u} \sim$ morning morning DAT 1sg.NOM roof on sit-IMPFV-M.SG stay-1sg 'I keep sitting on the roof every morning.'

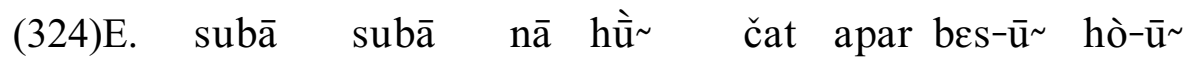
morning morning DAT 1 sg.NOM roof on sit-1sg be-1sg 'I sit on the roof every morning.'

(325)W. tam rāt ke kar-t-ā $\quad$ r $-\overline{1}-\bar{a} \quad \varepsilon$ 2pl.NOM night what do-IMPFV-M.PL stay-PERF-M.PL PRES 'What have you kept on doing all night?' 
Since the Gojri habitual cannot occur with the future tense (cf. 4.2.1.2.5), any future habitual notion must be expressed by the future of /ré-/ with the imperfective form of the main verb (such usage approaches grammaticalization). In such cases the sense of continuance may survive in addition to the broader habitual denotation. Compare examples (326)-(327):

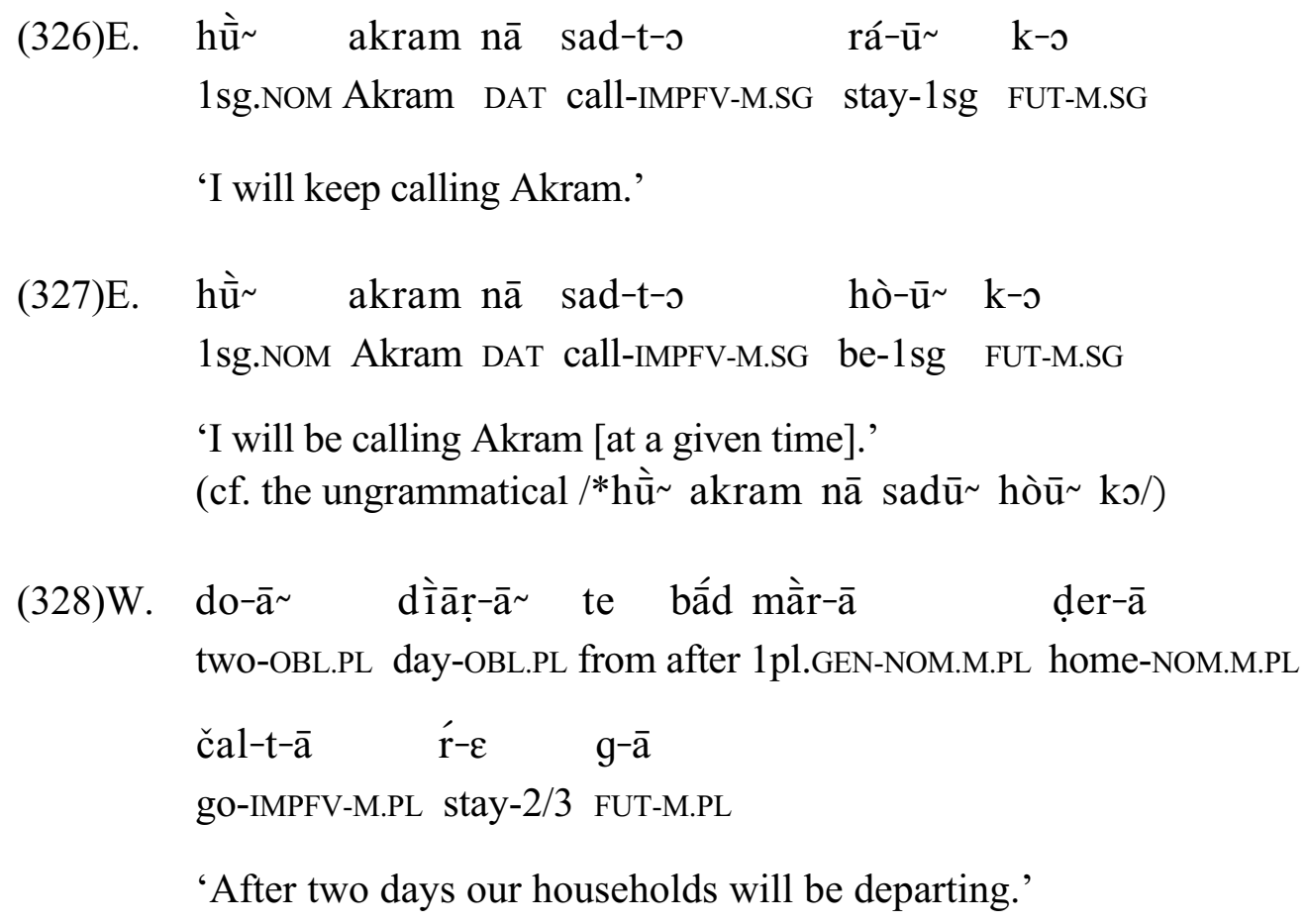

There is one common idiom in my data in which this construction contains the perfective rather than imperfective form of the main verb /tik-/ 'stay':

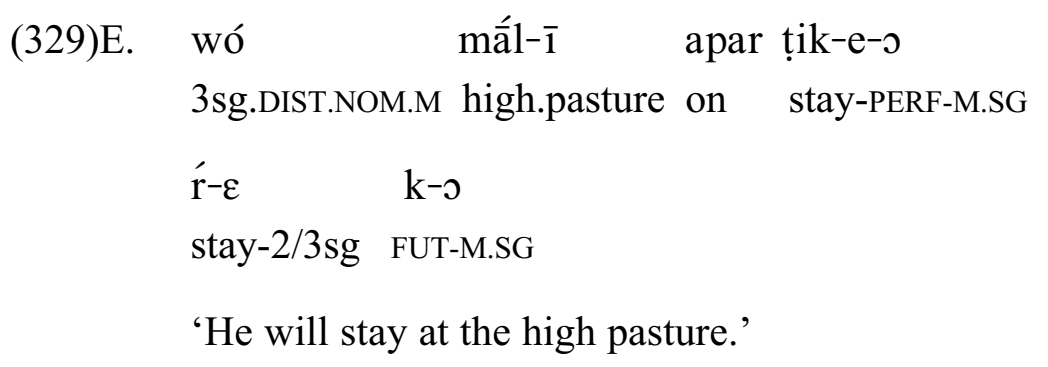


/čal-/ 'go' > go on V-ing

/čal-/ occurs with the imperfective participle in imperatives, expressing a type of 'progressive aspect' that indicates continuation despite some kind of resistance or limitation (Masica 1991:269). It receives whatever inflection would otherwise be associated with the main verb. The verb /čal-/ 'go' is irregular in the perfective, where its stem is $/ \mathrm{g}-/$. My research assistants say that /čal-/ could be replaced with $/ \mathrm{r} \varepsilon$-/ without change in meaning in the following examples:

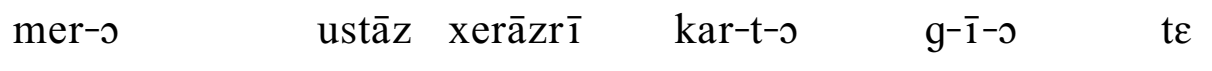
1sg.GEN-NOM.M.SG teacher absenteeism do-IMPFV-M.SG go-PERF-M.SG and hì $\sim \quad$ likh-t-o g-ī-o 1sg.NOM write-IMPFV-M.SG go-PERF-M.SG

'My teacher went on absenting himself and I went on writing.'

(331)E. $\begin{array}{llllll}\text { tārā us } & \text { ḍāl- } \overline{1} & \text { nā le } \quad \text { ke mār-t-o } & \text { g-ī-o, } \\ \text { Tara 3sg.DIST.OBL } & \text { bar-FEM.SG } & \text { DAT } & \text { take CP kill-IMPFV-M.SG } & \text { go-PERF-M.SG }\end{array}$ mār-t-o $\quad g-\overline{1}-\overline{-}, \quad$ mār-t-o $\quad g-\overline{1}-\jmath$ kill-IMPFV-M.SG go-PERF-M.SG kill-IMPFV-M.SG go-PERF-M.SG

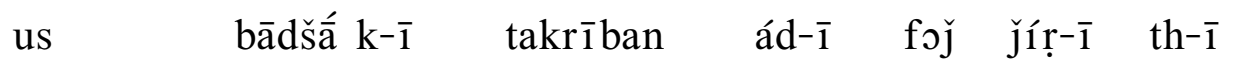
3sg.DIST.OBL king GEN-F.SG approximately half-F.SG army REL-F.SG PAST-F.SG

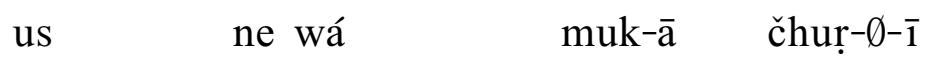
3sg.DIST.OBL AG 3sg.DIST.NOM.F finish-CAUS drop-PERF-F.SG

'Tara, taking the branch, kept on killing and killing and killing. He finished off almost half of the army that the king had.'

$\underline{\text { kar-l 'do' }>\text { make a habit of V-ing }}$

/kar-/ occurs only in compound imperatives, with the main verb stem taking the 'older' invariant perfective suffix /-eā/ $(/-\overline{1} \bar{a} /)$. It expresses future habitual action. There 
are no marked future imperative forms of this construction, as the notion of future time is inherent. Note the compounded variant in (332)b.:

(332)E.a. pāṇ $\overline{1} p \overline{1}-\bar{a} \quad k a r-0$ water drink-PERF do- $2 p$

'Always drink water!'

b. pāṇ $\overline{1}$ pī-ā kar-eā kar-o

water drink-PERF do-PERF do- $2 \mathrm{p}$

'Always drink water!'

(333)W. dwā kar-1̄̄ā kar

prayer do-PERF do

'Always pray!'

\subsubsection{Adverbs}

Gojri adverbs are those words which convey adverbial notions all by themselves, notions that might otherwise be conveyed by a multi-word phrase. Gojri adverbs therefore specify some property of the verbal event or situation, or of an adjective or other adverb. Adverbs occur outside of noun phrases almost anywhere prior to the verb, and a few adverbs like /wīil / /bì /, /be/) 'also' may be allowed between the verb and a following auxiliary.

Morphologically related sets of adverbs are shown in Table 27 below. I then list other examples of the several classes of Gojri adverbs in 4.2.3.1-5. The few Gojri adverbs which inflect for agreement with the subject are shown in 4.2.3.1-5 as stems, with the hyphen indicating that an $\mathrm{AC}$ marker is required. 
Table 27. Interrogative/Relative/Proximate/Distal Adverb Sets

\begin{tabular}{|c|c|c|c|c|}
\hline Adverb Type & Interrogative & REL & PROX & DIST \\
\hline of place: 'Where?' & kit & jit & it & ut \\
\hline of place (w/locative): & $(\text { kit } \varepsilon)^{*}$ & jite & it $\varepsilon$ & ute \\
\hline of origin (w/ablative): 'Whence?' & kitū & jitū & itū & utū \\
\hline of direction: 'Whither?' E & $\mathrm{k} \overline{1} \sim \overline{\mathrm{a}}$ & $\bar{j}^{\overline{1}} \sim \overline{\mathrm{a}}$ & $\overline{1} \sim \bar{a}$ & $\mathrm{u}^{\sim} \overline{\mathrm{a}}$ \\
\hline $\mathrm{W}$ & kingā & juingā & ingā & ungā \\
\hline of degree: 'To what degree?' & kitno & jitno & itno & utno \\
\hline of time: 'When?' & $\mathrm{kad}$ & jad & is - & us - \\
\hline of time: 'When?' & kičar & jičar & ičar & učar \\
\hline of cause: 'Why?' & $\mathrm{ky} \overline{\mathrm{u}} \sim$ & --------- & -------- & -------- \\
\hline of manner: 'In what manner?' E & kis tareā $\sim$ & jis tareā $\tilde{}$ & is tare $\bar{a} \sim$ & us tareā \\
\hline $\mathrm{W}$ & kis $\operatorname{tar} \overline{1} \bar{a} \sim$ & jis $\operatorname{tar} \overline{1} \bar{a} \sim$ & is $\operatorname{tar} \overline{1} \bar{a} \sim$ & us $\operatorname{tar} \overline{1} \bar{a} \sim$ \\
\hline of manner: 'In what manner?' & kišāne & jišs̄āne & išāne & ušāne \\
\hline " (w/ablative) & kenū & ǰnnū & $\varepsilon n \bar{u}$ & ----------- \\
\hline
\end{tabular}

The form */kite/ is not an interrogative. Rather it is an indefinite adverb meaning 'somewhere, somewhat, sometimes.' The interrogative adverb /ky $\bar{u} \sim /$ 'Why?' is answered by $/ \mathrm{ky} \overline{\mathrm{u}} \sim \mathrm{ke} /$ or $/ \mathrm{ky} \overline{\mathrm{u}} \sim$ je/ 'because.'

\subsubsection{Other Adverbs of Manner}

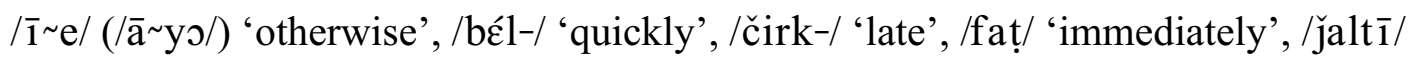
‘quickly', /jàb/ 'quickly' (W. only), /hòle/ 'slowly', /ǰ̄1/ 'at that moment', /lug-/ 'freely', /mat/ 'never' (in prohibitions), /nakūk/ 'deeply' (of sleep), /nasāpe / 'suddenly', /nú̄̄/

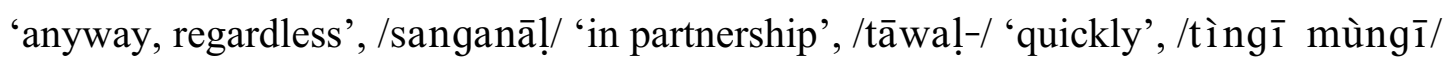

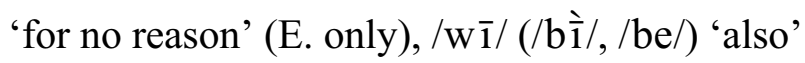




\subsubsection{Other Adverbs of Time}

/ajāa $\sim /$ 'at the moment, right now' (occurs in negative constructions), /age re / 'several

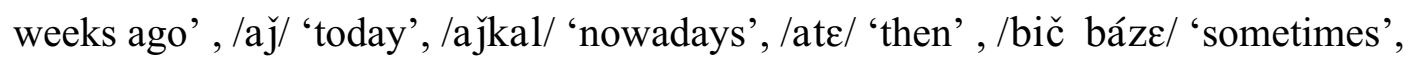

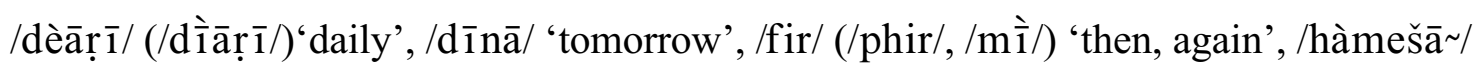
'always', /hòṇ/ 'now', /itnā bičū/ 'meanwhile', /kade kade/ 'occasionally', /kấḍū/ 'afterwards', /munḍū/ 'from the beginning', /par/ 'last year', /parār/ 'two years ago', /sabel/ 'early in the morning', /tade/ 'a little earlier, a short time ago', /terā $\sim$ ' this year', /waxt $\overline{1}$ / 'early in the morning' (W.only)

\subsubsection{Other Adverbs of Place and Direction}

Many adverbs of this class feature a directional suffix $/-\overline{\mathrm{a}} \sim /$ which resembles the dative case-marking postposition /nā/ in many ways. Others feature the ablative suffix /-ū/. Examples of this class include:

/afrā / 'upwards', /agā / 'up ahead', /andrū// 'from out of', /aprūu 'from off of, from out of' (E. only), /āmṇe sāmṇe/ 'opposite one another', /bấr/ 'outside, abroad',/bičū/

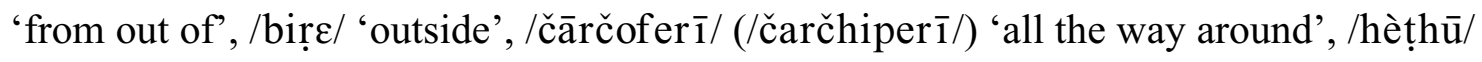
'from under', /kấḍ/ 'behind', /koḹ̄/ 'from near', /parā / 'in that direction', /parū/ 'from across', /parlūte/ 'across and down', /parūte/ 'next door', /pičhā $\sim /$ 'in the mountains, toward the mountains', /tale/ 'down', /taṇā/ 'in the plains, toward the plains', /taū te/ 'from below', /tấ / 'toward the low lands', /té/ 'down', /upar/ 'above', /urāa / 'in this direction', /urā̃ parā / 'every which way', /urūte/ 'from adjacent location.' 


\subsubsection{Other Adverbs of Degree}

/baṛ-/ 'very', /bilkul/ 'completely, totally', /kúj/ 'somewhat', /muč/ 'very', /sirf/ 'only' (Urdu, rare in female speech), /sirū/ 'completely, totally', /takrīiban/ 'approximately' (Urdu, rare in female speech), /thor-/ 'a little', /zarī/ 'slightly, a little'

\subsubsection{Epistemic Adverbs}

Adverbs of this class 'indicate the degree to which the speaker is committed to the truth of the clause' (Payne 1997:70). The most common such Gojri adverb has grammaticalized from the perfective of the verb /pe-/ 'fall' and denotes the speaker's positive disposition toward the verbal clause, rather than his or her commitment to its truth, per se. This adverb agrees with the subject in gender and number, although there is no marked femine plural form. Translations include 'surely', 'certainly', and 'go ahead'. Consider examples (334)-(335):

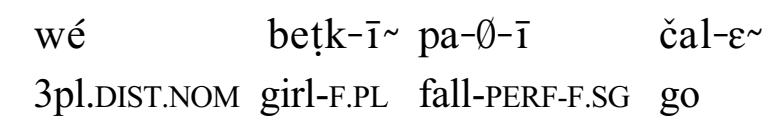

'Sure those girls can go.'

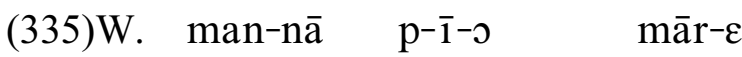

1sg.OBL-DAT fall-PERF-M.SG hit-2/3

'Let him attack me.' / 'I don't care if he attacks me.'

Other examples of this small class of adverbs include /bilkul/ 'absolutely', /lāzm̄̄ / 'surely', /xās kar/ 'especially', and /zarūr/ 'certainly'. 


\section{CHAPTER V}

\section{TOWARD STANDARDIZED GOJRI SPELLINGS AND LITERATURE}

\subsection{Dialectal Variation and the Standardization of Gojri}

The intelligibility testing conducted by Hallberg and O'Leary demonstrated empirically that Gujars are justified in believing that Gojri is a single language with regional variance (1992:126). In my opinion, the phonological and morphological variation noted above between Eastern and Western forms of Gojri speech is relatively limited and should not therefore constitute a major obstacle to the emergence of a unified literary standard. The nature of the dialectal differences may provide a partial explanation for Hallberg and O'Leary's tentative observation that Western speakers are better able to understand the speech of Eastern Gujars than the other way around (1992:127). They had speculated that Eastern Gojri might be an older form of the language that facilitated a latent receptive competence among Western speakers, or that the greater similarity of Eastern Gojri to Urdu and Punjabi (observed via word list comparisons and attitude surveys) might make Western Gujars who are exposed to those languages more likely to understand Eastern Gojri.

While I believe that the ability of Western speakers to understand Eastern speech lies primarily in their greater exposure to Eastern Gojri (and Urdu), the comparative morphological data do suggest that Eastern Gojri retains older forms. Various inflectional distinctions made in Eastern are collapsed in Western, and those distinctions also correspond - formally in some cases - to those made in Urdu and Punjabi. Related to this 
is the fact that many Eastern-speaking Gujars with whom I have contact regard the Western dialect, if they are even exposed to it, as having a corrupted or otherwise incorrect grammar (citing missing inflections), and therefore unworthy of attention. On the other hand, Western Gujars take a high view of the Eastern Gojri they enjoy on the radio, regarding it only as slightly 'different' from their own speech. They seem to take it as a given that any literature development, like radio programming, will emanate from Kashmir, where Gujars and Gojri are more influential than in Pakistan's North-West Frontier Province.

Despite this apparent willingness of Western-speaking Gujars to follow the lead of Eastern speakers in language development, I believe that they should be encouraged to produce a limited literature and develop primary literacy programming in their own dialect. Early on in the pilot literacy project which I conducted together with my research assistants, it became clear that, beyond a common alphabet book, they and other literate Gujar stake-holders wanted separate Eastern and Western reading primers. Their enthusiasm for 'mother-tongue literacy' is tied to the materials being written in their own mother tongue (i.e. not in someone else's mother tongue). A small example of such attitudes involves the future auxiliary $/ \mathrm{k}-/(/ \mathrm{g}-/)$, for which some Eastern speakers resist an Urdu-based /g-/ spelling, complaining, 'we don't say that!'

The morphological and lexical differences, limited as they are, still affect almost every line of written text, such that new readers working with materials from the other dialect end up memorizing some lesson content by rote rather than merely decoding what is familiar (I have experimented in both directions). Pushing Eastern Gojri primers or hybrid Gojri primers onto the Western dialect community might discourage broad-based 
involvement in non-formal literacy programs. Development of Western Gojri at this minimal level might also raise the profile of the dialect sufficiently for it to be taken more seriously by Eastern developers, who in any case should see the Western community including Allaiwal Bakarwals living in Indian-administered Kashmir - as a way to emphasize the geographic breadth and numeric strength of the Gojri language in their campaign for wider recognition and support (not to mention maximizing their own audience).

After gaining initial skills in their own dialect, Western students can proceed with the Urdu curriculum in either a government school or non-formal literacy program. Through Urdu, then, Western students will learn the spellings for such Eastern forms as the present auxiliary $/ \mathrm{he} \sim /$, the feminine plural AC marker $/ \overline{\overline{1}} \sim /$, and the second and third person plural PC markers, /-o/ and /- $\varepsilon^{\sim} /\left(\operatorname{Urdu} /-\mathrm{e}^{\sim} /\right)$, respectively. Such a program would leave very little in Eastern-dialect publications to appear foreign to the Western reader, because the 'gain' of inflectional information and spellings would have been largely achieved via Urdu. For female students, the non-formal curriculum could be structured for direct progression to Eastern Gojri materials, since female Gujars are less likely to learn spoken Urdu outside of a formal setting. Materials could also be developed in Eastern Gojri to teach Urdu as a foreign language to monolingual speakers from both dialects.

\subsection{Approaches to Spelling: Theoretical Considerations}

The traditional taxonomy of orthography types distinguishes two broad spelling approaches for alphabetic writing systems: the phonemic or 'shallow' representation which generally corresponds to pronunciation, and the morphophonemic or 'deep' 
representation of underlying forms. The product of the former should also be distinguished from phonetic spellings which represent predictable allophonic detail. There are advantages and disadvantages to each approach.

\subsubsection{From Phonology}

Since its advent in the early to mid-80's, the theory of Lexical Phonology has provided a strong endorsement for a 'shallow' or phonemic orthographic representation. Mohanan argues that an orthography should represent the 'lexical alphabet', which approximates the phonemic inventory of a language (1986:194,176-177). In his discussion of the psycholinguistic perceptions of a language's speakers, Mohanan provides the basis for understanding why phonemic spellings are generally superior to phonetic or morphophonemic spellings:

Speakers of a language can be trained in a matter of hours to interpret 'phonemic' transcriptions (those using the lexical alphabet), and then learn the pronunciations of unfamiliar words from a pronouncing dictionary. All that one needs for this purpose is the key for the symbols, with a few examples. Equally simple is training in producing lexical phonemic transcriptions: my informal experiments show that speakers of the same dialect come up with the same phonemic transcriptions for a given set of spoken nonce forms.

In contrast to the ease with which one can train naive speakers to read and write lexical phonemic transcriptions, it is nearly impossible to train an average speaker to read and write phonetic transcriptions: this would require a great deal of training in articulatory phonetics ... Equally laborious is training in reading and writing underlying representations, which would require special training in the phonological analysis of the language involved. What I am saying, in other words, is that all speakers of a language have direct conscious access to representations in terms of the lexical alphabet by virtue of knowing the language. Only a few have conscious access to underlying representations and phonetic representations, since conscious access to these two levels is provided through specialized training in phonetics and phonology. (1986:194)

He goes on to summarize the implications for spelling and literacy: 
It is not an accident that many languages have based their orthographic systems on the lexical alphabet. The orthographic system of Malayalam ... is a syllabary that is phonemic. As a result, it has the property that speakers do not have to learn the pronunciations of unfamiliar words by listening to the spoken form or consulting a pronouncing dictionary: the orthographic representation of a word conveys everything that a speaker needs to know in order to pronounce the word. Thus, literacy in Malayalam is achieved by merely learning the regular correspondences between letters and sounds.

This structural property has a behavioural correlate: given unfamiliar words in the written form, literate speakers pronounce them 'correctly' (i.e. the way they are pronounced by others), and given unfamiliar words in the spoken form, they assign 'correct' written representations to what they hear.

In contrast, literate speakers of English need to check the correspondence between spelling and pronunciation for every new word that they come across. Clearly, this is related to the fact that the orthographic system is not lexical phonemic in English ...' (1986:195)

By advocating a 'shallow' orthography, Lexical Phonology provides unqualified support for the approach to tone representation explored for Gojri in 3.2, because it sees tone spreading like that in Gojri as a post-lexical process (Pulleyblank 1986). Stated another way, the results of tone spread in Gojri are phonetic or allophonic in nature, rather than contrastive/phonemic, and do not need to be written (Bird 1996:32). Bird's (1997) documentation illustrates for surface tones what Mohanan avers about surface detail in general: training a native speaker to accurately read and transcribe it is virtually impossible.

\subsubsection{From Reading Theory}

The findings of recent reading studies support the implications of Lexical Phonology for orthography design, while providing additional insight about how readers process text. Adams finds that, prior to the development of a large sight vocabulary, 'the connections between orthography and phonology are extremely important for the young reader; as for the skillful reader, however, the importance of phonological processing is as a means or 
support system' (1990:215). Contradicting the long-held notion of many linguists and educators that 'deep' etymological spellings enable readers to bypass phonological processing in word recognition, she cites research by Ehri and Wilce (1986) indicating that 'the morphemic structure of a word does not influence learners' image of its phonological structure or, by extension, its spelling. Instead their results invite the converse explanation: that morphemic appreciation derives from our knowledge of words' spellings and our image of their phonological structures' (1990:400).

A related finding with major implications for orthography design is that readers recognize words by automatically parsing words into syllables, not into morphemes (Adams 1990:121-124). This parsing is dependent upon the reader's knowledge of spelling patterns, which consists of associative connections between letters that are learned via phonological processing. One consequence for the cursive Arabic script, I believe, is that such parsing may be complicated by the existence of several allographs for the same pronounced syllable. Where there are no other constraints, the avoidance of longer, joined spellings might simplify the syllabification component of word recognition.

Adam's conclusions about the reading process do not contradict what cross-cultural literacy practitioners have advocated about orthography design; her entire discussion assumes standardized English spellings. Two general principles continue to guide the development of spelling conventions where they have not been standardized: consistent representation of morphological affixes (Walter 1995), and maintenance of 'fixed wordimages' based on the isolation form of the word (Voorhoeve 1964:130-131, cited with reference to tone orthographies in Bird 1996:12-23). It is possible that syllabification is also complicated by allophonic-level spellings, which multiply the number of visual images associated with morphemes subject to minor surface variations. To my 
knowledge, however, the case for maintaining the visual consistency of words and grammatical morphemes has not been established through comparable research.

\subsubsection{Simons' Principles of Multidialectal Orthography Design}

Simons (1994) outlines seven principles for designing an orthography that enables readers of phonologically divergent dialects to read their own pronunciations from a single representation while maximizing the political and economic benefits of 'joining'. A multidialectal orthography represents 'levels of phonological structure at which skewed phonemic systems converge. By lifting an insistence on 'phonemic' orthographies, we may be able to discover a solution at a phonetic, morphophonemic, or fast speech level which finds agreement between all dialects, whereas the phonemic solution would find disagreement' (1994:16). Such an orthography stands in contrast to a unidialectal orthography which corresponds only to the phonology of the most socially acceptable dialect of a language (Gudschinsky 1973). The English orthography is a prime example; its morphophonemic, deep etymological spellings unite in one representation a host of spoken varieties, some of them mutually unintelligible.

Simons proposes that, in evaluating alternative solutions in the design of a multidialectal orthography, that solution is to be preferred which (1) is the most socially acceptable; (2) is the most psycholinguistically acceptable (psychologically 'real' to speakers); (3) minimizes potential ambiguity; (4) minimizes the number of symbolized contrasts; (5) finds a level of phonological structure at which skewed systems converge; (6) symbolizes (in the unified orthography) a given phonemic contrast in one dialect when ease of reading warrants top consideration, or symbolizes another dialect's neutralization of that contrast when ease of writing warrants top consideration; and (7) entails the overall least effort for illiterates to become fluent readers: 
The greater the overall effort required to master an orthography, the greater is the overall cost of conducting a literacy program. This cost is realized in at least two ways: the cost of losing students and thus failing to produce readers, and the actual expense in terms of time, teachers, and equipment required for conducting the program. The cost in terms of losing students is the more serious. Ability to succeed in becoming a fluent reader is largely governed by motivation. In a very real way, the effort required to learn can affect one's motivation. Difficulties and long periods without any seeming progress can lead to frustration and discouragement. These in turn may lead to loss of motivation and giving up. The less time and effort required to gain mastery, the greater the chances that the individual student will succeed. (Simons 1994:27)

As the phonemic inventories of Eastern and Western Gojri are virtually identical, Gojri is clearly not a classic case of the situation Simons addresses. Still, these principles might be extended to the representation of morphological differences and sub-phonemic variation. For example, I am convinced that the 'iconic', etymological solution considered in 3.2.2.4 for the representation of low tones resulting from the de-aspiration of initial voiced aspirates is preferable to other solutions in terms of all seven criteria.

Furthermore, this and other Urdu-based solutions make sense if the principles, particularly the seventh, are applied beyond the dialect differences to the broader language environment in which Urdu predominates - that is, if Gojri and Urdu are seen as sister dialects. In that light, the 'cost' of producing Urdu-literate Gujars via confidence and skill-building primary literacy in their mother-tongue is minimized to the extent that the Gojri orthography resembles Urdu. Departures from Urdu conventions add to the student's total learning task, without adding to the resources available. While the governments and economies of English-speaking countries are able to support a literacy task that is protracted due to its orthography, South Asian governments and Gujars themselves have no such luxury. 


\subsection{Gojri Spellings}

What follows is only a partial listing of spelling-related issues not already addressed in 2.6 and 3.2.2. I have not, for instance, taken time to treat each of the post-lexical processes reported in 2.5 in light of a phonemic spelling approach. The discussion below does, however, provide considerable documentation as to the scope of orthographic variation in Gojri. My purpose is to report and evaluate spelling patterns which have a bearing on the spelling of many words, and on that basis advance the discussion of the spelling of select high-frequency grammatical words. The uniquely Western spellings presented below are in use, to my knowledge, only by myself and those Western speakers who are associated with the literacy project and are not therefore indicative of any truly indigenous activity in that dialect.

\subsubsection{Basing a Word's Spelling on its Isolation Form}

This principle can be illustrated via application to the Gojri verb 'give', which is often written with high tone as ديبه per the pronunciation of the 'bare' singular imperative form, /dé/, and a perceived contrast with the Urdu imperative form as well as with the Gojri /de/ 'giant'. Writers are confused, though, when writing suffixed forms of 'give', since inflected forms alternate between low and level tone (see the paradigm for 'give' in Appendix C). The imperative, however, is not the isolation form of the Gojri verb, as it receives additional stress. The isolation form of the verb is, rather, that which occurs in the conjunctive participle construction (4.2.1.7), as is shown in (336):

$$
\begin{aligned}
& \text { de de } k \varepsilon \quad g-\overline{1}-\supset \\
& \text { giant give CP go-PERF-NOM.M.SG } \\
& \text { 'The giant gave [it to them] and went.' }
\end{aligned}
$$


Here there is no tone contrast between 'give' and 'giant'; they are homophones. The approach advocated by Bird (1996), then, would spell the stem /de-/ 'give' as 2 in all of its forms.

\subsubsection{Consistent Representation of Morphological Affixes}

An application of the consistent representation of morphological affixes involves a post- lexical process for the infinitive suffix /-n/, which is replaced with /-n/ following any retroflex sonorant (see 2.5.4). A phonetic spelling of /āṇṇı/ [a:ṇənə] 'to bring', therefore, is آنّو, reflecting this replacement. A decision to represent suffixes consistently, however, would write the infinitive suffix as retroflex in all environments, e.g. نِنّو 'to bring'.

\subsubsection{Words Involving Perseveratory Nasalization}

Since nasalization of vowels is predictable following a nasal consonant (cf. 2.5.6), there is no need to write nasality thereby produced. This convention seems to be selectively applied in Urdu, e.g. nasality is written for /me/ 'in' but not for the ergative postposition /ne/. For example, the Gojri dative postposition /nā/ [na: ] and the postposition /mā/ [ma: ] 'in' could be written without nun gunno, $\mathcal{U}$, as and o ا نا ,

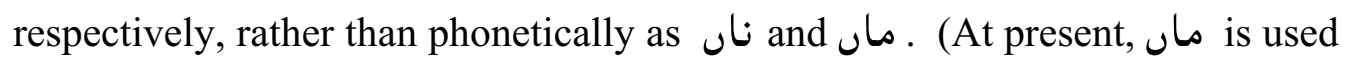
universally, and the two spellings of /nā/ are in free variation in Indian-administered Kashmir while only نان occurs in publications on the Pakistan side.)

Words like /nā / [na: ] 'name' and /mā $\sim /$ [ma: ]'mother', which feature underlying nasality stemming from the erosion of a historic nasal consonant, should continue to be 
written with nun gunno after the vowel: as نان and respectively. The underlying nasality of suffixes such as the oblique plural $/-\overline{\mathbf{a}} \sim /$ and the feminine plural $/-\overline{\mathbf{1}} \sim /$ (Eastern only) should not be mistaken for cases of perseveratory nasalization when following a nasal consonant - and thus written without nun gunno. Rather, they should be written with nun gunno regardless of the environment.

\subsubsection{Stems Ending in Nasalized Vowels}

As another application of a commitment to consistently represent morphological affixes, stems ending in nasalized vowels would be written with nun gunno prior to any suffix, even if the nasality extends through a suffixed vowel in the speech of some. Two examples involving the nominative masculine singular AC suffix /- $\mathrm{\jmath} /$ are shown in (337). (337) Spellings of stems ending in a nasalized vowel (note medial form of nun gunno)

\begin{tabular}{|c|c|c|}
\hline & consistent-suffix spelling & phonetic spelling \\
\hline tù̀ $\sim \rho /(/ d \overline{\bar{u}} \sim \rho /)$ ‘smoke' & دهُونُؤُ & 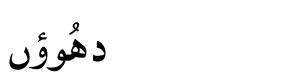 \\
\hline 'scorpion' & لُهُونُؤُ & لطهُؤُ \\
\hline
\end{tabular}

\subsubsection{Constraints on the Employment of Vowel Diacritics}

In Gojri writing, as in Urdu, the use of vowel diacritics is normally limited to the differentiation of otherwise ambiguous spellings. There is simply no need, for example, to specify that the pronunciation of the second and third person singular PC suffix is $/-\varepsilon /$ rather than /-e/ by means of the superscript diacritic, zabbar. On the other hand, it may be desirable to write zabbar to distinguish such grammatical words as $ک / \mathrm{ke} /$ 'what?' and $َ / \mathrm{ke} /$, the genitive-locative postposition, particularly in primary literacy materials. 
The nominative masculine singular AC suffix /- $\mathrm{J}$ / is universally written without a superscript zabbar, thus neutralizing the contrast between $/ \mathrm{o} /$ and $/ \mathrm{o} /$. This practice simplifies reading and writing without introducing any ambiguities.

The neutralization of dialectal variation may be achieved through the omission of vowel diacritics in some contexts. For example, while the difference between the Eastern perfective suffix /-e/ and its Western counterpart / $-\overline{1} /$ could be represented by writing a subscript diacritic zer for Western forms, omitting the zer simplifies both standardization and literacy.

\subsubsection{Constraints on the Adoption of Urdu Spellings}

The notion of an 'Urdu-based' approach to writing Gojri does not mean that every Gojri word should be spelled according to the spelling of its Urdu cognate. In the practice of conscientious, development-minded Gujar writers, Urdu spellings are generally adopted only for stems whose pronunciations approximate those of their Urdu counterparts. Differences in pronunciation consisting of one or more phonetic features are intentionally represented in unique Gojri spellings. Some common examples are shown in (338).

(338) Unique Gojri spellings for words with transparent Urdu cognates

\begin{tabular}{|c|c|c|c|c|}
\hline $\begin{array}{l}\text { Urdu } \\
\text { pronunciation }\end{array}$ & $\begin{array}{l}\text { Urdu } \\
\text { spelling }\end{array}$ & $\begin{array}{l}\text { Gojri } \\
\text { pronunc }\end{array}$ & $\begin{array}{l}\text { Gojri } \\
\text { spelling }\end{array}$ & \\
\hline /kām/ & كام & /kam/ & كَمَ & 'work' \\
\hline /ačhā/ & آجها & /hàčho/ & بَتِهو & masc. sg. \\
\hline$/ \overline{\mathrm{a}} \mathrm{j} /$ & آج & /ăj/ & اَج & 'today' \\
\hline /kučh/ & كُجهر & /kúǰj/ & كُجه & 'some' \\
\hline
\end{tabular}




\begin{tabular}{|c|c|c|c|c|}
\hline /kālīi & كالى & /kāḹi / & كالْى & 'black' fem. \\
\hline$/ \mathrm{or} /$ & اَور & /hòr/ & بَوَر & 'more' \\
\hline$/$ sun/ & سُن & /sun/ & سُنْ & 'listen!' \\
\hline
\end{tabular}

There are exceptions to this general rule. The spellings of a few indigenous tonal words are taken from Urdu, even though they do not map precisely to Gojri pronunciations. One common example is the negative particle $/ \mathrm{n} \frac{1}{1} /$, for which the Urdu spelling نهrdu /nahī /) is utilized in Indian-administered Kashmir. The variant spelling advocated by Sabir Afaqi and utilized in Pakistan and Pakistan-administered Kashmir is نيـrich which precisely maps to the Gojri pronunciation (i.e. it indicates one rather than two syllables, marks high tone with choti he placed after the vowel, and does not mark the underlying final nasality of the Urdu form). Similarly, the Gojri negative particles /ná/ and /na/ [n $\Lambda$ ?] are both written with the Urdu spelling, $\sim$, which would indicate the pronunciation /ná/ if decoded alphabetically. The complementizer/ke/

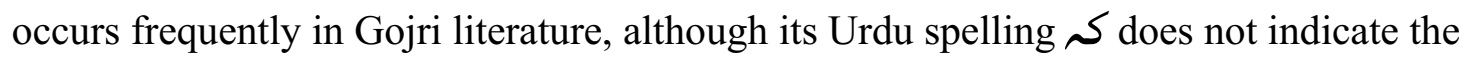
level-tone, long-vowel pronunciation. I am uncertain whether the word itself is indigenous, however, as the allomorph / je/ is more common in spoken Gojri.

While the exceptions noted above stand outside of a strict sound-symbol correspondence, they support the maintenance of fixed word images between Gojri and Urdu and thus simplify the transitional literacy task. If the Urdu spellings of these and other such words remain standard, they should be taught as sight words in Gojri primary literacy materials. 


\subsubsection{Pronouns and Demonstratives}

The standardization of pronominal and demonstrative spellings, like the standardization of tone representation, constitutes an important first step toward the establishment of a Gojri written standard. For these words, dialectal differences are surprisingly minimal, and the obstacles to standardization seem to lie exclusively between members of the Eastern-speaking community.

The spellings of Gojri pronouns and demonstratives are influenced, to varying degrees, by the spellings of Urdu pronouns. The Urdu spellings referenced below are given in Schmidt (1999:15-24).

\section{$\underline{\text { Nominative Forms }}$}

The spellings for first and second person nominative pronouns are shown in Table 28. Table 28. Spellings for First and Second Person Nominative Pronouns

$$
\text { spelling pronunciation }
$$

\begin{tabular}{|c|c|c|c|}
\hline $1 \mathrm{sg}$. & 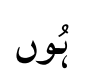 & $/ \mathrm{h} \overline{\bar{u}} \sim /$ & 'I' \\
\hline $1 \mathrm{pl}$. & كَمْ & /hàm/ & 'we' \\
\hline 2 sg. & 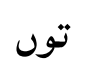 & $/$ to $/(/$ to $/)$ & 'you’ (cf. Urdu /tū/ 'you’) \\
\hline 2 pl. & تَمَ & $/ \operatorname{tam} /$ & 'you' (cf. Urdu /tum/ 'you') \\
\hline
\end{tabular}

The spellings shown in Table 28 are used invariably. The first person spellings have been appropriated directly from Urdu (the singular is taken from the Urdu present auxiliary for first person singular), while the second person spellings have been slightly adapted to reflect slight differences in pronunciation from their Urdu equivalents. 
In primary literacy materials for the Western dialect, the spelling تو might be utilized for the second singular, as it is identical to the Urdu.

The spellings for third person nominative demonstrative pronouns are shown in Table 29.

Table 29. Spellings for Third Person Nominative Demonstrative Pronouns

$$
\text { dominant variant pronunciation }
$$

\begin{tabular}{|c|c|c|c|c|}
\hline masc. sg. prox. & يوه & يو & /yó/ & 'he, this' \\
\hline fem. sg. prox. & ياه & يَم & /yá/ & 'she, this' \\
\hline masc. sg. dist. & وُه & & /wó/ & 'he, that' \\
\hline fem. sg. dist. & واه & وَه & /wá/ & 'she, that' \\
\hline sg. dist. variant & اوه او او & & /ó/ & 'he, she, that' \\
\hline pl. prox. & ي & & /yé/ & 'they, these' \\
\hline pl. dist. & ويـ & Q & /wé/ & 'they, those' \\
\hline
\end{tabular}

Whereas Gojri distinguishes six third person nominative forms, Urdu distinguishes only two (distal and proximate). This partially explains why the Gojri spellings are standard for only three forms: the singular distal variant /ó/, the singular distal masculine /wó/ (appropriated from the Urdu distal), and the plural proximate /yé/ (appropriated from the Urdu proximate). A secondary explanation is geopolitical: the Kashmir conflict has precluded productive discourse and collaboration between Gojri developers on opposite 
sides of Kashmir. Thus, the dominant forms shown for the four remaining pronominal distinctions in Table 29 are in use in Indian-administered Kashmir, while the variants mainly occur in literature produced on the Pakistan side (except for the plural distal variant, which is a secondary form in both areas).

In my opinion, the dominant forms in Table 29 are all excellent candidates for standardization. As a set they have a rough visual symmetry corresponding to the symmetry of their pronunciations, that is, the spellings differ somewhat predictably from one another with respect to the representation of their initial, spatial-marking consonants and their gender and number-marking high-tone vowels. The feminine variants are not visually distinct enough: the singular proximate feminine is too similar to the plural proximate, and the singular distal feminine is too similar to its masculine counterpart, especially given the frequency with which diacritics are omitted. Likewise, the singular proximate masculine variant is identical to the digraph often representing the final syllable of the perfective masculine singular (cf. آيو , 'he came') and the plural distal variant is identical to the common sequence /we/ which occurs in many verbal forms (cf. the Eastern آو , 'he comes').

$\underline{\text { First and Second Singular Agentive Forms }}$

The first and second singular agentive pronominal spellings are shown in Table 30. Table 30. Spellings for First and Second Person Singular Agentive Pronouns

$$
\text { spelling pronunciation }
$$

$1 \mathrm{sg}$.

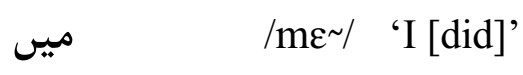

$2 \mathrm{sg}$.

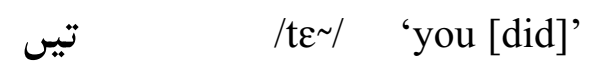


The spellings in Table 30 are used invariably. The first person singular is appropriated from the homophonic Urdu first singular nominative, and the second person singular is spelled on the same pattern.

The nasality of the first person singular form appears to be underlying. That the nasality of both forms is likely a reduction of the agentive postposition /ne/ is suggested by the non-occurrence of /ne/ with these forms and by the free variation observed for the Western third singular forms /is ne/ and /us ne/ and their contracted allomorphs, /ise / and /use $/$, respectively.

First and Second Person Plural Agentive and Dative Forms

The spellings for first and second person plural agentive and dative forms are shown in Table 31.

Table 31. Spellings for First and Second Person Plural Agentive and Dative

$$
\text { non-fused forms fused forms phonetic transcription }
$$
1pl. ag.
[hìmṇe: ] ([hìm ne: ]) 'we [did]'
2pl. ag.
[tımṇe: $]([\mathrm{t} \Lambda \mathrm{m}$ ne: $])$ 'you [did]'
1pl. dat.

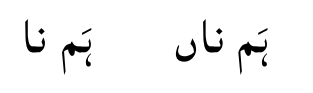

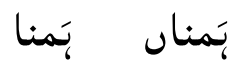
[hìmṇa: ] (hìm na: ] ] 'to us'
2pl. dat.

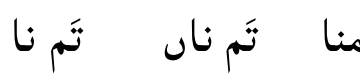
تَمنان
$[\mathrm{t} \Lambda \mathrm{mṇa:}]([\mathrm{t} \Lambda \mathrm{m}$ na: $])$ 'to you'

The agentive forms shown in Table 31 are standard per the spellings of their Urdu equivalents. All eight of the dative spellings shown are possible in materials produced in 
Indian-administered Kashmir, while in Pakistan and Pakistan-held Kashmir the two rightmost spellings are prescribed and employed by Sabir Afaqi (1995:155). The total variation for each of the first and second persons derives from connecting the dative postposition $/ \mathrm{n} \overline{\mathrm{a}} /$ to the pronoun versus writing it separately, and writing $/ \mathrm{n} \overline{\mathrm{a}} / \mathrm{with}$ nun gunno versus writing it without nun gunno.

Standardization of dative spellings depends, then, both on the standardization of a spelling for $/ \mathrm{n} \bar{a} /$ and a decision about whether to join or separate $/ \mathrm{n} \bar{a} /$ and the pronoun. Against joining is the fact that it introduces additional forms without conveying anything that is not already conveyed by the separated spellings which must be used whenever other words intervene. The forms thus introduced are not so readily 'syllabified' by the new reader/writer. In other words, joining complicates the literacy task without contributing any corresponding benefit.

In favor of joining is the possibility that it might provide a visual clue that assists Eastern readers in interpreting their own unique pronunciation, itself a contraction of sorts (cf. 2.5.3), without steering Western readers away from their own pronunciation. The latter might happen if Eastern phonetic spellings involving retroflex nun were standardized; fortunately such spellings are not in use. The potential of any such benefit for Eastern readers is diminished, however, by the existence of standard, non-fused spellings for the first and second person plural agentive forms, which involve the same pronunciation issues (note the phonetic transcriptions in Table 31). 


\section{$\underline{\text { Singular Oblique Forms }}$}

The spellings for singular oblique pronominal forms are shown in Table 32.

Table 32. Spellings for Singular Oblique Pronouns

(first and second person are shown with dative case)

$$
\text { dominant variant pronunciation }
$$

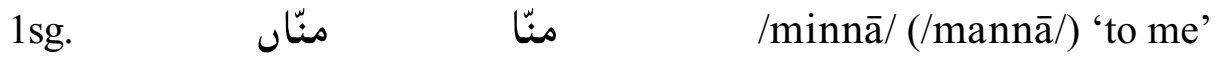

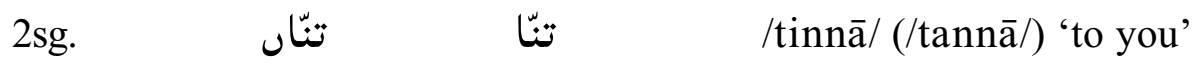

3sg. prox. /is/

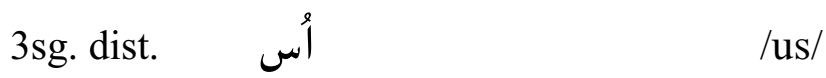

The first and second person singular forms shown in Table 32 are written as fused, because the stems /min-/ (/man-/) and /tin-/ (/tan-/) cannot occur in isolation. The spellings shown for these stems achieve neutralization of variation between Western and Eastern pronunciations (through omission of zabbar and zer, respectively). The third person singular forms shown in Table 32 are standard in Gojri per their Urdu spellings.

The spelling variation observed for the first and second person singular forms reflects the two spellings of the dative postposition /nā/ (see 5.3.3), Standardizing for the spelling of /nā/ would entail adoption of the variants in Table 32, given a commitment to consistently represent morphological affixes. This would have the added advantage of avoiding the visual ambiguity between the inherently nasal oblique plural suffix $/-\overline{\mathbf{a}} \sim /$ and the final two letters of the dominant spellings. 
In Western literacy materials, the contracted third singular dative forms, /isā $\sim$ and /usā $\sim$, and agentive forms, /ise / and /use /, can be written as fused according to their pronunciations to reflect the suffixation of these postposition allomorphs; intervening words are not allowed.

The first and second singular oblique stems /min-/ and /tin-/ also occur with the ablative postposition /te/ in both forms of Hazara Gojri. This postposition, however, is normally written تيب/te / per its pronunciation in Kashmir. Gujars in Pakistan proper could use the spelling تتع/te/, and thus مِنته /minte/ 'from me' and تِنته /tinte/ 'from you', in their own primary literacy materials. The former spelling, which is the better candidate for standardization, has the advantage of dissimilarity with the highfrequency particle ${ }^{-} / \mathrm{t} \varepsilon /$ 'and, then', and the disadvantage of being identical with the second singular agentive تيب/te /, whereas the situation is exactly opposite for a Hazara spelling (less the zabbar on $/ \mathrm{t} \varepsilon /$ ).

\section{Third Person Plural Oblique Forms}

The spellings for third person plural oblique pronominal forms are shown in Table 33. Table 33. Spellings for Third Person Plural Oblique Forms

bare suffixed (dominant) suffixed (variant) pronunciation
3pl. prox.
إنـهاu
إنهاu
/ín/ /ínā /
3pl. dist.

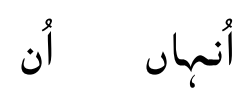
اُنهان
/ún/ /únā / 
In Table 33, the suffixed forms show the oblique plural suffix $/-\overline{\mathrm{a}} \sim /$. The spellings for the bare or non-suffixed third person plural oblique forms are identical to those for their Urdu equivalents and are therefore used universally in Gojri. The variation evident for the suffixed forms is due to variation in Urdu, where the choti he spelling is preferred to the do chasmi he spelling despite the fact that the latter 'reflects the phonology more accurately' (Schmidt 1999:22). The same could be said for Gojri, since do chasmi he following a voiced consonant normally indicates high tone on the preceding short vowel (cf. 3.2.2.5.2), whereas the choti he spelling does not so correspond to the pronunciation. Both spellings occur in materials produced in Indian-administered Kashmir, while only the dominant spelling is used on the Pakistan side. If the choti he spelling should become standardized on account of its dominance in Urdu, it would need to be treated as a sight word in primary Gojri literacy materials.

\section{First and Second Person Possessive Adjectives}

The spellings for first and second person possessive adjectives are shown in Table 34 .

Table 34. Spellings for First and Second Person Possessive Adjectives (shown with nominative masculine singular agreement)

$$
\text { dominant variant pronunciation }
$$

$1 \mathrm{sg}$.

ميرو

/mers/ 'my'

$2 \mathrm{sg}$.

تيرو

/ters/ 'your'

$1 \mathrm{pl}$.

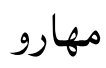

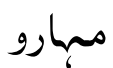

/mà̀ro/ 'our'

$2 \mathrm{pl}$.

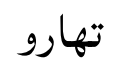

/thà̀rs/ 'your' 
The spellings for the singular forms in Table 34 are appropriated from spellings of their identical Urdu stems, and are used universally. The second person plural spelling is also universal, and its under-representation of low tone does not seem to create any ambiguity.

The first person plural has two common spellings. The dominant spelling represents low tone with do chasmi he, per the way most low-tone words beginning with stops are written in the Urdu-based approach advocated by the Cultural Academy in Srinagar. This offers the added benefit of symmetry with the second person plural spelling. The variant spelling represents low tone with choti he, consistent with the approach of those in Pakistan and Pakistan-administered Kashmir. The standardization of the spelling of this form hinges on resolution of the broader problem of indigenous low-tone words not related to de-aspiration, for which both do chasmi he and choti he can unambiguously represent underlying low tone ('lexical L'; see the third subsection in 3.2.2.6).

\subsubsection{Western Present Auxiliary and Inflections of /hò-/ 'be'}

I recommend that the Western present auxiliary, $/ \varepsilon /$, which is constant for all persons and numbers (cf. 4.2.1.1.5), be written as ${ }^{\prime} \_$and learned as a sight word per the Urdu and Eastern Gojri singular form, rather than spelled according to its own pronunciation, which would yield

The spelling of the Western form of the verb be is more complicated, since the stem /hò-/ 'to be' survives only in the lower-frequency first singular. There are at least five possible spellings for the second and third person form, /wغ̀ / [ plural spellings would be identical save for the PC suffix):

(1) وهـ a phonemic spelling by analogy with the way most low-tone words are written in an Urdu-based approach to Gojri (other than those beginning with $/ \mathrm{h} /$ ); 
(2) , the Eastern spelling of the full verb form, which could be taught as a sight word in which the first two letters are 'silent';

(3) , the spelling of the Eastern contracted form that occurs in some Academy literature (presumably its pronunciation is also [v̌̌:], as in Kaghani Gojri);

(4) و و , which is written without any tone marking so as to match the second syllable of the Eastern form (giving the appearance of a contraction); and

(5) , in which choti he indicates low tone and the first two characters correspond to the spelling of the historic (and Eastern and Urdu) stem /hò-/ 'to be', albeit with a different phonetic interpretation.

In my opinion, maintenance of word shape is primary and tone marking is secondary. At some point a body of literate Western stake-holders can commit to a solution that best accords with their own objectives, but perhaps adopting whatever form is standardized for the homophonous Eastern contracted form would be best (I believe that the third and fourth spellings are presently in use).

\subsubsection{Treatment of Loan Words}

All Persian and Arabic roots that retain some resemblance to their basic phonetic shape in spoken Gojri are written as per their spellings in Urdu, regardless of conformity to Gojri conventions (the same is true of English loans, regardless of their phonetic shape in Gojri). Two examples reflecting non-conformance to Gojri spelling patterns are شبهاد /šâdd/ 'witness' (contra the pattern documented in 3.2.2.5.1) and بـ بـ /beztī/ 'insult' (cf. Urdu/be izatī/). 
This practice is universal, to my knowledge, since such spellings are familiar to writers and make Gojri text readily accessible to Urdu-literate Gujars. Unique Gojri spellings for loan vocabulary would significantly complicate the transitional literacy task, as students would be required to learn two spellings for every loan word.

A minor caveat to the above is the replacement of the choti he endings of masculine Perso-Arabic nouns (and Urdu, cf. Schmidt 1999:3) with Gojri AC and case-marking suffixes, regardless of homophony between Gojri plural and original singular forms. Thus, the Gojri spellings of the Perso-Arabic قاعده (qāyda/ in Urdu) 'primer' are قاعدو /kāydo/ 'primer' and قاعدا/kāydā/ 'primers'. Similarly, the Gojri spellings of the PersoArabic قصّم (qissa/ in Urdu) 'story' are قصّو /kisso/ 'story' and قصّا /kissā/ 'stories'. The replacement rule does not apply when the Urdu pronunciation is retained in the Gojri nominative, for example, بادشاه/bādšá// (/bāčấ/) 'king’. This convention, while followed inconsistently at present, may reduce the potential for ambiguous interpretations.

\subsection{Concluding Reflections}

When weighed in total, the linguistic and sociolinguistic obstacles to the standardization of Gojri are minimal, while the political barriers remain formidable. At present, printed Gojri materials do not even cross the Line of Control separating Indianadministered Kashmir from Pakistan-administered Kashmir, and thus the goal of developing a literary standard seems of little consequence. But political situations change, and Gujars will benefit by taking a long-term view. Meanwhile, the goal of universal literacy can be pursued aggressively on both sides. I have argued, in accord with the 
majority of Gujar language developers, that an Urdu-based orthography for Gojri, one slightly favoring Western pronunciation and Eastern grammar, is a key to achieving both of these goals.

It remains for all alternative orthographic solutions to be tested with new readers and Urdu-literates alike in representative locations. Ideally, such testing would be conducted by decision-makers who could translate their findings into sound proposals that will meet with acceptance. The prospects for coordinating this or any other effort between communities on both sides of the Line of Control are bleak at the moment, as cross-border travel is banned and developers fear that cross-border correspondence might raise suspicions of collaboration with the enemy. New channels of communication could be developed over the Internet, however, between the elites of both areas. From the standpoint of both the standardization and literacy goals, the truly urgent communication matter is to promote Gojri writing among Urdu literates at the grass-roots level, not to fix spellings in the short term. My hope is that awareness of foreign interest in Gojri writing, rather than producing a paralyzing consciousness of incorrect spelling, will stimulate Gujars to take a greater interest in writing their own language - an emerging literary language in South Asia. 


\section{APPENDIX A}

\section{ABBREVIATIONS AND DATA PRESENTATION}

1. List of Abbreviations and Symbols

1

2

$2 / 3$

3

$\mathrm{ABL}$

$\mathrm{AC}$

Adj P

null, no phonetic form

first person

second person

second and third person

third person

ablative

adjectival concord

adjective phrase

ADV

adverbial participle

Adv

adverb

AG, Ag, ag

Aux

agentive

auxiliary

C

consonant

CAUS

causative

CONT

continuous

$\mathrm{CP}$

conjunctive participle

DAT, Dat, dat

dative

Dem

demonstrative

DIST, dist

distal

E

Eastern

EMPH

emphatic

$\mathrm{F}$, fem

FUT, fut

feminine

future

GEN, Gen

genitive

Gen P

genitive phrase

$\mathrm{H}$

HON

high (pitch)

honorific

IMPFV

imperfective

INDEF, indef

indefinite

IMPV

imperative 


\begin{tabular}{|c|c|}
\hline INF & infinitive \\
\hline INFL & inflectional (marker) \\
\hline interr & interrogative \\
\hline intrans & intransitive \\
\hline IPA & International Phonetic Alphabet \\
\hline $\mathrm{L}$ & low (pitch) \\
\hline lit. & literally \\
\hline LOC, Loc & locative \\
\hline$\mu$ & mora \\
\hline $\mathrm{M}$, masc & masculine \\
\hline $\mathrm{N}$ & noun \\
\hline NEG, Neg & negative \\
\hline NOM, Nom & nominative \\
\hline NP & noun phrase \\
\hline OBL & oblique \\
\hline PASS & passive \\
\hline $\mathrm{PC}$ & personal concord \\
\hline PERF & perfective \\
\hline PFP & perfective participle \\
\hline PL, pl & plural \\
\hline PRES & present \\
\hline PROX, prox & proximate \\
\hline Quant & quantifier \\
\hline REFL & reflexive \\
\hline REL & relative \\
\hline SG, sg & singular \\
\hline QUOT & verbal quotation marker \\
\hline$\sigma$ & syllable \\
\hline trans & transitive \\
\hline V & verb \\
\hline $\mathrm{V}$ & vowel \\
\hline VOC & vocative case marker \\
\hline VP & verb phrase \\
\hline $\mathrm{vd}$ & voiced \\
\hline W & Western \\
\hline w/ & with \\
\hline
\end{tabular}




\section{Data Presentation}

Throughout this work, unique Western-dialect lexical and morphological data are shown in parentheses to the right of Eastern forms. Wherever a single form is given, it is illustrative of both dialects. All grammatical examples not specifically identified with either the Eastern (E.) or Western (W.) dialect are illustrative of both dialects. I have tried to use such examples wherever possible. This has resulted, however, in a disproportionate number of examples with masculine subjects, due to dialect variation in the feminine agreement suffixes. Where an example is identified with one of the dialects, it varies from an equivalent utterance in the other dialect only in ways that have been described in this work, or in the choice of particular lexical items. The absence of an Eastern or Western example for any claim made for the language as a whole, therefore, reflects primarily on the limitations of space and time, not on the actual linguistic situation.

For the most part I have used the 'Standard Orientalist' transcriptional conventions for all Gojri and Urdu examples, as these conventions are predominant in the literature on Indo-Aryan (Masica 1991:xv). For phonetic transcriptions of vowels, however, I have followed the International Phonetic Alphabet (IPA). 


\section{APPENDIX B \\ 'BAKARWAL' GOJRI PHONETIC WORD LISTS}

Sub-Group Abbreviations (with respondents' seasonal locations):

ABK Allaiwal Bakarwal (respondents winter near Haripur, summer near Naran)

AMJ Allaiwal Muhajar Bakarwal (respondents winter near Khanpur, summer in Deosai)

KBK Kaghani Bakarwal (respondents winter near Kawai, summer near Besal above Naran)

KMJ Kunhari Muhajar Bakarwal (respondents winter near Jhelum, summer in Murree)

1. body

ABK but / 'jusəm

AMJ 'b $\mathrm{d} d ə n$

KBK but / 'jusom

KMJ 'b^dən

4. face

$\mathrm{ABK} m \hat{u}^{\sim}$

$\mathrm{AMJ}$ mû

KBK mû

KMJ mû

7.nose

ABK $\mathrm{n} \Lambda \mathrm{k}$

AMJ $\mathrm{n} \Lambda \mathrm{k}$

KBK $\mathrm{n} \Lambda \mathrm{k}$

$\mathrm{KMJ} \mathrm{n} \Lambda \mathrm{k}$
2. head

SIr

SIr

SIr

SIr

5. eye

$\Lambda \mathrm{k}^{\mathrm{h}}$

$\Lambda \mathrm{k}^{\mathrm{h}}$

$\Lambda \mathrm{k}^{\mathrm{h}}$

$\Lambda \mathrm{k}^{\mathrm{h}}$

8. mouth

$m \hat{u}^{\sim}$

$m \hat{u}^{\sim}$

mû

mû
3. hair

ba:!

bal

ba:!

ba:l

6. ear

$\mathrm{k} \Lambda \mathrm{n}$

$\mathrm{k} \Lambda \mathrm{n}$

$\mathrm{k} \Lambda \mathrm{n}$

$\mathrm{k} \Lambda \mathrm{n}$

9. teeth

$\mathrm{d} \Lambda \mathrm{nd}$

$\mathrm{d} \Lambda \mathrm{nd}$

$\mathrm{d} \Lambda$ nd

$\mathrm{d} \Lambda \mathrm{nd}$ 
10. tongue

11. breast $(\sim$ chest $)$

12. belly

ABK $\breve{j} \hat{i} b$

'sino

ḍ̌

AMJ ǰîb

'sino

ḍẹd

KBK ǰ̂̂b

'sino

ṭ̌̆

KMJ ̌̌̂ib

'sino

ț̣̌

13. arm

14. elbow

15. palm

ABK bâ

AMJ bâ

KBK bâ

KMJ bâ

'kuṇi

't

'kuṇi

't $\Lambda$ li

'kuṇi

't $\Lambda$ li

'kuṇi

't

16. finger

17. fingernail

18. leg

ABK ' $\Lambda$ ygəli

nôว

țng

AMJ ' $\Lambda$ ygəḷi

nô

thing / $1 \Lambda \mathrm{t}$

KBK ' $\Lambda$ ygəli

nôว

tıyg

KMJ ' $\Lambda$ ygə!̣i

nû

ǰ̂ng

19. skin

20. bone

21. heart

ABK 'čsməri

hìdí

dil

AMJ 'čamərị

hìdí

dil

KBK 'čsmorịi

hìḍí

dil

KMJ 'č

hìḍí

dil

22. blood

23. urine

24. feces

ABK $\mathrm{r} \Lambda \mathrm{t}$

nIks mut

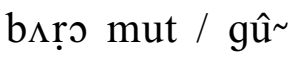

AMJ $r \Lambda t$

niks mut

hìgńn / gû̃

KBK $\mathrm{r} \Lambda \mathrm{t}$

niks mut

bıṛo mut

KMJ $\mathrm{r} \Lambda \mathrm{t}$

nIko mut

gû̃ 
25. village

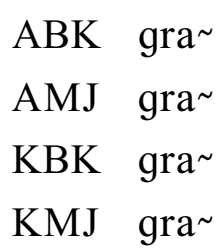

28. door

ABK bûs

AMJ bûo

KBK bûs

KMJ bûs

31. mortar

ABK '1 $1 \wedge$ ygəri

AMJ '1 1 ygəri

KBK '1 1 ygəri

KMJ 'lıygəri

34. knife (pocket/generic)

ABK 'kaču / 'čch Urìi

AMJ 'čākū / 'čch Ữi

KBK 'kaču / 'čh $u \overline{r i}$

KMJ 'kaču / 'č ${ }^{h} u \overline{r i}$

37. thread (singular)
26. house

'dero

'dero

'dero

'dero

29. firewood

'1^kəri

'1ムkəri

'1 1 kərịi

'1ムkəri

32. pestle (stone/wood)

sil'aṭo / 'molo

sil'aṭo / 'munglo / 'molo

sil'aṭo / 'mulo

sil'aṭo / 'munglo

35. axe

gwàrí

gwàrí

kwàrí

kwàrí

38. needle

'sui

'sui

'sui

'sui
27. roof

$\check{c}^{h} \Lambda t$

$\check{c}^{\mathrm{h}} \Lambda \mathrm{t}$

$\check{c}^{h} \Lambda t$

$\check{c}^{h} \Lambda t$

30. broom

bàrí

bàrí

bàrí

bàrí

33. hammer

sıṭ̂'kio / ì'th òré

$\lambda^{\prime} t^{\mathrm{h}}$ òr í

thòrí $^{\text {hó }}$

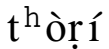

36. rope

(generic/of hair)

'rusi / 'seli

'rusi / 'seli

'rusi / 'seli

'r $\Lambda$ si / 'seli

39. cloth (cloth/clothing)

'kıpəṛ̣ / 'čị̣ $\Lambda$

'kıpəṛo / 'čirı

'kıpərọ / 'čiṛ

'kıpəṝ / 'čirı 
40. ring
ABK $\quad \Lambda \eta^{\prime}$ gut $^{h}{ }^{h}$
AMJ $\quad \Lambda \eta^{\prime}$ gut $^{h^{h}}{ }$
KBK $\Lambda \eta^{\prime}$ gut $^{\mathrm{h}} \mathrm{i}$
KMJ 'gut ${ }^{h_{i}}$

43. sky

ABK $\Lambda s^{\prime} \operatorname{man}$

AMJ $\Lambda \mathrm{s}^{\prime} \operatorname{man}$

$\mathrm{KBK} \Lambda \mathrm{s}^{\prime} \operatorname{man}$

$\mathrm{KMJ} \Lambda \mathrm{s}^{\prime} \mathrm{man}$

46. water

\begin{abstract}
ABK 'paṇi
AMJ 'paṇi

KBK 'paṇi

KMJ 'paṇi
\end{abstract}

49. lightning

ABK 'čaṛok / '1 1 ske

AMJ 'čaṛək / 'biǰli / '1 1 ske

KBK 'čaṛək / '1 1 ške

KMJ 'bıǰli / bıǰ / ' $1 \Lambda s ̌ k \varepsilon$

52. stone
41. sun

dî $\sim$

$\mathrm{d} \hat{\imath} \sim$

$\mathrm{d} \hat{\imath} \sim$

$d \hat{\imath}^{\sim}$

44. star (singular)

'taro

'taro

'taro

'taro

47. river (medium-sized)

'n $\Lambda$ di

'n $\Lambda$ di

'n $\Lambda$ di

'n $\Lambda$ di

50. rainbow

pîm

pîm

pîng

pîng

53. path

râ

râ

râ

râ
42. moon

$\check{c}_{\Lambda \mathrm{n}}$

с $\Lambda \mathrm{n}$

$\check{c}_{\Lambda} \mathrm{n}$

$\check{c}_{\Lambda} \mathrm{n}$

45. rain

'barəš / $\mathrm{m} \hat{1}^{\sim}$

'bıdəl

'b $\Lambda$ dəl

'b $\Lambda$ dəl

48. cloud

ǰ̣̌

jॅ̌r

čñr

čs̆r

51. wind

(generic/strong)
ABK 'gati

AMJ 'gaṭi

KBK 'bsṭi

KMJ 'gaṭi / 'bsṭi

â

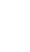

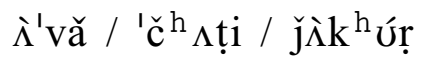

ì'vă / ' 'č ${ }^{\mathrm{h}} \Lambda \mathrm{ti} /$ jù k $\mathrm{k}^{\mathrm{h}} u ̛$ ṛ

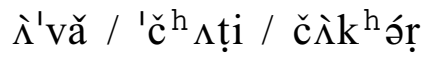

ò'vă / 'č ${ }^{h} \Lambda$ ṭi

54. sand

ret

ret

ret

ret 
55. fire

$\begin{array}{ll}\text { ABK } & \Lambda \mathrm{g} \\ \text { AMJ } & \Lambda \mathrm{g} \\ \text { KBK } & \Lambda \mathrm{g} \\ \text { KMJ } & \Lambda \mathrm{g}\end{array}$

58. mud

ABK 'čıkərọ / 'garo

AMJ 'čıkərọ

KBK 'garo

KMJ 'garo

61. tree (generic/big)

ABK 'buṭ / ruk ${ }^{\text {h }}$

AMJ 'buṭ / ruk ${ }^{h}$

KBK 'buṭ / ruk ${ }^{\mathrm{h}}$

KMJ 'buṭ / ruk ${ }^{\mathrm{h}}$

64. thorn

ABK 'kıṇḍ

AMJ 'kıṇḍo

KBK 'kıṇḍo

KMJ 'kıṇdo

67. mango

$\mathrm{ABK} \Lambda \mathrm{m}$

$\mathrm{AMJ} \Lambda \mathrm{m}$

KBK $\Lambda \mathrm{m}$

KMJ $\Lambda \mathrm{m}$
56. smoke

dù ว́

dù ว́

tù ว́

tù ó

59. dust (dust/dirt)

dùr / 'miți

dùr / 'miți

tùr / 'miṭi

tùr / 'miṭi

62. leaf

'p $\mathrm{stor}$

'p $\Lambda$ tər

'p $\Lambda$ tər

'p $\Lambda$ tər

65. flower

$\mathrm{p}^{\mathrm{h}} \mathrm{ul}$

$\mathrm{p}^{\mathrm{h}} \mathrm{ul}$

$\mathrm{p}^{\mathrm{h}} \mathrm{ul}$

$p^{h} u l$

68. banana

'kels

'kels

'kels

'kelo
57. ash

swàgó

swàgó

swàgó / č ${ }^{\mathrm{h}} \Lambda \mathrm{i}$

swàgó

60. gold

'sono

'sono

'sono

'sono

63. root

ǰ̣̂r

ǰ̣̂r

jॅ̂r

ǰ̂̀r

66. fruit

(generic/berries)

$\mathrm{p}^{\mathrm{h}} \Lambda \mathrm{l} / \mathrm{I}^{\mathrm{m}} \mathrm{e} \mathrm{v}$

$\mathrm{p}^{\mathrm{h}} \Lambda \mathrm{l} / \mathrm{I}^{\mathrm{m}} \mathrm{v} \mathrm{v}$

$\mathrm{p}^{\mathrm{h}} \Lambda$ ! / 'me vo

frut / 'me vo

69. wheat (husked)

'kaṇək

'kaṇək

'kaṇək

'kaṇək 
70. millet (husked)

71. rice (husked)

72. potato

*unfamiliar to respondents

ABK 'baǰrs
AMJ 'baǰrs
KBK 'baǰrs
KMJ 'baǰrs

73. eggplant

*unfamiliar to respondents

ABK 'bengự

AMJ 'bengə̣n

KBK 'bengun

KMJ ' $\mathrm{p} \Lambda \underline{t}^{\mathrm{h}} \Lambda$

76. turmeric

ABK hřld

AMJ hřld

KBK hřld

KMJ h ̌̌ld

79. cauliflower

ABK $p^{\mathrm{h}} \mathrm{ul}$ 'gopi

AMJ 'gobi

KBK $p^{\mathrm{h}} \mathrm{ul}$ 'gobi

KMJ 'gobi

82. oil

ABK tel

AMJ tel

KBK tel

KMJ tel 'čawu!

'čavıl

'čaw!

'čavul

74. groundnut

$\mathrm{mo}^{\sim} \mathrm{p}^{\mathrm{h}} \Lambda \mathrm{li}$

mong ' $\mathrm{p}^{\mathrm{h}} \Lambda \mathrm{li}$

mo ${ }^{\prime} p^{h} \Lambda l i$

mung ' $\mathrm{p}^{\mathrm{h}} \Lambda \mathrm{li}$

77. garlic

$\mathrm{t}^{\mathrm{h}} \mathrm{um}$

$\mathrm{t}^{\mathrm{h}} \mathrm{um}$

$\mathrm{t}^{\mathrm{h}} \mathrm{u}: \mathrm{m}$

$\mathrm{t}^{\mathrm{h}} \mathrm{u}: \mathrm{m}$

80. tomato

to'mațr

to'maṭor

to'maţor

to'maṭor

83. salt

lun

luṇ

luṇ

lun
${ }^{\prime}$ slu

${ }^{\prime} \Lambda 1 \mathrm{u}$

'alu

'alu

75. chili

'm $\Lambda$ rəč

'murč

'm $\mathrm{m}$ rəč

'm $\mathrm{rr \partial č}$

78. onion

piaz / piaj

piaj

peaz

piaz / 'gıṇ̣̣

81. cabbage

bsnd 'gopi

bsnd 'gobi

bsnd 'gobi

bsnd 'gobi

84. meat

mas

mas

mas

mas 
85. fat
ABK 'č $\Lambda \mathrm{rbi}$
AMJ 'č $\Lambda$ rbi
KBK 'č $\Lambda$ rəbi / mînj̆
KMJ 'čsrəbi

88. egg

\begin{abstract}
ABK ' $\Lambda$ ṇţ̣ṛo
AMJ ' $\Lambda$ ṇtorọ

KBK 'aṇṭọ̣o

KMJ 'aṇṭọ̣o
\end{abstract}

91. milk

ABK dûd

AMJ dûd

KBK dûd

KMJ dûd

94. goat

ABK 'b kəri $^{2}$

AMJ 'b $\Delta$ kəri

KBK 'b $\Lambda$ kəri

KMJ 'b $\Lambda k^{h} \partial \bar{r} i$

97. monkey

ABK 'bujəṇ๊

AMJ 'buj̄ṇo

KBK 'buj̄ṇı

KMJ 'buj̄ṇ๊
86. fish

'ms čh $\mathrm{i}$

'm $\Lambda \check{c}^{h} \mathrm{i}$

'ms č ${ }^{\mathrm{h}} \mathrm{i}$

'msč ${ }^{\mathrm{h}} \mathrm{i}$

89. cow

ga

$\mathrm{ga}^{\sim}$

$\mathrm{ga}^{\sim}$

$\mathrm{ga}^{\sim}$

92. horns

seng

seng

sing

seng

95. $\operatorname{dog}$

'kuto

'kuts

'kuts

'kuts

98. mosquito

'm $\Lambda \check{c}^{h} \partial r$

'm $\Lambda \check{c}^{\mathrm{h}} \partial \mathrm{r}$

'ms č h $\partial r$

'mıč $\check{c}^{\mathrm{h}} \partial \mathrm{r}$
87. chicken (generic)

'kukur

'kukur

'kukur

'kukur

90. buffalo

mĚs

měs

měs

mĚs

93. tail

(generic/of sheep)

'dumur

'dumur

'dumự / 'pučh ${ }^{\mathrm{h}}$ ə̣i

'dumur

96. snake

$\mathrm{s} \Lambda \mathrm{p}$

$\mathrm{s} \Lambda \mathrm{p}$

$\mathrm{s} \Lambda \mathrm{p}$

$\mathrm{s} \Lambda \mathrm{p}$

99. ant

píl’̀

píl’̀

pílà

pílò 
100. spider

ABK ̌u'lâ

AMJ ̌u'lâ

KBK bᄉ'bîo

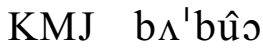

103. woman

ABK dèṇí

AMJ deàníi

KBK teàṇí

KMJ 'beṭi

106. mother

ABK ma

AMJ ma

KBK ma

KMJ ma

109. older sister

ABK bıṛi bén

AMJ bıṛi bén / 'Idi

KBK bıṛi bén

KMJ bıṛi bén

112. daughter

ABK dř

AMJ dř / 'beṭki

KBK tř

KMJ tř
101. name

na

na

na

na

104. child

'jatuk / 'b

'jatuk / 'b $\Lambda$ čs

'ǰstk / 'b $\Lambda$ čs

'jatuk / 'b $\mathrm{c} c ̌ s$

107. older brother

(not for address)

b^ṛo băi

bıṛo băi

bıṛo păi

bıṛo pǎi

110. younger sister

nıki bện

nıki bệ

nıki bệ

nıki bệ

113. husband

'ǰṇo / 'dẹs àḷó

'

'јૅ

' ’̌n
102. man

(man/person)

'ǰıṇ๐ / 'admi

'јૅ

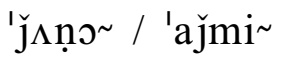

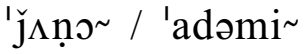

105. father

bap

bap

baip

ba:p

108. younger brother (not for address)

nıko bǎi

nıko bǎi

nıko pǎi

niks pǎi

111. son

put

put

puit

puit

114. wife

'ḍers àlíi / dèṇí deàṇí /'ḍer àḷí/ 't $\Lambda$ bri 'ḍer $\Lambda$ aḷi / teàníi zı'nani / 't $\Lambda$ bri 
115. boy

ABK 'lự̣

AMJ 'lự̦

KBK 'lựo

KMJ 'lựo

118. night

ABK rat

AMJ rat

KBK ra:t

KMJ ra:t

121. evening

ABK no'ma $\check{\text { Š }}{ }^{\sim}$

AMJ no'ma $\check{\text { Š }}{ }^{\sim}$

KBK no'ma $\sim{ }^{\prime} \Lambda^{\sim}$

KMJ šam

124. tomorrow

ABK 'dinn

AMJ 'din $\Lambda^{\sim}$

KBK 'din $\Lambda^{\sim}$

$\mathrm{KMJ} \operatorname{din} \Lambda^{\sim}$

127. year

ABK sal / 'sım ^

AMJ sal

KBK sal

KMJ sal
116. girl

117. day (daytime)

'bețki

'bețki

'bețki

'bețki

119. morning

'suba

niki lo

'v $x$ xti

niki b

122. yesterday

$\mathrm{k} \Lambda \mathrm{l}$

$\mathrm{k} \Lambda \mathrm{l}$

$\mathrm{k} \Lambda \mathrm{l}$

$\mathrm{k} \Lambda 1$

125. week

hìftó

hìftó

hìftó

$\Lambda \underline{t}^{\mathrm{h}}$ teàr $\Lambda$

128. old

pur'aṇo

pur'aṇo

pur'aṇo

pur'aṇo diàríi

diàrí

deàṛí

teàrí

120. noon

du'pâr

do'pâr

do'pârr

d $\Lambda$ 'pâr

123. today

$\Lambda \check{j}$

$\Lambda \check{j}$

$\Lambda \check{j}$

$\Lambda \check{j}$

126. month

mìnó

mìnó

mìnó

mìnó

129. new

'no o

'no o

'no

'no o 
130. good

ABK hīčhó / 'čsygo / sóṇ̀̀

AMJ hǐčhó / 'čsygo / sóṇ̀̀

KBK hìčhó / 'čsygo / sóṇ̀̃

KMJ hìčhó / 'čsygo / sóṇ̀̀

133. dry

ABK 'suks

AMJ 'suko

KBK 'suko

KMJ 'suko

136. hot

ABK 't $\Lambda$ piə/'t $\Lambda$ tə/'g

AMJ 't $\Lambda$ ti

KBK 'tıpes vo / 'g

KMJ 'tıpes $\beta$ о

139. left

ABK ${ }^{\prime} \mathrm{k}^{\mathrm{h}} \Lambda$ bo

AMJ ' $\mathrm{k}^{\mathrm{h}} \Lambda$ bo

$\mathrm{KBK} \quad{ }^{\prime} \mathrm{k}^{\mathrm{h}} \Lambda \mathrm{bo}$

KMJ ' $\mathrm{k}^{\mathrm{h}} \Lambda$ bo

142. big

ABK 'b $\mathrm{s}$ ṛo

AMJ 'b $\mathrm{s}$ ro

KBK 'b

KMJ 'b
131. bad

'msndo

'mındo

'msndo

'mındo

134. long

'1 1 mo

'1 1 mo

'1 $1 \Lambda \mathrm{m} \mathrm{o}^{\sim}$

'1 $1 \mathrm{~m} \jmath^{\sim}$

137. cold

'ṭ ${ }^{\mathrm{h}} \Lambda$ ṇ̣̣o

't ${ }^{\mathrm{h}} \Lambda$ ṇdo

'th ${ }^{\mathrm{h}} \Lambda$ ṇdo

'th ${ }^{\mathrm{h}} \Lambda$ ṇdo

140. near

'neṛ

'nere

'nere

'nere

143. small

'niko

'niko

'niko

'niko
132. wet

bìǰío

bì ǰío

pìjéo

pìjéo

135. short/little/low

'čh oṭ̣/'nıks/'mındro

'čh oṭo/'nıko/'m ${ }^{\mathrm{h}}$ ndəro

'čh oṭo/'nıks/'mındro

'nıko/'nıko/'m $\Lambda$ ndro

138. right

's $\Lambda$ jo

's $\Lambda$ jo

's $\Lambda$ jo

's $\Lambda$ jo

141. far

dur

dur

dur

dur

144. heavy

bàró

bàró

pàró

pàró 
145. light

ABK hòló / lô ko
AMJ hòló
KBK họ̀ó / lô ko
KMJ hòló

148. white

ABK 'čițo

AMJ 'čițo

KBK 'čițo

KMJ 'čițo

151. one

(only the first variant used in counting)

ABK ek / Ik

AMJ ek

KBK ek / ik

KMJ ek / ik

154. four

ABK čar

AMJ čar

KBK čar

KMJ čar

157. seven

ABK s st

AMJ $s \Lambda t$

KBK $s \Lambda t$

KMJ $s \Lambda t$
152. two

146. above

'upor

'upur

'یpor

' $\Lambda$ pur

149. black

'kạ̣

'kaḷ

'kaḷ

'kaḷ
147. below

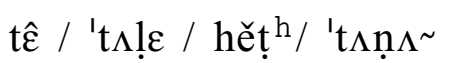

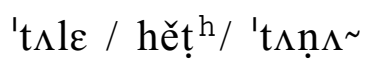

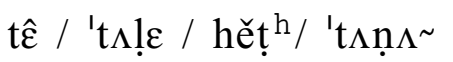

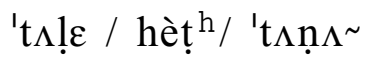

150. red

'r $\Lambda$ to

'ruto

'r $\Lambda$ to

'ruto

153. three $\operatorname{tr} \varepsilon$

tre

tre

$\operatorname{tr} \varepsilon$

156. six

$\check{c}^{h} \mathrm{e}$

$\check{c}^{h} \mathrm{e}$

$\check{c}^{h} \mathrm{e}$

$\check{c}^{h} \mathrm{e}$

159. nine

no

no

no

no 
160. ten

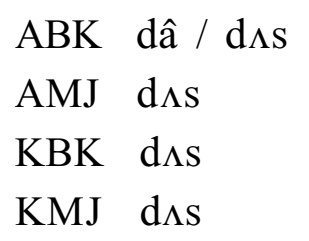

163. twenty

ABK bî

AMJ bî

KBK bî

KMJ bî

166. what

ABK ke

AMJ ke

KBK ke

KMJ ke

169. how many

ABK 'kitən $\Lambda^{\sim}$

AMJ 'kItən $\Lambda^{\sim}$

KBK 'kiton $\Lambda^{\sim}$

KMJ 'kitən $\Lambda^{\sim}$

172. that (fem. / masc.)
161. eleven

'yar $\Lambda^{\sim}$

'yars

'yar $\Lambda^{\sim}$

'yar $\Lambda^{\sim}$

164. one hundred

so

so

so

so

167. where / to where

kit / 'king $\Lambda$

kit / 'kıng $\Lambda$

kit / 'kıng $\Lambda$ / kîn $\sim$

kit / 'king $\Lambda$

170. what thing

ke š $\varepsilon$

ke še / ke čiz

ke š $\varepsilon$

ke čiz

173. these

yê

yê

yê

yê
162. twelve

'bar $\Lambda^{\sim}$

'bars

'bar $\Lambda^{\sim}$

'barı

165. who

kon

kon

kon

kon

168. when

kıd

$\mathrm{k} \Lambda \mathrm{d}$

$\mathrm{k} \wedge \mathrm{d}$

$\mathrm{k} \Lambda \mathrm{d}$

171. this (fem./ masc.)

ŷิ / yô

ŷิ / yô

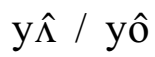

ŷ̂ / yô

174. those

vê

vê

vê

vê 
175. same

ABK ek r $\Lambda$ yg / 'brabur

AMJ ek šan / 'brabur

KBK ek r $\Lambda$ yg / 'brabur

KMJ ek rıyg / 'brabur

178. broken

ABK ' $p^{\text {h}} u t ̣$

AMJ ' $\mathrm{p}^{\mathrm{h}} u t ̣$

KBK ' $\mathrm{p}^{\mathrm{h}} u t$ tes vo

KMJ 'tuṭo $\beta$ o

181. all

ABK 'sar $\Lambda$

AMJ 'sar $\Lambda$

KBK 'sar $\Lambda$

KMJ 'sar $\Lambda$

184. [he is] hungry

ABK bùk ${ }^{\mathrm{h}}$ ó

AMJ bùk ${ }^{\mathrm{h}} \dot{s}$

KBK pùk ${ }^{\mathrm{h}} \mathbf{s}$

KMJ pùk ${ }^{\mathrm{h}} \mathbf{s}$

187. sleep!
ABK so
AMJ so rô
KBK so
KMJ so rô

176. different

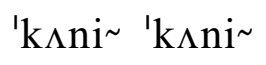

$\mathrm{b} \Lambda \mathrm{k} b \Lambda \mathrm{k}$

'kıni 'kıni

'k $\Lambda \mathrm{ni}^{\sim}$ 'k $\Lambda \mathrm{ni}^{\sim}$

179. few ( a little)

't ${ }^{\text {h }}$ oṛo / gřt

't ${ }^{\mathrm{h}}$ oṛ / g ǧ̀t

'th oṛ / kšt

'th oṛ / kñ ț

182. eat!

$\mathrm{k}^{\mathrm{h}} \mathrm{a}$

$\mathrm{k}^{\mathrm{h}} \mathrm{a}$

$\mathrm{k}^{\mathrm{h}} \mathrm{a}$

$\mathrm{k}^{\mathrm{h}} \mathrm{a}$

185. drink!

pi

pi

pi

pI

188. lay down!

pe rô / $1 \Lambda \mathrm{m} \jmath^{\sim}$ hǒ

$\mathrm{p} \varepsilon \mathrm{rô}$

$1 \Lambda \mathrm{m} \vartheta^{\sim}$ hǒ

1ムm $\sim$ hǒ
177. whole ( entire)

'saro/'sabut/'salım/'puro

'sars/'sabut/'salım/'purs

'sars/'salım/'purs

'saro/'sabut/'puro

180. many

muč

muč

muč

muč

183. [the dog] bit

$\mathrm{k}^{\mathrm{h}} \mathrm{a}$ lio / $1 \Lambda \mathrm{r}$ gio

$\mathrm{k}^{\mathrm{h}} \mathrm{a}$ lio

$\mathrm{k}^{\mathrm{h}} \mathrm{a}$ lis / $1 \Lambda \mathrm{r}$ gis

$\mathrm{k}^{\mathrm{h}} \mathrm{a}$ lis

186. [he is] thirsty

tIs $1 \Lambda \mathrm{g} \varepsilon$

tis $1 \Lambda \mathrm{ge} / \mathrm{t} \Lambda$ 'sayo

tis $1 \Lambda \mathrm{ge}$

tIs $1 \wedge \mathrm{g} \varepsilon$

189. sit!

bes

bes rô

bes

bes ja 
190. give!

ABK de

AMJ de

KBK dê

KMJ de

193. kill!

ABK mar

AMJ mar

KBK mar

KMJ mar

196. run!

ABK dor

AMJ dor

KBK dor

KMJ dor

199. speak! / say!

ABK bol / kô

AMJ bol / k̂̂

KBK bol / k̂े

KMJ bol / kô

202. I

ABK hŭ

AMJ hǔ

KBK hŭ

KMJ hǔ
191. burn [wood]!

sar

sar / bal

sar

bal

194. fly!

vạ

uḍ

uḍ

vạ

197. go!

$\check{c}_{\Lambda} 1$

čsl

čsl

$\check{c}_{\Lambda} 1$

200. listen!

suṇ

sự

sun

sun

203. you (informal)

to

to

to

tu
192. [the man] died

$\mathrm{m} \Lambda \mathrm{r}$ gis

$\mathrm{m} \Lambda \mathrm{r}$ gio

$\mathrm{m} \Lambda \mathrm{r}$ gio

$\mathrm{m} \Lambda \mathrm{r}$ gio

195. walk!

țor

țor

țor

țor

198. come!

a / a ja

a

a / a ja

'Inga a

201. look!

$\mathrm{dek}^{\mathrm{h}} /$ hěr $\operatorname{dek}^{\mathrm{h}} /$ hěr hěr / dek ${ }^{\mathrm{h}}$

$\mathrm{dek}^{\mathrm{h}}$

204. you (formal)

to

$\mathrm{t} \Lambda \mathrm{m}$

$\mathrm{t} \Lambda \mathrm{m}$

$\mathrm{t} \Lambda \mathrm{m}$ 
205. he (dist/prox)

206. she

ABK $\beta \hat{o ̂} /$ yô

AMJ $\beta \hat{o} /$ yô

KBK ßô / yô ( ô )

KMJ $\beta \hat{o} /$ yô

208. we (exclusive)

ABK h⿱̌m

AMJ h⿱̌m

KBK ȟ̌m

KMJ h⿱八m $\mathrm{v} \hat{\Lambda} / \mathrm{y} \hat{\Lambda}$

$\mathrm{v} \hat{\Lambda} / \mathrm{y} \hat{\Lambda}$

$\mathrm{v} \hat{\Lambda} / \mathrm{y} \hat{\Lambda}$

$\mathrm{v} \hat{\Lambda} / \mathrm{y} \hat{\Lambda}$

209. you (plural)

$\mathrm{t} \Lambda \mathrm{m}$

$\mathrm{t} \Lambda \mathrm{m}$

$\mathrm{t} \Lambda \mathrm{m}$

$\mathrm{t} \Lambda \mathrm{m}$
207. we (inclusive)

$\mathrm{h} \check{\mathrm{m} m}$

$\mathrm{h} \check{\mathrm{L} m}$

$\mathrm{h} \check{\mathrm{m}} \mathrm{m}$

h ̌̌m

210. they (dist / prox)

vê / yê

vê / yê

vê / yê

vê / yê 


\section{APPENDIX C \\ GOJRI VERBAL PARADIGMS}

Tables 35-50 present one complete verbal paradigm for each of the level-tone and high-tone long vowels in which a verb stem may end (ordered from close to open, with

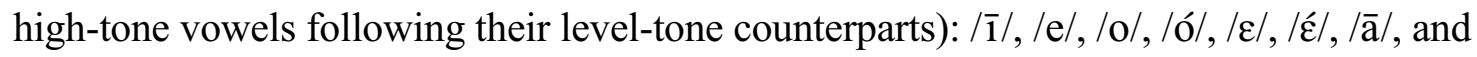
/áa (for /hò-/ 'be', the underlying tone is associated with /h/, not with the vowel). The inflections given for each verb are representative of the regular inflections of other verbs ending in the same vowel as that verb. The regular inflections for each level-tone and high-tone vowel pair are apparently identical, but for reference I have included paradigms for both members of each pair. Stem-final $/ \varepsilon /$ is attested in my data only by the irregular verb /pe-/ 'fall' given in tables 43 and 44 .

Tables 51-58 present the high-frequency verbs give, be, do, and give, whose paradigms show irregular inflections.

For each of the paradigms, unique Western forms are given in parentheses. 


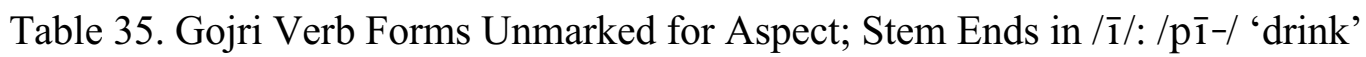

\begin{tabular}{|c|c|c|c|c|c|}
\hline & & Stem & (Tense) & $\mathrm{PC}$ & Full form \\
\hline \multirow[t]{5}{*}{ Unspecified Habitual } & $1 \mathrm{sg}$. & $\mathrm{p} \overline{1}-$ & & $-\overline{\mathrm{u}} \sim$ & $\mathrm{p} \overline{1} \overline{\mathrm{u}} \sim$ \\
\hline & $1 \mathrm{pl}$ & $\mathrm{p} \overline{1}-$ & & $-\bar{a} \sim$ & $\mathrm{p} \overline{\bar{a}} \overline{\mathrm{a}} \sim$ \\
\hline & $2 / 3 \mathrm{sg}$ & $\mathrm{p} \overline{1}-$ & & $-\varepsilon$ & $\mathrm{p} \overline{1} \varepsilon$ \\
\hline & $2 \mathrm{pl}$ & $\mathrm{p} \overline{1}-$ & & $-0(-\varepsilon)$ & $\mathrm{p} \overline{1} \supset(\mathrm{p} \overline{1} \varepsilon)$ \\
\hline & $3 \mathrm{pl}$ & $\mathrm{p} \overline{1}-$ & & $-\varepsilon^{\sim}(-\varepsilon)$ & $\mathrm{p} \overline{1} \varepsilon^{\sim}(\mathrm{p} \overline{1} \varepsilon)$ \\
\hline \multirow[t]{5}{*}{ Negated Future } & $1 \mathrm{sg}$. & $\mathrm{p} \overline{1}-$ & $-\mathrm{S}$ & $-\overline{\mathrm{u}} \sim$ & $\mathrm{p} \overline{\mathrm{i}} \mathrm{s} \overline{\mathrm{u}} \sim$ \\
\hline & $1 \mathrm{pl}$ & $\mathrm{p} \overline{1}-$ & $-\mathrm{S}$ & $-\overline{\mathrm{a}} \sim$ & $\mathrm{p} \overline{\mathbf{1}} \mathrm{s} \overline{\mathrm{a}} \sim$ \\
\hline & $2 / 3 \mathrm{sg}$ & $\mathrm{p} \overline{1}^{-}$ & $-\mathrm{S}$ & $-\varepsilon$ & $\mathrm{p} \overline{1} \mathrm{~s} \varepsilon$ \\
\hline & $2 \mathrm{pl}$ & $\mathrm{p} \overline{1}^{-}$ & $-\mathrm{S}$ & $-0(-\varepsilon)$ & pīso (pīse) \\
\hline & $3 \mathrm{pl}$ & $\mathrm{p} \overline{1}^{-}$ & $-S$ & $-\varepsilon^{\sim}(-\varepsilon)$ & $\mathrm{p} \overline{\mathbf{1}} \mathrm{s} \varepsilon^{\sim}(\mathrm{p} \overline{\mathbf{1}} \mathrm{s} \varepsilon)$ \\
\hline \multirow[t]{2}{*}{ Present Imperative } & $2 \mathrm{sg}$ & $\mathrm{p} \overline{1}-$ & & $\emptyset$ & $\mathrm{p} \overline{1}$ \\
\hline & $2 \mathrm{pl}$ & $\mathrm{p} \overline{1}-$ & & $-0\left(-\rho^{\sim}\right)$ & 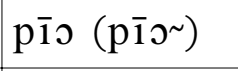 \\
\hline \multirow[t]{2}{*}{ Future Imperative } & $2 \mathrm{sg}$ & $\mathrm{p} \overline{1}^{-}$ & $-\overline{1}(-\overline{1} \sim)$ & $-\mathrm{e}$ & $\mathrm{p} \overline{1} \mathrm{e}(\mathrm{p} \overline{\mathbf{1}} \sim \mathrm{e})$ \\
\hline & $2 \mathrm{pl}$ & $\mathrm{p} \overline{1}-$ & $-\overline{1}\left(-\overline{1}^{\sim}\right)$ & $-0\left(-\jmath^{\sim}\right)$ & $\mathrm{p} \overline{1} \supset\left(\mathrm{p} \overline{\mathbf{1}} \sim \mathrm{0}^{\sim}\right)$ \\
\hline
\end{tabular}

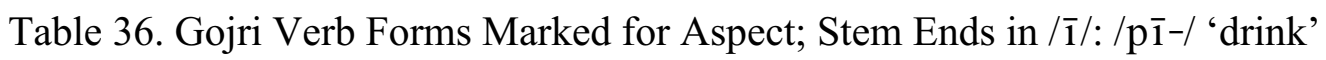

\begin{tabular}{|c|c|c|c|c|c|}
\hline & & Stem & Aspect & $\mathrm{AC}$ & Full form \\
\hline \multirow[t]{4}{*}{ Habitual (Negated) } & m.sg. & $\mathrm{p} \overline{1}-$ & $-t$ & -0 & pìto \\
\hline & m.pl. & $\mathrm{p} \overline{\mathbf{1}}^{-}$ & $-\mathrm{t}$ & $-\overline{\mathrm{a}}$ & pītā \\
\hline & f.sg. & $\mathrm{p} \overline{1}^{-}$ & $-\mathrm{t}$ & $-\overline{1}$ & $\mathrm{p} \overline{1} \mathrm{t} \overline{1}$ \\
\hline & f.pl. & $\mathrm{p} \overline{1}^{-}$ & $-\mathrm{t}$ & $-\overline{1} \sim(-\overline{1})$ & $\mathrm{p} \overline{\mathbf{1}} \mathrm{t} \overline{\mathbf{1}} \sim(\mathrm{p} \overline{\mathrm{1}} \mathrm{t} \overline{\mathbf{1}})$ \\
\hline \multirow[t]{4}{*}{ Unspecified Perfective } & m.sg. & $\mathrm{p} \overline{1}-$ & -e $(-\overline{1})$ & -0 & pīo \\
\hline & m.pl. & $\mathrm{p} \overline{1}^{-}$ & -e $(-\overline{1})$ & $-\overline{\mathrm{a}}$ & $\mathrm{p} \overline{1} \bar{a}$ \\
\hline & f.sg. & $\mathrm{p} \overline{1}^{-}$ & -e $(-\overline{1})$ & $-\overline{1}$ & $\mathrm{p} \overline{1}$ \\
\hline & f.pl. & $\mathrm{p} \overline{1}-$ & -e $(-\overline{1})$ & $-\overline{1} \sim(-\overline{1})$ & $\mathrm{p} \overline{1}^{\sim}(\mathrm{p} \overline{\mathbf{1}})$ \\
\hline
\end{tabular}


Table 37. Gojri Verb Forms Unmarked for Aspect; Stem Ends in /e/: /le/ 'take'

\begin{tabular}{|c|c|c|c|c|c|}
\hline & & Stem & (Tense) & PC & Full form \\
\hline \multirow[t]{5}{*}{ Unspecified Habitual } & $1 \mathrm{sg}$. & $1 e^{-}$ & & $-\overline{\mathrm{u}} \sim$ & $1 \overline{1} \bar{u} \sim$ \\
\hline & $1 \mathrm{pl}$. & le- & & $-\overline{\mathrm{a}} \sim$ & leā $\sim(1 \overline{1} \overline{\mathrm{a}} \sim)$ \\
\hline & $2 / 3$ sg. & 1e- & & $-\mathrm{e}$ & lec $(1 \overline{1} \varepsilon)$ \\
\hline & $2 \mathrm{pl}$ & le- & & $-0(-\varepsilon)$ & les $(1 \overline{1} \varepsilon)$ \\
\hline & $3 \mathrm{pl}$. & 1e- & & $-\varepsilon^{\sim}(-\varepsilon)$ & $1 \mathrm{e}^{\sim}(1 \overline{1} \varepsilon)$ \\
\hline \multirow[t]{5}{*}{ Negated Future } & 1 sg. & 1e- & $-s$ & $-\overline{\mathrm{u}} \sim$ & $\operatorname{les} \bar{u} \sim$ \\
\hline & $1 \mathrm{pl}$. & le- & $-s$ & $-\overline{\mathrm{a}} \sim$ & les $\bar{a} \sim$ \\
\hline & $2 / 3$ sg. & $1 e^{-}$ & $-s$ & $-\mathrm{e}$ & lese \\
\hline & $2 \mathrm{pl}$. & le- & $-s$ & $-0(-\varepsilon)$ & leso (lese) \\
\hline & 3 pl. & le- & $-s$ & $-\varepsilon^{\sim}(-\varepsilon)$ & lese $(\operatorname{les} \varepsilon)$ \\
\hline \multirow[t]{2}{*}{ Present Imperative } & $2 \mathrm{sg}$. & 1e- & & $\emptyset$ & le \\
\hline & $2 \mathrm{pl}$. & 1e- & & $-\supset\left(-\jmath^{\sim}\right)$ & leo $\left(\operatorname{lī} \rho^{\sim}\right)$ \\
\hline \multirow[t]{2}{*}{ Future Imperative } & 2 sg. & 1e- & $-\overline{1}(-\overline{1} \sim)$ & $-\mathrm{e}$ & la $\overline{1} \mathrm{e}(\mathrm{la} \overline{\overline{1}} \sim \mathrm{e})$ \\
\hline & $2 \mathrm{pl}$. & 1e- & $-\overline{1}(-\overline{1} \sim)$ & $-0\left(-0^{\sim}\right)$ & lā̄o $\left(\operatorname{la} \overline{1} \sim \rho^{\sim}\right)$ \\
\hline
\end{tabular}

Table 38: Gojri Verb Forms Marked for Aspect; Stem Ends in /e/: /le-/ 'take'

\begin{tabular}{|c|c|c|c|c|c|}
\hline & & Stem & Aspect & $\mathrm{AC}$ & Full form \\
\hline \multirow[t]{4}{*}{ Habitual (Negated) } & m.sg. & 1e- & $-\mathrm{t}$ & -0 & lets \\
\hline & m.pl. & 1e- & $-\mathrm{t}$ & $-\overline{\mathrm{a}}$ & letā \\
\hline & f.sg. & 1e- & $-\mathrm{t}$ & $-\overline{1}$ & let $\overline{1}$ \\
\hline & f.pl. & 1e- & $-\mathrm{t}$ & $-\overline{1} \sim(-\overline{1})$ & let $\overline{1} \sim(\operatorname{let} \overline{1})$ \\
\hline \multirow[t]{4}{*}{ Unspecified Perfective } & m.sg. & 1e- & -e $(-\overline{1})$ & -0 & līo \\
\hline & m.pl. & 1e- & $-\mathrm{e}(-\overline{1})$ & $-\overline{\mathrm{a}}$ & līà \\
\hline & f.sg. & 1e- & $-\mathrm{e}(-\overline{1})$ & $-\overline{1}$ & la $\overline{1}$ \\
\hline & f.pl. & 1e- & -e $(-\overline{1})$ & $-\overline{1} \sim(-\overline{1})$ & la $\overline{1} \sim($ la $\overline{1})$ \\
\hline
\end{tabular}


Table 39. Gojri Verb Forms Unmarked for Aspect; Stem Ends in /o/: /kho-/ 'pick'

\begin{tabular}{|c|c|c|c|c|c|}
\hline & & Stem & (Tense) & $\mathrm{PC}$ & Full form \\
\hline \multirow[t]{5}{*}{ Unspecified Habitual } & 1 sg. & kho- & & $-\overline{\mathrm{u}} \sim$ & khoū \\
\hline & $1 \mathrm{pl}$. & kho- & & $-\overline{\mathrm{a}} \sim$ & khoā $\sim$ \\
\hline & $2 / 3$ sg. & kho- & & $-\varepsilon$ & khoe \\
\hline & $2 \mathrm{pl}$. & kho- & & $-0(-\varepsilon)$ & khoo (khor) \\
\hline & 3 pl. & kho- & & $-\varepsilon^{\sim}(-\varepsilon)$ & khoe (khoe) \\
\hline \multirow[t]{5}{*}{ Negated Future } & $1 \mathrm{sg}$. & kho- & $-s$ & $-\overline{\mathrm{u}} \sim$ & khos̄̄ $\sim$ \\
\hline & $1 \mathrm{pl}$. & kho- & $-\mathrm{s}$ & $-\overline{\mathrm{a}} \sim$ & khosā̃ \\
\hline & $2 / 3$ sg. & kho- & $-\mathrm{s}$ & $-\varepsilon$ & khose \\
\hline & $2 \mathrm{pl}$. & kho- & $-\mathrm{s}$ & $-0(-\varepsilon)$ & khoso (khose) \\
\hline & 3 pl. & kho- & $-\mathrm{s}$ & $-\varepsilon^{\sim}(-\varepsilon)$ & khose $\sim$ (khose) \\
\hline \multirow[t]{2}{*}{ Present Imperative } & 2 sg. & kho- & & $\emptyset$ & kho \\
\hline & 2 pl. & kho- & & $-0\left(-0^{\sim}\right)$ & khos $\left(\mathrm{kho}^{\sim}\right)$ \\
\hline \multirow[t]{2}{*}{ Future Imperative } & 2 sg. & kho- & $-\overline{1}(-\overline{1} \sim)$ & $-\mathrm{e}$ & khoīe (khōi $\sim$ e) \\
\hline & $2 \mathrm{pl}$. & kho- & $-\overline{1}(-\overline{1} \sim)$ & $-0\left(-0^{\sim}\right)$ & khō̄o (khō̄̄ $\left.\sim \rho^{\sim}\right)$ \\
\hline
\end{tabular}

Table 40. Gojri Verb Forms Marked for Aspect: Stem Ends in /o/: /kho-/ 'pick'

\begin{tabular}{|c|c|c|c|c|c|}
\hline & & Stem & Aspect & $\mathrm{AC}$ & Full form \\
\hline \multirow[t]{4}{*}{ Habitual (Negated) } & m.sg. & kho- & $-\mathrm{t}$ & -0 & khoto \\
\hline & m.pl. & kho- & $-\mathrm{t}$ & $-\overline{\mathrm{a}}$ & khotā \\
\hline & f.sg. & kho- & $-\mathrm{t}$ & $-\overline{1}$ & khotī \\
\hline & f.pl. & kho- & $-\mathrm{t}$ & $-\overline{1} \sim(-\overline{1})$ & $\operatorname{khot} \overline{1} \sim(\operatorname{khot} \overline{1})$ \\
\hline \multirow[t]{4}{*}{ Unspecified Perfective } & m.sg. & kho- & -e $(-\overline{1})$ & -0 & khoes \\
\hline & m.pl. & kho- & -e $(-\overline{1})$ & $-\overline{\mathrm{a}}$ & khoeā \\
\hline & f.sg. & kho- & -e $(-\overline{1})$ & $-\overline{1}$ & khōi \\
\hline & f.pl. & kho- & -e $(-\overline{1})$ & $-\overline{1} \sim(-\overline{1})$ & khōī (khōi) \\
\hline
\end{tabular}

The inflections shown for /kho-/ in tables 39 and 40 are identical to those for /ro-/ 
'cry' and /so-/ 'sleep', except where they show irregular perfects; for example, /rūṇī/ 'she cried', /suttīi 'she slept'.

Table 41. Gojri Verb Forms Unmarked for Aspect; Stem Ends in /ó/: /kó/ 'slaughter'

\begin{tabular}{|c|c|c|c|c|c|}
\hline & & Stem & (Tense) & $\mathrm{PC}$ & Full form \\
\hline \multirow[t]{5}{*}{ Unspecified Habitual } & $1 \mathrm{sg}$. & kó- & & $-\overline{\mathrm{u}} \sim$ & kóū $\sim$ \\
\hline & $1 \mathrm{pl}$. & kó- & & $-\overline{\mathrm{a}} \sim$ & kóā \\
\hline & $2 / 3$ sg. & kó- & & $-\varepsilon$ & kóe \\
\hline & $2 \mathrm{pl}$ & kó- & & $-0(-\varepsilon)$ & kóo (kóe) \\
\hline & $3 \mathrm{pl}$. & kó- & & $-\varepsilon^{\sim}(-\varepsilon)$ & kóe (kóe) \\
\hline \multirow[t]{5}{*}{ Negated Future } & 1 sg. & kó- & $-S$ & $-\overline{\mathrm{u}}^{\sim}$ & kósū $\sim$ \\
\hline & $1 \mathrm{pl}$. & kó- & $-\mathrm{s}$ & $-\overline{\mathrm{a}}^{\sim}$ & kósā $\sim$ \\
\hline & $2 / 3$ sg. & kó- & $-\mathrm{S}$ & $-\varepsilon$ & kóse \\
\hline & $2 \mathrm{pl}$. & kó- & $-\mathrm{s}$ & $-0(-\varepsilon)$ & kóso (kóse) \\
\hline & 3 pl. & kó- & $-\mathrm{S}$ & $-\varepsilon^{\sim}(-\varepsilon)$ & kóse (kóse) \\
\hline \multirow[t]{2}{*}{ Present Imperative } & 2 sg. & kó- & & $\emptyset$ & kó \\
\hline & $2 \mathrm{pl}$. & kó- & & $-\supset\left(-\rho^{\sim}\right)$ & kóo (kó ) \\
\hline \multirow[t]{2}{*}{ Future Imperative } & $2 \mathrm{sg}$. & kó- & $-\overline{1}(-\overline{1} \sim)$ & $-\mathrm{e}$ & kóie (kóīe) \\
\hline & $2 \mathrm{pl}$ & kó- & $-\overline{1}(-\overline{1} \sim)$ & $-0\left(-0^{\sim}\right)$ & kóīo (kóī య ) \\
\hline
\end{tabular}

Table 42. Gojri Verb Forms Marked for Aspect; Stem Ends in /ó/: /kó-/ 'slaughter'

\begin{tabular}{|c|c|c|c|c|c|}
\hline & & Stem & Aspect & $\mathrm{AC}$ & Full form \\
\hline \multirow[t]{4}{*}{ Habitual (Negated) } & m.sg. & kó- & $-\mathrm{t}$ & -0 & kóto \\
\hline & m.pl. & kó- & $-\mathrm{t}$ & $-\overline{\mathrm{a}}$ & kótā \\
\hline & f.sg. & kó- & $-\mathrm{t}$ & $-\overline{1}$ & kótī \\
\hline & f.pl. & kó- & $-\mathrm{t}$ & $-\overline{1} \sim(-\overline{1})$ & kótī $\sim(k o ́ t \overline{1})$ \\
\hline \multirow[t]{4}{*}{ Unspecified Perfective } & m.sg. & kó- & $-\mathrm{e}(-\overline{1})$ & -0 & kóes \\
\hline & m.pl. & kó- & $-\mathrm{e}(-\overline{1})$ & $-\overline{\mathrm{a}}$ & kóeā \\
\hline & f.sg. & kó- & $-\mathrm{e}(-\overline{1})$ & $-\overline{1}$ & kóī \\
\hline & f.pl. & kó- & $-\mathrm{e}(-\overline{1})$ & $-\overline{1} \sim(-\overline{1})$ & kóī (kóī) \\
\hline
\end{tabular}




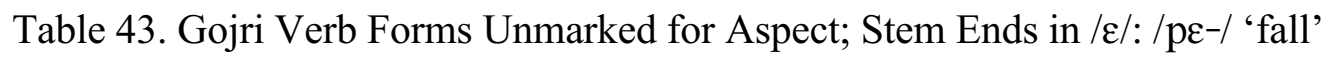

\begin{tabular}{|c|c|c|c|c|c|}
\hline & & Stem & (Tense) & $\mathrm{PC}$ & Full form \\
\hline \multirow[t]{5}{*}{ Unspecified Habitual } & 1sg. & $\mathrm{p} \varepsilon^{-}$ & & $-\overline{\mathrm{u}} \sim$ & --- \\
\hline & $1 \mathrm{pl}$ & $\mathrm{p} \varepsilon^{-}$ & & $-\overline{\mathrm{a}} \sim$ & --- \\
\hline & $2 / 3 \mathrm{sg}$ & $\mathrm{p} \varepsilon^{-}$ & & $-\varepsilon$ & pos (pe) \\
\hline & $2 \mathrm{pl}$ & $\mathrm{p} \varepsilon^{-}$ & & $-\supset(-\varepsilon)$ & --- \\
\hline & $3 \mathrm{pl}$ & $\mathrm{p} \varepsilon^{-}$ & & $-\varepsilon^{\sim}(-\varepsilon)$ & pos $(\mathrm{p} \varepsilon)$ \\
\hline \multirow[t]{5}{*}{ Negated Future } & $1 \mathrm{sg}$. & $\mathrm{p} \varepsilon^{-}$ & $-S$ & $-\overline{\mathrm{u}} \sim$ & --- \\
\hline & $1 \mathrm{pl}$. & $\mathrm{p} \varepsilon^{-}$ & $-S$ & $-\overline{\mathbf{a}} \sim$ & --- \\
\hline & $2 / 3$ sg. & $\mathrm{p} \varepsilon^{-}$ & $-S$ & $-\mathrm{e}$ & pese \\
\hline & $2 \mathrm{pl}$ & $\mathrm{p} \varepsilon^{-}$ & $-S$ & $-\supset(-\varepsilon)$ & --- \\
\hline & $3 \mathrm{pl}$ & $\mathrm{p} \varepsilon^{-}$ & $-S$ & $-\varepsilon^{\sim}(-\varepsilon)$ & $\mathrm{p} \varepsilon \mathrm{s} \varepsilon^{\sim}(\mathrm{p} \varepsilon \mathrm{s} \varepsilon)$ \\
\hline \multirow[t]{2}{*}{ Present Imperative } & $2 \mathrm{sg}$. & $p \varepsilon^{-}$ & & $\emptyset$ & --- \\
\hline & $2 \mathrm{pl}$. & $p \varepsilon^{-}$ & & $-\supset\left(-\rho^{\sim}\right)$ & --- \\
\hline \multirow[t]{2}{*}{ Future Imperative } & $2 \mathrm{sg}$. & $p \varepsilon^{-}$ & $-\overline{1} \quad(-\overline{1} \sim)$ & $-\mathrm{e}$ & --- \\
\hline & $2 \mathrm{pl}$. & $\mathrm{p} \varepsilon^{-}$ & $-\overline{1} \quad\left(-\overline{1}^{\sim}\right)$ & $-0\left(-0^{\sim}\right)$ & --- \\
\hline
\end{tabular}

The Eastern Unspecified Habitual forms shown in Table 43 are identical to those for /po-/ 'bead.'

Table 44. Gojri Verb Forms Marked for Aspect; Stem Ends in /e/: /pe-/ 'fall'

\begin{tabular}{|c|c|c|c|c|c|}
\hline & & Stem & Aspect & $\mathrm{AC}$ & Full form \\
\hline \multirow[t]{4}{*}{ Habitual (Negated) } & m.sg. & $\mathrm{p} \varepsilon^{-}$ & $-\mathrm{t}$ & -0 & peto \\
\hline & m.pl. & $\mathrm{p} \varepsilon^{-}$ & $-\mathrm{t}$ & $-\overline{\mathrm{a}}$ & petā \\
\hline & f.sg. & $\mathrm{p} \varepsilon^{-}$ & $-\mathrm{t}$ & $-\overline{1}$ & pet $\overline{1}$ \\
\hline & f.pl. & $\mathrm{p} \varepsilon^{-}$ & $-\mathrm{t}$ & $-\overline{1} \sim(-\overline{1})$ & $p \varepsilon t \overline{1} \sim(p \varepsilon t \overline{1})$ \\
\hline \multirow[t]{4}{*}{ Unspecified Perfective } & m.sg. & $\mathrm{p} \varepsilon^{-}$ & -e $(-\overline{1})$ & -0 & peo (pīo) \\
\hline & m.pl. & $\mathrm{p} \varepsilon^{-}$ & -e $(-\overline{1})$ & $-\overline{\mathrm{a}}$ & peā $(p \bar{i} \bar{a})$ \\
\hline & f.sg. & $\mathrm{p} \varepsilon^{-}$ & -e $(-\overline{1})$ & $-\overline{1}$ & páī \\
\hline & f.pl. & $\mathrm{p} \varepsilon^{-}$ & -e $(-\overline{1})$ & $-\overline{1} \sim(-\overline{1})$ & páī (páī) \\
\hline
\end{tabular}


The Western masculine perfects shown in Table 44 are identical to those for /p $\overline{1}-/$ 'drink.'

Table 45. Gojri Verb Forms Unmarked for Aspect; Stem Ends in /ع́/: /ré-/ 'stay’

\begin{tabular}{|c|c|c|c|c|c|}
\hline & & Stem & (Tense) & $\mathrm{PC}$ & Full form \\
\hline \multirow[t]{5}{*}{ Unspecified Habitual } & 1 sg. & ré- & & $-\overline{\mathrm{u}} \sim$ & ráū \\
\hline & $1 \mathrm{pl}$. & ré- & & $-\overline{\mathrm{a}} \sim$ & ráa \\
\hline & $2 / 3 \mathrm{sg}$. & ré- & & $-\varepsilon$ & ré \\
\hline & $2 \mathrm{pl}$. & ré- & & $-\supset(-\varepsilon)$ & ró (ré) \\
\hline & 3pl. & ré- & & $-\varepsilon^{\sim}(-\varepsilon)$ & 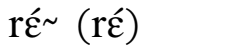 \\
\hline \multirow[t]{5}{*}{ Negated Future } & $1 \mathrm{sg}$. & ré- & $-\mathrm{s}$ & $-\overline{\mathrm{u}} \sim$ & résū \\
\hline & $1 \mathrm{pl}$. & ré- & $-\mathrm{s}$ & $-\overline{\mathrm{a}} \sim$ & résā̃ \\
\hline & 2/3sg. & ré- & $-\mathrm{s}$ & $-\varepsilon$ & rése \\
\hline & 2pl. & ré- & $-\mathrm{s}$ & $-0(-\varepsilon)$ & réso (rése) \\
\hline & 3pl. & ré- & $-\mathrm{s}$ & $-\varepsilon^{\sim}(-\varepsilon)$ & rése $\varepsilon^{\sim}(\mathrm{r} \varepsilon ́ s \varepsilon)$ \\
\hline \multirow[t]{2}{*}{ Present Imperative } & 2 sg. & ró- & & $\emptyset$ & ró \\
\hline & $2 \mathrm{pl}$. & ré- & & $-0\left(-\Omega^{\sim}\right)$ & ró (ró ) \\
\hline \multirow[t]{2}{*}{ Future Imperative } & 2 ssg. & ré- & $-\overline{1}(-\overline{1} \sim)$ & $-\mathrm{e}$ & ráīe (réī e) \\
\hline & 2pl. & ré- & $-\overline{1}(-\overline{1} \sim)$ & $-0\left(-0^{\sim}\right)$ & rá1̄o (réī $\left.\rho^{\sim}\right)$ \\
\hline
\end{tabular}

Table 46. Gojri Verb Forms Marked for Aspect; Stem Ends in /ع́/: /ré-/ 'stay'

\begin{tabular}{|c|c|c|c|c|c|}
\hline & & Stem & Aspect & $\mathrm{AC}$ & Full form \\
\hline \multirow[t]{4}{*}{ Habitual (Negated) } & m.sg. & ré- & $-\mathrm{t}$ & -0 & réto \\
\hline & m.pl. & ré- & $-\mathrm{t}$ & $-\overline{\mathrm{a}}$ & rétā \\
\hline & f.sg. & ré- & $-\mathrm{t}$ & $-\overline{1}$ & rétī \\
\hline & f.pl. & ré- & $-\mathrm{t}$ & $-\overline{1} \sim(-\overline{1})$ & rét $\overline{1} \sim$ (rétīi) \\
\hline \multirow[t]{4}{*}{ Unspecified Perfective } & m.sg. & ré- & -e $(-\overline{1})$ & -0 & réo (rí́o) \\
\hline & m.pl. & ré- & $-\mathrm{e}(-\overline{1})$ & $-\overline{\mathrm{a}}$ & 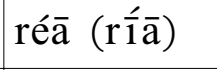 \\
\hline & f.sg. & ré- & $-\mathrm{e}(-\overline{1})$ & $-\overline{1}$ & rá 1 \\
\hline & f.pl. & ré- & -e $(-\overline{1})$ & $-\overline{1} \sim(-\overline{1})$ & ráī (ráī) \\
\hline
\end{tabular}




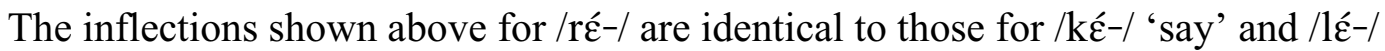
'get down' except where the latter shows irregular perfects, e.g. /lattho/ '(he) got down.'

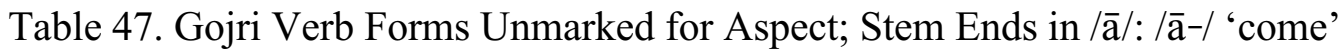

\begin{tabular}{|c|c|c|c|c|c|}
\hline & & Stem & (Tense) & $\mathrm{PC}$ & Full form \\
\hline \multirow[t]{5}{*}{ Unspecified Habitual } & $1 \mathrm{sg}$. & $\overline{\mathrm{a}}^{-}$ & & $-\overline{\mathrm{u}} \sim$ & $\overline{\mathrm{a}} \overline{\mathrm{u}} \sim \sim$ \\
\hline & $1 \mathrm{pl}$. & $\overline{\mathrm{a}}-$ & & $-\overline{\mathrm{a}} \sim$ & $\overline{\mathrm{a}} w \overline{\mathrm{a}}^{\sim}$ \\
\hline & $2 / 3$ sg. & $\overline{\mathrm{a}}-$ & & $-\varepsilon$ & $\bar{a} w \varepsilon(\bar{a} \varepsilon)$ \\
\hline & $2 \mathrm{pl}$. & $\overline{\mathrm{a}}-$ & & $-0(-\varepsilon)$ & $\overline{\mathrm{a}} \mathrm{w}$ (āe) \\
\hline & 3 pl. & $\overline{\mathrm{a}}-$ & & $-\varepsilon^{\sim}(-\varepsilon)$ & $\bar{a} w \varepsilon^{\sim}(\bar{a} \varepsilon)$ \\
\hline \multirow[t]{5}{*}{ Negated Future } & 1 sg. & $\overline{\mathrm{a}}-$ & $-\mathrm{s}$ & $-\bar{u}^{\sim}$ & $\overline{\mathrm{a} s} \overline{\mathrm{u}} \sim$ \\
\hline & $1 \mathrm{pl}$. & $\overline{\mathrm{a}}-$ & $-\mathrm{s}$ & $-\overline{\mathrm{a}} \sim$ & $\overline{\mathrm{a}} \mathrm{s} \overline{\mathrm{a}} \sim$ \\
\hline & $2 / 3$ sg. & $\overline{\mathrm{a}}-$ & $-\mathrm{s}$ & $-\varepsilon$ & $\bar{a} \mathbf{s} \varepsilon$ \\
\hline & $2 \mathrm{pl}$ & $\overline{\mathrm{a}}-$ & $-\mathrm{S}$ & $-\supset(-\varepsilon)$ & āso (āse) \\
\hline & $3 \mathrm{pl}$ & $\overline{\mathrm{a}}-$ & $-\mathrm{s}$ & $-\varepsilon^{\sim}(-\varepsilon)$ & $\overline{\mathrm{a}} \mathrm{s} \varepsilon^{\sim}(\overline{\mathrm{a}} \mathrm{s} \varepsilon)$ \\
\hline \multirow[t]{2}{*}{ Present Imperative } & 2 sg. & $\overline{\mathrm{a}}-$ & & $\emptyset$ & $\overline{\mathrm{a}}$ \\
\hline & $2 \mathrm{pl}$ & $\overline{\mathrm{a}}-$ & & $-\supset\left(-\jmath^{\sim}\right)$ & $\overline{\mathrm{a}} \mathrm{w}$ (ā⿰冫 $)$ \\
\hline \multirow[t]{2}{*}{ Future Imperative } & 2 sg. & $\overline{\mathrm{a}}-$ & $-\overline{1}\left(-\overline{1}^{\sim}\right)$ & $-\mathrm{e}$ & $\overline{\mathrm{a}} \overline{1} \mathrm{e}(\overline{\mathrm{a}} \overline{1} \sim \mathrm{e})$ \\
\hline & $2 \mathrm{pl}$ & $\overline{\mathrm{a}}-$ & $-\overline{1}(-\overline{1} \sim)$ & $-\supset\left(-\jmath^{\sim}\right)$ & $\overline{\mathrm{a}} \overline{1} \supset\left(\overline{\mathrm{a}} \overline{1} \sim \rho^{\sim}\right)$ \\
\hline
\end{tabular}

Table 48. Gojri Verb Forms Marked for Aspect; Stem Ends in /ā/: /ā-/ 'come'

\begin{tabular}{|c|c|c|c|c|c|}
\hline & & Stem & Aspect & $\mathrm{AC}$ & Full form \\
\hline \multirow[t]{4}{*}{ Habitual (Negated) } & m.sg. & $\overline{\mathrm{a}}-$ & $-\mathrm{t}$ & -0 & àto \\
\hline & m.pl. & $\overline{\mathrm{a}}-$ & $-\mathrm{t}$ & $-\overline{\mathrm{a}}$ & $\bar{a} t \bar{t}$ \\
\hline & f.sg. & $\overline{\mathrm{a}}-$ & $-\mathrm{t}$ & $-\overline{1}$ & $\overline{\mathrm{a}} \mathrm{t} \overline{\mathrm{i}}$ \\
\hline & f.pl. & $\overline{\mathrm{a}}-$ & $-\mathrm{t}$ & $-\overline{1} \sim(-\overline{1})$ & $\bar{a} t \overline{1} \sim(\bar{a} t \overline{1})$ \\
\hline \multirow[t]{4}{*}{ Unspecified Perfective } & m.sg. & $\overline{\mathrm{a}}-$ & -e $(-\overline{1})$ & -0 & $\bar{a} e s$ \\
\hline & m.pl. & $\overline{\mathrm{a}}-$ & $-\mathrm{e}(-\overline{1})$ & $-\overline{\mathrm{a}}$ & $\bar{a} \mathrm{e} \overline{\mathrm{a}}$ \\
\hline & f.sg. & $\overline{\mathrm{a}}-$ & $-\mathrm{e}(-\overline{1})$ & $-\overline{1}$ & $\overline{\mathrm{a}} \overline{\mathrm{1}}$ \\
\hline & f.pl. & $\overline{\mathrm{a}}-$ & -e $(-\overline{1})$ & $-\overline{1} \sim(-\overline{1})$ & $\overline{\mathrm{a}} \overline{1} \sim(\overline{\mathrm{a}} \overline{1})$ \\
\hline
\end{tabular}


The inflections shown for $/ \overline{\mathbf{a}}-/$ in tables 47 and 48 are identical to those for /čā-/ 'lift' and the defective verb /jā-/ 'go' (which is never a main verb in my data).

Table 49. Gojri Verb Forms Unmarked for Aspect; Stem Ends in /âa/: /lá-/ 'take off'

\begin{tabular}{|c|c|c|c|c|c|}
\hline & & Stem & (Tense) & $\mathrm{PC}$ & Full form \\
\hline \multirow[t]{5}{*}{ Unspecified Habitual } & 1 sg. & lá- & & $-\overline{\mathrm{u}} \sim$ & lấū \\
\hline & $1 \mathrm{pl}$. & lá́- & & $-\overline{\mathrm{a}} \sim$ & lấwā \\
\hline & $2 / 3$ sg. & lá́- & & $-\varepsilon$ & lấwe \\
\hline & $2 \mathrm{pl}$ & lá- & & $-0(-\varepsilon)$ & lấwo (lấc) \\
\hline & $3 \mathrm{pl}$. & lá́- & & $-\varepsilon^{\sim}(-\varepsilon)$ & lấwe (lấc) \\
\hline \multirow[t]{5}{*}{ Negated Future } & 1 sg. & lá- & $-\mathrm{s}$ & $-\overline{\mathrm{u}} \sim$ & lấsū $\sim$ \\
\hline & $1 \mathrm{pl}$. & lá- & $-s$ & $-\overline{\mathrm{a}}^{\sim}$ & lấsā̃ \\
\hline & $2 / 3$ sg. & lá́- & $-S$ & $-\varepsilon$ & lấse \\
\hline & $2 \mathrm{pl}$. & lá- & $-\mathrm{S}$ & $-0(-\varepsilon)$ & lấso (lấsc) \\
\hline & $3 \mathrm{pl}$. & lá- & $-\mathrm{S}$ & $-\varepsilon^{\sim}(-\varepsilon)$ & lấsq (lấse) \\
\hline \multirow[t]{2}{*}{ Present Imperative } & 2 sg. & lá- & & $\emptyset$ & lá \\
\hline & $2 \mathrm{pl}$. & lá́- & & $-0\left(-\Omega^{\sim}\right)$ & lấwo (lấ $\left.{ }^{\sim}\right)$ \\
\hline \multirow[t]{2}{*}{ Future Imperative } & 2 sg. & lá- & $-\overline{1}(-\overline{1} \sim)$ & $-e$ & láâe (lấī e) \\
\hline & $2 \mathrm{pl}$ & lá- & $-\overline{1}(-\overline{1} \sim)$ & $-0\left(-\Omega^{\sim}\right)$ & láīo (lấ̄ं $\left.0^{\sim}\right)$ \\
\hline
\end{tabular}

Table 50. Gojri Verb Forms Marked for Aspect; Stem Ends in /ấ/: /lấ-/ 'take off'

\begin{tabular}{|c|c|c|c|c|c|}
\hline & & Stem & Aspect & $\mathrm{AC}$ & Full form \\
\hline \multirow{4}{*}{ Habitual (Negated) } & m.sg. & lá- & $-t$ & -0 & lấto \\
\hline & m.pl. & lá- & $-\mathrm{t}$ & $-\overline{\mathrm{a}}$ & lấtā \\
\hline & f.sg. & lá́- & $-\mathrm{t}$ & $-\overline{1}$ & lấtī \\
\hline & f.pl. & lá- & $-\mathrm{t}$ & $-\overline{1} \sim(-\overline{1})$ & lấtī (lất̄ī) \\
\hline \multirow[t]{4}{*}{ Unspecified Perfective } & m.sg. & lá- & -e $(-\overline{1})$ & -0 & láes \\
\hline & m.pl. & lá- & -e $(-\overline{1})$ & $-\overline{\mathrm{a}}$ & lấeā \\
\hline & f.sg. & lá- & -e $(-\overline{1})$ & $-\overline{1}$ & lấ1 \\
\hline & f.pl. & lá- & $-e(-\overline{1})$ & $-\overline{1} \sim(-\overline{1})$ & 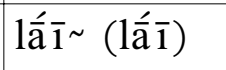 \\
\hline
\end{tabular}


Table 51. Gojri Verb Forms Unmarked for Aspect: /de-/ 'give'

\begin{tabular}{|c|c|c|c|c|c|}
\hline & & Stem & (Tense) & $\mathrm{PC}$ & Full form \\
\hline \multirow[t]{5}{*}{ Unspecified Habitual } & $1 \mathrm{sg}$. & de- & & $-\overline{\mathrm{u}} \sim$ & $\mathrm{d} \overline{1} \overline{\mathrm{u}} \sim$ \\
\hline & $1 \mathrm{pl}$. & de- & & $-\overline{\mathrm{a}} \sim$ & deā $\sim(d \overline{1} \bar{a} \sim)$ \\
\hline & $2 / 3$ sg. & de- & & $-\varepsilon$ & $\operatorname{de} \varepsilon(\mathrm{d} \overline{1} \varepsilon)$ \\
\hline & $2 \mathrm{pl}$. & de- & & $-0(-\varepsilon)$ & déo $(\mathrm{d} \overline{1} \varepsilon)$ \\
\hline & 3pl. & de- & & $-\varepsilon^{\sim}(-\varepsilon)$ & dé (dīe) \\
\hline \multirow[t]{5}{*}{ Negated Future } & 1 sg. & de- & $-S$ & $-\overline{\mathrm{u}} \sim$ & $\operatorname{des} \bar{u}^{\sim}$ \\
\hline & $1 \mathrm{pl}$. & de- & $-\mathrm{s}$ & $-\overline{\mathrm{a}}^{\sim}$ & $\operatorname{des} \bar{a}^{\sim}$ \\
\hline & $2 / 3$ sg. & de- & $-\mathrm{s}$ & $-\mathrm{e}$ & $\operatorname{des} \varepsilon$ \\
\hline & $2 \mathrm{pl}$. & de- & $-\mathrm{s}$ & $-0(-\varepsilon)$ & deso (dese) \\
\hline & 3 pl. & de- & $-\mathrm{s}$ & $-\varepsilon^{\sim}(-\varepsilon)$ & $\operatorname{des} \varepsilon^{\sim}(\operatorname{des} \varepsilon)$ \\
\hline \multirow[t]{2}{*}{ Present Imperative } & 2 sg. & de- & & $\emptyset$ & dé \\
\hline & $2 \mathrm{pl}$. & de- & & $-0\left(-0^{\sim}\right)$ & déo $\left(\mathrm{d} \overline{1} \jmath^{\sim}\right)$ \\
\hline \multirow[t]{2}{*}{ Future Imperative } & 2 sg. & de- & $-\overline{1}(-\overline{1} \sim)$ & $-\varepsilon$ & dáīe (dáī e) \\
\hline & $2 \mathrm{pl}$. & de- & $-\overline{1}\left(-\overline{1}^{\sim}\right)$ & $-0\left(-0^{\sim}\right)$ & dá $1 ̄$ (dá $\left.\overline{1} \sim 0^{\sim}\right)$ \\
\hline
\end{tabular}

All high tone markings shown in Table 51 are tentative. High tone cannot be lexical for this verb since it never occurs in the bare-stem conjunctive participle (see 5.3.1). Table 52. Gojri Verb Forms Marked for Aspect: /de-/ 'give'

\begin{tabular}{|c|c|c|c|c|c|}
\hline & & Stem & Aspect & $\mathrm{AC}$ & Full form \\
\hline \multirow[t]{4}{*}{ Habitual (Negated) } & m.sg. & $\mathrm{de}^{-}$ & $-\mathrm{t}$ & -0 & deto \\
\hline & m.pl. & de- & $-\mathrm{t}$ & $-\overline{\mathrm{a}}$ & $\operatorname{detā}$ \\
\hline & f.sg. & de- & $-\mathrm{t}$ & $-\overline{1}$ & $\operatorname{det} \overline{1}$ \\
\hline & f.pl. & de- & $-\mathrm{t}$ & $-\overline{1} \sim(-\overline{1})$ & $\operatorname{det} \overline{1} \sim(\operatorname{det} \overline{1})$ \\
\hline \multirow[t]{4}{*}{ Unspecified Perfective } & m.sg. & de- & -e $(-\overline{1})$ & -0 & ditto (dītto) \\
\hline & m.pl. & de- & -e $(-\overline{1})$ & $-\bar{a}$ & $\operatorname{dittā}(\mathrm{d} \overline{1} \mathrm{tta})$ \\
\hline & f.sg. & de- & $-\mathrm{e}(-\overline{1})$ & $-\overline{1}$ & $\operatorname{ditt} \overline{1}$ \\
\hline & f.pl. & de- & -e $(-\overline{1})$ & $-\overline{1} \sim(-\overline{1})$ & $\operatorname{ditt} \overline{1} \sim(\operatorname{ditt} \overline{1})$ \\
\hline
\end{tabular}


Table 53. Gojri Verb Forms Unmarked for Aspect: /hò-/ 'be'

\begin{tabular}{|c|c|c|c|c|c|}
\hline & & Stem & (Tense) & $\mathrm{PC}$ & Full form \\
\hline \multirow[t]{5}{*}{ Unspecified Habitual } & $1 \mathrm{sg}$. & hò- & & $-\overline{\mathrm{u}} \sim$ & hòū \\
\hline & $1 \mathrm{pl}$. & hò- & & $-\overline{\mathrm{a}} \sim$ & hòwā (wà̄ ) \\
\hline & $2 / 3 \mathrm{sg}$ & hò- & & $-\varepsilon$ & hòwe (wè) \\
\hline & $2 \mathrm{pl}$ & hò- & & $-0(-\varepsilon)$ & hòwว (wè) \\
\hline & $3 \mathrm{pl}$ & hò- & & $-\varepsilon^{\sim}(-\varepsilon)$ & hòwe (wè) \\
\hline \multirow[t]{5}{*}{ Negated Future } & $1 \mathrm{sg}$. & hò- & $-\mathrm{S}$ & $-\overline{\mathrm{u}} \sim$ & hòsū $\sim$ \\
\hline & $1 \mathrm{pl}$. & hò- & $-\mathrm{s}$ & $-\bar{a} \sim$ & hòsā \\
\hline & $2 / 3 \mathrm{sg}$ & hò- & $-S$ & $-\varepsilon$ & hòse \\
\hline & $2 \mathrm{pl}$ & hò- & $-S$ & $-0(-\varepsilon)$ & hòso (hòse) \\
\hline & $3 \mathrm{pl}$ & hò- & $-\mathrm{S}$ & $-\varepsilon^{\sim}(-\varepsilon)$ & hòse (hòse) \\
\hline \multirow[t]{2}{*}{ Present Imperative } & $2 \mathrm{sg}$ & hò- & & $\emptyset$ & hò \\
\hline & $2 \mathrm{pl}$ & hò- & & $-0\left(-0^{\sim}\right)$ & hòws (hò w) \\
\hline \multirow[t]{2}{*}{ Future Imperative } & $2 \mathrm{sg}$. & hò- & $-\overline{1}(-\overline{1} \sim)$ & $-\mathrm{e}$ & hò̀e (hò̀̄ e) \\
\hline & $2 \mathrm{pl}$ & hò- & $-\overline{1}\left(-\overline{1}^{\sim}\right)$ & $-0\left(-0^{\sim}\right)$ & hò̀̄o (hò̄̄ య ) \\
\hline
\end{tabular}

Table 54. Gojri Verb Forms Marked for Aspect: /hò-/ 'be'

\begin{tabular}{|c|c|c|c|c|c|}
\hline & & Stem & Aspect & $\mathrm{AC}$ & Full form \\
\hline \multirow[t]{4}{*}{ Habitual (Negated) } & m.sg. & hò- & $-\mathrm{t}$ & -0 & hòts \\
\hline & m.pl. & hò- & $-\mathrm{t}$ & $-\overline{\mathrm{a}}$ & hòtā \\
\hline & f.sg. & hò- & $-\mathrm{t}$ & $-\overline{1}$ & hòt $\overline{1}$ \\
\hline & f.pl. & hò- & $-\mathrm{t}$ & $-\overline{1} \sim(-\overline{1})$ & hòt $\overline{1} \sim$ (hòt $\overline{1})$ \\
\hline \multirow[t]{4}{*}{ Unspecified Perfective } & m.sg. & hò- & -e $(-\overline{1})$ & -0 & hòes / hūo \\
\hline & m.pl. & hò- & -e $(-\overline{1})$ & $-\overline{\mathrm{a}}$ & hòeā / hù̄ā \\
\hline & f.sg. & hò- & -e $(-\overline{1})$ & $-\overline{1}$ & hò̀ / hù̀ \\
\hline & f.pl. & hò- & -e $(-\overline{1})$ & $-\overline{1} \sim(-\overline{1})$ & hò̄ ( hò $\overline{1})$ \\
\hline
\end{tabular}


In Table 54, the right-most perfective variants which are not in parentheses occur only in Eastern speech varieties.

Table 55. Gojri Verb Forms Unmarked for Aspect: /kar/ 'do'

\begin{tabular}{|c|c|c|c|c|c|}
\hline & & Stem & (Tense) & PC & Full form \\
\hline \multirow[t]{5}{*}{ Unspecified Habitual } & 1 sg. & kar- & & $-\overline{\mathrm{u}} \sim$ & karū $\sim$ \\
\hline & $1 \mathrm{pl}$. & kar- & & $-\overline{\mathrm{a}}^{\sim}$ & karā $\sim$ \\
\hline & $2 / 3$ sg. & kar- & & $-\varepsilon$ & kare \\
\hline & $2 \mathrm{pl}$ & kar- & & $-\supset(-\varepsilon)$ & karo (kare) \\
\hline & 3 pl. & kar- & & $-\varepsilon^{\sim}(-\varepsilon)$ & $\operatorname{kar}^{\sim}(\operatorname{kar} \varepsilon)$ \\
\hline \multirow[t]{5}{*}{ Negated Future } & 1 sg. & kar- & $-s$ & $-\overline{\mathrm{u}} \sim$ & karsū $\sim$ \\
\hline & $1 \mathrm{pl}$. & kar- & $-s$ & $-\overline{\mathrm{a}}^{\sim}$ & karsā̃ \\
\hline & $2 / 3$ sg. & kar- & $-\mathrm{S}$ & $-\varepsilon$ & karse \\
\hline & $2 \mathrm{pl}$. & kar- & $-s$ & $-\supset(-\varepsilon)$ & karso (karse) \\
\hline & 3 pl. & kar- & $-\mathrm{S}$ & $-\varepsilon^{\sim}(-\varepsilon)$ & karse $\sim(\operatorname{kars} \varepsilon)$ \\
\hline \multirow[t]{2}{*}{ Present Imperative } & $2 \mathrm{sg}$. & kar- & & $\emptyset$ & kar \\
\hline & $2 \mathrm{pl}$. & kar- & & $-0\left(-\rho^{\sim}\right)$ & kars $\left.(\operatorname{kar})^{\sim}\right)$ \\
\hline \multirow[t]{2}{*}{ Future Imperative } & $2 \mathrm{sg}$. & kar- & $-\overline{1}(-\overline{1} \sim)$ & $-\mathrm{e}$ & $\operatorname{kar} \overline{1} \mathrm{e}(\operatorname{kar} \overline{1} \sim \mathrm{e})$ \\
\hline & $2 \mathrm{pl}$. & kar- & $-\overline{1}(-\overline{1} \sim)$ & $-0\left(-\rho^{\sim}\right)$ & $\operatorname{kar} \overline{1} \supset\left(\operatorname{kar} \overline{1} \sim 0^{\sim}\right)$ \\
\hline
\end{tabular}

Table 56. Gojri Verb Forms Marked for Aspect: /kar-/ 'do'

\begin{tabular}{|c|c|c|c|c|c|}
\hline & & Stem & Aspect & $\mathrm{AC}$ & Full form \\
\hline \multirow[t]{4}{*}{ Habitual (Negated) } & m.sg. & kar- & $-\mathrm{t}$ & -0 & karto \\
\hline & m.pl. & kar- & $-\mathrm{t}$ & $-\overline{\mathrm{a}}$ & kartā \\
\hline & f.sg. & kar- & $-\mathrm{t}$ & $-\overline{1}$ & $\operatorname{kart} \overline{1}$ \\
\hline & f.pl. & kar- & $-\mathrm{t}$ & $-\overline{1} \sim(-\overline{1})$ & $\operatorname{kart\overline {1}} \sim(\operatorname{kart} \overline{1})$ \\
\hline \multirow[t]{4}{*}{ Unspecified Perfective } & m.sg. & kar- & -e $(-\overline{1})$ & -0 & kares $(\operatorname{kar} \overline{1} \jmath) / \mathrm{k} \overline{1} \mathrm{\jmath}$ \\
\hline & m.pl. & kar- & $-\mathrm{e}(-\overline{1})$ & $-\overline{\mathrm{a}}$ & kareā $(\operatorname{kar} \overline{1} \bar{a}) / \mathrm{k} \overline{1} \bar{a}$ \\
\hline & f.sg. & kar- & $-\mathrm{e}(-\overline{1})$ & $-\overline{1}$ & $\operatorname{kar} \overline{1} / \mathrm{k} \overline{1}(\mathrm{ka} \overline{1})$ \\
\hline & f.pl. & kar- & -e $(-\overline{1})$ & $-\overline{1} \sim(-\overline{1})$ & $\operatorname{kar} \overline{1} \sim(\operatorname{kar} \overline{1}) / \mathrm{k} \overline{1} \sim(k \overline{1})(\operatorname{ka} \overline{1})$ \\
\hline
\end{tabular}


Table 57. Gojri Verb Forms Unmarked for Aspect: /čal-/ 'go'

\begin{tabular}{|c|c|c|c|c|c|}
\hline & & Stem & (Tense) & $\mathrm{PC}$ & Full form \\
\hline \multirow[t]{5}{*}{ Unspecified Habitual } & $1 \mathrm{sg}$. & čal- & & $-\overline{\mathrm{u}} \sim$ & čalū $\sim$ \\
\hline & $1 \mathrm{pl}$. & čal- & & $-\overline{\mathrm{a}}^{\sim}$ & čalā \\
\hline & $2 / 3$ sg. & čal- & & $-\varepsilon$ & čale \\
\hline & $2 \mathrm{pl}$. & čal- & & $-0(-\varepsilon)$ & čalo (čale) \\
\hline & $3 \mathrm{pl}$. & čal- & & $-\varepsilon^{\sim}(-\varepsilon)$ & čale (čale) \\
\hline \multirow[t]{5}{*}{ Negated Future } & 1 sg. & čal- & $-\mathrm{s}$ & $-\overline{\mathrm{u}} \sim$ & čalsū $\sim$ \\
\hline & $1 \mathrm{pl}$ & čal- & $-\mathrm{s}$ & $-\overline{\mathrm{a}} \sim$ & čalsā \\
\hline & $2 / 3$ sg. & čal- & $-\mathrm{s}$ & $-\varepsilon$ & čalse \\
\hline & $2 \mathrm{pl}$. & čal- & $-s$ & $-0(-\varepsilon)$ & čalso (čalse) \\
\hline & $3 \mathrm{pl}$. & čal- & $-\mathrm{s}$ & $-\varepsilon^{\sim}(-\varepsilon)$ & čalse $\sim$ (čalse) \\
\hline \multirow[t]{2}{*}{ Present Imperative } & 2 sg. & čal- & & $\emptyset$ & čal \\
\hline & $2 \mathrm{pl}$. & čal- & & $-0\left(-0^{\sim}\right)$ & čalo (čalo ) \\
\hline \multirow[t]{2}{*}{ Future Imperative } & $2 \mathrm{sg}$. & čal- & $-\overline{\mathbf{1}}(-\overline{\mathbf{1}} \sim)$ & $-\mathrm{e}$ & čalīe (čalī e) \\
\hline & $2 \mathrm{pl}$. & čal- & $-\overline{1}\left(-\overline{1}^{\sim}\right)$ & $-0\left(-0^{\sim}\right)$ & čalīo (čalī $\left.\rho^{\sim}\right)$ \\
\hline
\end{tabular}

Table 58. Gojri Verb Forms Marked for Aspect: /čal-/ 'go'

\begin{tabular}{|c|c|c|c|c|c|}
\hline & & Stem & Aspect & $\mathrm{AC}$ & Full form \\
\hline \multirow[t]{4}{*}{ Habitual (Negated) } & m.sg. & čal- & $-\mathrm{t}$ & -0 & čalto \\
\hline & m.pl. & čal- & $-\mathrm{t}$ & $-\bar{a}$ & čaltā \\
\hline & f.sg. & čal- & $-t$ & $-\overline{1}$ & čaltī \\
\hline & f.pl. & čal- & $-\mathrm{t}$ & $-\overline{1} \sim(-\overline{1})$ & čaltī $\sim(\check{c}$ calt $\overline{1})$ \\
\hline \multirow[t]{4}{*}{ Unspecified Perfective } & m.sg. & ------- & -e $(-\overline{1})$ & -0 & gīo (gīo) \\
\hline & m.pl. & ------- & -e $(-\overline{1})$ & $-\overline{\mathrm{a}}$ & $g \overline{1} \bar{a}$ \\
\hline & f.sg. & ------- & -e $(-\overline{1})$ & $-\overline{1}$ & ga $\overline{1}$ \\
\hline & f.pl. & ------ & -e $(-\overline{1})$ & $-\overline{\mathbf{1}}^{\sim}(-\overline{\mathbf{1}})$ & ga $\overline{1} \sim(\operatorname{ga} \overline{1})$ \\
\hline
\end{tabular}




\section{NOTES}

\section{Chapter 1}

1. The transliteration Gojri reflects the Eastern pronunciation/gojarīi/of Gujar language developers (and so Sharma 1979, 1982) while Gujari reflects the Western pronunciation /gujarīi/ (so Grierson 1973 (c1903); most other writers).

2. For example, compare the discussion and references in Hallberg and O'Leary (1992:9496) to Khatana's conclusions (1992:52-53).

3. My source for this information and Gojri data from the Muzaffarabad area is Professor Sabir Afaqi, Ph.D, whom I interviewed in Abbottabad December 13-15, 2000.

4. Weber (1994) reviews the relevant literature while building a strong case for a Hispanic (Spanish-based) orthography for Quechua. The quotes by Walker and D'Emilio in this section are taken from pages 97 and 96 of the English version of his book, respectively.

5. That the major division within the nomadic Bakarwal community might correlate with a linguistic division that mirrors the East-West dialect division among settled Gujars is a hypothesis suggested when a passage in Kathana is read in light of the sociolinguistic survey conclusions:

... the Gujjar Bakarwals distinguish themselves also as Kunhari Gujjar Bakarwals and Illahiwal Gujjar Bakarwals. They derive these epithets from the name of the areas to which their ancestors belonged before they migrated to the State of Jammu and Kashmir. The Kunhari Gujjar Bakarwals claim that their ancestors came from the valley of Kunhar. The Kunhar valley lies in the region of Kagan (Pakistan) consisting of the tributaries of the Kunhar, the Bogarmang, the Konash, and the Saran river valleys ... The Illahiwal Gujjar Bakarwals claim that their ancestors came from the region of Illahiwal, consisting of the tributaries of the Nandhar, the Rajawari, the 
Kaladhaka, the Kohistan and the Swat (Pakistan) valleys (1992:52; italics and spellings his).

The linguistic evidence supporting this hypothesis includes the fact that the historic voiced aspirates (see 3.1.2.4) remain voiced in the Allaiwal Bakarwal subdialect, the Allaiwal Bakarwal Muhajar subdialect, and in the Western varieties reported in Hallberg and O'Leary (1992); while these segments are voiceless in the Kaghani Bakarwal subdialect, the Kunhari Bakarwal Muhajar subdialect, and in the Eastern varieties reported in Hallberg and O'Leary. See the lexical data given in Appendix B for word numbers $12,35,37,48,56,59,107-108,112,117,132,144$, and 179 . Words 51 and 103 provide further evidence, albeit by means of partial data sets.

6. In November 2000, this assistant administered a written morphological questionnaire (eliciting translations of select Eastern sentences) to twelve Gujar men in various parts of Swat, the results of which, together with Grierson's data, confirm that Allaiwal morphology is indeed representative of the broader Western dialect.

\section{Chapter 2}

1. Interestingly, however, some Gojri words containing /o/ like /póč/ 'arrive!' have an /a/ + /u/ Urdu cognate, i.e. /pahunč/.

\section{$\underline{\text { Chapter } 3}$}

1. The labels 'low tone', 'high tone', and 'mid tone' are used at points in the present work, per usage by Sharma, Masica (r.e. Punjabi; 1991:118), and those he cites. These tones are marked in my phonemic transcriptions according to the orientalist transcription of Punjabi tone (Masica 1991:205). 
2. The analysis here is with reference to the concepts and apparatus of Autosegmental Phonology (for an introduction to this theory, see Goldsmith (1990) and Gussenhoven \& Jacobs (1998)).

3. One possible strategy for solving the ambiguities noted here would involve placing a vowel diacritic on choti he in the case of words with low-rising pitch, and on the consonant preceding choti he in the case of words with high-falling pitch. Even so, the result would be a tone orthography that does not work for the Western dialect, and one that deviates drastically from the 'iconic' orthography that most Eastern writers are actually using (further explored in 3.2.2.4).

4. This spelling is partially motivated by a desire for symmetry with تهارو /thà̀rs/pl. 'your'.

\section{Chapter 4}

1. I do not discuss the structure of relative clauses in this paper.

2. Compare (201) with the use of the present auxiliary /h-/ in (339) to indicate that a particular state of affairs holds at the time of speaking:

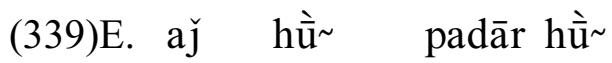

today $1 \mathrm{sg} . \mathrm{NOM}$ busy $1 \mathrm{sg}$. PRES

'Today I am busy.'

Compare (202) with the use of the past auxiliary /th-/ in (340) to indicate that a particular state of affairs held at some time prior to the time of speaking:

$$
\begin{aligned}
& \text { kal hì̀ } \quad \text { padār th-っ } \\
& \text { yesterday } 1 \text { 1sg.NOM busy } \text { PAST-NOM.M.SG } \\
& \text { 'Yesterday I was busy.' }
\end{aligned}
$$


3. As explained in 4.2.1.7, the $/ \mathrm{w}-/$ formative occurs with the perfective form of the verb (primarily in Eastern) to form perfective adjectival participles. For example, /(tamū)

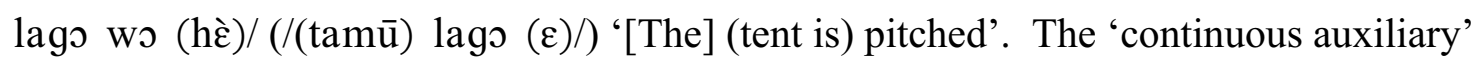
/lag-/, together with /w-/ in Eastern, therefore comprises a perfective adjectival participle modifying the subject. Originally, this participle probably denoted that the subject was 'engaged' or 'started' (to use English participles) with respect to the verbal action (cf. the inceptive use of /lag-/ in 4.2.2.3).

4. The meaning of /pe-/ 'fall' in this construction is stronger than that conveyed when the copula is used in the same construction, as the latter expresses the agent's internal compulsion to act. For example, consider the Eastern /minnā čalṇı hè/ 'I have to go.' 


\section{REFERENCES}

Adams, Marilyn Jager. 1990. Beginning to read: Thinking and learning about print. Cambridge, MA: MIT Press.

Afaqi, Sabir. 1976. Phul kheli. Muzaffarabad: Gojri Adabi Board.

Afaqi, Sabir. 1995. Aks-e-Kashmir. Lahore: Maqbool Academy.

Ahmed, Akbar S. 1986. Pakistan society: Islam, ethnicity and leadership in South Asia. Karachi: Oxford University Press.

Azim, Iqbal, et al. (eds). 1985. Gojri Dictionary. Srinagar: Jammu \& Kashmir Academy of Art, Culture \& Languages.

Baart, Joan L.G. 1999. A sketch of Kalam Kohistani grammar. Islamabad: National Institute of Pakistan Studies and Summer Institute of Linguistics. (Studies in languages of Northern Pakistan Vol. 5).

Bailey, Thomas Grahame. 1903. Studies in Northern Himalayan dialects. Calcutta: Baptist Mission Press.

Barth, Fredrik. 1956. Indus and Swat Kohistan: An ethnographic survey. Studies honouring the centennial of universitetets etnografiske museum, Oslo, 2. Oslo: Forende Trykkerier.

Bhat, D.N.S. 1999. The prominence of tense, aspect, and mood. Amsterdam: Benjamins.

Bhatia, Tej K. 1975. The evolution of tones in Punjabi. Studies in the Linguistic Sciences 5:2.12-24.

Bird, Steven. 1996. Principles of African tone orthography design. Research Paper 80, University of Edinburgh, Human Communication Research Centre. 
Bird, Steven. 1997. When marking tone reduces fluency: An orthography experiment in Cameroon. Research Paper 91, University of Edinburgh, Human Communication Research Centre, 1997.

Ehri, L.C., and L.S. Wilce. 1986. The influence of spellings on speech: Are alveolar flaps $/ d /$ or $/ t /$ ? Metalinguistic awareness and beginning literacy, ed. by D. Yaden and S. Templeton, 101-114. Exeter, NH: Heinemann.

D’Emilio, A.L. 1986. La elaboración de alfabetos como tarea interdisciplinaria. Boletin 9. United Nations Educational, Scientific and Cultural Organization. Proyecto Principal de Educación en America Latina y El Caribe.

Downing, Pamela, et al. (eds). 1992. The linguistics of literacy. Amsterdam: John Benjamins.

Dyrud, Lars O. 2001. Hindi-Urdu: Stress accent or non-stress accent? University of North Dakota. (M.A. thesis).

Estrill, Carrie Anne. 1985. The development of tone in Panjabi as evidenced in the poetic alliteration patterns. University of Wisconsin - Madison. (Ph.D. dissertation).

Goldsmith, John A. 1990. Autosegmental and metrical phonology. Oxford: Blackwell.

Grierson, George A. (ed). 1973 (c1903). Linguistic survey of India. Delhi: Motilal Banarsidass. (Vols. 1-11).

Grimes, Barbara F. 2000. Ethnologue: Languages of the world. 14th Edition. Dallas: SIL International.

Gudschinsky, Sarah C. 1973. A manual of literacy for preliterate peoples. Ukarumpa, Papua New Guinea: Summer Institute of Linguistics.

Gussenhoven, Carlos, and Haike Jacobs. 1998. Understanding phonology. London: Arnold.

Hallberg, Calinda E., and Clare F. O'Leary. 1992. Dialect variation and multilingualism among Gujars in Pakistan. Hindko and Gujari, ed. by Calvin R. Rensch, Calinda E. Hallberg, and Clare F. O'Leary, 91-194, 259-305 Islamabad: National Institute of Pakistan Studies and Summer Institute of Linguistics. (Sociolinguistic Survey of Northern Pakistan Vol. 3). 
Hugoniot, Ken, and Dietmar Polster. 1997. A sociolinguistic profile of Eastern Gujari. (unpublished manuscript).

Hussain, Sarmad. 1997. Phonetic correlates of lexical stress in Urdu. Northwestern University. (Ph.D. dissertation).

Kaye, Alan S. 1996. Adaptations of Arabic script. The world's writing systems, ed. by P.T. Daniels and W. Bright, 743-757. Oxford: Oxford University Press.

Khatana, Ram Parshad. 1992. Tribal migration in Himalayan frontiers: Study of Gujar Bakarwal transhumance economy. Haryana, India: Vipin Jain/Vintage Books.

Ladefoged, Peter, and Ian Maddieson. 1996. The sounds of the world's languages. Oxford: Blackwell.

Losey, Wayne E. forthcoming. The Gojri of the Bakarwals: Dialect variation among Gujar pastoralists.

MacEachern, Margaret R. 1997. Laryngeal cooccurrence restrictions. University of California Los Angeles. (Ph.D. dissertation).

Masica, Colin P. 1991. The Indo-Aryan languages. Cambridge: Cambridge University Press.

Mathews, David, and Mohamed Kasim Dalvi. 1999. Teach yourself Urdu. London: Hodder \& Stoughton Ltd.

Mohanan, K.P. 1986. The theory of lexical phonology. Dordrecht: D.Reidel.

Naval, Uday C. 1986. Tones in Panjabi: A reinterpretation. Papers in Linguistics vol.12:152-171. New York: City University of New York.

Nida, E. A. 1964. Practical limitations to a phonemic alphabet. Orthography studies: Articles on new writing systems, ed. by W. Smalley, 22-30. London: United Bible Societies. Originally appeared in The Bible Translator 5:1954.

Ohala, Manjari. 1972. Topics in Hindi-Urdu phonology. University of California Los Angeles. (Ph.D. dissertation).

Ohala, Manjari. 1983. Aspects of Hindi phonology. Delhi: Motilal Banarsidass. 
Parvez, Aslam. 1996. The adaptation of the Perso-Arabic script for Urdu, Panjabi and Sindhi. Monumental Publishers, New Delhi.

Payne, Thomas. 1997. Describing morphosyntax; a guide for field linguists. Cambridge: Cambridge University Press.

Pike, Kenneth L. 1947. Phonemics: A technique for reducing languages to writing. Ann Arbor: U. of Michigan Press.

Pulleyblank, Douglas. 1986. Tone in lexical phonology. Dordrecht: R. Reidel.

Schmidt, Ruth Laila. 1999. Urdu: An essential grammar. London: Routledge.

Shackle, Christopher. 1979. Problems of classification in Pakistan Panjab. Transactions of the Philological Society, 191-210. Oxford.

Sharma, Jagdish Chander. 1982. Gojri grammar. Mysore: Central Institute of Indian Languages. (Grammar Series No. 9).

Sharma, Jagdish Chander. 1979. Gojri phonetic reader. Mysore: Central Institute of Indian Languages. (Phonetic Reader Series No. 19).

Simons, Gary F. 1994. Principles of multidialectal orthography design. Notes on Literacy 20:2. Dallas: Summer Institute of Linguistics.

Spaulding, Frank Charles. 1994. The Gujars of Islamabad. Ohio State University. (Ph.D. dissertation).

Tabouret-Keller, Andrée et al (eds). 1997. Vernacular literacy: A re-evaluation. Oxford: Clarendon Press.

Taylor, Insup, and David R. Olson (eds). 1995. Scripts and literacy: Reading and learning to read alphabets, syllabaries and characters. Dordrecht: Kluwer Academic.

Thikri, M. Aslam Armani, and Wayne E. Losey. 2001. Gojri alphabet primer. Abbottabad: Wayne E. Losey.

Voorhoeve, J. 1964. Some problems in writing tone. Orthography studies: Articles on new writing systems, ed. by W. Smalley, 127-131. London: United Bible Societies. 
Walker, R. 1987. Towards a model for predicting the acceptance of vernacular literacy by minority-language groups. University of California, Los Angeles. (Ph.D. dissertation).

Walter, Steve. 1995. The 'soft' principles of orthography design. (unpublished paper).

Weber, David J. in press. Writing Quechua. Accepted for publication by UCLA: Latin American Studies Center. (This is the English version of Weber, David J. 1994. Ortografía: Lecciones del quechua. Serie Lingüística Peruana 32. Yarinacocha, Pucallpa, Perú: Instituto Lingüístico de Verano.)

Wells, Clarice, and Peter Roach. 1980. An experimental investigation of some aspects of tone in Punjabi. Journal of Phonetics vol. 8:85-89. 